\title{
CARACTERIZAÇÃO AGRONÔMICA DE CRUZAMENTOS DE SOJA TIPO ALIMENTO COM TIPO GRÃO
}

\section{CLAUDIO YUJI TSUTSUMI}

Engenheiro Agrônomo

Orientador: Prof. Dr. NATAL ANTONIO VELLO

Tese apresentada à Escola Superior de Agricultura "Luiz de Queiroz", Universidade de São Paulo, para obtenção do título de Doutor em Agronomia, Área de Concentração: Genética e Melhoramento de Plantas.

PIRACICABA

Estado de São Paulo - Brasil

Junho -2000 
TSUTSUMI, C. Y. Caracterização agronômica de cruzamentos de soja tipo alimento com tipo grão, 200. 158p.

\section{ERRATA}

\begin{tabular}{|c|c|c|c|}
\hline Página & Linha & Onde se lê & Leia-se \\
\hline 46 & 18 & $\ldots \mathbf{R}_{\mathbf{j}} \ldots$ & $\ldots \mathbf{R}_{\mathbf{y} / \mathrm{s}} \ldots$ \\
\hline 46 & 20 & $\mathbf{Y}_{\mathbf{i j k} \mathbf{k}=\ldots}$ & $\mathbf{Y}_{\mathbf{i j l k s}}=\ldots$ \\
\hline 46 & 24 & $\mathbf{R}_{\mathrm{j}}:$ & $\mathbf{R}_{\mathbf{y} / \mathrm{s}}:$ \\
\hline 48 & 6 & $G L_{l l} Q M_{l}$ & $G L_{l} Q M_{l}$ \\
\hline 49 & 19 & $V_{(x y)}=V_{(x)}+V_{(y)}+2 \operatorname{cov}_{(x+y)}$ & $V_{(x+y)}=V_{(x)}+V_{(y)}+2 \operatorname{cov}(x y)$ \\
\hline 55 & 26 & $\begin{array}{l}\ldots \mathrm{NDF}, \mathrm{APF}, \mathrm{APM}, \mathrm{PR}, \% \mathrm{~V} 1, \\
\% \mathrm{~V} 3 \text { e } 5 \% \text { apenas em DAP, ... }\end{array}$ & $\begin{array}{l}\ldots \text { NDF, NDM, DAP, PCS, } \% \text { V1 e } \\
5 \% \text { em PR e } \% V 3, \ldots\end{array}$ \\
\hline 59 & 27 & $\ldots n^{\circ} 9 \ldots$ & $\ldots .^{\circ} 19 \ldots$ \\
\hline 59 & 29 & $\ldots n^{\circ} 19 \ldots$ & $\ldots$ n. ${ }^{\circ} 9 \ldots$ \\
\hline 63 & 4 & 28 das 66 progênies $(42,4 \%)$ & 28 das 66 progênies $(57,6 \%)$ \\
\hline 72 & 15 & $\ldots($ Tabela 15$) \ldots$ & $\ldots($ Tabela 16$) \ldots$ \\
\hline 73 & 18 & $\ldots 20 \% \ldots$ & $\ldots 10 \% \ldots$ \\
\hline 83 & 8 & $\ldots-50 \%<\mathrm{r}<50 \% \ldots$ & $\ldots-100 \%<\mathrm{r}<-50 \% \ldots$ \\
\hline 84 & 13 & ... testemunhas ... & ... correlações ... \\
\hline 100 & 18 & $\ldots$ sete $\ldots$ & ... três ... \\
\hline 135 & 1 & Tabela $10 \ldots$ & Tabela $11 \ldots$ \\
\hline
\end{tabular}

Página linha

Acrescenta-se

$47 \quad 22 \quad$ G: 1 a 37 genótipos;

$60 \quad 17 \quad \ldots 31(55,6 \mathrm{~cm}), \ldots$

$65 \quad 25(67,7 \mathrm{~g} /$ planta $)$ 


\section{Dados Internacionais de Catalogação na Publicação (CIP) DIVISÃO DE BIBLIOTECA E DOCUMENTAÇÃO - Campus "Luiz de Queiroz"/USP}

Tsutsumi, Claudio Yuji

Caracterização agronômica de cruzamentos de soja tipo alimento com tipo grão / Claudio Yuji Tsutsumi. - - Piracicaba, 2000.

$158 \mathrm{p}$.

Tese (doutorado) - Escola Superior de Agricultura Luiz de Queiroz, 2000.

Bibliografía.

1. Alimento vegetal 2. Caracteristica agronômica 3. Cruzamento vegetal 4. Grão 5.

Melhoramento genético vegetal 6 . Progênie vegetal 7. Soja I. Título

CDD 633.34

Permitiala a copia total ou parcial deste documento, desde que citada a fonte -0 autory 
À memória de meus avós,

que vieram a este grande país,

OFEREÇO

Aos meus pais,

que trabalharam a terra,

A minha irmã, Yuri, meu cunhado

Dwight e a minha sobrinha Kiira, DEDICO 


\section{AGRADECIMENTOS}

- Ao Professor Dr. Natal Antonio Vello, pela sua orientação e especialmente pela amizade, apoio e constante incentivo e por sua contribuição na minha formação científica.

- A Escola Superior de Agricultura "Luiz de Queiroz", Universidade de São Paulo, por conceder a oportunidade de realizar o Curso de Pós-Graduação em Agronomia - Área de Concentração: Genética e Melhoramento de Plantas.

- Aos professores do Curso de Pós-Graduação, pelos ensinamentos e atenção dispensada no decorrer do curso, especialmente aos Profs. Drs. Gerhard Bandel, Akihiko Ando e Isaias Olívio Geraldi.

- Ao Departamento de Genética, ESALQ/USP, pela concessão de materiais e instalações.

- Ao CNPq, EMBRAPA, FAPESP, pelo financiamento de projetos de pesquisa durante a fase de desenvolvimento do germoplasma principal avaliado neste trabalho.

- A Capes pela concessão de bolsa de estudos.

- Ao Dr. Hiroshi Nagai, do Instituto Agronômico de Campinas, a quem devo minha iniciação no melhoramento genético.

- Aos amigos, Gilberto K. Yokomizo e Marcos C. Nekatschalow, um agradecimento especial, pela amizade, pelo agradável convívio e pelas constantes práticas esportivas.

- Aos amigos Fábio Pandini e Andréa Mittelmann, pelo constante apoio, confiança, conselhos e principalmente pela amizade e paciência manifestada.

- Aos amigos, Angela Celis de A. Lopes e Maurisrael de M. Rocha, pela amizade constante, apoio e pelas sugestões e correções do texto da tese.

- Às amigas Maria Cândida de A. Lopes e Estela Kaminagakura, pela amizade, apoio e alegre convívio.

- Às amigas Maria Aldete J. da F. Ferreira e Maria Clideana C. Maia, pela amizade e companheirismo.

- Aos amigos do grupo da soja: Alessandra Pereira Fávero, Angela C. A. Lopes, Diego O. Soldini, Edina R. Moresco, Fábio Pandini, Fernando, T. S. Miranda, Gilberto K. 
Yokomizo, Jorge R. Laínez-Mejía, Lafayete L. da Silva, Maria Clideana C. Maia, Maurisrael de M. Rocha, Sandra H. U. Trevisoli, Vanoli Fronza, pela amizade, apoio e companheirismo durante todo o nosso estudo.

- A Alvis H. Adames, José Raulindo Garlindo e Ricardo Yara, pela amizade e constante e alegre convívio.

- Aos amigos do curso, um agradecimento especial a Ana Cláudia C. Badan, Antônio Ismael I. Cardoso, Chirlei Glienke, Edson F. da Silva, João Batista Duarte, Leonardo N. Rosse, Luciana de A. Ribeiro, Luciana S. R. Pinto, Juan Carlos P. Velasquez, Marcelo A. N. Nishikawa, Maria I. Zucchi, Paulo. A. V. Barroso, Patrícia F. Cardoso, Rhainer G. Cardoso, Rogério de M. C. Pinto, Solange R. M. de Andrade, e a todos aqueles que conheci no decorrer do curso.

- Aos funcionários do Setor de Genética Aplicada às Espécies Autógamas, Marcos C. Nekatschalow, Antônio Roberto Cogo e Claudinei Antônio Didoné, um agradecimento pelo apoio nas etapas de campo e de laboratório e pela amizade durante a condução dos trabalhos.

- A todos os funcionários do Departamento de Genética, com especial atenção a Adriana Maria. R. O. Bussi, Antônio de Pádua Gorga, Cândida Vanderléia de Oliveira, Carlos Roberto Macedônio e Neusa Maria S. Rocha, pela amizade e atenção gentilmente cedida.

- Às bibliotecárias Silvana M. Gregório, Aparecida Elizabete S. Silva e Silvana Cristina N. Oliveira pelos gentis préstimos no decorrer do curso.

- E a todos que de maneira direta ou indireta contribuíram para a realização deste trabalho. 


\section{SUMÁRIO}

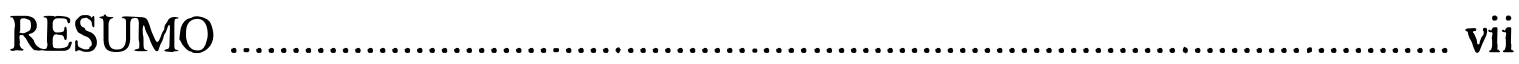

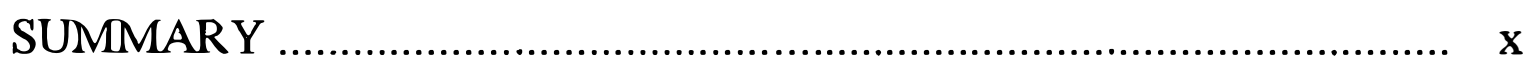

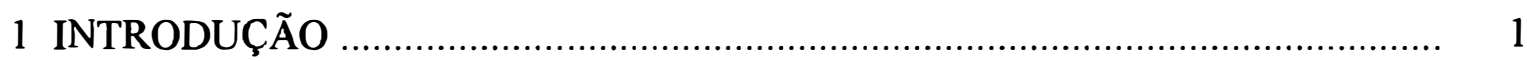

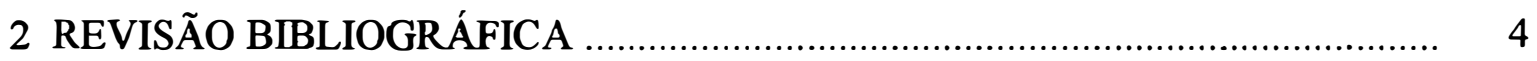

2.1 Considerações gerais ..................................................................................... 4

2.2 Origem, domesticação e introdução da soja no Brasil ..................................... 8

23 Qualidades organolépticas e nutricionais ................................................ 12

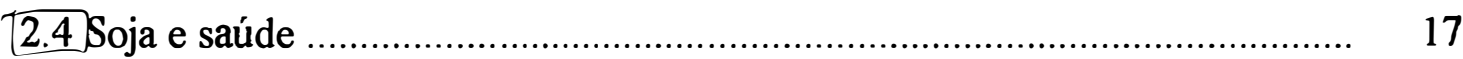

2.4)Qualidade da soja tipo alimento ........................................................... 22

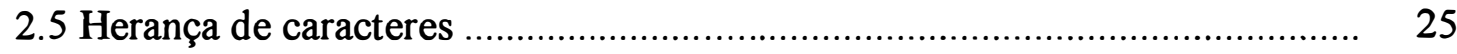

2.5.1 Caracteres da planta ..................................................................... 25

2.5.2 Caracteres de vagem e de semente .................................................. 29

2.6 Correlações entre caracteres ....................................................................... 33

2.7 Interação genótipos $\mathrm{x}$ ambientes ................................................................ 36

3 MATERIAL E MÉTODOS ……................................................................. 40

3.1 Material genético ..................................................................... 40

3.2 Ambiente experimental .................................................................. 41

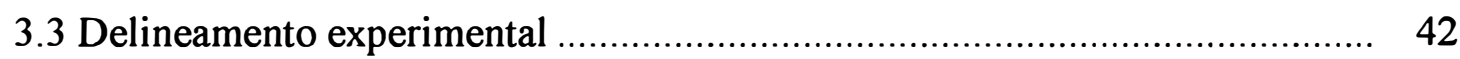

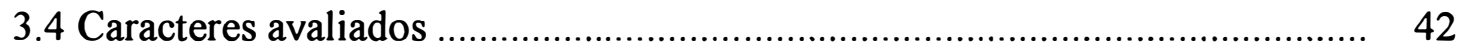

3.4.1 Caracteres qualitativos avaliados ................................................. 42

3.4.2 Caracteres quantitativos avaliados .................................................. 42

3.5 Análises estatístico-genéticas ……...................................................... 45

3.5.1 Médias e variâncias .................................................................. 45

3.5.2 Análise de variância ................................................................. 45

3.5.3 Contribuição de cada fonte de variação na

3.5.4 Correlações genéticas e fenotípicas ...................................................... 48

3.5.5 Agrupamento de Scott-Knott ...................................................... 50

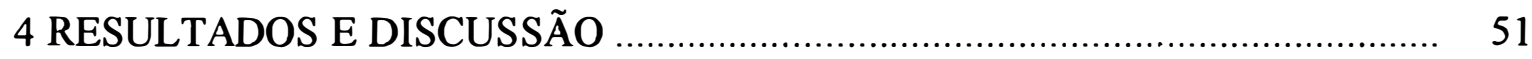

4.1 Considerações iniciais …..................................................................... 51

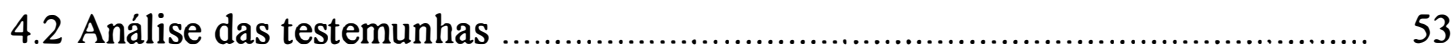

4.3 Análise de variância para os genótipos .................................................... 54

4.3.1 Análise de variância para cada ambiente ........................................... 54

4.3.2 Análise de variância conjunta ........................................................... 55 
4.4 Contribuição de cada fonte de variação

na diversidade total dos dados para cada caráter

4.5 Médias, desvios padrões e desempenho

das progênies em relação às médias das testemunhas

4.5.1 Caracteres relacionados ao ciclo da planta

4.5.2 Caracteres relacionado à altura da planta e ao acamamento

4.5.3 Valor agronômico, produtividade de grãos, vagens e de óleo

4.5.4 Caracteres relacionados ao tamanho das sementes e tipos de vagens

4.6 Comparação de médias e agrupamento das progênies pelo teste de Scott-Knott

4.6.1 Caracteres relacionados ao ciclo da planta

4.6.2 Caracteres relacionado à altura da planta e ao acamamento

4.6.3 Valor agronômico, produtividade de grãos, vagens e de óleo

4.6.4 Caracteres relacionados ao tamanho das sementes e tipos de vagens

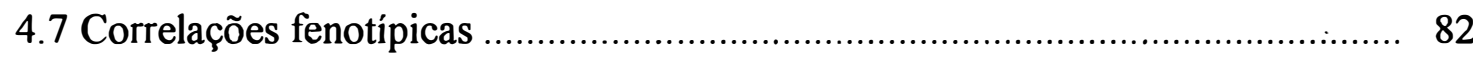

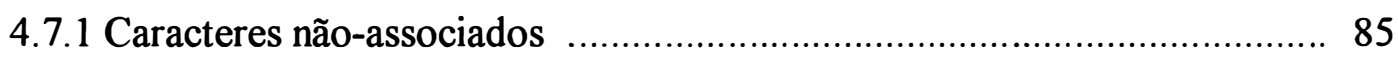

4.7.2 Caracteres associados negativamente …......................................... 88

4.7.3 Caracteres associados positivamente …............................................. 89

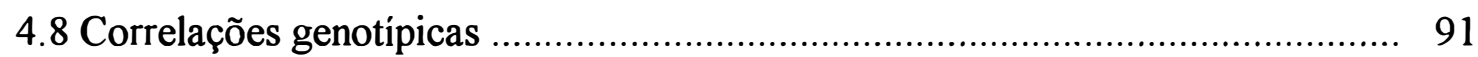

4.8.1 Caracteres não-associados .......................................................... 92

4.8.2 Caracteres associados negativamente ……......................................... 93

4.8.3 Caracteres associados positivamente ................................................ 94

4.9 Seleção de progênies para usos alimentares específicos .................................. 94

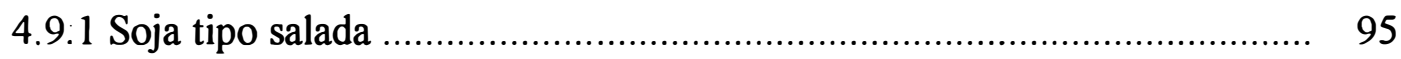

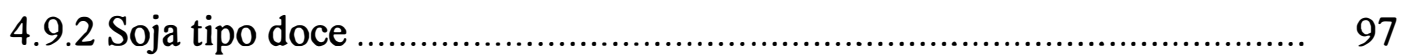

4.9.3 Soja tipo hortaliça ou edamame ..................................................... 98

4.9.4 Soja tipo tofu e extrato ................................................................. 100

4.10 Considerações finais ......................................................................... 101

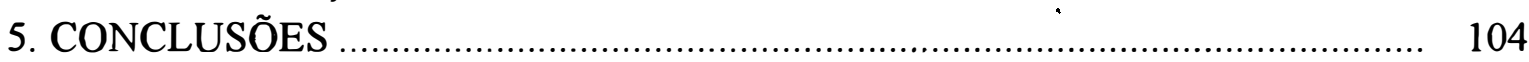

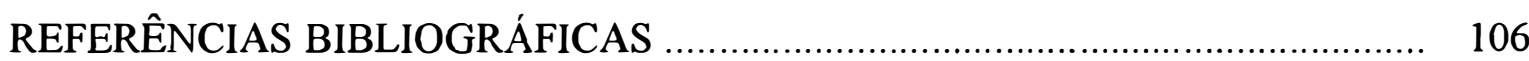

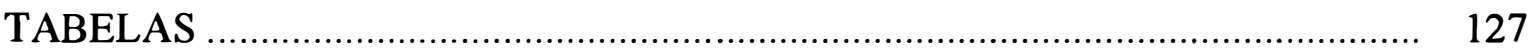

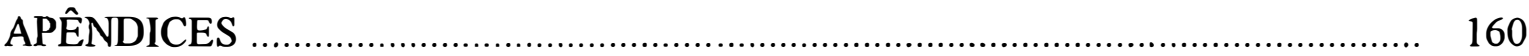




\title{
CARACTERIZAÇÃO AGRONÔMICA DE CRUZAMENTOS DE SOJA TIPO ALIMENTO COM TIPO GRÃO
}

\author{
Autor: CLAUDIO YUJI TSUTSUMI \\ Orientador: PROF. DR. NATAL ANTONIO VELLO
}

\section{RESUMO}

Esta pesquisa teve por finalidade principal a avaliação de progênies originadas de cruzamentos entre parentais exóticos de soja tipo alimento e parentais adaptados tipo grão. Três objetivos específicos foram estabelecidos: a) estimação de correlações entre caracteres importantes para os programas de melhoramento da soja tipo alimento; b) verificação do potencial de seleção das progênies para usos alimentares específicos: salada, doce (kuromame), hortaliça (edamame) e tofu (coalho)/extrato(leite) de soja; c) constatação da possibilidade de selecionar progênies de soja tipo grão para cultivo e ou ampliação da base genética de programas de melhoramento da soja cultivada.

$O$ material genético compreendeu 33 progênies na geração $F_{11: 4}$, préselecionadas na geração $F_{9: 4}$ de 15 cruzamentos de soja. Foram empregadas quatro testemunhas comuns: IAC PL-1, Tamba, Céu Azul e Nimame; estas foram escolhidas devido as suas características apropriadas ao consumo humano direto (cultivares de soja tipo alimento com sementes grandes). A pesquisa foi conduzida em áreas experimentais do Departamento de Genética/ESALQ/USP, em dois locais de Piracicaba: sede ESALQ e Estação Experimental Anhembi, distante cerca de $60 \mathrm{~km}$ da sede ESALQ.

Os experimentos foram conduzidos em condições de campo no delineamento de blocos ao acaso com duas repetições estratificadas em conjuntos com testemunhas comuns. Cada repetição foi formada por dois conjuntos experimentais contendo 16 e 17 progênies e quatro testemunhas em cada um. A parcela experimental foi constituída por três fileiras de três plantas, compreendendo um total de nove covas de plantas individuais espaçadas $0,80 \mathrm{~m}$ entre e dentro de cada fileira; desta forma, a área total da parcela correspondeu a $2,40 \mathrm{~m} \times 2,40 \mathrm{~m}$, ou $5,76 \mathrm{~m}^{2}$. Portanto, foram avaliadas até 36 plantas de 
cada progênie e até 72 plantas de cada testemunha, totalizando 1476 plantas nos dois experimentos.

Os caracteres avaliados foram: número de dias para o florescimento (NDF), altura da planta no florescimento (APF), número de dias para a maturidade (NDM), altura da planta na maturidade (APM), período reprodutivo (PR), diferença na altura da planta durante o período reprodutivo (DAP), acamamento (AC), valor agronômico (VA), largura visual das vagens (LVV), produtividade de grãos (PG), peso de cem sementes maduras (PCS), teor de óleo (\%OL), produtividade de óleo (PO), número total de vagens (NTV), porcentagem de vagens maduras com uma semente (\%V1), porcentagem de vagens maduras com duas sementes $(\% \mathrm{~V} 2)$, porcentagem de vagens maduras com três ou mais sementes (\%V3) e produtividade de vagens (PV).

Os resultados obtidos suportam as seguintes conclusões: a) Várias das progênies superiores em $F_{11: 4}$ já haviam se destacado em gerações anteriores como soja tipo alimento. Algumas progênies também mostraram potencial para cultivo ou uso como parentais em programas de melhoramento de soja tipo grão. b) Existe variabilidade genética remanescente entre as progênies para alguns caracteres, o que viabiliza a obtenção de ganhos futuros por meio de seleção. c) $\mathrm{O}$ local Anhembi mostrou-se mais favorável para a diferenciação da maioria dos caracteres, em relação ao local ESALQ. d) A magnitude e o sinal das correlações entre caracteres não foram influenciados pelas diferenças entre locais, mas foram muito alterados pelos grupos de genótipos (testemunhas e progênies). e) As correlações genotípicas entre caracteres foram superiores às fenotípicas e permitiram o estabelecimento de três níveis de associações: $e_{1}$ ) caracteres não-associados: PR x LVV, PR x PCS, PR x NTV, PR x \%V2, PR x PV, LVV $x$ PG, LVV x \%OL, PG x PCS, PG x \%V1, PCS x \%V1, \%OL x \%V2, NTV x \%V2, NTV $x \% \mathrm{~V} 3, \% \mathrm{~V} 1 \times$ \% $3, \% \mathrm{~V} 2 \times \mathrm{PV}$ e \%V3 x PV; $\mathrm{e}_{2}$ ) caracteres associados negativamente: PR x \%OL, PR x \%V3, LVV x \%V3, PG x \%V3, PCS x \%OL, PCS $x$ $\% \mathrm{~V} 3 \mathrm{e} \% \mathrm{~V} 2 \mathrm{x} \% \mathrm{~V} 3 ; \mathrm{e}_{3}$ ) caracteres associados positivamente: LVV $\mathrm{x} \% \mathrm{~V} 1, \% \mathrm{OL}$ x \%V3 e NTV x PV. f) Houve eficiência na seleção baseada nas classificações de Scott-Knott, nas médias dos caracteres, e nas características específicas mais relevantes para obtenção de quatro tipos de utilização (salada, doce, hortaliça e tofu/extrato de soja). Para uso 
como salada, foram formados dois subgrupos: o subgrupo de sementes amarelas, incluiu quatro progênies: USP98-06002, USP98-06005, USP98-06008 e USP98-06029; e o subgrupo de sementes verdes, envolveu cinco progênies: USP98-06012, USP98-0614, USP98-06020, USP98-06021 e USP98-06034. Para uso como doce, foram selecionadas sete progênies: USP98-06010, USP98-06013, USP98-06017, USP98-06018, USP9806023, USP98-06024 e USP98-06025. Para uso como hortaliça ou edamame, foram formados dois subgrupos; o subgrupo com sementes de hilo e pubescência claros, incluiu uma única progênie: USP98-06009; e no subgrupo de sementes de hilo e/ou pubescência escuros, foram selecionados oito progênies: USP98-06003, USP98-06013, USP98-06017, USP98-06019, USP98-06020, USP98-06021, USP98-06023 e USP98-06031. Para uso como tofu e extrato de soja, a seleção incluiu três progênies: USP98-06001, USP9806008 e USP98-06030. 


\title{
AGRONOMIC CHARACTERIZATION OF CROSSES AMONG FOOD AND GRAIN TYPES OF SOYBEANS
}

\author{
Author: CLAUDIO YUJI TSUTSUMI \\ Adviser: PROF. DR. NATAL ANTONIO VELLO
}

\section{SUMMARY}

This research had as main purpose the evaluation of soybean crosses between exotic of food type parents and adapted grain type parents. Three specific objectives were established: a) estimation of correlations among important characters for the breeding programs of the food type soybeans; b) verification of the potential of selection for the progenies for specific alimentary uses: salad, sweet meat (kuromame), vegetable (edamame) and tofu (curd)/soy extract (milk); c) verification of the possibility of selecting progenies of grain type soybean for cultivation and or amplification of the genetic base of breeding programs of the cultivated soybean.

The genetic material included 33 progenies in the $F_{11: 4}$ generation, preselected in the $\mathrm{F}_{9: 4}$ generation of 15 soy topcrosses. Four common checks were used: IAC PL-1, Tamba, Céu Azul and Nimame; these were chosen due your appropriate characteristics to the direct human consumption, because they are food type soybeans with large seeds. The research was led in experimental areas of the Department of Genetics/ESALQ/USP, in two localities of Piracicaba: ESALQ and Anhembi Experimental Station, distant about $60 \mathrm{~km}$ of the ESALQ.

The experiments were led in field conditions in the complete randomized blocks with two replications. Each replication was formed by two experimental sets containing 16 and 17 progenies and four checks in each one. The experimental plots was constituted by three rows of three plants, understanding a total of nine hills of individual plants spaced $0.80 \mathrm{~m}$ among and inside of each row, thus, the total area of the plot was $2.40 \mathrm{~m} \times 2.40 \mathrm{~m}$, or $5.76 \mathrm{~m}^{2}$. Therefore, they were evaluated until 36 plants of each progeny and 72 plants of each check, totaling 1476 plants in the two experiments. 
The evaluated characters were: time do flowering (NDF), plant height at flowering (APF), time to maturity (NDM), plant height at maturity (APM), reproductive period (PR), difference in the plant height during the reproductive period (DAP), lodging (AC), agronomic value (VA), pod width by visual score (LVV), mature seed yield (PG), one hundred seed weight (PCS), oil content (\%OL), oil yield (PO), total number of pods (NTV), percentage of mature pods with one seed $(\% \mathrm{~V} 1)$, percentage of mature pods with two seeds (\%V2), percentage of mature pods with three or more seeds (\%V3) and mature pod yield (PV).

The obtained results support the following conclusions: a) Several of the superior progenies in $\mathrm{F}_{11: 4}$ there were already outstanding in previous generations. Some progenies also presented potential for cultivation and or use as parents in breeding programs of grain type soybeans. b) Remaining genetic variability exists among the progenies for some characters, what makes possible to obtain additional genetic gain through selection. c) The Anhembi locality was shown more favorable for the differentiation of most of the characters, relatively to the ESALQ locality. d) The magnitude and the sign of the correlations among characters were not influenced by the differences among localities, but they were very altered by the genotypes groups (checks and progenies). e) The genotypic correlations among characters were superior to the phenotypic correlations and they allowed the establishment of three levels of associations: $e_{1}$ ) not associated characters: PR $\times$ LVV, PR $\times$ PCS, PR $\times$ NTV, PR $\times$ \%V2, PR x PV, LVV x PG, LVV x \%OL, PG x PCS, PG x \%V1, PCS x \%V1, \%OL x \%V2, NTV $x \% \mathrm{~V} 2, \mathrm{NTV} \times \% \mathrm{~V} 3, \% \mathrm{~V} 1 \times \mathrm{\% V} 3, \% \mathrm{~V} 2 \times \mathrm{PV}$ and \%V3 $x \mathrm{PV} ; \mathrm{e}_{2}$ ) negatively associated characters: $\mathrm{PR} x \% \mathrm{OL}, \mathrm{PR} \times \mathrm{\% V} 3, \mathrm{LVV} \times \mathrm{\% V} 3, \mathrm{PG} \times \mathrm{\% V} 3, \mathrm{PCS} \times \mathrm{\% OL}$, PCS $x \% V 3$ and $\% V 2 x \% V 3 ; e_{30}$ positively associated characters: LVV $x \% V 1, \% O L x$ $\% \mathrm{~V} 3$ and NTV $x$ PV. $f$ ) There was efficiency in the selection based on the classifications of Scott-Knott, in the means of the characters, and in the more important specific characteristics for obtaining of four soybean food types (salad, sweet MEAT, vegetable and tofu/extract). For use as salad, two subgroups were formed; the subgroup with yellow seeds, included four progenies: USP98-06002, USP98-06005, USP98-06008 and USP9806029; and the subgroup with green seeds, involved five progenies: USP98-06012, 
USP98-0614, USP98-06020, USP98-06021 and USP98-06034. For use as sweet MEAT, seven progenies were selected: USP98-06010, USP98-06013, USP98-06017, USP9806018, USP98-06023, USP98-06024 and USP98-06025. For use as vegetable or edamame, two subgroups were formed: the subgroup with clear color of hilum seed and pubescence, included an unique progeny: USP98-06009; and in the subgroup of dark colored hilum and/or pubescence, eight progenies were selected: USP98-06003, USP9806013, USP98-06017, USP98-06019, USP98-06020, USP98-06021, USP98-06023 and USP98-06031. For use as tofu and extract, the selection included three progenies: USP98-06001, USP98-06008, and USP98-06030. 


\section{INTRODUÇÃO}

A soja [Glycine max (L.) Merrill] representa a segunda maior cultura em produção de grãos no Brasil, sendo superada apenas pelo milho, atingindo atualmente mais de 30 milhões de toneladas/ano, apresentando, assim, grande importância sócioeconômica para o país.

O óleo, que representa $20 \%$ dos grãos de soja, e seus derivados (gordura hidrogenada, margarina) são amplamente aceitos pelo consumidor brasileiro e representam mais de $70 \%$ do total de lipídeos. No entanto, a fração protéica, que representa $40 \%$, e seus derivados, tem uso restrito mais como farelo para ração animal.

Os alimentos derivados da soja têm surgido sob as mais diversas formas: "in natura"; semi-cozida; extrato (leite) de soja aromatizado; proteína vegetal texturizada (PVT ou carne de soja); processada junto a outros produtos, em embutidos, biscoitos, bolachas e sopas; coalho de soja (tofu); molho de soja fermentado (shoyu); grãos fermentados (natto); pasta de soja fermentada (miso); broto.

$\mathrm{O}$ uso da soja como alimento direto é tradicional nos países orientais, principalmente China, Japão, Coréia e Taiwan. A soja usada diretamente no consumo humano deve ter características especiais: maior teor e melhor qualidade de proteína, menor teor e melhor qualidade de óleo, sabor adocicado lembrando o de nozes, alto teor de carboidratos, ausência ou menor produção de odores desagradáveis, ausência ou reduzido teor de fatores antinutricionais (Carrão-Panizzi, 1989; Vello, 1992a).

No Brasil, de acordo com Vello (1992a) a soja pode ser classificada em dois grupos principais: tipo grão e tipo alimento. A soja tipo grão apresenta sementes de tamanho médio, representado pelo peso de cem sementes (PCS) entre 10 e $19 \mathrm{~g}$, sendo 
cultivada principalmente para atender às indústrias brasileira e estrangeira de farelo e óleo. A soja tipo alimento apresenta duas categorias: a) sementes pequenas, com PCS menor que $10 \mathrm{~g}$, destinadas ao consumo em forma de brotos e de "natto" (fermentado); b) sementes grandes, com PCS igual ou maior que $20 \mathrm{~g} / 100$ sementes. A soja com sementes grandes tem os seguintes usos principais: $b_{1}$ ) soja hortaliça (vegetable soybean ou edamame), utilizada para consumo humano direto na forma de vagens imaturas; $b_{2}$ ) soja doce (kuromame), compreendendo genótipos com sementes grandes, de tegumento preto e consumidos na forma de grãos maduros; $b_{3}$ ) soja salada, para preparação de saladas, com sementes maduras e tegumento de coloração clara (amarela, verde ou variegada); $b_{4}$ ) tofu (coalho) e extrato (leite).

Recentemente, vem surgindo no Brasil uma nova categoria de produtores de soja tipo alimento com sementes grandes para atender ao interesse brasileiro crescente de uso na alimentação humana direta e para exportação para países orientais e, também, para os Estados Unidos e a Austrália.

A soja tipo alimento é cultivada em pequena escala, sendo que, atualmente, está havendo um aumento da área de cultivo nos Estados Unidos e no Canadá. Estão sendo desenvolvidos cultivares adaptados para uso doméstico e exportação para o Japão, onde a produção não atende ao consumo interno. No Brasil ,pesquisas com soja tipo alimento estão sendo desenvolvidas por diversas instituições como a ESALQ/USP - Piracicaba, UFV - Viçosa, CNPSo/EMBRAPA - Londrina e UEL - Londrina, visando desenvolver cultivares com tamanho grande de grãos (para usos em tofu, vegetais, alto teor de proteínas ou isento de lipoxigenases) e com sementes pequenas (para natto e broto de soja).

A pesquisa proposta nesta tese teve por finalidade principal a avaliação de progênies (geração $F_{11: 4}$ ) originadas de cruzamentos entre parentais exóticos tipo alimento e parentais adaptados tipo grão, desenvolvidos pelo programa de ampliação da base genética do germoplasma e melhoramento da soja do Setor de Genética Aplicada às Espécies Autógamas, do Departamento de Genética/ESALQ/USP. Três objetivos específicos foram estabelecidos: a) estimação de correlações entre caracteres importantes 
para os programas de melhoramento da soja tipo alimento; b) verificação do potencial de seleção das progênies para usos alimentares específicos: salada, doce (kuromame), hortaliça (edamame) e tofu (coalho)/extrato(leite) de soja; c) constatação da possibilidade de selecionar progênies de soja tipo grão para cultivo e ou ampliação da base genética de programas de melhoramento da soja cultivada. 


\section{REVISÃO BIBLIOGRÁFICA}

\subsection{Considerações gerais}

A produção de soja no mundo atingiu em 1999 a ordem de 154.323.115 toneladas de grãos, dos quais, 37.809.153 toneladas foram comercializadas no mercado intemacional (FAO, Internet ).

Os maiores compradores de grãos de soja são a Europa, China, Japão e México; sendo os Estados Unidos, Brasil, Argentina e Paraguai, os principais exportadores mundiais (FAO, Internet).

Com uma produção estimada de 31.574.324 toneladas para a safra 99/2000, o Brasil é o segundo maior produtor mundial de soja, antecedida apenas pelos Estados Unidos (IBGE, Internet; FAO, Internet).

A produção de soja, cerca de 13 milhões de toneladas anuais na China e 187 mil toneladas anuais no Japão, em 1999, é incapaz de atender à demanda destes países. Atualmente, a China é o maior importador mundial seguido pelo Japão, respondendo, respectivamente, por um volume de cerca de 5.637.950 toneladas e de 5.056.966 toneladas (FAO, Internet).

Os mercados chinês e japonês podem ser considerados altamente promissores, tanto pela alta dependência destes países em relação ao consumo como pela regularidade da demanda.

O mercado japonês de soja, entretanto, apresenta peculiaridades às quais os países exportadores precisam ajustar-se. Enquanto a soja, para os povos ocidentais destina-se quase que unicamente à produção de óleo vegetal e farelo, para os povos orientais, boa parte dessa semente é destinada à industria de alimentos típicos de 
consumo diário, por exemplo: edamame (soja imatura), tofu (coalho de soja), miso (pasta de soja fermentada), shoyu (soja fermentada líquida), natto (soja fermentada), daizu-nomoyashi (broto de soja), extrato (leite) de soja, entre outros. Assim, as exigências de padrões de qualidade, sustentadas pelos importadores japoneses, especialmente pelas indústrias de produtos alimentícios típicos, são muito rígidas (Miyasaka \& Araújo, 1973, Wang et al., 1979). No Japão, devido a recente competitividade na importação de outras sementes oleaginosas, e do declínio do consurno do arroz e do número de produtores de leite, resultaram num declínio na demanda de alimentos à base de soja. Com isso, há uma tendência recente da pesquisa e da indústria de soja para fazer um "novo" alimento ou material da soja (Noguchi, 1999).

A soja para consumo imaturo é uma das mais importantes fontes de proteína no Japão. A demanda estimada de soja imatura para suprir o mercado é de aproximadamente 160.000 toneladas. Em 1991, a soja imatura foi plantada em 14.000 ha, produzindo 65.300 toneladas de produto fresco, num valor aproximado de US\$ 409 milhões. Em 1993, o Japão importou 51.250 toneladas de soja imatura congelada avaliada em mais de US\$100 milhões. Aproximadamente $75 \%$ da importação de soja imatura congelada é originária de Taiwan e $22 \%$ da China. O restante (3\%) provêm da Tailândia, Estados Unidos e Coréia do Sul. Estes países suprem o mercado japonês, principalmente, de março a maio, quando pode atingir preços de até US\$ 6,00/Kg (Nguyen, Internet).

Estatísticas mostram que a produção do Japão e de Taiwan não suprem o mercado consumidor do início de janeiro até março com um preço razoável; com isso, o Japão é forçado a procurar outros países para suprir uma demanda existente de aproximadamente 10.000 toneladas, com um valor aproximado de US\$25 milhões de toneladas (Nguyen, Internet).

$\mathrm{Na}$ China, a maior parte da soja é consumida na forma de óleo enquanto o farelo é destinado à alimentação animal. A soja é processada também para consumo humano na forma de tou fu (coalho de soja), huang tou ya (broto de soja), mao tou (soja imatura), além de produtos como shoyu e miso. (Wang et al., 1979; Jian, 1984). Os 
principais cultivares incluem: Sanyuuewang na província de Zhejiang; Liuyueba nas províncias de Hefei, Wushi e Hangzhou; Baimaoliuyuewang e Gaqingdou próximo a Nanking; e Jiangyoudou em Shanghai. Numerosos cultivares locais ainda são cultivados, particularmente em Sahanghai e Jiangsu (Guan, citado por Konovsky et al., 1994).

$\mathrm{Na}$ Coréia do Sul, a soja é a terceira cultura granífera em área plantada ficando atrás apenas do arroz e da cevada. Os produtos de soja como tubu (coalho de soja), pot kong (soja imatura), miso, shoyu, natto e moyashi de soja são considerados produtos básicos na alimentação dos sul-coreanos (Hong et al., 1984; Konovsky et al., 1994).

Representantes de indústrias japonesas, por ocasião do Simpósio sobre Soja promovido em Tóquio pela JETRO (Japan External Trade Organization) em 1973, declararam que os cultivares de soja colocados pelo Brasil no mercado internacional deixam muito a desejar no que se refere à utilização em indústrias de alimentos típicos (Miyasaka \& Araújo, 1973).

No Ocidente a soja tem uso indireto na alimentação humana, principalmente na forma de proteína vegetal texturizada (PVT), farinha integral e desengordurada e lecitina, entrando na constituição de alimentos como: margarinas, embutidos (lingüiça, salsicha), hambúrgueres, chocolates, massas, biscoitos e pães (Vello, 1992a).

Tem ocorrido um aumento mundial no interesse pela soja de sementes grandes, principalmente do tipo alimento, cujas produções têm sido incrementadas em escala comercial principalmente na Argentina, Austrália, Israel, Mongólia, Nova Zelândia, Taiwan e Tailândia; aumentos menores de produção têm ocorrido na Alemanha, Butão, Brasil, Grã-Bretanha, Chile, França, Filipinas, Índia, Indonésia, Malásia, Nepal, Singapura e Sri Lanka (Konovsky \& Lumpkim, 1990).

Apesar da grande produção brasileira, o mercado consumidor de soja é bastante restrito, destinando-se a maior parte da produção às indústrias de extração de óleo e processamento de margarinas, que compõem mais de $70 \%$ do total de consumo de lipídeos dos brasileiros; já em relação ao farelo (fração protéica), destinado à alimentação 
animal, $30 \%$ permanece no Brasil e $70 \%$ é exportado. Neste aspecto, o Brasil se comporta de maneira adversa em relação ao mercado internacional e dos outros países exportadores do complexo soja, os quais comercializam basicamente grãos (IBGE, Internet).

Apresentada como um produto alternativo, de baixo custo, que poderia substituir alimentos profundamente enraizados no hábito alimentar brasileiro, como o leite (leite de soja); o feijão (feijão de soja); a carne (carne de soja); a introdução da soja na alimentação brasileira já estava fadado ao fracasso, uma vez que essa leguminosa possui características organolépticas próprias e perceptíveis nos seus produtos derivados. Quando apresentada como um alimento básico, às dificuldades naturais da introdução da soja e derivados na alimentação dos povos ocidentais, inclui-se o fato de não se ter disponíveis no Brasil, cultivares especiais para consumo humano (Azevedo, 1987).

$\mathrm{Na}$ verdade, este fato é perfeitamente compreensível, uma vez que a soja brasileira sempre foi desenvolvida e melhorada para atender ao mercado de produção de óleo comestível e de farelo e, assim, os pesquisadores nacionais, ainda não se preocuparam em melhorar as características culinárias e organolépticas. Programas deste tipo têm importância atual, pois quando a soja se destina à alimentação humana, características organolépticas como sabor, textura e aparência são atributos de importância, vindo determinar a sua aceitação.

Os cultivares de soja são classificados por Vello (1992b) em duas classes principais em função do tamanho das sementes e da categoria comercial a que se destinam; soja tipo grão (10 a $19 \mathrm{~g} / 100$ sementes), direcionada à industria de óleo e farelo; soja tipo alimento, para consumo humano direto. Esta última divide-se em duas subclasses: soja de sementes pequenas $(<10 \mathrm{~g} / 100$ sementes maduras), consumida na forma de broto e de natto e soja de sementes grandes ( $\geq 20 \mathrm{~g} / 100$ sementes); nesta última subclasse está incluída a soja tipo hortaliça, ou vegetal ou edamame, que é cultivada realmente como hortaliça, colhida na fase imatura, cozida em salmoura e consumida principalmente como tira-gosto. Yokomizo (1999) adiciona outras duas subclasses de soja de sementes grandes; a soja tipo salada, consumida da fase de sementes maduras, 
cozidas e temperadas; e a soja tipo doce, também consumida na fase de sementes maduras, cozidas no vapor e adoçadas para o consumo. No Brasil, o consumo da soja tipo alimento é feito quase que exclusivamente pelas colônias orientais e de seus descendentes, principalmente na forma de edamame, natto, miso, tofu, e shoyu.

O número de cultivares de soja existentes no mundo é de centenas e, dentre estas, existem as que são cultivadas visando a alimentação humana, principalmente no Oriente.

Nos Estados Unidos e no Canadá a soja tipo alimento é cultivada em pequena mas significativa escala, com tendência de aumento da área de cultivo. Cultivares adaptados para uso doméstico e exportação para o Japão, estão sendo desenvolvidos em 16 instituições públicas. Até 1999, foram desenvolvidos e lançados no comércio 53 cultivares tipo alimento com sementes de tamanho grande (para uso como edarname, tofu, ou alto teor de proteína) e 35 cultivares com sementes pequenas (para natto ou brotos de soja) (Bernard, 1999).

No Brasil, a implantação de um programa a longo prazo de melhoramento genético que produza cultivares do tipo alimento, de maneira a associar boas características de cultivo com boas características organolépticas e nutricionais, trará perspectivas de abertura de novos mercados de exportação e possibilidade de melhorar a aceitação da soja na mesa do brasileiro, fato altamente desejável, dado o excelente valor nutricional e baixo custo da mesma.

\subsection{Origem, domesticação e introdução da soja no Brasil}

A existência da soja na forma comestível data de vários milênios e se prende à própria origem do povo chinês. Segundo Ying \& Grandvoinnete, citados por Miyasaka (1958), sua existência é mencionada há 5.000 anos, com base na descrição da planta de soja encontrada na obra médica de Che Non escrita a 3.000 A.C.

O seu cultivo foi bastante significativo na China antiga a ponto de se tomar a base de sua alimentação. Começou a se espalhar pela Ásia começando pela Coréia e depois o Japão em épocas muito remotas (Kono, 1986). Existem grandes possibilidades 
da soja ter sido introduzida inicialmente apenas como uma importante erva medicinal e, posteriormente, como alimento (Gotoh, 1984). Até que no século XVII se espalhou para outras regiões da Ásia, tais como a Índia, Ceilão, Tailândia, etc. (Piper \& Morse, 1923).

Segundo Piper \& Morse (1923), nos Estados Unidos a primeira referência sobre o comportamento da soja na região da Pensilvânia foi feita por Mease em 1804.

No Brasil a mais antiga referência encontrada na literatura foi a experiência feita na Bahia em 1882 por Gustavo D’Utra (1882). Em São Paulo, Daffert (1892) fez as primeiras observações sobre soja no Instituto Agronômico de Campinas. A soja chegou também com os primeiros imigrantes japoneses que chegaram em Santos em 1908. Contrariamente, Reis (1956) afirma que a soja foi introdurida pela primeira vez no Brasil através do Rio Grande do Sul, em 1914, pela Escola Superior de Agronomia e Veterinária da Universidade Técnica do Rio Grande do Sul.

Os materiais coletados em colônias japonesas no Brasil foram trazidas do Oriente, direta e casualmente, por imigrantes para consumo próprio na preparação de comidas típicas (Kiihl et al., 1971).

A partir de 1936, o Instituto Agronômico de Campinas formou um banco de germoplasma a partir de material recebido dos Estados Unidos e de material coletado na colônia japonesa radicada no Brasil. Estes foram avaliados e lançados como cultivares, por exemplo: Acadian, Pelican (Pelicano), Yelnando, Valstate, etc., de origem americana e Abura, Mojiana, Aliança, Aliança Preta, etc., originários da colônia japonesa. Estes foram utilizados como parentais adaptados em cruzamentos que resultaram em diversos cultivares: IAC-1, IAC-2, Santa Rosa e Industrial, entre outros (Tabela 1) (Kiihl et al., 1971). 
Tabela 1. Características de alguns cultivares lançados pelo Instituto Agronômico de Campinas na década de 50, através de materiais coletados em colônias japonesas no Brasil.

\begin{tabular}{lccc}
\hline $\begin{array}{c}\text { Nome do } \\
\text { cultivar }\end{array}$ & $\begin{array}{c}\text { Ano de } \\
\text { Lançamento }\end{array}$ & Cor da Semente & $\begin{array}{r}\text { Peso de cem sementes } \\
\text { (PCS) }\end{array}$ \\
\hline Abura & 1935 & Amarela & $17,5 \mathrm{~g}$ \\
Mojiana & 1951 & Amarela & $25,0 \mathrm{~g}$ \\
Aliança & 1953 & Amarela & $26,5 \mathrm{~g}$ \\
Aliança Preta & 1953 & Preta & $26,5 \mathrm{~g}$ \\
Paraná Tardia & 1953 & Amarela & $27,0 \mathrm{~g}$ \\
Nova Granada & 1953 & Amarela & $26,0 \mathrm{~g}$ \\
Araçatuba & 1956 & Amarela & $28,0 \mathrm{~g}$ \\
Santa Maria & & Preta & - \\
Cotia & 1956 & Amarela & $23,5 \mathrm{~g}$ \\
\hline
\end{tabular}

Fonte: Kiihl et al. (1971); Miyasaka (1958).

O cultivar IAC-1, embora tenha sido desenvolvido especificamente como soja tipo grão, é muito apreciado pelos consumidores japoneses dada a sua relativa produtividade e aspecto culinário - rápido cozimento e elevado teor de açúcar $(13,38 \%)$ - sendo produzido na região da Alta Mogiana - SP (Miranda et al., 1977).

O Instituto Agronômico de Campinas lançou o cultivar IAC-Santa Maria702, maior teor de proteína, menor teor de ácido linolênico, casca fina e aderente, sementes de tamanho pequeno (10 a $12 \mathrm{~g} / 100$ sementes) e de coloração preta, que quando cozidas se assemelham ao feijão (Miranda, 1992).

Além do Instituto Agronômico de Campinas, outras instituições e empresas comerciais utilizaram soja tipo alimento como parentais em programas de melhoramento envolvendo hibridação para desenvolver cultivares de soja tipo grão e em alguns casos cultivares do tipo alimento (Tabela 2). 
Tabela 2. Alguns cultivares desenvolvidos no Brasil com a utilização de cultivares de soja do tipo alimento cruzadas com soja tipo grão.

\begin{tabular}{lcccc}
\hline $\begin{array}{c}\text { Nome do } \\
\text { cultivar }\end{array}$ & $\begin{array}{c}\text { Ano de } \\
\text { Lançamento }\end{array}$ & Instituição & $\begin{array}{c}\text { Parental tipo } \\
\text { alimento }\end{array}$ & $\begin{array}{c}\text { Parental tipo } \\
\text { grão }\end{array}$ \\
\hline IAC-1 & 1965 & IAC & Aliança Preta & Palmetto \\
IAC-2 & 1967 & IAC & Aliança Preta & Yelmando \\
IAC-4 & 1975 & IAC & IAC-2 & Hardee \\
Industrial & 1965 & IAC & Mojiana & La 41-1219 \\
Pérola & 1980 & IPAGRO & Industrial & Hood \\
UFV-Araguaia & 1981 & UFV & IAC-2 & Hardee \\
UFV-2 & 1973 & UFV & IAC-2 & Hardee \\
UFV-4 & 1977 & UFV & IAC-2 & Mineira \\
BRS 155 & 1999 & CNPSo & Paraná & PI 157.440 \\
\hline
\end{tabular}

Fonte: Kiihl et al. (1971); Miyasaka (1958); Sediyama et al.(1981).

Em 1999, o Centro Nacional de Pesquisa de Soja - EMBRAPA Soja desenvolveu o cultivar BRS-155 com características para processamento de natto, sementes de tamanho pequeno ( $13 \mathrm{~g} / 100$ sementes) e baixos teores de isoflavonóides. Este cultivar produziu natto de boa qualidade, com textura adequada e sabor igual aos de dois cultivares testados, um americano e outro brasileiro, obtidas de companhias comerciais brasileiras (Carrão-Panizzi et al., 1999).

Segundo Sediyama ${ }^{1}$, comunicação pessoal,, o cultivar IAC-Foscarin-31, soja do tipo grão, está sendo produzido no oeste do Estado de São Paulo e utilizado como soja tipo edamame e comercializado na cidade de São Paulo na comunidade oriental com grande aceitação.

\footnotetext{
${ }^{1}$ Sediyama, T. (Universidade federal de Viçosa), Comunicação pessoal, 1999.
} 


\subsection{Qualidades organolépticas e nutricionais}

O sabor característico da soja e produtos derivados, comumente identificado como "cru", "verde", "feijão verde", amargo e adstringente, tem sido urn dos principais obstáculos ao consumo direto desses alimentos pelos povos ocidentais (Rackis et al., 1970; Buckle, 1981; Okubo et al., 1992).

Esse sabor característico e desagradável é proveniente da interação de uma grande variedade de componentes individuais de "sabor estranho" que derivam tanto dos componentes químicos do grão integral cru, como do efeito do processamento e condições de estocagem (Watanabe \& Kishi, 1984; Okubo et al., 1992). Estes componentes apresentam sabor desagradável com relação aos padrões de palatabilidade dos ocidentais, comprometendo sobremaneira, suas propriedades organolépticas e diminuindo sua aceitabilidade (Rackis et al., 1972).

Buckle (1981) caracteriza dois tipos de problemas relacionados com o sabor desagradável da soja e derivados: o primeiro se refere à natureza e intensidade dos componentes individuais de sabor estranho, enquanto que o segundo diz respeito à ausência de um sabor atrativo própri o. Isolar e identificar componentes de sabor, tem sido exaustivo campo de trabalho para muitos pesquisadores, que para tanto, aliam aos métodos físicos, químicos e físico-químicos de isolamento e identificação e métodos sensoriais para a caracterização dos componentes isolados.

Fujimaki et al., citados por Smith \& Circle (1972), isolaram e identificaram trinta componentes que contribuem positivamente para o sabor característico do grão de soja cru. Dos componentes identificados (álcoois, alcanos, aldeídos aromáticos, ácidos graxos, ácidos fenólicos, aminas e ésteres), são os álcoois os que se encontram em maior concentração, notadamente o $\mathrm{n}$-hexanol, o qual contribui de forma mais significativa para a presença do sabor identificado como "feijão cru" na soja (Fujimaki et al., citados por Smith \& Circle, 1972; Watanabe \& Kishi, 1984).

Okubo et al. (1992) relataram a existência de diferentes compostos que contribuem para o sabor indesejável da soja e seus derivados, como os nove ácidos fenólicos presentes no farelo de soja, o etil- $\alpha$-D-galactopiranosídeo e o L-triptofano, 3 
fosfatidilcolinas oxidadas, isoflavonas e saponina I de soja. Em testes de características organolépticas da soja, as saponinas e as isoflavonas contribuíram acentuadamente para um sabor desagradável. O sabor característico das saponinas e isoflavonas de soja é desagradável, sendo respectivamente amargo e adstringente. As saponinas do grupo A mostraram o sabor mais desagradável entre todas as frações obtidas.

Soluções de saponina de soja foram comparadas com solução de cafeína (amargo), pois as saponinas apresentam sabor desagradável com amargor; similarmente soluções com componentes das isoflavonas foram comparadas com uma solução de naringina (adstringente). As saponinas de soja do grupo A possuem o sabor desagradável mais forte entre os glicosídeos da soja. Enquanto as saponinas da soja mostram uma tendência a enfraquecer em sabor desagradável como resultado da decomposição de suas agliconas, as isoflavonas mostram uma tendência reversa, e são muito mais fortes em sabor decompostas do que suas agliconas (Okubo et al., 1992).

Os ácidos fenólicos, notadamente os ácidos siríngico e clorogênico, embora presentes na soja em baixas concentrações, concorrem para o sabor rançoso, amargo e adstringente (Smith \& Circle, 1972).

Grande parte dos componentes de odor e sabor desagradáveis da soja decorrem da ação da enzima lipoxigenase sobre os componentes lipídicos. A lipoxigenase catalisa como reação primária, a hidroperoxidação de certos ácidos graxos insaturados e vários lipídeos polinsaturados contendo resíduos de cis-cis-1,4-pentadieno. Os produtos dessa reação se decompõem formando aldeídos e álcoois, já reportados como os maiores componentes do sabor de "feijão verde", "feijão cru" e gosto amargo na soja e produtos derivados (Azevedo, 1987).

Embora a enzima lipoxigenase e lipídeos estejam presentes no grão de soja, desde que o tecido não seja rompido, nenhum odor ou sabor estranho é desenvolvido. Entretanto, processos mecanizados por que passa a soja durante a colheita, transporte e armazenamento, concorrem para a lesão dos tecidos do grão, liberando tanto a enzima como o substrato, levando ao desenvolvimento dos componentes de odor e sabor intrínsecos à soja (Rackis et al., 1970; Della Modesta \& Garrutti, 1982). 
Testes sensoriais realizados com produtos de soja preparados com $0,25,50$, 75 e $100 \%$ de grãos levemente danificados, indicaram que um plantel de provadores não treinados podia facilmente detectar o sabor de "feijão verde" no produto preparado com $25 \%$ de grãos levemente danificados (Ferrier, 1975).

Devido aos significativos problemas decorrentes da ação da lipoxigenase na soja, muitos estudos têm sido realizados e em decorrência, tem sido reportado, para a maioria dos cultivares, a presença de pelo menos três isoenzimas lipoxigenases: lipoxigenase $1\left(L x_{1}\right)$, lipoxigenase $2\left(L x_{2}\right)$ e lipoxigenase $3\left(L x_{3}\right)$. Entretanto, cultivares de soja lipoxigenase mutantes, isto é, com ausência de uma ou mais isoenzimas, também têm sido identificadas. Kitamura (1984), admite ser possível, através de melhoramento genético, diminuir extremamente os níveis de lipoxigenase nos cultivares de soja, de forma a se obter novas linhagens onde a ação enzimática seja geneticamente reduzida, com a conseqüente diminuição do desenvolvimento de odores e sabores desagradáveis, obtendo-se assim sementes de odores e sabores mais brandos.

Os alelos que causam a ausência de $L x_{1}, L x_{2}$ e $L x_{3}$ de grãos de soja são recessivos (Hildebrand \& Hymowitz, 1981). Estudos genéticos mostraram que os alelos $L x_{1} l x_{1}$ e $L x_{3} l x_{3}$ são transferidos geneticamente como genes simples e não ligados (Kitamura et al., 1983). Entretanto, os genes que codificam para $l x_{1}$ e $l x_{2}$ são ligados, o que tem dificultado a obtenção do mutante duplo $l x_{1} l x_{1}$ e $l x_{2} l x_{2}$ (Moreira et al., 1991).

$\mathrm{Na}$ análise de atividade de $L x_{1}$ e $L x_{3}$, o cultivar Doko apresentou valores muito altos, enquanto que o cultivar FT-2 apresentou valores médios a baixos, assim é possível a formação de grupos estatisticamente diferentes (Barros et al., 1984). Esta variação, possivelmente, é devida à presença de genes reguladores agindo na atividade das lipoxigenases. Hamond et al. (1992) e Kitamura et al. (1983), ao contrário, não encontraram evidências da presença de genes modificadores ou interações epistáticas com relação às lipoxigenases $L x_{l}$ e $L x_{3}$ dos grãos de soja.

Em cruzamentos realizados em soja foi observada uma segregação na geração $F_{2: 3}$ de 1:14:1, no conteúdo de ácido linolênico em óleo de soja que é associado com odor e outras características, levantando-se a hipótese de existir ação de genes 
principais em dois locos independentes (Fehr et al., 1992). A distribuição contínua indicou que os genes principais e o efeito ambiental são importantes na expressão do conteúdo de ácido linolênico, levando-o a ser tratado como um caráter quantitativo.

Características organolépticas como sabor e textura do grão têm sido indicadas como sendo função do cultivar de soja. No Brasil, poucos estudos têm sido realizados com o objetivo de se comparar características organolépticas dos diferentes cultivares de soja. Reis (1957) observou que o leite de soja do cultivar Mogiana tinha melhor paladar que o do cultivar Abura. Della Modesta \& Garrutti (1982), com o objetivo de comparar a textura e o sabor de vários cultivares de soja procedentes de alguns estados brasileiros, realizaram uma série de testes de avaliação sensorial e concluíram que de um modo geral, os cultivares Paraná e Santa Rosa destacavam-se pelos melhores resultados sensoriais, independente do estado de origem.

$\mathrm{Na}$ verdade, o número de cultivares de soja existentes no mundo é de centenas; dentre eles, existem os que por possuírem sabor e odor mais brandos, são cultivados com vistas a alimentação humana de consumo direto. Assim, o melhoramento genético objetivando a utilização da soja como alimento de consumo direto é bastante viável.

A formação do aroma em soja tem sido bem investigada, está estabelecido que os $\mathrm{C}_{6}$ alquil-alquenil-aldeídos são os principais constituintes do odor desagradável, formados pela oxidação e decomposição química das moléculas de ácidos graxos insaturados (Rackis et al., 1972).

A soja é rica em lipoxigenases que consistem de três isoenzimas (1, 2 e 3), que apresentam atividades sob diferentes condições e diferentes estados do substratos para produção de hidroperoxidases; a subsequente clivagem por hidroperoxidaseliase, fornece os aldeídos $\mathrm{C}_{6}$ (Axelrod et al., 1981).

Segundo Hatanaka (1993) os precursores na semente de soja para produção de substâncias de odor desagradável por oxidação enzimática e clivagem são ácidos graxos polinsaturados, particularmente o $\mathrm{C}_{18: 2}$ linoleato que produz o hexanal e o $\mathrm{C}_{18: 3}$ linolenato que produz o (E)-2-hexanal e (Z)-3-hexenol via (Z)-3-hexenal. Estes ácidos 
graxos estão presentes nos triglicerídeos, como os ésteres de fosfolipídeos e os ácidos livres; por esta razão é difícil a inibição da formação do odor desagradável pela exclusão dos precursores de odor das sementes de soja.

Hildebrand \& Hymowitz (1981) indicaram que o desenvolvimento de cultivares de soja com deficiência em várias isoenzimas lipoxigenase mostraram uma produção limitada de aldeídos e álcoois. Pfeiffer et al. (1992) produziram novas isolinhas com deficiência em lipoxigenase 1, 2 e/ou 3. No Japão uma linhagem deficiente nas lipoxigenases 2 e 3 foi registrada como um novo cultivar de soja denominado Yumeyutaka, mostrando um leve odor desagradável e um sabor melhor do que o parental Suzuyutaka, um cultivar elite no Japão (Kitamura, 1993).

A textura é um atributo de importância primánia na avaliação sensorial dos alimentos. A textura em soja pode ser expressa pela dureza e definida pela força requerida para quebrar a semente sob pressão. Szczesniak \& Kahn (1971) verificaram que quando consumidores detectam no alimento uma textura que lhes pareça imprópria, a tendência é rejeitar o produto. Desta forma, o cozimento das leguminosas se faz necessário não só para melhorar suas características nutricionais e de sabor, bem como também para amaciar a casca e o cotilédone do grão, tornando sua textura aceitável.

Smith et al. (1960) verificaram que o tofu elaborado de diferentes cultivares de soja americanos e japoneses mostraram diferenças perceptíveis na cor e na textura. No entanto, os cultivares Lee e Jackson resultaram num tofu igual ao dos cultivares japoneses. $\mathrm{O}$ rendimento do tofu também variou com o cultivar, enquanto os conteúdos de proteína e óleo na semente afetaram o rendimento e os conteúdos de proteína e óleo do tofu.

Della Modesta \& Garrutti (1982) através de uma série de testes de avaliação sensorial executados com o objetivo de conhecer a textura de cultivares de soja provenientes de vários estados brasileiros, concluíram que os melhores cultivares, em termos de textura (mais macia), de um modo geral, eram Viçoja, Santa Rosa, Bossier, Paraná e IAC-4. 
Um outro grupo de compostos químicos associados a problemas fisiológicos no organismo humano, são os fatores anti-nutricionais (Orf, 1989). Sendo que dentre os fatores antinutricionais, os inibidores de protease (o principal é a anti-tripsina Kunitz), e os oligissacarídeos (açucares) deveriam receber maior atenção dos melhoristas. Segundo Carrão-Panizzi (1987), os inibidores de proteases interferindo na ação da tripsina sobre a digestão das proteínas, geram como sintoma um aumento no tamanho do pâncreas (hipertrofia pancreática); já os açúcares são os principais responsáveis pela formação de gases durante a digestão. A presença dos inibidores de protease encarece a soja para uso alimentar, pois se torna necessário o aquecimento para inativá-la.

$\mathrm{O}$ alto teor de proteína e minerais e a baixa atividade do inibidor de tripsina são qualidades desejáveis para a soja tipo hortaliça, que apresenta melhor sabor, aroma, textura, cozimento e baixa atividade dos inibidores de tripsina do que o tipo grão (Mohamed et al., 1991).

\subsection{Soja e saúde}

A soja é a única oleaginosa que é uma boa fonte de óleo de alta qualidade (20\%) e proteína (40\%). Numerosos estudos clínicos e epidemiológicos realizados nos últimos 35 anos demonstram a importância nutricional da soja na saúde e prevenção de doenças (Yee, Internet-a, Internet-b) .

Com baixa taxa de óleos saturados, o óleo de soja é uma excelente fonte de ácidos graxos essenciais, linolêico (50\%) e linolênico (7\%) além de olêico (24\%) e tocoferol (vitamina E). É usado como óleo vegetal de alta qualidade como função de baixar o colesterol. Um consumo moderado aliado a uma dieta com níveis adequados de gordura pode trazer ótimos benefícios (Yee, Internet-a)

A proteína de soja consumida em alimentos tradicionais ou como ingrediente em alimentos formulados, contribui significativamente para a melhoria da qualidade nutricional de grande parte da população mundial. Muitos estudos recentes mostram efeitos de diminuir a hipercolesterolemia e possíveis efeitos anticarcinogênicos na soja e seus derivados. A fibra de soja mostrou melhora na tolerância à glicose e na resposta à 
insulina em pacientes diabéticos. A soja também pode ter um impacto positivo na osteoporose, doenças renais e diarréia pediátrica provendo nutrientes de alta qualidade com baixo custo para as populações necessitadas dos países em desenvolvimento (Yee, Internet-a).

Há uma vasta literatura indicando que proteína de soja reduz a concentração de colesterol no sangue em experimentos com animais e em humanos. Carroll (1991) comenta que mais de 25 estudos clínicos mostraram que quando a proteína de soja substitui a proteína animal ou é adicionada à dieta reduz os níveis de colesterol em pessoas hipercolesterolênicas. Redução em $20 \%$ ou mais nos níveis de colesterol total e baixa densidade (LDL) foi obtida com dietas ricas em proteína. Níveis de triglicerídeos também diminuem, especialmente em sujeitos com hipergliceridermia, mas dietas com proteína de soja aparentemente têm um pequeno efeito nos níveis de colesterol de alta densidade. Geralmente, pessoas com hipercolesterolemia apresentam melhor resposta que pessoas colesterolêmicas normais (Sirtori et al., 1979; Grundy et al., 1983; Van Raaij et al., 1982). Um estudo recente de Potter et al., citado por Yee (Internet-a), indica que 25 gramas de proteína de soja com ou sem fibra efetivamente diminui os níveis de colesterol em indivíduos com níveis de colesterol em torno de $5,7 \mathrm{mmol} / \mathrm{L}$ ou maior. $\mathrm{O}$ decréscimo é atribuído principalmente à alteração nos níveis do colesterol de baixa densidade; quanto maiores os níveis de colesterol iniciais, maiores são os decréscimos (Bakhit et al., 1994).

O mecanismo e os componentes da soja responsáveis pela diminuição dos efeitos do colesterol não estão muito bem definidos. Alguns pesquisadores sugerem uma diminuição na taxa de absorção do colesterol e/ou reabsorção da bile como responsáveis, enquanto outras propostas indicam mudanças na condição endócrina como uma alteração na proporção insulina/glucagon e na concentração de hormônios da tiróide como responsáveis (Sanchez et al., 1985). Karazawa et al. (1993) sugerem que a soja inibe a oxidação do colesterol de baixa densidade em adição à diminuição do colesterol de alta densidade. Interações entre proteínas e outros componentes da dieta como fibras, ácido fítico, minerais, saponinas e isoflavonas também podem contribuir para os efeitos hipolipidêmicos. 
A composição das gorduras e óleos da dieta também podem afetar a incidência de doenças coronarianas pela sua influência no metabolismo lipídico e lipoprotéico. O óleo de soja possui um bom balanço de ácidos graxos, rico em dois ácidos graxos essenciais, $55 \%$ de ácido linolêico e $7 \%$ de ácido linolênico, e com $24 \%$ de ácido olêico. Muitos esforços tem sido feito na pesquisa no sentido de se estimar os efeitos dos ácidos graxos saturados, poliinsaturados e monoinsaturados presentes na composição do colesterol. É bem conhecido que dietas ricas em gorduras saturadas tendem a aumentar o colesterol e aumentam o risco de doenças cardíacas. Estudos de Pakpaenkitvatana et al. (1989), mostraram que uma dieta adequada de óleo de soja provê $10,6 \%$ do total de energia com o ácido linolênico, podendo aumentar os níveis de ácido linoléico em homens saudáveis com uma diminuição concomitante do colesterol total e de baixa densidade mantendo ou não o fluxo de colesterol. O ácido linolênico é um precursor do ácido graxo Ômega-3 e mostra de um modo crescente que possui funções hipolipodêmicas. Ele também é precursor de prostaglandinas, um poderoso hormônio que é um importante componente das biomembranas.

A lecitina de soja, um derivado do óleo de soja é efetivo na redução da agregação das plaquetas do sangue, prevenindo a trombose ou entupimento de vasos. Jannace et al. (1992) mostraram que a lecitina apresenta efeitos favoráveis em inúmeras funções do sistema imunológico e que a qualidade da gordura pode fazer o papel de ajustar as funções do sistema imune.

Uma crescente atenção vem sendo demonstrada com o potencial da soja na prevenção do câncer. Diversos componentes com atividade anticarcinogênica foram identificados em concentrações relativamente altas em soja. A soja é uma rica fonte do inibidor de protease Bowman-Birk, e a única fonte de saponinas, uma isoflavona (Yee, Internet-a).

Bames et al. (1990) mostraram que dietas compostas por no mínimo 5\% de soja inibem significativamente em até $40 \%$ o câncer de mama induzido quimicamente em ratas. $\mathrm{O}$ efeito similar a hormônios das isoflavonas da soja também foi demonstrado em humanos. Um estudo recente realizado por Cassidy et al. (1994) mostrou que mulheres 
em pré-menopausa alimentadas com produtos à base de soja têm um aumento no comprimento do ciclo mestrual em aproximadamente 2,5 dias. Estudos conduzidos por Lee et al. (1991) mostraram um decréscimo de 50\% no risco de câncer associado com o consumo regular de alimentos à base de soja em mulheres pré-menopausa. $\mathrm{O}$ efeito antiestrogênico das isoflavonas da soja é atribuída a genisteína e a daidzina, ambos são compostos bifenólicos que têm semelhanças estruturais com hormônios esteróides e com a ativação de tecidos com receptores de estrógeno. As isoflavonas também inibem enzimas como as proteínas tirosina quinases envoltas no crescimento de câncer (Sharma et al., 1982; Adlercruetz, 1990; Mousavi \& Adlercruetz, 1993).

Mais de 30 trabalhos indicam que quando a genisteína adere a células cancerosas in vitro, o crescimento é inibido. A genisteína também mostrou inibição da angiogênese in vitro. A angiogênese ou desenvolvimento de vasos sangüíneos, é necessária para o crescimento de tumores quando estes têm um tamanho muito pequeno. Numerosos estudos conduzidos no Japão e na China confirmam o efeito protetor da soja, mostrando que quem consome tofu e leite de soja apresentam menor risco de câncer do que quem raramente consome estes alimentos. Um trabalho condurido por Dwyer et al. (1994) sugere que alimentos tradicionais à base de soja não-fermentada como tofu e leite de soja, que contêm altos níveis de genisteína e daidzeína, e alimentos à base de soja usadas como dietas suplementares sejam testadas para averiguar os níveis de isoflavonas, como a genisteína e a daidzina. Kennedy et al. (1993) também reportaram que estratos de soja contendo o inibidor de protease Bowman-Birk inibem experimentalmente câncer de colo, pulmão e boca.

É geralmente aceito que fibras solúveis estão associadas com baixo colesterol e a melhora no controle da diabete, enquanto fibras insolúveis estão associadas com a melhora das funções intestinais (Schneeman, 1986). A fibra de soja porém aparece como tendo estes efeitos fisiológicos. Estudos conduzidos por Tsai et al. (1983) indicaram que o peso úmido e o conteúdo de umidade das fezes aumenta significativamente quando fibra de soja é consumida (25 gramas). Lo et al. (1983), conduzindo testes de tolerância à glicose em pacientes com hiperlipidermia, verificaram que a adição de fibra de soja ( 25 
gramas) na dieta reduziu significativamente a abstinência de glicose em $8,5 \%$ e também reduziu significativamente o tempo de resposta à oposição a glicose oral em $20 \%$ em pacientes com hipercolesterolemia tipo II-A.

Deficiência de cálcio, ausência de atividade física, pré disposição genética e consumo excessivo de proteínas são fatores considerados como as maiores influências na ocorrência de osteoporose. Omi et al. (1994) relataram que o leite de soja é uma excelente fonte para aumentar a densidade mineral dos ossos e a resistência mecânica dos ossos. A presença de peptídeos da soja se mostra um efetivo componente na aceleração da absorção de cálcio pelo intestino. Recentes estudos também indicam que a absorção de cálcio de muitas plantas é comparável ao cálcio diário exceto em plantas que contêm altos níveis de oxalato e/ou fitato (Heaney et al., 1991). O fitato diminui a disponibilidade de cálcio, mas não tanto quanto o oxalato. De qualquer modo, conteúdo de oxalato de $5,3 \mathrm{mg} / \mathrm{g}$ e níveis relativamente altos de fitato na soja podem causar uma absorção de cálcio apenas um pouco menor do que o leite (Heaney et al., 1991). A absorção de cálcio de tofu coagulado com sulfato de cálcio é comparável ao queijo, carbonato de cálcio e leite desnatado. Recentemente, pesquisas sugerem que as isoflavonas da soja tem um efeito direto na saúde dos ossos, possivelmente inibindo a reabsorção dos ossos.

A deficiência de ferro é uma das mais comuns deficiências nutricionais no mundo. A soja é rica em ferro mais também contêm fitatos com ligações bivalentes. Isto explica o possível efeito inibidor da soja na absorção de ferro. Pesquisas como as de Lynch et al. (1985) mostram que enquanto a soja reduz a absorção de ferro não-heme, em came há um aumento da absorção de ferro-heme. Macfarlane et al. (1990), em estudo sobre alimentos à base de soja asiáticos, verificou que alimentos fermentados como molho de soja, tempeh, natto e miso promovem uma absorção maior quando comparada com a farinha de soja, indicando que $o$ processamento atua modificando significativamente o complexo protéico da soja. 


\subsection{Qualidade da soja tipo alimento}

Segundo Vello (1992b), a soja usada diretamente como alimento deve apresentar maior teor e melhor qualidade de proteínas; maiores teores de aminoácidos sulfurados (metionina, cistina); menor teor de óleo e melhor qualidade de óleo, com menores teores de ácidos graxos insaturados linolêico e linolênico e de lipoxigenases; sabor adocicado lembrando o de nozes; cor clara das sementes (cotilédones, tegumento e hilo com cores semelhantes, de preferência creme) e tamanho grande $(\geq 20 \mathrm{~g} / 100$ sementes).

De acordo com Bernard (1999), no programa de melhoramento de cultivares adaptados para uso nos Estados Unidos e para exportação para o Japão, o tamanho das sementes e a aparência são os principais objetivos a serem alcançados. $O$ tamanho de sementes para natto ou broto de soja deve variar entre 7 e $10 \mathrm{~g} / 100$ sementes. Sementes para tofu devem ter $20 \mathrm{~g} / 100$ sementes ou mais e para edamame deve ter pelo menos 25 $\mathrm{g} / 100$ sementes. As sementes devem ter boa aparência e serem livres de pigmentos marrons ou pretos. Cor amarela na semente e no hilo são preferidos, mas para edamame algum esverdeamento na casca e um marrom claro no hilo são aceitáveis.

Carrão-Panizzi (1987) enfoca que a soja tipo hortaliça ou edamame tem sabor superior (mais leve), com sementes maiores e cozimento mais rápido que a soja tipo grão de cozimento lento e de sabor amargo, adstringente.

A soja tipo hortaliça deve apresentar baixo nível de inibidores da tripsina, poucos oligossacarídeos não digeríveis e mais vitaminas do que a soja tipo grão (Rackis, 1972). As sementes grandes do edamame são consideradas superiores em sabor textura e facilidade de cozimento, mas diferenças significativas na composição química não foram identificadas (Rackis, 1981). Níveis de ácido fítico são altos e podem explicar porque o edamame é mais tenro e fácil de cozinhar. $O$ edamame é delicadamente doce, com sabor suave e textura de nozes, com menor sabor de feijão cru. Por serem grandes, apresentam vagens facilmente estragáveis, sementes com uma frágil casca e ramos que podem apresentar diversos nós sem vagens (Smith \& Van Duyne, 1951; Shanmungasudaram et al., 1989; Bernard, 1999). 
Os níveis de proteína na soja tipo hortaliça são ligeiramente superiores do que na soja tipo grão, mas pesquisas recentes indicaram que sementes grandes apresentam uma alta porcentagem de óleo e menos proteína do que sementes pequenas (Smith \& Circle, 1972; Reddy et al., 1989). Contrariamente, Gupta et al. (1976) observaram que sojas de sementes grandes são nutricionalmente superiores em proteína. Uma vez que proteína e teor total de açúcar estão negativamente associados, muita proteína leva a uma deficiência de açúcar, um importante componente do sabor. Inversamente, o conteúdo de óleo e açúcares totais estão positivamente associados, mas um excessivo sabor de óleo é inaceitável (Hymowitz et al., 1972).

A qualidade da soja tipo hortaliça é avaliada pela aparência, aroma, sabor e textura firme após cozimento. Morfologicamente, as vagens devem apresentar pubescência branca, preferencialmente lisas; o hilo deve ser marrom claro ou cinza; as vagens devem apresentar duas ou três sementes e não devem estar danificadas; a maior parte das vagens deve apresentar no mínimo $5 \mathrm{~cm}$ de comprimento; 500 gramas devem conter menos de 150 vagens; o peso de 100 sementes deve exceder 30 gramas (Shanmungasundaram et al., 1989); as vagens devem ser completamente verdes, sem pontas amarelecidas [Ida, citado por Konovsky et al.(1994)]; a casca da semente madura pode ser amarela ou verde para marrom ou preta (Kiuchi et al., 1987; Shanmungasundaram et al., 1989).

A soja tipo hortaliça é comercializada de três formas diferentes: fresca, congelada ou enlatada, sendo que a forma fresca é a mais popular. No Japão a soja tipo hortaliça fresca é comercializada na forma de feixes de ramos desfolhados contendo as vagens ou na forma de vagens soltas (Liu, 1996). Ida, 1990, citado por Konovsky et al. (1994), relata que a Província de Iwate, no Japão, classifica como edamame tipo A aquelas que contêm $90 \%$ ou mais de vagens com 2 ou 3 sementes. As vagens devem estar perfeitamente desenvolvidas, completamente verdes e não mostrar sinais de injúrias ou manchas. Edamame do tipo B devem conter $90 \%$ ou mais de vagens com 2 ou 3 sementes, mas podem estar ligeiramente verdes e algumas vagens podem estar levemente manchadas, injuriadas, mal formadas, curtas ou apresentar sementes pequenas. Em ambos 
os tipos, as vagens não devem se apresentar muito maduras, doentes, danificadas por insetos, vagens com uma única semente, mal formadas, amarelecidas, manchadas ou maduras. As sojas do tipo hortaliça são colhidas e utilizadas verdes, quando as plantas estão com sementes e vagens imaturas, entre os estádios de crescimento $R_{6}$ e $R_{7}$ (Shanmungasundaram et al., 1989).

A soja tipo hortaliça é consumida, principalmente, como tira-gosto e, também como legume, em adição a sopas ou processados em doces. Como tira gosto, as vagens são ligeiramente cozidas no vapor. Como legume, os grãos, maduros ou imaturos, cozidos são misturados em saladas, refogados ou combinados com outras hortaliças (Konovsky \& Lumpkim, 1990).

O tofu ou coalho de soja possui cerca de $89,0 \%$ de umidade, $5,5 \%$ proteína e $3,8 \%$ de óleo. O rendimento e a textura variam de acordo com a soja utilizada. A qualidade do tofu é afetada pelo cultivar utilizado, mais especificamente pelo conteúdo de proteína e óleo. Foi encontrada uma alta correlação do tofu com a composição química do leite de soja, o qual depende da matéria prima utilizada. Nos casos em que o leite de soja contêm um grande quantidade de proteína e de óleo, um alto rendimento de tofu é obtido. Em relação a isto, as taxas de proteína e óleo no leite de soja também são importantes. O sabor do tofu está estreitamente ligado com o conteúdo de açúcar livre na soja porque estes contêm um elevado teor no soro. $\mathrm{O}$ conteúdo de sacarose ou de outro açúcar essencial na soja, varia substancialmente entre os cultivares. Cultivares com elevados teores de proteína geralmente apresentam um baixo conteúdo de sacarose (Taira et al., 1990). Wang et al. (1983) observaram que diferenças nos cultivares de soja afetaram a composição e a cor do tofu. Lin et al. (1990) relataram que o rendimento do tofu não foi afetado pelo tamanho do grão. Bernard (1999) menciona que para produção de tofu é desejável, que os cultivares apresentem alto teor de proteína e de açúcares, capacidade de espumejar, hidrofobicidade, cor amarela e hilo claro.

A qualidade desejável da soja para produção de miso ou pasta de soja fermentada é uma cor de hilo claro, uma alta capacidade de absorver água, uma estrutura leve e uma cor clara ou amarelo-claro em grãos cozidos. A alta capacidade de absorção 
de água está correlacionada com um alto conteúdo de carboidratos favorecido por um cozimento brando dos grãos. Não foram observadas correlações entre o conteúdo de proteína e de óleo e a capacidade de absorção de água. O conteúdo de sacarose em 105 amostras japonesas, incluindo 60 cultivares e sete linhagens melhoradas, variaram quanto a taxa de matéria seca de $3,67 \%$ a 9,64\% (Taira et al., 1990).

Para o processamento do natto, ou soja fermentada, são selecionados os grãos de soja inteiros com superficie brilhante. Para obter grãos levemente embebidos é requerida uma alta capacidade de absorção de água; diferentemente, grãos pesadamente embebidos favorecem o aparecimento de um aroma indesejável de amoníaco no natto. A composição dos açúcares livres nos grãos também influencia a efetividade da fermentação; sendo que a sacarose é consumida mais rapidamente do que a rafinose e a estaquiose no processo de fermentação. Sob uma elevado conteúdo de sacarose, a temperatura se eleva nos primeiros estágios do processo de fermentação. Esta condição de temperatura não é apropriada na fabricação do natto. A estaquiose é consumida após a sacarose; assim o processo de fermentação prossegue gradualmente. Isto fornece condições apropriadas para o processamento. Um alto conteúdo de estaquiose é geralmente observado em grãos de tamanho pequeno (Taira et al., 1990). Bernard (1999) menciona que para natto é desejável uma semente com alta capacidade de absorver água, alto teor de proteína e açúcar, baixo teor de cálcio, sementes pequenas e esféricas, com casca livre de defeitos. Sementes de tamanho pequeno são obtidas de um tipo de soja de crescimento indeterminado importado da China e dos Estados Unidos (Taira et al., 1990).

\subsection{Herança de caracteres}

\subsubsection{Caracteres da planta}

O ciclo da planta pode ser dividido em dois períodos: vegetativo e reprodutivo. Por sua vez o período vegetativo pode ser subdividido nos períodos juvenil e indutivo. $O$ período juvenil compreende o período da emergência da plântula até o estádio de desenvolvimento em que a planta não responde às condições fotoperiódicas 
favoráveis à indução do florescimento; este período que antecede o período indutivo, termina com o aparecimento da primeira flor (Destro, 1991).

Segundo Shanmungasudaram \& Tsou (1978) o período juvenil tem uma duração mínima de nove dias; quanto maior o período juvenil maior será a tolerância ao fotoperíodo.

Cultivares exóticos provenientes do Japão, China e Coréia apresentam uma grande sensibilidade à variação do fotoperíodo, sendo que uma solução viável para contornar esse problema é a introdução de genes para período juvenil longo (Hinson, 1989; Kiihl \& Garcia, 1989); uma segunda solução envolve a identificação de linhagens insensíveis ao fotoperíodo como parentais em programas de melhoramento (Criwell \& Hume, 1972); e uma terceira envolve o uso de cultivares com hábito de crescimento determinado (Hiromoto, 1990)

Toledo \& Kiihl (1982a), estudando o cruzamento do cultivar Santa Maria com a linhagem D 72-7842, concluíram que há pelo menos três genes que controlam o período juvenil. Toledo \& Kiihl (1982b), estudando vários cruzamentos, encontraram apenas um gene controlando esse caráter.

Segundo Kiihl, em comunicação pessoal a Destro (1991), o controle genético do período juvenil longo em alguns cultivares nacionais é o seguinte:

- cultivar Paranagoiana: um gene recessivo;

- cultivar SS1: um gene recessivo;

- cultivar BR 23: dois genes recessivos;

- cultivar Tropical: $\quad \mathrm{n}$ genes recessivos;

- cultivar Doko: $\quad \mathrm{n}$ genes recessivos (nem todos os genes de Tropical);

- BR 83-147 desconhecido.

A herança da maturidade é considerada como sendo um caráter quantitativo. Contudo, existem trabalhos indicando a existência de um controle por genes principais (Singh \& Anderson, 1949).

Bernard (1971) propôs que dois pares de genes independentes afetam a floração e a maturação da soja. Os genes dominantes $E_{1}$ e $E_{2}$, apresentaram dominância 
parcial em relação ao florescimento e maturação tardia, sendo $E_{1}$ ligado à cor de pubescência cinza. Buzzell (1971) relatou um outro gene, denominado $E_{3}$, cujo alelo dominante determina sensibilidade à luz fluorescente, atrasando a floração e a maturação. Buzzell \& Voldeng (1980), estudando a insensibilidade da soja a fotoperíodos longos, conseguiram evidências da existência de um só gene controlando a insensibilidade e a denominaram de $E_{4}$. McBlain \& Bernard (1987) encontraram um novo gene afetando dias para florescimento e maturação em soja e denominaram-no de $E_{5}$. Bonato \& Vello (1999a, 1999b) identificaram o gene $E_{6}$ que determina florescimento e maturação precoces no cultivar Paraná, e $e_{6}$ para os alelos que determinam florescimento e maturação tardios nos cultivares Paranagoiana e SS-1. Thseng e Hosokawa, citado por Gilioli (1979), identificaram dois genes complementares, $A$ e $B$, controlando os caracteres dias para floração e maturação. Toledo \& Kiihl (1982b), em estudos com análise dialélica, observaram a existência de um gene cujo alelo recessivo causava um aumento no ciclo da planta.

Bonato (1989) propôs os seguintes genótipos para o controle da maturidade sob condições de dias curtos de parentais envolvidos em cruzamentos dialélicos:

- cultivar Paraná: $\quad E_{1} / E_{1} E_{2} / E_{2}$;

- cultivar Paranagoiana: $\quad e_{1}^{\mathrm{a}} / e_{1}^{\mathrm{a}} E_{2} / E_{2}$;

- cultivar SS1: $\quad e_{1}^{\mathrm{b}} / e_{1}^{\mathrm{b}} E_{2} / E_{2}$;

- cultivar Pirapó: $\quad E_{1} / E_{1} e_{2} / e_{2}$;

sendo que os genótipos $e_{1} \mathrm{a} / e_{1}{ }^{\mathrm{a}} E_{2} / E_{2}$ causaram um aumento médio do ciclo de 39 dias; $e_{1}^{\mathrm{b}} / e_{1}^{\mathrm{b}} E_{2} / E_{2}$ de 23 dias; $E_{1} / E_{1} e_{2} / e_{2}$ de 9 dias; $e_{1}{ }^{\mathrm{a}} / e_{1}{ }^{\mathrm{a}} e_{2} / e_{2}$ de 68 dias e $e_{1}{ }^{\mathrm{b}} / e_{1}^{\mathrm{b}} e_{2} / e_{2}$ de 38 dias.

A análise do caráter hábito de crescimento foi estudado primeiramente por Woodworth, citado por Hiromoto (1990), que concluiu que este era controlado por um par de alelos, sendo que o alelo para o hábito determinado $\left(D t_{1}\right)$ tem dominância completa sobre o hábito de crescimento indeterminado $\left(d t_{1}\right)$. Bernard (1972) relatou um terceiro tipo de hábito de crescimento, o semi-determinado ( $\left.D t_{2}\right)$, verificando que $d t_{1}$ é parcialmente recessivo para $D t_{1}$ e epistático sobre $D t_{2}$ e $d t_{2}$. Portanto, como são dois 
pares de alelos a controlar a manifestação do hábito de crescimento, o fenótipo correspondente a cada genótipo se forma pela combinação dos quatro alelos dois a dois.

Os controles gênicos do período reprodutivo e da altura da planta no florescimento diferem ao apresentado na maturidade, existindo um grande efeito ambiental; em ambientes sombreados há uma tendência das plantas crescerem mais em altura com um número menor de ramificações; já em ambientes ensolarados, há menor crescimento em altura e maior número de ramificações (Camacho, 1971). Resultados semelhantes foram obtidos por Muszynski \& Jaranowski (1983) e Konieczny et al. (1994), os quais verificaram que a altura da planta, o número de ramificações e a altura da primeira vagem dependem do genótipo e podem ser modificadas pela densidade de semeadura.

Shanmungasundaram \& Tsou (1978) verificaram que o número de nós, a altura da planta no florescimento, o número de dias para a maturidade e o número de vagens por planta são influenciados pelo fotoperíodo nas linhagens sensíveis. $\mathrm{O}$ aumento inicial na altura e no maior número de nós são essenciais para aumentar o número de vagens nas linhagens insensíveis. Um prolongamento da fase de maturação contribuiria para aumentar a produtividade, devido à maior disponibilidade de nutrientes. Cultivares com crescimento indeterminado apresentam o risco de translocar nutrientes para o ápice do caule, diminuindo a disponibilidade de substrato para o enchimento de grãos.

Foram obtidos valores de herdabilidade no sentido amplo variando entre os caracteres: número de dias para a maturidade, $42,0 \%$ a 99,0\% (Chauhan \& Singh, 1984; Freire Filho, 1988; Bonato, 1989; Destro, 1991; Hamawaki, 1998); altura da planta na maturidade, 22,0\% a 92,0\% (Chauhan \& Singh, 1984; Freire Filho, 1988; Destro, 1991); produtividade de grãos, 22,0\% a 95,0\% (Chauhan \& Singh, 1984; Freire Filho, 1988; Bonato, 1989; Destro, 1991; Pacova, 1992; Hamawaki, 1998); valor agronômico, 34,0\% a 80,0\% (Freire Filho, 1988; Destro, 1991; Pacova, 1992).

Para a herdabilidade no sentido restrito também foram encontradas grandes variações entre os caracteres: Altura de planta na maturidade, $0,0 \%$ a $94,0 \%$ (Singh et al., 1974; Weaver \& Wilcox, 1982; Cecon et al., 1984a; Cecon et al., 1984b; Pereira et 
al., 1984; Freire Filho, 1988; Bonato, 1989); produtividade de grãos, 13,0\% a 58,0\% (Singh et al., 1974; Weaver \& Wilcox, 1982; Pereira et al., 1984; Freire Filho, 1988; Bonato, 1989); valor agronômico, 17,0\% a 29,0\% (Freire Filho, 1988; Pacova, 1992).

\subsubsection{Caracteres de vagem e de semente}

A soja tem uma grande variedade de cores e de formas na semente. As cores mais comuns de sementes são o amarelo, o verde, várias tonalidades de marrom e o preto. Diferentes distribuições de pigmentos pretos ou marrons podem ocorrer nos tegumentos pretos ou verdes. As diferenças encontradas entre a maioria dos cultivares nas cores preta e marrom se devem a dois locos $T$ e $R$ com a ação dos locos $V$ e $W_{1}$ (Tabela 3) (Destro et al., 1990).

Tabela 3. Cor do tegumento da semente.

\begin{tabular}{ll}
\hline Fenótipo & Genótipo \\
\hline Preto (Pubescência marrom) & $T_{-} R_{-}$ \\
Marrom (Pubescência marrom) & $T_{-} r r V_{-}$ \\
Marrom-avermelhado (Pubescência marrom) & $T_{-} r r v$ \\
Preto-imperfeito (Pubescência cinza e flor púrpura) & $T_{-} R_{-} W_{1_{-}}$ \\
Marrom-claro (Pubescência cinza e flor púrpura) & $T_{-} R_{-} w_{1} w_{1}$ \\
Marrom escuro (Pubescência cinza) & $T_{-} r r$ \\
\hline
\end{tabular}

FONTE: Destro et al. (1990).

Muitos cultivares de soja apresentam uma fina carnada, a qual dá a semente um brilho fraco, enquanto outros cultivares não apresentam essa camada ou apenas pouca quantidade deste material, exibindo desta maneira, o tegumento da semente brilhante. Três genes complementares, $B_{1}, B_{2}$ e $B_{3}$, foram necessários para apresentar o tegumento da semente fosco, no cultivar Sooty (Woodworth, citado por Destro et al., 1990). 
Quanto a cor, o hilo pode ser cinza, amarelo, preto, preto imperfeito, amarelo-alaranjado, marrom ou marrom-avermelhado. A cor da pubescência pode ser marrom ou cinza. A flor pode ser roxa ou branca (Destro et al., 1990).

Quatro locos adicionais afetam a distribuição dos pigmentos pretos e marrons nas sementes. Restrição do pigmento ao padrão sela (similar ao $i^{\mathrm{k}}$ ) foi encontrada no cultivar Kurakake, em virtude de um único gene recessivo, $k_{1}$. $O$ gene recessivo $k_{2}$, não alélico, nem ligado ao $k_{1}$, causa também o padrão sela na semente, que é sempre marrom, independente dos efeitos do genes que controlam a cor do hilo (Tabela 4) (Destro et al., 1990).

Tabela 4 Distribuição dos pigmentos na semente.

\begin{tabular}{llc}
\hline Fenótipo & & Genótipo \\
\hline Hilo claro - & $\begin{array}{l}\text { Pigmento escuro, reduzido em intensidade a um hilo cinza } \\
\text { (com tegumentos pretos) ou completamente ausentes (com }\end{array}$ & $I$ \\
& $\begin{array}{l}\text { tegumentos marrons ou marrom-claros). } \\
\text { Hilo escuro - }\end{array}$ & Pigmento escuro presente apenas no hilo. \\
Sela - & Pigmento escuro presente na forma de sela, estendendo-se & $i^{\mathrm{i}}$ \\
& até a metade do tegumento, aproximadamente. & \\
Cor igual - & Pigmento escuro no tegumento inteiro. & $i$
\end{tabular}

FONTE: Destro et al. (1990)

Existe uma considerável variação entre os cultivares de soja na quantidade, tamanho, orientação, distribuição e cor da pubescência que, freqüentemente, estão presentes no caule, pecíolos, folhas, cálices e vagens; vários tipos de pubescência são bastantes distintos para permitir uma análise genética (Destro et al., 1990).

A pubescência dos cultivares de soja é marrom quando ocorre a presença de um pigmento marrom na maioria dos pêlos, ou cinza, em razão da ausência do pigmento marrom. A cor da pubescência é controlada por um único par de genes, sendo a cor marrom $(T)$ dominante sobre a cor cinza ( $t$ ) (Woodworth, citado por Destro et al., 1990). 
O par de genes $T d t d$ controla a intensidade do pigmento em plantas que possuem o alelo $T$ (Bernard, 1975).

A cor da vagem é verde até o estádio $R_{7}$ (escala de Fehr \& Caviness, 1977) e, depois deste estádio, a vagem começa a apresentar a coloração do cultivar, que pode ser preta, marrom ou cinza. Dois pares de genes controlam a cor da vagem: $L_{1}$, condiciona o aparecimento da vagem de cor preta; $l_{1}$ com $L_{2}$, marrom; e $l_{1}$ com $l_{2}$, cinza (Bernard, 1967).

O tamanho da semente, expresso pelo peso de 100 sementes (PCS), encontra-se sobre controle genético (Hartwig, 1973), mas, também é afetado pelas condições ambientais ocorridas durante o desenvolvimento da semente, como observado por Nakagawa et al. (1986).

Hartwig (1973) relata uma grande variação no tamanho da soja, podendo-se observar sementes desde 4 até $55 \mathrm{~g} / 100$ sementes. Segundo Liu (1996), o tamanho das sementes de soja varia muito entre os cultivares, ficando entre 7,6 e 30,3 g/100 sementes, e, que a maior parte da soja para produção de óleo e farelo tem sementes entre 15 e 23 $\mathrm{g} / 100$ sementes, em geral, as plantas que crescem sob condições de estresse ambiental (deficiências nutricionais, hídricas ou incidência de pragas e doenças) tendem a produzir sementes menores que aquelas crescidas sob condições normais.

Miranda et al. (1984), realizando cruzamentos recíprocos entre os cultivares Paraná x IAC 73-228 e Biloxi x IAC-7, verificaram, em dois dos quatro cruzamentos, que houve pronunciado efeito materno para tamanho das sementes.

O tamanho da semente é quantificado pelo peso de 100 sementes (PCS). Para o consumo humano direto, cultivares com tamanho grande (>20 g / 100 sementes) são os preferidos. $\mathrm{O}$ desenvolvimento de cultivares com sementes grandes tem envolvido cruzamentos entre parentais de sementes grandes, produzindo progênies com o tamanho desejado. Segundo Bravo et al. (1981) os parentais de sementes grandes produzem menos em relação aos cultivares de sementes médias (PCS $=12$ a $19 \mathrm{~g})$.

Vello et al. (1984) verificaram que uma população obtida através do retrocruzamento $F_{1}$ (Parental adaptado $x$ Introdução de plantas ou PI) com o parental 
adaptado, apresenta uma quantidade de genes exóticos introduzidos que maximizam a variabilidade genética sem causar reduções drásticas na produtividade de grãos. Miranda et al. (1984) recomenda que o parental de sementes grandes seja utilizado como fêmea, tanto no cruzamento inicial como nos retrocnuzamentos, devido ao efeito materno sobre o tamanho da semente.

Bravo et al. (1981), em um estudo para tamanho das sementes em cruzamentos, concluiu que a média da população segregante foi predita pela média aritmética ou geométrica dos parentais, refletindo a participação de ação gênica aditiva e ou epistasia aditiva $\mathrm{x}$ aditiva no controle do tamanho das sementes.

Estimativas da herdabilidade para o caráter tamanho das sementes em soja variando de $44 \%$ a $49 \%$ foram observadas por Brim (1973) e por Burton (1987). Foram obtidas herdabilidades no sentido restrito variando de $36 \%$ a $77 \%$ por Anand \& Torrie (1963), 94,8\% por Pereira et al. (1984), 15\% por Destro et al. (1987), 18,5\% por Pacova (1992). Herdabilidades no sentido amplo variando de $41,5 \%$ a $86,5 \%$ foram obtidas por Harrison (1981), Chauhan \& Singh (1984), Pereira et al. (1984) e Destro et al. (1987).

Do peso total dos grãos de soja industrializado, 20,0\% corresponde ao óleo que, do ponto de vista qualitativo, é composto pelas seguintes proporções de ácidos graxos: $11,0 \%$ de ácido palmítico, 3,0\% de ácido esteárico, $22,0 \%$ de ácido oléico, $56,0 \%$ de ácido linoléico e 8,0\% de ácido linolênico (Wilcox, 1985). Ao ácido linolênico é atribuída a responsabilidade pela diminuição na qualidade do óleo, devido a presença de três insaturações em sua molécula e por se constituir no substrato das lipoxigenases, ao mesmo tempo que liberam compostos indesejáveis que provocam o ranço (Hammond, 1985).

Estimativas sobre o teor de óleo em cultivares de soja tipo alimento são escassas na literatura. Marega Filho (1999), trabalhando em Londrina, encontrou para progênies de soja tipo alimento variações de $12,0 \%$ a 20,4\% (média de 16,6\%). Teixeira et al. (1984), trabalhando com cultivares de soja tipo grão recomendados para o Estado de São Paulo, encontraram em média 22,2\% de óleo. Hamawaki (1998), trabalbando com progênies selecionadas em cruzamentos óctuplos de soja tipo grão, nas gerações 
$F_{4: 3[8]}$ e $F_{5: 3[8]}$, obteve teores de óleo entre $19,0 \%$ a $25,4 \%$. Segundo estes autores, os conteúdos de óleo são fortemente influenciados pelo genótipo da planta, local, condição de cultivo, e até mesmo, pela posição da vagem na planta.

\subsection{Correlações entre caracteres}

Os estudos de correlações entre caracteres têm grande importância em programas de melhoramento, principalmente quando é dificil a seleção de um caráter desejável, em virtude da baixa herdabilidade ou de problemas de medição e identificação (Goldenberg, 1968).

A seleção indireta, com base na resposta correlacionada, pode ser usada, permitindo ao melhorista progressos mais rápidos do que quando se usa a seleção direta da característica desejada. Porém, surgem dificuldades quando duas características apresentam correlação significativa e positiva e uma delas é indesejável, ou, quando as duas características são desejáveis, mas apresentam correlação significativa e negativa (Falconer, 1989).

Foi encontrada uma correlação negativa pronunciada entre os teores de óleo e de proteínas em soja (Johnson et al., 1955b; Thorne \& Fehr, 1970; Brim \& Burton, 1979; Wilcox, 1985). Smith \& Circle (1972) estimaram a correlação entre estes caracteres em $-0,60$. Johnson (1961) estimou que para cada dois pontos percentuais de acréscimo no conteúdo de proteína corresponde a uma redução de um ponto percentual em óleo.

Marschalek (1995) estimou a correlação genética entre teor de óleo (\%OL) e produção de grãos (PG) em 0,33; produção de grãos e teor de proteína em -0.47 e entre teor de óleo e teor de proteína em $-0,31$. Tais resultados indicam que a seleção baseada somente no teor de proteína tende a acarretar reduções na produção e no teor de óleo.

Smith \& Camper (1975) e Dawande \& There (1993) observaram correlações positivas entre o tamanho das sementes e o crescimento da planta de soja. Por outro lado Singh et al. (1972) e Gilioli (1979a) não observaram diferenças na produtividade e na emergência de plantas, devido ao tamanho das sementes. 
Número de dias para florescimento (NDF), período reprodutivo (PR) e peso de cem sementes (PCS) estão correlacionados positivamente com teor de óleo (\%OL) (Wilcox, 1985; Zimback, 1992). Entretanto, resultados divergentes são encontrados na literatura. Weber \& Moothy (1952) estudando rês populações de soja, constataram correlações fenotípicas e genotípicas negativas entre \%OL e NDF, NDM, APM em todas as populações; entre \%OL e produtividade de grãos (PG) em duas populações e entre $\mathrm{PR}$ e \%OL em uma população. Fontes et al. (1980) encontraram correlações negativas de \%OL com NDF, NDM e PG.

Zimback (1992) detectou correlações negativas de pequena magnitude entre $\% \mathrm{OL}$ e acamamento (AC), altura da planta no florescimento (APF), altura da planta na maturidade (APM) e valor agronômico (VA). Valores próximos de zero foram verificados entre \%OL e VA e APM. O caráter produtividade de óleo (PO) mostrou-se positivamente correlacionado com PG, VA, AC, APF, APM e NDF, porém não mostrou correlação com \%OL.

Montano-Velasco (1994) encontrou correlações negativas de pequena magnitude da \%OL com NDF, APF, NDM, AC e período reprodutivo (PR). Correlações positivas de pequena magnitude foram encontradas entre \%OL e PG. Correlações positivas de alta magnitude foram encontradas do caráter PO com APF, NDM, APM, $\mathrm{AC}$ e VA. As correlações entre os caracteres PO e PG tiveram elevada magnitude $(r=$ 0,99), indicando que PO pode ser alterado indiretamente pela seleção praticada em PG.

Farias Neto (1995) encontrou correlações negativas de pequena magnitude do caráter \%OL com APM e AC. Correlações da \%OL com NDM, VA, PG e PO foram positivas, mas quase nulas. $\mathrm{PO}$ apresentou correlações genéticas positivas e de elevado valor $\left(r_{g}>0,50\right)$ com NDM, APM, VA e PG. A correlação encontrada entre \%OL e PG foi de 0,98 , a qual associada à uma pequena correlação entre \%OL e PO, permitiu constatar que o caráter PO é fortemente dependente do caráter PG. O caráter VA apresentou estimativas de correlações altas e positivas com NDM, APM, PG e PO.

Marega Filho (1999), trabalhando com soja tipo alimento, encontrou uma pequena correlação positiva entre PCS e \%OL e uma correlação negativa de grande 
magnitude entre o teor de óleo $(\% \mathrm{OL})$ e o teor de proteína $(\% \mathrm{PR})\left(\mathrm{r}_{\mathrm{g}}=-0,65\right.$ e $\mathrm{r}_{\mathrm{f}}=$ 0,45). As correlações genotípicas encontradas apresentaram magnitudes superiores e de mesmo sentido que as fenotípicas.

Bravo et al. (1980) observaram que o uso da largura das vagens para seleção indireta para aumentar o peso de sementes de soja foi mais eficiente do que o uso do peso de sementes per se.

Segundo Frank \& Fehr (1981), o número de sementes nas vagens não tem importância prática na largura ou espessura das vagens; além disso, a seleção para comprimento ou largura das vagens em vagens cheias imaturas foi tão efetiva quanto nas maduras. A largura entre outras dimensões avaliadas, foi considerada como o caráter mais eficiente para uso na seleção indireta, além de ser a mais fácil de se obter.

Correlações fenotípicas entre a largura e o tamanho das sementes obtidas por diversos autores foram altamente significativas, $66 \%$ em vagens imaturas e $76 \%$ nas maduras para Frank \& Fehr (1981); 96\% em vagens maduras para Fraser et al. (1982); $60 \%$ em vagens maduras para Shanmungasudaram \& Chung-Ruey (1982); $80 \%$ a $90 \%$ em vagens imaturas e de $60 \%$ a $80 \%$ nas maduras para Santos (1988); $81 \%$ em vagens maduras para Pacova (1992); 90\% em vagens maduras para Yokomizo (1994); $45 \%$ em vagens maduras para Yokomizo (1999).

Yokomizo (1999) obteve correlações genotípicas positivas entre a largura da vagem e o peso de cem sementes (em torno de 65\%), concordando com as correlações obtidas por Pacova (1992) e por Yokomizo (1994).

Correlações entre o tamanho das sementes e a produtividade de grãos apresentam uma grande variação, pois foram obtidos valores de $-0,6 \%$ a $66 \%$ (Anand \& Torrie, 1963; Kwon \& Torrie, 1964; Santos et al., 1988; Yokomizo, 1999).

Leroy et al. (1991), trabalhando com cruzamentos envolvendo soja tipo broto ou natto (PCS $<10 \mathrm{~g}$ ), obtiveram correlações fenotípicas entre tamanho das sementes e outros caracteres de $-49 \%$ com número de dias para maturidade, $-35,0 \%$ para altura da planta na maturidade e de $-57 \%$ com acamamento. 
Yokomizo (1999) obteve correlações genéticas entre o tamanho das sementes e outros caracteres: $-21 \%$ com acamamento, $-66 \%$ com valor agronômico, $-65 \%$ com número de dias para a maturidade, $-43 \%$ com altura da planta na maturidade.

Segundo Kaw \& Menon (1972), o número de vagens e número de sementes por planta apresentam correlação genética positiva. Simpson \& Wilcox (1983), detectaram correlações fenotípicas altamente significativas entre produtividade e número de vagens e sementes por planta. Moro (1990) obteve correlação fenotípica positiva e significativa entre produtividade e número de vagens por planta da ordem de $0,80 \mathrm{e}$ correlação genética de 0,89 .

Kono (1986), estudando a porcentagem de vagens imaturas sem sementes, de vagens contendo uma semente e vagens contendo duas ou três sementes produzidas por dois cultivares de soja tipo edamame, plantados em diferentes épocas, observou grande variação na distribuição dos tipos de vagens. Para o cultivar Mikawashima variou de $20 \%$ a $84,5 \%$, de $12,5 \%$ a $21 \%$ e de $3,5 \%$ a $50 \%$, já para o cultivar Okubarawase a variação foi de $42,5 \%$ a $80 \%$, de $14 \%$ a $25,5 \%$ e de $6 \%$ a $32 \%$, respectivamente, para porcentagem de vagens sem sementes, vagens com uma semente e vagens com duas ou três sementes. Tais resultados indicam que o caráter número de sementes por vagem apresenta grande interação com o ambiente.

\subsection{Interação genótipos x ambientes}

Sabe-se que a manifestação fenotípica nos vegetais é o resultado da ação conjunta do genótipo com os efeitos ambientais, além de um efeito adicional de suma importância, proporcionado pela interação do genótipo com os fatores do meio ambiente em que o vegetal se desenvolve.

A avaliação da interação genótipos $\mathrm{x}$ ambientes ( $\mathrm{G} \times \mathrm{E}$ ) torna-se de grande importância no melhoramento, pois no caso de sua existência, há a possibilidade do melhor genótipo em um ambiente não apresentar o mesmo desempenho em outro, influenciando o ganho de seleção e dificultando a recomendação de cultivares com ampla adaptabilidade. Apesar de nos últimos 40 anos ter se produzido cultivares com maior 
produtividade, adaptados às práticas culturais modernas, com incorporação de resistência às pragas e doenças, aumento da qualidade das sementes, as pesquisas devem continuar de modo a visualizar um caminho para aumentar a eficiência do método e a taxa do ganho genético, de acordo com Brim (1973) incluindo:

1. O desenvolvimento de populações melhoradas, levando em consideração a origem genética dos parentais, seu fenótipo geral e seu desempenho em diversos ambientes.

2. O desenvolvimento de um esquema de seleção para caracteres simples e múltiplos que incorpore um ciclo mais rápido de identificação de linhagens elite; seleção e recombinação.

3. A investigação da importância relativa da dominância e da epistasia, particulamente como elas afetam a heterose.

4. O desenvolvimento de caminhos para manipular as interações $\mathrm{G} \times \mathrm{E}$, aumentando desse modo a herdabilidade.

5. A alocação adequada de recursos com respeito a testes preliminares em relação aos avançados.

Para se satisfazer os itens acima mencionados é necessário um conhecimento de como os genótipos interagem com os ambientes. Avaliações estatísticas adequadas são necessárias para que a interação $\mathrm{G}$ x E seja detectada e mensuradas com maior precisão; para tanto, trabalhos têm sido realizados para definir qual a melhor metodologia.

A existência de interações significativas entre genótipos e ambientes pode dificultar a análise genética, por confundir estimativas de parâmetros genéticos e estatísticos e, com isso, complicar as estratégias de seleção e testes. Para se tomar decisão em um programa de seleção é necessário um completo entendimento da interação $\mathrm{G} \times \mathrm{E}$, além do fato de que comumente os melhoristas estão interessados em associar mais de um caráter numa progênie. Nesse sentido, Kroonenberg \& Basford (1989) propuseram uma técnica para explorar a interação entre vários caracteres de genótipos de soja com os ambientes, fornecendo uma descrição geral de padrões básicos presentes nos dados em termos de interações de três fatores (caracteres, genótipos e ambientes) envolvidos. 
Análises padrões de variância padrão conseguem detectar muitas diferenças significativas e a existência de interação, mas não fornecem informações específicas sobre os padrões de resposta; desse modo, a proposta da maioria dos autores é uma técnica complementar descrevendo a contribuição dos diversos caracteres na diferenciação dos genótipos (ou grupos de genótipos) e permitindo ao melhorista integrar um padrão de resposta básico num conjunto de dados de uma maneira direta e racional.

Sem dúvida, o efeito do ambiente em muitos casos não pode ser separado dos demais, atrapalhando a precisão das análises estatísticas. Existem três alternativas para contornar esse problema:

1. Melhorar as técnicas experimentais com parcelas maiores, maior uniformidade do solo, melhor uniformidade de manejo com regulagem adequada dos diversos equipamentos utilizados.

2. Maior número de repetições ou distribuição das repetições, como a distribuição em blocos, o uso de blocos aumentados, entre outras alternativas.

3. Melhorar a análise estatística, pois análises estatísticas efetivas podem filtrar a dispersão do padrão dos dados coletados, resultando em maior precisão.

As duas primeiras opções envolvem maior área e custo econômico, enquanto a terceira envolve apenas melhores estimativas por modelos matemáticos, todavia, que com o aumento das duas primeiras, a precisão da terceira será melhor.

Os números de experimentos a serem realizados para se obter dados sobre o comportamento de genótipos de soja também representa uma informação útil ao melhorista, de modo a possibilitar um melhor emprego dos recursos econômicos e de mão-de-obra disponíveis. Analisando as diferenças entre 43 experimentos de avaliação de linhagens de soja em 16 locais do Estado de Minas Gerais, em comparação a apenas duas localidades e três épocas de semeadura, para a produtividade de grãos, adaptabilidade e estabilidade fenotípica, Sakiyama et al. (1988) obtiveram resultados que indicam uma boa eficiência do uso de apenas dois locais e três épocas. Tais resultados facilitam a execução do programa de melhoramento, pois diminuem o número elevado de linhagens a serem avaliadas em experimentos preliminares, além de reduzir o número de locais. Estes 
resultados são válidos desde que baja uma escolha adequada de linhagens ou genótipos a serem conduzidos, sendo que para novas localidades estudos devem ser realizados.

Aparentemente, os genótipos altamente produtivos são mais sensíveis às variações ambientais, fato observado por Dashiell et al. (1994) em genótipos de soja cultivados em cinco locais na Nigéria, onde a alta interação $\mathrm{G} \times \mathrm{E}$ influenciou também na baixa herdabilidade da produtividade de grãos. Rocha \& Vello (1999), avaliando linhagens de soja com diferentes ciclos de maturação em três locais, observaram efeito de locais em todos os ciclos de maturação, evidenciando a existência da interação $\mathrm{G} \times \mathrm{E}$.

Embora várias metodologias tenham sido propostas ao longo dos últimos trinta anos, visando suavizar os desafios impostos pela interação $\mathrm{G} \times \mathrm{E}$, os pesquisadores atuais continuam buscando instrumentos estatisticos ainda mais efetivos nesta tarefa. Entre os métodos tradicionais, alguns permitem estratificar a população de ambientes em sub-regiões, dentro das quais a interação não se mostre significativa (zoneamento agronômico), permitindo, assim, recomendações regionalizadas (Brasil, 1990; Duarte \& Zimmermann, 1991). Outros métodos procuram identificar os genótipos que menos contribuem para a interação (genótipos estáveis) e que poderiam ser recomendados para toda a populaçào de ambientes, desde que mostrem também uma perfomance média desejável. Neste última categoria são de maior uso os métodos de regressão linear simples e múltipla (Eberhart \& Russel, 1966; Cruz et al. 1989; Brasil, 1990). Apesar do emprego generalizado, os métodos baseados em regressão possuem limitações que têm sido freqüentemente relatadas na literatura (Duarte \& Vencovsky, 1998). 


\section{MATERIAL E MÉTODOS}

\subsection{Material genético}

O material genético envolvido nesta pesquisa compreendeu 33 progênies na geração $F_{11: 4}$, pré-selecionadas na geração $F_{9: 4}$ de 15 cruzamentos de soja. Foram empregadas quatro testemunhas comuns: IAC PL-1, Tamba, Céu Azul e Nimame; estas foram escolhidas por serem apropriadas ao consumo humano direto, sendo caracterizadas como cultivares de soja tipo alimento com sementes grandes, com finalidades culinárias diferenciadas. O cultivar IAC PL-1, desenvolvido pelo Instituto Agronômico de Campinas, se destina a uso geral; Tamba é um cultivar japonês, bem adaptado no Brasil, geralmente colhido na fase madura e usado para processamento de doces especiais; Céu Azul (cultivar brasileiro) e Nimame (cultivar japonês) se destinam especificamente ao consumo na forma de edamame. A identificação de todos os tratamentos é apresentada na Tabela 5.

As 33 progênies foram pré-selecionadas de cruzamentos envolvendo 41 linhagens exóticas de sementes grandes (soja tipo alimento) com dois parentais adaptados (Doko e FT-2) apresentando sementes de tamanho médio (tipo grão). As linhagens tipo alimento participaram como parentais femininos, contribuindo, portanto, também com o citoplasma para os híbridos obtidos.

Os parentais masculinos utilizados foram dois cultivares brasileiros tipo grão (Doko e FT-2), ambos com alta qualidade fisiológica de sementes, produtividade de grãos relativamente alta nos locais em que são recomendados, além de apresentarem 
divergência genética relativamente alta entre eles, conforme os coeficientes de parentesco estimados nas análises de genealogia por Vello et al. (1988).

A geração $F_{2}$ foi avaliada por Destro (1991), a geração $F_{3}$ por Pacova (1992), as gerações $F_{4}$ e $F_{5: 4}$ por Yokomizo (1994) e a geração $F_{9: 4}$ por Yokomizo (1999).

\subsection{Ambiente experimental}

A pesquisa foi conduzida em áreas experimentais do Departamento de Genética/ESALQ/USP, em Piracicaba, localizada a $2^{\circ} 42^{\prime} 33^{\prime \prime}$ de latitude Sul e $47^{\circ} 38^{\prime} 00^{\prime \prime}$ de longitude Oeste e a $540 \mathrm{~m}$ de altitude. Foram considerados como ambientes dois locais:

1. ESALQ, com semeadura em 9 de novembro de 1998;

2. Anhembi, com semeadura em 24 de novembro de 1998.

O local ESALQ possui relevo muito ondulado, artificialmente amenizado com o uso de curvas de níveis e terraços de retenção e solo tipo terra roxa estruturada eutrófica. Localiza-se na área experimental do Departamento de Genética, dentro da sede ESALQ.

O local Anhembi corresponde à Estação Experimental Anhembi, distante cerca de $60 \mathrm{~km}$ da sede ESALQ, possui relevo plano e solo tipo aluvial distrófico, com textura médio-arenosa. Representa um tipo de solo comumente encontrado nos cerrados brasileiros, tendo a acidez neutralizada pela aplicação de calcário dolomítico nos anos anteriores aos experimentos.

Dados fornecidos pelo Departamento de Física e Meteorologia da ESALQ/USP, referentes às médias e totais de insolação, precipitação, umidade relativa, vento máximo, vento médio, temperaturas máxima, mínima e da evaporação durante as fases experimentais, entre Novembro de 1998 e Maio de 1999, encontram-se no Apêndice 1. 


\subsection{Delineamento experimental}

Os experimentos foram conduzidos em condições de campo no delineamento de blocos ao acaso, com duas repetições estratificadas em conjuntos com testemunhas comuns. Cada repetição foi formada por dois conjuntos experimentais contendo 16 e 17 progênies experimentais e quatro testemunhas em cada um. A parcela experimental foi constituída por três fileiras de três plantas, compreendendo um total de nove covas de plantas individuais espaçadas $0,80 \mathrm{~m}$ entre e dentro de cada fileira: desta forma, a área total da parcela correspondeu a $2,40 \mathrm{~m} \times 2,40 \mathrm{~m}$, ou $5,76 \mathrm{~m}^{2}$. Portanto, foram avaliadas até 36 plantas de cada progênie e até 72 plantas de cada testemunha, totalizando 1476 plantas nos dois experimentos.

\subsection{Caracteres avaliados}

Foram avaliados cinco caracteres qualitativos para identificação das progênies e 18 caracteres quantitativos para análise. Todas as observações foram feitas em plantas individuais.

\subsubsection{Caracteres qualitativos avaliados}

CF - Cor da flor: roxa ou branca;

CV - Cor da vagem: cinza ou marrom;

CP - Cor da pubescência: cinza ou marrom;

CS - Cor do tegumento da semente: amarelo, marrom, verde ou preto;

CH - Cor do hilo: creme, marrom, cinza, preto ou sela.

\subsubsection{Caracteres quantitativos avaliados}

Os dados experimentais foram testados pelo módulo SAS/Lab do Programa SAS quanto à necessidade e o tipo de transformação para obtenção de homogeneidade de variâncias residuais e distribuição normal. A seguir são identificados os caracteres e o tipo de transformação realizada nos dados de cada caráter: 
NDF - número de dias para o florescimento, contado desde a emergência até o início do florescimento (estádio $R_{1}$ da escala de Fehr \& Caviness, 1977), transformado em $1 / \sqrt{x}$;

APF - altura da planta no florescimento, em centímetros;

NDM - número de dias para a maturidade, contado desde a emergência até a maturidade (estádio $\mathrm{R}_{8}$ da escala de Fehr \& Caviness, 1977);

APM - altura da planta na maturidade, em centímetros, transformado em $x^{2}$;

PR - período reprodutivo, contado desde o estádio $R_{1}$ até o estádio $R_{8}$, em dias, transformado em $x^{1,4}$;

DAP - diferença na altura da planta durante o período reprodutivo (estádio $R_{1}$ até $o$ estádio $\mathrm{R}_{8}$ ), em centímetros, transformado em $x^{0,4}$;

AC - acamamento, avaliado na maturidade por escala de notas visuais, variando de nota 1 (planta ereta) até 5 (planta totalmente deitada), transformada em $1 / \sqrt{x}$;

VA - valor agronômico, avaliado na maturidade, correspondendo a um índice global incluindo número de vagens, vigor geral da planta, sanidade, retenção de folhas, presença/ausência de haste verde; utilizou-se uma escala de notas visuais variando de nota 1 (planta ruim) até 5 (planta ótima), transformada em $x^{1,3}$;

LVV - largura visual das vagens maduras, através de uma escala de notas, variando de nota 1 (vagens muito estreitas) até 5 (vagens muito largas) (Apêndice 2);

PG - produtividade de grãos maduros em plantas individuais, em gramas/planta, transformada em $\sqrt{x}$; 
PCS - peso de cem sementes maduras em plantas individuais, avaliado através de uma amostra de cem sementes normais de cada planta colhida, em gramas, transformada em $x^{0,8}$;

\%OL - teor de óleo (\%) nas sementes produzidas em plantas individuais, obtido através de espectrofotômetro de ressonância nuclear magnética (NMR), transformada em $x^{2,5}$;

PO - produtividade de óleo em plantas individuais, obtido multiplicando-se o teor de óleo pela produtividade de grãos de cada planta, em gramas/planta, transformada em $x^{2,7}$;

NTV - número total de vagens maduras produzidas em plantas individuais;

$\%$ V1 - porcentagem de vagens maduras com uma semente em uma amostra de 100 vagens retiradas ao acaso, produzida em plantas individuais, transformada em $\sqrt{x}$

\%V2 - porcentagem de vagens maduras com duas sementes em uma amostra de 100 vagens retiradas ao acaso, produzidas em plantas individuais, transformada em $x^{2}$

\%V3 - porcentagem de vagens maduras com três ou mais sementes em uma amostra de 100 vagens retiradas ao acaso, produzidas em plantas individuais;

PV - produtividade de vagens maduras em plantas individuais, em gramas/planta .

$\mathrm{Na}$ avaliação visual dos caracteres $\mathrm{AC}$, VA e LVV, foram atribuídas notas intermediárias $(1,5 ; 2,5 ; 3,5 ; 4,5)$, sempre que necessário.

Para os caracteres NTV, \%V1, \%V2, \%V3 e PV foram avaliadas até quatro plantas por parcela. 


\subsection{Análises estatístico-genéticas}

As análises estatístico genéticas foram realizadas com o auxílio dos programas computacionais GENES, desenvolvido pela Universidade Federal de Viçosa (Cruz, 1997), e SAS desenvolvido pelo SAS Institute Inc., Carolina do Norte, EUA (USP, 2000).

\subsubsection{Médias e variâncias}

Foram estimadas as médias e as variâncias fenotípicas a partir dos dados obtidos ao nível de plantas individuais (covas) para cada caráter e progênie. A média foi estimada pela divisão da soma dos valores individuais pelo número de plantas por ambiente $(\mathrm{i}=1, \ldots, \mathrm{n}$; sendo $\mathrm{n}=$ até 18 covas para NDF, APF, NDM, APM, PR, DAP, AC, VA, LVV, PG, PCS, \%OL e PO; e $n=$ até oito covas para NTV, \%V1, \%V2, \%V3 e PV); a variância fenotípica média entre covas foi calculada pela soma das variâncias ponderadas pelo número de covas $(i=1, \ldots, n$; sendo $n=$ até nove covas para NDF, APF, NDM, APM, PR, DAP, AC, VA, LVV, PG, PCS, \%OL e PO; e $\mathrm{n}=$ até quatro covas para NTV, \%V1, \%V2, \%V3 e PV) de cada repetição e dividido pelo número total de repetições $(j=2$ repetições).

A variância para cada repetição foi estimada por:

$$
V_{j}=\frac{\sum(y i-\bar{y})^{2}}{n-1}
$$

sendo:

$\mathrm{i}=1, \ldots, \mathrm{n}$; sendo $\mathrm{n}=$ até nove covas para NDF, APF, NDM, APM, PR, DAP, AC, VA, LVV, PG, PCS, \%OL e PO; e $\mathrm{n}=$ até quatro covas para NTV, \%V1, \%V2, \%V3 e PV);

$\mathrm{j}=2$ repetições.

\subsubsection{Análise de variância}

Inicialmente foram obtidas as médias das parcelas, dividindo-se a soma dos valores das plantas pelo número de plantas (até nove), para cada repetição e cada caráter. A partir das médias das parcelas foi realizada a análise de variância por local, 
objetivando-se detectar possíveis diferenças entre as progênies. Estas análises individuais também permitiram a comparação dos quadrados médios dos resíduos dos três locais; admitiu-se um limite máximo dado pelo quociente igual a sete entre o maior e o menor quadrados médios residuais das análises de variância individuais (PimentelGomes, 1991), para uma precisão experimental não discrepante entre os experimentos. Para cada local o modelo adotado foi adaptado de Vencovsky (1992a) e de Cruz \& Regazzi (1994):

$$
Y_{i j k}=\mu+G_{i}+R_{j}+(C / R)_{k j}+e_{i j k}
$$

sendo que:

$\boldsymbol{Y}_{i j k}$; observação referente ao i-ésimo genótipo, na j-ésima repetição e k-ésimo conjunto;

$\boldsymbol{\mu}: \quad$ média geral do caráter;

$\boldsymbol{G}_{\boldsymbol{l}}: \quad$ efeito fixo do i-ésimo genótipo;

$\boldsymbol{R}_{\boldsymbol{j}}$ : efeito aleatório da j-ésima repetição;

$(C / R)_{k j}$ : efeito aleatório do k-ésimo conjunto dentro da j-ésima repetição;

$\boldsymbol{e}_{i j k}$ : erro aleatório.

O seguinte modelo para a análise conjunta nos dois locais foi adotado:

$$
Y_{i j k s}=\mu+G_{i}+L_{s}+R_{j}+(C / R / L)_{k j s}+G L_{i s}+e_{i j k s}
$$

sendo que:

$\boldsymbol{Y}_{i j k}$; observação referente ao i-ésimo genótipo, na j-ésima repetição e k-ésimo conjunto no s-ésimo local;

$\boldsymbol{\mu}: \quad$ média geral do caráter;

$G_{i}: \quad$ efeito fixo do i-ésimo genótipo;

$\boldsymbol{L}_{\boldsymbol{s}}$ : $\quad$ efeito fixo do s-ésimo local;

$\boldsymbol{R}_{\boldsymbol{j}}$ : $\quad$ efeito aleatório da j-ésima repetição; 
$(C / R L)_{k j s}$ : efeito aleatório do k-ésimo conjunto dentro da j-ésima repetição no s-ésimo local;

$\boldsymbol{G L}_{\text {is }}$ : efeito fixo da interação de primeira ordem entre genótipos e locais;

$\boldsymbol{e}_{i j k s}$ : erro aleatório.

Considerou-se o seguinte quadro da análise de variância, com efeitos fixos para locais e genótipos:

\begin{tabular}{|c|c|c|}
\hline FV & $\overline{G L}$ & $\mathrm{E}(\mathrm{QM})$ \\
\hline Locais (L) & L-1 & $\sigma^{2}+\mathrm{G} \sigma_{c}^{2}+\mathrm{CGR}_{\mathrm{l}}$ \\
\hline Genótipos (G) & G-1 & $\sigma^{2}+\operatorname{CLR}_{\mathrm{g}}$ \\
\hline Progênies (P) & P-1 & $\sigma^{2}+\operatorname{CLR}_{p}$ \\
\hline Testemunhas ( $\mathrm{T}$ ) & $\mathrm{T}-1$ & $\sigma^{2}+C L R V_{t}$ \\
\hline P vs T & 1 & $\sigma^{2}+\operatorname{CLR}_{(p v s t)}$ \\
\hline$G \times L$ & $(\mathrm{G}-1)(\mathrm{L}-1)$ & $\sigma^{2}+\mathrm{CR} \mathrm{V}_{\mathrm{gl}}$ \\
\hline$P \times L$ & $(\mathrm{P}-1)(\mathrm{L}-1)$ & $\sigma^{2}+C R V_{p l}$ \\
\hline$T \times L$ & $(\mathrm{~T}-1)(\mathrm{L}-1)$ & $\sigma^{2}+C R V_{t i}$ \\
\hline$(P$ vs $T) \times L$ & $1(L-1)$ & $\sigma^{2}+C R V_{(p v s t) I}$ \\
\hline $\mathrm{C} / \mathrm{R} / \mathrm{L}$ & $(\mathrm{C}-1) \mathrm{RL}$ & $\sigma^{2}+G \sigma_{c}^{2}$ \\
\hline $\mathrm{R} / \mathrm{L}$ & $(\mathrm{R}-1) \mathrm{L}$ & $\sigma^{2}+\mathrm{G} \sigma_{c}^{2}+\operatorname{CLG} \sigma_{r}^{2}$ \\
\hline Resíduo & $\{(\mathrm{R}-1)[(\mathrm{P}-1)+(\mathrm{T}-1)]+(\mathrm{C}-1)(\mathrm{TR}-1)\} \mathrm{L}$ & $\sigma^{2}$ \\
\hline
\end{tabular}

sendo:

C : 1 a 2 conjuntos;

L : 1 a 2 locais;

P : 1 a 33 progênies;

T: 1 a 4 testemunhas;

$\mathbf{R}: 1$ a 2 repetições;

T : 1 a 132 genótipos.

Os demais componentes das fontes de variação foram incluídos no resíduo. 


\subsubsection{Contribuição de cada fonte de variação na diversidade total dos dados para cada caráter}

Para a estimação da contribuição de cada fonte de variação na diversidade total dos dados não foram considerados os efeitos de locais e de repetições dentro de locais. Assim, obteve-se:

$$
R_{l}^{2}=\frac{G L_{l 1} \cdot Q M_{l}}{G L_{i} \cdot Q M_{i}+G L_{j} \cdot Q M_{j}+G L_{k} \cdot Q M_{k}} \cdot 100
$$

sendo:

$\boldsymbol{R}_{l}^{2}$ : contribuição da fonte de variação local na variação total, em porcentagem;

$G L_{\ell}$ : graus de liberdade da fonte de variação a ser avaliada;

$Q M_{\boldsymbol{l}}$ : quadrado médio da fonte de variação a ser avaliada;

$G L_{i}$ : graus de liberdade de tratamentos;

$Q M_{\boldsymbol{l}}$ : quadrado médio de tratamentos;

$\boldsymbol{G} \boldsymbol{L}_{\boldsymbol{j}}$ : graus de liberdade da interação $\mathrm{G} \times \mathrm{E}$;

$Q M_{j}$ : quadrado médio da interação $\mathrm{G} \times \mathrm{E}$;

$G L_{k}$ : graus de liberdade do resíduo;

$Q M_{k}$ : quadrado médio do resíduo.

\subsubsection{Correlações genotípicas e fenotípicas}

Os caracteres foram combinados dois a dois para estimar as correlações genotípicas $\left(\mathrm{r}_{\mathrm{G}}\right)$ e fenotípicas $\left(\mathrm{r}_{\mathrm{F}}\right)$ de Pearson entre eles, para cada grupo de genótipos, ou seja, para o grupo das progênies e para o grupo das testemunhas. Para as correlações genotípicas, as estimativas foram obtidas para os dois ambientes combinados e para as fenotípicas foram obtidas individualmente por local e também com os dois local combinados, conforme as seguintes equações (Vencovsky, 1992b): 
Correlação fenotípica:

$$
r_{F(X Y)}=\frac{C O V_{F(X Y)}}{\sqrt{V_{F(x)} V_{F(y)}}}
$$

sendo:

$r_{F(X Y)}: \quad$ correlação fenotípica entre os caracteres x e y;

$\operatorname{cov}_{F(x, y)}: \quad$ produto médio de tratamentos para os caracteres $\mathrm{x}$ e y envolvidos;

$V_{F(x)}$ e $V_{F(y)}$ : variância fenotípica de tratamentos para os caracteres $\mathrm{x}$ e $\mathrm{y}$, respectivamente.

Correlação genotípica:

$$
r_{G(X Y)}=\frac{C O V_{G(X Y)}}{\sqrt{V_{G(x)} V_{G(y)}}}
$$

sendo:

$r_{G(X Y)}:$ correlação genotípica entre os caracteres x e y;

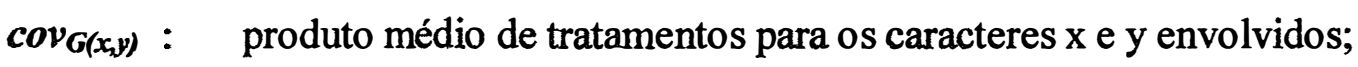

$V_{G(x)}$ e $V_{G(y)}$ : variância genotípica de tratamentos para os caracteres $\mathrm{x}$ e $\mathrm{y}$, respectivamente.

As covariâncias $\left(V_{G(x)}\right.$ e $\left.V_{G(y)}\right)$ foram estimadas a partir da relação:

$$
V_{(x y)}=V_{(x)}+V_{(y)}+2 \operatorname{cov}_{(x+y)}
$$




\subsubsection{Agrupamento de Scott-Knott}

Nos caracteres que apresentaram diferenças estatísticas significativas pelo teste F $(P<0,05)$ optou-se pela aplicação do teste de Scott $\&$ Knott $(1974)$ para cada caráter. Este método classificou em grupos as médias de tratamentos, através das diferenças significativas existentes, sendo indicado para experimentos com elevado número de tratamentos a serem comparados.

O critério de classificação é baseado num processo hierárquico ou de ramificação, dividindo-se as médias de tratamentos em dois grandes grupos e, assim, sucessivamente em novos subgrupos, cada subgrupo deve conter padrões de similaridade em seu conjunto de médias. $O$ processo de divisão é encerrado quando se tenta dividir um subgrupo em dois novos e estes não apresentam diferenças significativas. 


\section{RESULTADOS E DISCUSSÃO}

\subsection{Considerações iniciais}

O ano agrícola de 1998/1999 apresentou íntima associação com o fenômeno climático conhecido como "El Niño", caracterizado para as condições brasileiras por chuvas freqüentes, intensas e associadas a elevadas temperaturas durante os meses de verão (dezembro a março) nas regiões Sul e Sudeste.

Na latitude correspondente a Piracicaba - SP, os meses de dezembro de 1998, janeiro, fevereiro e março de 1999, caracterizaram-se pela ocorrência de chuvas torrenciais, freqüentes e por temperaturas elevadas (Apêndice 1). Estas condições se refletiram no crescimento da soja, obtendo-se plantas altas e vigorosas. Assim houve a necessidade de tutoramento das plantas a fim de se evitar perda de material em contato com o solo.

As mesmas condições ambientais favoreceram a ocorrência do complexo de percevejos (Nezara viridula, Piezodorus guildinii e Euchistos heros) e das chamadas doenças foliares de final de ciclo causadas pelos fungos Septoria glycines e Cercospora kikuchii, ao mesmo tempo em que se foram dificultados os controles químicos e as capinas.

A condução dos experimentos foi normal nos dois locais (Anhembi e ESALQ), permitindo um desenvolvimento vigoroso das plantas, conforme pode ser visualizado pelas médias dos caracteres (Tabela 14).

Foram encontrados comportamentos distintos entre as progênies para diversos caracteres nos dois locais testados (Tabela 14), principalmente para os 
caracteres número de dias para o florescimento (NDF), número de dias para a maturidade (NDM), altura da planta na maturidade (APM), produtividade de grãos (PG), produtividade de óleo (PO), número total de vagens (NTV) e produtividade de vagens (PV). Comparativamente, detectou-se menor variabilidade para os demais caracteres.

Com relação às médias de progênies e testemunhas por local (Tabela 14) para o caráter número de dias para o florescimento (NDF), foram obtidas médias de 64,8 dias em Anhembi e 74,5 dias na ESALQ. Para número de dias para maturidade (NDM), 138,3 dias em Anhembi e 152,0 dias na ESALQ. Para altura da planta na maturidade (APM), 77,5 cm em Anhembi e 67,7 cm na ESALQ. Para produtividade de grãos (PG), 138,6g/planta em Anhembi e 106,9g/planta na ESALQ. Para produtividade de óleo PO, 27,0g de óleo/planta em Anhembi e 20,7g de óleo/planta na ESALQ. Para número total de vagens (NTV), 361,8 vagens/planta em Anhembi e 316,0 vagens/planta na ESALQ. Para produtividade de vagens (PV), 217,2g de vagens/planta em Anhembi e 191,6g de vagens /planta na ESALQ. As testemunhas apresentaram a mesma tendência observada entre as progênies, na comparação entre médias gerais dos dois locais, Anhembi e ESALQ, respectivamente: 60,8 dias e 70,4 dias para NDF; 140,4 dias e 153,9 dias para NDM; 75,2 cm e 64,9 cm para APM; 132,6g e 104,6g para PG; 26,0g de óleo/planta e 19,9g de óleo/planta para PO; 380,6 vagens/planta e 335,3 vagens/planta para NTV e $232,9 \mathrm{~g}$ de vagens/planta e $202 \mathrm{~g}$ de vagens/planta.

Comparando-se os desempenhos em cada local (Tabela 14) observa-se que para os caracteres altura da planta na maturidade (APM), diferença da altura no período reprodutivo (DAP), valor agronômico (VA), produtividade de grãos (PG), produtividade de óleo (PO), número total de vagens (NTV), porcentagem de vagens com uma semente $(\% \mathrm{~V} 1)$, porcentagem de vagens com três ou mais sementes (\%V3) e produtividade de vagens (PV), o local Anhembi foi superior ao local ESALQ, enquanto que para os caracteres número de dias para florescimento (NDF), número de dias para maturidade (NDM), período reprodutivo (PR) e porcentagem de vagens com duas sementes (\%V2), o local ESALQ se mostrou superior; já os caracteres altura da planta no florescimento (APF), acamamento (AC), largura visual de vagens (LVV), peso de cem semente (PCS) 
e porcentagem de óleo nas sementes (\%OL) mostraram comportamentos semelhantes nos dois locais.

Os coeficientes de variação experimental (CV\%) para cada local são apresentados nas Tabelas 9 e 10. Para a maioria dos caracteres avaliados na planta como um todo (NDF, APF, NDM, APM, PR, DAP, VA e PG) os maiores coeficientes foram encontrados na ESALQ, enquanto apenas AC tem maior coeficiente em Anhembi. Para os caracteres de vagem e de grão, como PO, NTV, \%V1, \%V2, \%V3 e PV, os maiores coeficientes foram encontrados na ESALQ, enquanto que LVV e PCS apresentaram maiores $\mathrm{CV} \%$ em Anhembi. Os coeficientes de variação mais altos foram encontrados para os caracteres PO, 46,6\% em Anhembi e 50,7\% na ESALQ; para \%V3, 21,83\% em Anhembi e 29,16\% na ESALQ; para NTV, 18,21\% em Anhembi e 25,1\% na ESALQ; para PV, 18,2\% em Anhembi e 24,3\% na ESALQ; para APM, 19,8\% em Anhembi e $21,16 \%$ na ESALQ.

Os coeficientes de variação dos caracteres NDM, APM, AC, VA e PCS apresentaram valores maiores do que os encontrados por Destro (1991) em $F_{2}$, Pacova

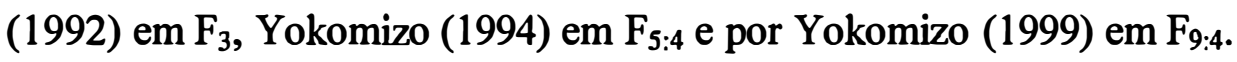

Apesar dos valores altos dos coeficientes de variação em alguns caracteres, a precisão experimental foi suficiente para detectar diferenças significativas entre as progênies, para todos os caracteres.

\subsection{Análise das testemunhas}

Testou-se a existência do efeito das estratificações das repetições em conjuntos, através da análise de variância, considerando apenas as testemunhas como tratamentos para cada local e depois para os dois locais combinados, com a finalidade de se avaliar a uniformidade ambiental dentro das repetições. Este procedimento tem o objetivo de reduzir o desvio padrão residual, aumentando a precisão experimental (Pimentel Gomes, 1991).

Considerando-se os dois locais separadamente (Tabelas 6 e 7), foram observados efeitos significativos de conjuntos para apenas quatro caracteres: em Anhembi foi encontrado $1 \%$ de significância para NDF, já na ESALQ encontrou-se $1 \%$ 
de significância para NDF e APF e 5\% de significância para VA. Para a análise conjunta (Tabela 8) não foram encontrados efeitos de conjuntos para os 18 caracteres avaliados; este fato, aliado a não deteç̧ão de significância para as interações testemunhas $\mathbf{x}$ conjuntos $(T \times C)$ e para testemunhas $x$ conjuntos $\times$ locais $(T \times C \times L)$, permitem considerar que a estratificação em conjuntos não detectou heterogeneidade dentro das repetições, tornando desnecessário o ajuste das médias dos tratamentos. Yokomizo (1999) utilizando o mesmo delineamento também não encontrou heterogeneidade dentro das repetições.

\subsection{Análise de variância para os genótipos}

\subsubsection{Análise de variância para cada local}

No local Anhembi (Tabela 9) ocorreram diferenças significativas em todos os caracteres quando considerados os genótipos testados (testemunhas + progênies). Considerando-se apenas a fonte de variação progênies, foram encontradas diferenças significativas a $1 \%$ em todos os caracteres avaliados, exceto para AC com diferenças significativas a 5\%. Para as testemunhas, apenas quatro caracteres não apresentaram diferenças significativas: APF, AC, NTV e PV. Comparando-se os dois grupos de genótipos (P vs. T) , foram encontradas diferenças significativas para NDF, APF, APM, $P R$ e \%V3; para os demais caracteres, não foram encontradas diferenças significativas, indicando que o comportamento foi similar entre os dois grupos.

No local ESALQ (Tabela 10) ocorreram diferenças significativas para todos os caracteres, exceto VA, quando considerados os genótipos testados. Considerando-se apenas a fonte de variação progênies, foram encontradas diferenças significativas a $1 \%$ em todos os caracteres avaliados, exceto para AC com significância a 5\%. Para as testemunhas, seis caracteres não apresentaram diferenças significativas, NDF, APF, AC, NTV, \%V3 e PV. Comparando-se os dois grupos de genótipos (P vs. T), foram encontradas diferenças significativas para NDF, APM, PR, \%V1 e \%V3; para os demais caracteres, não foram detectadas diferenças significativas, indicando que $o$ comportamento foi similar entre os grupos de genótipos. 
Os resultados observados para os caracteres NDM, APM, AC, LVV, PG e PCS, foram semelhantes aos encontrados por Pacova (1992) em $F_{3}$, Yokomizo (1994) em $\mathrm{F}_{5: 4}$ e Yokomizo (1999) em $\mathrm{F}_{9: 4}$; estes autores encontraram diferenças significativas entre os genótipos, tanto entre progênies quanto entre testemunhas.

\subsubsection{Análise de variância conjunta}

Segundo Pimentel Gomes (1991) quocientes obtidos da relação entre o maior e menor quadrado médio dos resíduos das análises individuais dos caracteres avaliados devem ser menores que sete para se ter um nível adequado de precisão experimental entre os ambientes, e assim, poder dispensar a necessidade de ajuste nos graus de liberdade. Para os caracteres avaliados foi encontrado o valor máximo de 2,80 (Tabela 12), indicando uma boa precisão experimental e, portanto sem a necessidade de ajustes para a análise conjunta.

$\mathrm{Na}$ análise de variância conjunta (Tabela 11), o grupo de progênies mostrou valores significativos a nível de $1 \%$ para o teste $\mathrm{F}$, para todos os caracteres avaliados, indicando a existência de variabilidade entre as progênies testadas.

Para o grupo de testemunhas houve diferenças significativas a nível de $1 \%$ para o teste F, para todos os caracteres, exceto para APF, AC, NTV e PV. Isto indica a existência de diferenças entre as testemunhas utilizadas, o que é esperado, uma vez que apesar de serem soja do tipo alimento foram desenvolvidas com características distintas para utilizações culinárias diversas.

$\mathrm{Na}$ comparação entre os grupos ( $\mathrm{P}$ vs. $\mathrm{T}$ ), os caracteres NDM, AC, VA, LVV, PCS, \%OL, PO, NTV, \%V2 e PV não apresentaram significâncias; o caráter DAP apresentou significância a 5\%, os demais 7 caracteres apresentaram significância a nível de1\%.

Para poucos caracteres a interação progênies $\mathrm{x}$ locais $(\mathrm{P} \times \mathrm{L})$ foi significativa (Tabela 11). Diferenças significativas a 1\%, ocorreram somente para os caracteres NDF, APF, APM, PR, \%V1 e \%V3, e a 5\% apenas em DAP; os demais 11 caracteres não apresentaram interação significativa. As testemunhas apresentaram maior estabilidade do que as progênies: significância de $1 \%$ foram detectadas apenas para NDF e DAP, e a 
5\% para os caracteres APF, NDM e PO; os demais 13 caracteres não apresentaram interação. As testemunhas interagiram com os locais em menor intensidade que as progênies, provavelmente porque elas foram mais testadas para esta finalidade.

Em relação às testemunhas, os cultivares IAC PL-1 e Céu Azul foram desenvolvidos para uso geral, não apenas como alimento, apesar de apresentarem sementes grandes. $\mathrm{O}$ cultivar Tamba, com sementes pretas grandes, foi desenvolvido para consumo de grãos maduros para produção de doces, enquanto Nimame foi desenvolvido especificamente para consumo na forma imatura. Estes dois últimos cultivares são oriundos do Japão, mas já são plantados a muito tempo no Brasil e consumidos pela colônia japonesa. Isto pode explicar as variações nos comportamentos das testemunhas para os diversos caracteres testados.

\subsection{Contribuição de cada fonte de variação na diversidade total dos dados para cada caráter}

Considerando-se apenas os quadrados médios dos dados originais das progênies, estimou-se a contribuição percentual de cada fonte de variação na diversidade total, excetuando-se as fontes testemunhas ( $\mathrm{T}$ ) e progênies vs. testemunhas ( $\mathrm{P}$ vs. $\mathrm{T}$ ) (Tabela 9). Isso permitiu estimar a contribuição de cada fonte de variação para o total da diversidade existente.

$\mathrm{Na}$ Tabela 13, observa-se, com exceção de \%V1, que as progênies $(\mathrm{P})$ foram a mais importante fonte de variação para todos os caracteres, variando de $38,9 \%$ a $86,9 \%$. Tanto a fonte de variação locais $(\mathrm{L})$ como a interação locais $x$ progênies $(\mathrm{L} \times \mathrm{P})$, com exceção de \%V1, contribuíram pouco na diversidade geral, variando, respectivamente, de $0,0 \%$ a $40,7 \%$ e de $3,9 \%$ a $42,8 \%$.

Os caracteres como NDF, NDM, VA, PG e PO apresentaram as maiores diferenças para a fonte de variação locais $(\mathrm{L})$; todavia, tais diferenças foram muito menores do que as diferenças entre progênies; provavelmente, isto ocorreu em razão das diferentes condições climáticas, e das diferenças físicas e químicas do solo entre os dois locais. O caráter AC, apesar de sofrer elevada influência ambiental, mostrou um baixo 
valor, devido ao fato de que com as condições da época (excesso de chuva e elevado porte das plantas), ter havido necessidade de tutotamento das plantas, mascarando a maioria das variações existentes em AC. Outros caracteres (APF, APM, NDM, PR, DAP, LVV, PCS, \%OL, NTV, \%V2 e \%V3) mostraram elevado efeito de progênie, mostrando que sofrem menor efeito ambiental.

Os caracteres NDM, VA, AC e PG comportaram-se diferentemente dos encontrados por Yokomizo (1994, 1999), que encontrou locais (L) como a principal fonte de variação. Para os caracteres APM, LVV e PCS, o comportamento foi semelhante ao encontrado por Yokomizo (1994) em $\mathrm{F}_{5: 4}$, mínimo de 70\%, e maiores do que os encontrados por Yokomizo (1999) em $\mathrm{F}_{9: 4}$, mínimo de 50\%.

A interação locais x progênies ( $\mathrm{L} \times \mathrm{P}$ ) manifestou-se com maior intensidade no caráter \%V1 com 42,8\%. Yokomizo (1994), trabalhando com a geração $F_{5: 4}$, encontrou maior interação para os caracteres AC e PG, enquanto Yokomizo (1999), trabalhando na geração $F_{9: 4}$, encontrou as maiores interações nos caracteres NDM e PCS. Os valores agora encontrados em $F_{11: 4}$ para a interação nestes caracteres foram menores do que os obtidos nos trabalhos anteriormente citados.

\subsection{Médias, desvios padrões e desempenho das progênies em relação às médias das testemunhas}

Na discussão das médias e dos desvios padrões são utilizados os dados originais (não transformados) (Tabelas 15).

Para a discussão do desempenho das progênies em relação às médias das testemunhas foram utilizados os dados transformados (Tabela 16). Isto permite a observação de porcentagem da superioridade ou inferioridade de cada progênie em relação ao padrão de comparação empregado.

As progênies são apresentadas na forma de números ( $\left.\begin{array}{lll}1 & \text { a } & 33\end{array}\right)$, cuja identificação encontra-se na Tabela 5. 


\subsubsection{Caracteres relacionados ao ciclo da planta}

Em relação ao caráter NDF, as progênies variaram de 57 a 78 dias (média de 69,1 dias), sendo que a maioria delas mostrou-se mais tardia que a média das testemunhas (65,6 dias); apenas seis progênies (18,18\%) mostraram-se mais precoces: n. ${ }^{\circ} 21$ (64,7 dias), 27 (61,2 dias), 11 (60,7 dias), 22 (58,7 dias), 15 (58,6 dias) e 9 (57,0 dias). As progênies mais tardias foram as de $n^{\circ}{ }^{\circ} 29$ (78,5 dias), 25 (77,7 dias), 23 (76,7 dias) e 6 (75,8 dias). Considerando-se apenas os cruzamentos com Doko, parental de 32 das 33 progênies avaliadas neste trabalho, Destro (1991) obteve na geração $F_{2}$, variação entre 34,3 a 47,9 dias (média de 39,2 dias); já Pacova (1992) obteve na geração $F_{3}$, variação de 33,7 a 45,2 dias no NDF (média de 38,88 dias). Destro (1991), na geração $\mathrm{F}_{2}$, sugeriu que o controle do período juvenil longo, presente no cultivar Doko, tem controle poligênico; Buzzel \& Voldeng (1980), Kiihl \& Garcia (1989), Hinson (1989) e Sinclair \& Hinson (1992) consideram um controle por poucos genes recessivos. A herança recessiva possibilitou a seleção de progênies com período juvenil mais longo nas gerações subsequentes de endogamia. Quanto aos desvios padrões, as progênies variaram de 2,58 a 9,71, mostrando ainda haver genótipos segregantes para este caráter dentro das progênies.

Comparando-se o desempenho em cada local em relação à média das testemunhas (Tabela 16), verifica-se que 12 das 66 progênies $(18,2 \%)$ apresentaram valores mais tardios de NDF (n. ${ }^{\circ}$ 9, 12, 14, 15, 18, 19, 21, 22, 24, 25, 27 e 30). Na maioria dos casos, as progênies atingiram o NDF mais tardiamente em Anhembi $(60,7 \%)$ do que na ESALQ (39,4\%). Em Anhembi, apenas quatro progênies tiveram desempenhos superiores a 15\%: n. ${ }^{\circ} 29$ (19,1\%), 25 (17,7\%), $23(16,74 \%)$ e $6(15,3 \%)$; já na ESALQ, sete progênies tiveram o mesmo desempenho: n. 8 (16,1\%), $9(15,7 \%), 16$ (16,4\%), 26 (16,9\%), 28 (18,9\%), 32 (18, 5\%) e 33 (15,8\%).

Para o caráter NDM, as progênies variaram de 123 a 162 dias (média de 145,3 dias), sendo que a maioria mostrou-se mais tardia que a média das testemunhas (147,1 dias) (Tabela 15). Um total de 16 progênies (48,5\%) mostraram-se mais precoces que a média das testemunhas: $\mathrm{n}^{\circ} 2,3,9,11,12,14,15,16,18,20,21,22,27,28,32$ e 
33. Das progênies avaliadas, dez apresentaram valores de NDM superiores a 150 dias: n. 29 (162,4 dias), 10 (159,9 dias), 5 (157,9 dias), 31 (157,9 dias), 6 (156,3 dias), 23 (155,3 dias), 19 (155,1 dias), 4 (154,7 dias), 7 (154,4 dias) e 30 (151,5 dias) e quatro progênies apresentaram valores inferiores a 130 dias: $n .^{\circ} 15$ (129,4 dias), 14 (125,7 dias), 9 (123,9 dias) e 22 (123,4 dias). As estimativas encontradas são mais elevadas do que aquelas encontradas por Destro (1991) em $F_{2}$, com variação de 88 a 105 dias (97,0 dias); por Pacova (1992) em $\mathrm{F}_{3}$, com variação de 87,4 a 103,1 dias (média 94,5 dias); e por Yokomizo (1999) na geração $\mathrm{F}_{9: 4}$, com variação de 102 a 132 dias (média 120 dias); mas são semelhantes ao encontrado por Yokomizo (1994) na geração $F_{5: 4}$, com variação de 131 a 161 dias (144,9 dias). Além de fatores ambientais (data de semeadura, efeitos de anos e locais) o ciclo também é influenciado pelos genes, especialmente aqueles que controlam o período juvenil longo. Conforme mencionado anteriormente, um controle dado por cerca de três genes recessivos (Kiihl \& Garcia, 1989; Hinson, 1989) pode tornar os genótipos mais tardios, na medida em que se avança as gerações de endogamia do programa.

Comparando-se o ciclo em cada local em relação à média das testemunhas (Tabela 16), verifica-se que 31 das 66 progênies (46,9\%) apresentaram-se mais precoces. Na maioria dos casos, as progênies atingiram o NDM mais tardiamente na ESALQ (51,5\%) do que em Anhembi (48,5\%). Das progênies avaliadas, três foram mais precoces (-10\%) nos dois locais, respectivamente, Anhembi e ESALQ: n. 9 (-15,9\% e 15,6\%), 14 (-16,3\% e -13,0\%) e 22 (-15,9\% e -16,3\%). Nenhuma progênie apresentou ciclo superior a $10 \%$, nos dois locais, mas três progênies apresentaram este desempenho na ESALQ: . $^{\circ} 29$ (13,9\%), 31 (10,3\%) e 10 (10,2\%).

Para o período reprodutivo (PR) (Tabela 15), onde o valor é dado pelo número de dias entre NDF e NDM, as progênies variaram de 59 a 86 dias (média de 75,9 dias) mostrando menor PR que a média das testemunhas (81,4 dias), sendo que sete progênies $(21,2 \%)$ mostraram valores de PR maiores que a média das testemunhas: $n^{\circ} 9$ (81,5 dias), 27 (81,9 dias), 5 (82,3 dias), 8 (82,9 dias), 31 (83,5 dias), 29 (83,9 dias) e 4 (86,3 dias). Outras nove progênies apresentaram valores de PR inferiores a 70 dias: 14 (59,1 dias), 19 (66,2 dias), 22 (66,3 dias), 18 (66,9 dias), 11 (67,0 dias), 3 (67,3 dias), 
12 (68,6 dias), 18 (69,6 dias) e 21 (69,6 dias). As estimativas encontradas são mais elevadas do que aquelas obtidas por Destro (1991) em $F_{2}$, variação de 54 a 65 dias (média 57,2 dias); e por Pacova (1992) em $\mathrm{F}_{3}$, variação de 50,0 a 60,9 dias (média 55,7 dias) .

Comparando-se o PR em cada local em relação à média das testemunhas (Tabela 16), verifica-se que 57 das 66 progênies (86,4\%) apresentaram valores menores. $\mathrm{Na}$ maioria dos casos, o PR das progênies atingiu maiores valores na ESALQ $(54,5 \%)$ em relação a Anhembi (45,5\%). Das 33 progênies, seis tiveram PR inferiores à média das testemunhas nos dois locais, respectivamente, Anhembi e ESALQ: n. ${ }^{\circ} 14(-29,6 \%$ e 25,2\%), 3 (-19,5\% e -15,1\%), 22 (-18,8\% e -18,3\%), 33 (-17,3\% e -11,5\%), 18 (-15,7\% e $-19,8 \%)$ e $11(-15,6 \%$ e $-19,6 \%)$. Apenas a progênie . $^{\circ} 8$ teve PR positivo nos dois locais $(3,2 \%$ e $0,8 \%)$.

\subsubsection{Caracteres relacionado à altura da planta e ao acamamento}

Em relação à APF, a Tabela 15 mostra que as progênies variaram de 40,1 a $85,6 \mathrm{~cm}$ (média de 62,5 cm), sendo que a maioria delas mostrou-se mais alta que a média das testemunhas $(56,5 \mathrm{~cm})$, apenas oito progênies $(27,3 \%)$ mostraram-se mais baixas: n. $^{\circ} 9(40,1 \mathrm{~cm}), 26(44,0 \mathrm{~cm}), 22(44,8 \mathrm{~cm}), 20(47,3 \mathrm{~cm})$, e $27(47,8 \mathrm{~cm})$ e 18 $(54,2 \mathrm{~cm})$. As progênies mais altas foram: . $^{\circ} 6(92,8 \mathrm{~cm}), 17(85,6 \mathrm{~cm}), 24(84,3 \mathrm{~cm}) \mathrm{e}$ $19(79,5 \mathrm{~cm})$.

As médias obtidas de APF são mais elevadas do que aquelas encontradas por Destro (1991) em $F_{2}$, variando de 22,0 a 31,0 cm (média 28,0 cm); e por Pacova (1992) em $\mathrm{F}_{3}$, variação de 33,0 a $58,7 \mathrm{~cm}$ (média 45,3 cm); portanto, as médias foram mais próximas aos valores máximos encontrados dentro dos cruzamentos. Isto indica que foram sendo selecionadas plantas mais altas ao longo das gerações.

Comparando-se o desempenho nos dois locais em relação à média das testemunhas (Tabela 16), verifica-se que 19 das 66 progênies $(28,8 \%)$ apresentaram menor altura. Na maioria dos casos, as progênies atingiram a APF quando estavam mais altas em Anhembi (57,6\%) do que na ESALQ (42,4\%). Das 33 progênies, cinco tiveram menor APF (-10\%) nos dois locais, respectivamente, Anhembi e ESALQ: n. ${ }^{\circ} 9$ (-25,9\% 
e -32,0\%), 20 (-19,1\% e -13,47\%), 22 (-20,9\% e -20,5\%), $26(-17,0 \%$ e $-26,9 \%)$ e 27 (19,6\% e -11,5\%). Das progênies com bom desempenho, seis apresentaram desempenhos superiores a $20 \%$ : n. ${ }^{\circ} 6(69,8 \%$ e 58, 74\%), 24 (62,6\% e 36,0\%), $17(47,1 \%$ e 55,5\%), 23 $(31,6 \%$ e $27,4 \%), 4(25,1 \%$ e $32,1 \%)$ e $5(22,6 \%$ e $32,0 \%)$.

De acordo com a Tabela 15, para APM as progênies variaram de 44,8 a $112,5 \mathrm{~cm}$ (média de 75,5 cm), mostrando-se mais altas que a média das testemunhas $(66,3 \mathrm{~cm})$. Um total de dez progênies $(30,3 \%)$ mostraram plantas mais baixas em relação à média das testemunhas: $\mathrm{n}^{\circ} 9(44,76 \mathrm{~cm}), 26(49,6 \mathrm{~cm}), 22(49,7 \mathrm{~cm}), 20(54,6 \mathrm{~cm}), 27$ $(57,3 \mathrm{~cm}), 2(59,2 \mathrm{~cm}), 18(62,7 \mathrm{~cm}), 15(63,3 \mathrm{~cm}), 31(64,9 \mathrm{~cm})$ e $33(66,2 \mathrm{~cm})$. Cinco progênies ultrapassaram 100,0 cm de altura: n. $^{\circ} 24(104,7 \mathrm{~cm}), 19(108,8 \mathrm{~cm}), 10(108,9$ $\mathrm{cm}), 6(110,9 \mathrm{~cm})$ e $17(112,5 \mathrm{~cm})$. Levando-se em conta apenas cruzamentos com Doko, as estimativas são mais elevadas do que aquelas encontradas por Destro (1991) em $F_{2}$, variação de 20,9 a 44,5 cm (média 28,0 cm); por Pacova (1992) em $F_{3}$, variação de 19,9 a 47,8 cm (média 29,3 cm); e por Yokomizo (1999) em F9:4, com variação de 31,0 a 73,2 cm (48,6 cm); mas foram semelhantes aos valores de APM encontrados por Yokomizo (1994) em $F_{5: 4}$, com variação de 44,0 a 106,0 cm.

Comparando-se o desempenho em cada local em relação à média das testemunhas (Tabela 16), verifica-se que 19 das 66 progênies $(28,8 \%)$ apresentaram menor altura. Na maioria, dos casos as progênies atingiram a APM quando tinham maior altura na $\operatorname{ESALQ~}(57,6 \%)$ do que em Anhembi (42,4\%). Das 33 progênies, quatro tiveram menor altura $(-10,0 \%)$ nos dois locais, respectivamente, Anhembi e ESALQ: . $^{\circ}$ $9(-26,3 \%$ e $-38,9 \%), 20(-19,5 \%$ e $-15,7 \%), 22(-23,7 \%$ e $-26,3 \%)$ e $26(-20,3 \%$ e $30,4 \%)$; por outro lado cinco progênies tiveram maior altura $(50 \%)$ em relação à média das testemunhas: $n .^{\circ} 19(63,7 \%$ e 64,6\%), 24 (61,2\% e 54,7\%), $17(60,9 \%$ e $79,0 \%)$ e 10 $(55,4 \%$ e $73,6 \%)$.

A DAP, medida entre a altura da planta no florescimento (APF) e a altura da planta na maturidade (APM), pode indicar o tipo de crescimento das progênies avaliadas. A Tabela 15 indica que para o DAP as progênies variaram de 5,6 a 48,1 cm (média de 13,9 cm) mostrando maior crescimento que a média das testemunhas $(10,6$ $\mathrm{cm})$, enquanto que 16 progênies $(48,5 \%)$ mostraram menor crescimento. As cinco 
progênies com menor crescimento foram as de $\mathrm{n}^{\circ} 9(5,6 \mathrm{~cm}), 26(6,3 \mathrm{~cm}), 15(7,3 \mathrm{~cm}), 8$ $(7,4 \mathrm{~cm})$ e $2(7,8 \mathrm{~cm})$. Das progênies avaliadas, seis apresentaram DAP superiores a 20,0 cm de altura: . $^{\circ} 24(20,2 \mathrm{~cm}), 23(21,1 \mathrm{~cm}), 29(23,1 \mathrm{~cm}), 17(26,4 \mathrm{~cm}), 19(28,8 \mathrm{~cm}) \mathrm{e}$ $10(48,1 \mathrm{~cm})$. A progênie $\mathrm{n}^{\circ} 10$ cresceu $48,1 \mathrm{~cm}$, mostrando ter crescimento indeterminado, enquanto as demais progênies podem ser classificadas como de crescimento determinado ou semi-indeterminado.

Comparando-se o desempenho em cada local em relação à média das testemunhas (Tabela 16), verifica-se que 29 das 66 progênies (43,9\%) apresentaram valores menores de DAP. Na maioria dos casos, a DAP das progênies atingiu maiores valores na ESALQ (66,7\%) em relação a Anhembi (33,3\%). Das 33 progênies, quatro tiveram desempenhos inferiores a $-20 \%$ nos dois locais, respectivamente, Anhembi e ESALQ: $n .{ }^{\circ} 26(-39,7 \%$ e $-42,0 \%), 8$ (-31,2\% e -69,0\%) e 2 (-21,0\% e -34,1\%). Além destas, quatro progênies tiveram DAP inferiores a -20\% na ESALQ: n. $^{\circ} 21(-37,6 \%), 22$ $(-33,2 \%), 5(-28,3 \%)$ e $20(-23,4 \%)$ na ESALQ, em relação à média das testemunhas também ocorreram três progênies em Anhembi: n..$^{\circ} 18$ (-56,8\%), 14 (-34,9\%) e 27 (24,2\%). Algumas progênies alcançaram DAP extremamente altos em relação às testemunhas; três atingiram valores superiores a $100 \%$ nos dois locais, respectivamente, Anhembi e ESALQ: n. $^{\circ} 10$ (358,5\% e 352,4\%), 19 (145,8\% e 212,7\%) e $17(117,3 \%$ e 197,86\%). Cinco progênies tiveram desempenho superior a 100,0\% apenas na ESALQ: 23 (111,6\%), 4 (125,7\%), 3 (126,5\%), 6 (175,5\%) e 29 (177,3\%).

Para AC (Tabela 15), as notas das progênies variaram de 1,14 a 2,58 (média de 1,91$)$ mostrando maiores valores que a média das testemunhas $(1,80)$. Um total de 11 progênies $(33,3 \%)$ mostraram menores valores. Das progênies avaliadas, três receberam notas menores que 1,50: . $^{\circ} 26(1,14), 27(1,40)$ e $2(1,41)$; outras três receberam notas iguais ou superiores a 2,50: $\mathrm{n}^{\circ} 13(2,50), 17(2,56)$ e $24(2,58)$; valores altos de $\mathrm{AC}$ indicam a necessidade de se observar as progênies quanto à possível tendência ao acamamento, em futuros testes agronômicos. A necessidade de tutoramento das plantas pode ter mascarado parte da variação que poderia existir entre as progênies. As notas coletadas foram semelhantes a Yokomizo (1994) em $F_{5: 4}$, variação de 1,36 a 2,75; mas são inferiores a Yokomizo (1999) em $\mathrm{F}_{9: 4}$, variação de 1,66 a 3,78, onde os ambientes 
Piracicaba-verão e Piracicaba-outono podem ser considerados estressantes para este caráter, enquanto Anhembi-verão apresentou valores pouco superiores aos encontrados.

Comparando-se o desempenho em cada local em relação à média das testemunhas (Tabela 16), verifica-se que 28 das 66 progênies $(42,4 \%)$ apresentaram valores maiores de $\mathrm{AC}$. Na maioria dos casos, o $\mathrm{AC}$ das progênies atingiu maior valor na ESALQ (69,7\%) em relação a Anhembi (30,3\%). Das 33 progênies, quatro tiveram desempenhos relativos inferiores a $-20 \%$ nos dois locais, respectivamente, Anhembi e ESALQ: n. 26 (-38,2\% e -35,7\%), 9 (-26,5\% e -27,0\%), $2(-23,1 \%$ e -20,6\%) e 27 ($22,7 \%$ e $-21,9 \%)$. Além destas, três progênies tiveram desempenhos relativos inferiores a $-20 \%$ em Anhembi: n. ${ }^{\circ} 11(-46,5 \%), 7(-26,0 \%)$ e $15(-25,7 \%)$, e três progênies na ESALQ: n. $^{\circ} 28(-24,1 \%), 1(-21,9 \%)$ e 30 (-21,8\%). Algumas progênies alcançaram maior $\mathrm{AC}$ em relação às testemunhas; três atingiram valores relativos superiores a $20 \%$ de AC nos dois locais, respectivamente, Anhembi e ESALQ: n..$^{\circ} 24$ (52,5\% e 32,9\%), 13 $(33,7 \%$ e 43,7\%), 17 (30,1\% e 54,5\%) e $6(23,0 \%$ e 38,9\%). Além destes, três progênies tiveram AC relativo superiores a 20\% em Anhembi: n. 30 (37,0\%), 19 (31,5\%) e 21 (26,5\%); outras seis progênies tiveram AC relativo maiores na ESALQ: n. 23 (43,71), 29 (35,5\%), 22 (33,9\%), 4 (29,3\%), $11(29,3 \%)$ e $15(27,5 \%)$.

\subsubsection{Valor agronômico, produtividade de grãos, vagens e de óleo}

O VA é uma nota aplicada subjetivamente que visa reunir atributos considerados favoráveis na planta como altura da planta, ramificação, acamamento, produtividade de vagens e de grãos, além da sanidade. De acordo com a Tabela 15, para VA as notas das progênies variaram de 2,13 a 3,34 (média de 2,86) mostrando valores maiores que a média das testemunhas $(2,77)$, sendo que 11 progênies $(33,3 \%)$ mostraram valores menores de VA que a média das testemunhas. Foram encontradas 11 progênies com notas de VA superiores a 3,0: n. $29(3,41), 18(3,34), 19(3,28), 23(3,27), 13$ $(3,25), 5(3,15), 7(3,15), 4(3,12), 17(3,11), 16(3,07)$ e $32(3,01)$. Destas progênies, três são originárias do cruzamento Late Giant x Doko (n. ${ }^{\circ} 13,16$ e 17) e duas do cruzamento Japão 1 x Doko (n. ${ }^{\circ} 18$ e 19). As notas foram superiores a aquelas observadas em cruzamentos com Doko por Destro (1991), variação de 1,43 a 2,41 
(média de 1,87) em $F_{2}$; Pacova (1992), variação de 1,51 a 2,39 (média de 1,94) em F ; Yokomizo (1994), variação de 1,80 a 2,96 em F5:4; e Yokomizo (1999), variação de 1,43 a 2,10 em F9:4, incluindo o ambiente estressante Piracicaba-outono, e de 1,79 a 2,80, sem considerar este ambiente. Estes valores mostram que a seleção ao longo do tempo tem sido efetiva na escolha e na melhoria das progênies para VA.

Comparando-se o desempenho em cada local em relação à média das testemunhas (Tabela 16), verifica-se que 28 das 66 progênies $(42,4 \%)$ apresentaram valores menores de VA. Na maioria dos casos, o VA das progênies atingiu maior valor na ESALQ (51,5\%) em relação a Anhembi (48,5\%). Das 33 progênies, apenas três tiveram desempenhos relativos inferiores a $-10 \%$ nos dois locais, respectivamente, Anhembi e ESALQ: $n .{ }^{\circ} 9$ (-17,6\% e -26,8\%), 26 (-13,2\% e -34,6\%) e 27 (-13,0\%\% e $10,9 \%)$. Além destas, três progênies tiveram desempenhos relativos inferiores a $-10 \%$ em Anhembi: n. ${ }^{\circ} 22$ (-11,8\%), $6(-10,4 \%)$ e 31 (-10,3\%), outras quatro progênies mostraram-se inferiores na ESALQ: . $^{\circ} 1$ (-24,8\%), 2 (-17,9\%), 11(-12,28) e 8 (-11,8\%) na ESALQ. Das progênies com valores relativos superiores de VA, seis progênies atingiram desempenhos superiores a $10 \%$ nos dois locais, respectivamente, Anhembi e ESALQ: . $^{\circ} 18$ (29,2\% e 10,5\%), 29 (24,6\% e 21,1\%), 13 (17,6\% e 16,9\%), 23 (15,7\% e 20,8\%), 5 (14,8\% e 12,1\%) e 7 (12,0\% e 15,9\%). Além destas, apenas a progênie n. ${ }^{\circ} 11$ teve desempenho relativo superior a $20 \%$ em Anhembi (34,4\%); já na ESALQ, três progênies atingiram $20 \%$ de desempenho relativo: $n^{\circ} 19(35,2 \%), 17(23,0 \%)$ e 31 $(21,3 \%)$.

A PG é uma característica importante para os programas de melhoramento de soja tipo grão, como também é importante em programas de no melhoramento da soja tipo alimento. A Tabela 15 mostra que a produtividade das progênies variou de 67,7 a $177,9 \mathrm{~g} /$ planta (média de 124,2g/planta), valores estes relativamente altos quando comparados com a média das testemunhas $(118,6 \mathrm{~g} / \mathrm{planta})$. Um total de 14 progênies $(42,4 \%)$ apresentaram menores valores de PG. Entre as progênies avaliadas, nove mostraram PG acima da melhor testemunha IAC PL-1 (137,9g/planta); cinco progênies ultrapassaram a PG de 150,0g/planta:.$^{\circ} 13$ (177,9g/planta), 17 (174,1g/planta), 12 (167,9g/planta), 24 (160,6g/planta) e $16(156,4 \mathrm{~g} /$ planta); com exceção da progênie 24 , as 
demais quatro progênies são originárias do cruzamento Late Giant x Doko. Das progênies menos produtivas apenas quatro tiveram PG inferiores a 100,0g/planta: $n .^{\circ} 29$ (98,8g/planta), 27 (89,6g/planta), 15 (86,9g/planta) e 4 (86,3g/planta). As produtividades obtidas foram muito superiores a aquelas coletadas em cruzamentos com Doko por Destro (1991) em $\mathrm{F}_{2}$, variação de 18,6 a 36,2g/planta (média 25,7g/planta); por Pacova (1992) em $\mathrm{F}_{3}$, variação de 17,9 a 49,57g/planta (média de 36,9g/planta); Yokomizo (1994) em $F_{5: 4}$, variação de 20,9 a 71,6g/planta; Yokomizo (1999) em $F_{9: 4}$, variação de $36,8 \mathrm{~g}$ a 102,0g/planta, incluindo o ambiente estressante Piracicaba-outono, e de 37,3g a $135,9 \mathrm{~g} /$ planta, sem considerar este ambiente.

Comparando-se o desempenho em cada local em relação à média de PG das testemunhas (Tabela 16), verifica-se que 31 das 66 progênies (46,9\%) apresentaram menor produtividade. Na maioria dos casos a PG das progênies atingiu maiores valores em Anhembi (64,6\%) em relação à ESALQ (36,4\%). Das 33 progênies, apenas quatro tiveram PG relativas inferiores a $-10 \%$ nos dois locais, respectivamente, Anhembi e ESALQ: $n .^{\circ} 1(-41,6 \%$ e $-44,6 \%), 15(-37,2 \%$ e $-13,5 \%), 4(-17,0 \%$ e $-40,3 \%)$ e 27 ($14,9 \%$ e $-36,62 \%)$. Além destas, quatro progênies tiveram PG relativas inferiores a 10\% em Anhembi: n. 9 (-24,6\%), 26 (-14,2\%), 22 (-13,2\%) e $14(-11,4 \%)$; e oito progênies na ESALQ: n. 29 (-42,0\%), 10 (-27,3\%), 32 (-16,4\%), 21 (-15,0\%), 8 (14,5\%), 20 (-11,8\%), $18(-11,7 \%)$ e 30 (-11,1\%) na ESALQ. As melhores seis progênies atingiram valores relativos de PG superiores a $20 \%$ nos dois locais, respectivamente, Anhembi e ESALQ: n. ${ }^{\circ} 13$ (58,7\% e 38,8\%), 12 (51,4\% e 28,9\%), 24 (39,5\% e 30,2\%), $17(33,5 \%$ e 63,6\%), 23 (29,5\% e 30,2\%) e 19 (21,6\% e 12,8\%). Além destas, duas progênies tiveram PG relativas superiores a 20\% em Anhembi: n. 25 (26,7\%) e 2 (20,8\%); outras duas progênies destacaram-se na ESALQ: n. $^{\circ} 16(47,2 \%)$ e 14 (39,8\%).

Os desvios padrões dos caracteres avaliados acima, podem ser considerados altos para progênies em geração $F_{11: 4}$, mostrando a existência de variabilidade. Os valores encontrados para os mesmos caracteres avaliados foram maiores do que os encontrados por Yokomizo (1999) em $\mathrm{F}_{9: 4}$.

A PO foi calculada multiplicando-se o teor de óleo (\%OL) pela produtividade de grãos (PG) de cada planta; assim, a PG apresentando maior 
variabilidade em relação a \%OL é que determinará os valores de PO (Zimback, 1992; Soldini, 1993; Montaño-Velasco, 1994; Farias Neto, 1995; Laínez-Mejía, 1996; Rocha, 1998; Hamawaki, 1998). De acordo com a Tabela 15, a PO das progênies variou de 10,6 a 36,6g de óleo/planta (média de 24,2g de óleo/planta), mostrando valores maiores que a média das testemunhas $(23,0 \mathrm{~g}$ de óleo/planta). Um total de 16 progênies $(48,5 \%)$ mostraram menores valores de PO em relação à média das testemunhas. Entre as progênies avaliadas, seis mostraram PO maior que a testemunha mais produtiva, IAC PL-1 (27,9g de óleo/planta): n. ${ }^{\circ} 13$ (36,6g de óleo/planta), 17 (36,4g de óleo/planta) 12 (33,7g de óleo/planta), 16 (32,7g de óleo/planta), 24 (31,8g de óleo/ planta) e 2 (29,1g de óleo/planta). Destas progênies, quatro são originárias do cruzamento Late Giant x Doko (n. $.^{\circ} 11,12,16$ e 17). Das progênies com menor PO, cinco apresentaram valores inferiores a 20,0 $\mathrm{g}$ de óleo/planta: $\mathrm{n} .^{\circ} 1$ (10,6g de óleo/planta), 4 (14,4g de óleo/planta), 27 (15,54 g de óleo/planta), 15 (16,0g de óleo/planta) e 29 (17,27g de óleo/planta).

Comparando-se o desempenho em cada local em relação à média das testemunhas (Tabela 16), verifica-se que 27 das 66 progênies (40,9\%) apresentaram valores menores. $\mathrm{Na}$ maioria dos casos, a PO das progênies atingiu maior valor em Anhembi (54,5\%) em relação a ESALQ (45,5\%). Das 33 progênies, apenas três tiveram desempenhos relativos menores que $-20 \%$ nos dois locais, respectivamente, Anhembi e ESALQ: $n^{\circ} 1$ (-51,0\% e -58,0\%), 4 (-28,1\% e -48,1\%) e 27 (-24,7\% e -42,5\%). Além destas, três progênies tiveram desempenhos relativos inferiores a $-20,0 \%$ apenas na ESALQ: $n .{ }^{\circ} 29(-48,7 \%)$ e $10(-29,7 \%)$ e $5(24,3 \%)$. Nos melhores desempenhos, sete progênies atingiram valores relativos superiores a $10 \%$ nos dois locais, respectivamente, Anhembi e ESALQ: n. ${ }^{\circ} 13$ (70,8\% e 44,5\%), 12 (54,3\% e 36,7\%), 17 (43,2\% e 78,3\%), 24 (42,1\% e 33,2\%), 16 (32,6\% e 54,9\%), 2 (27,6\% e $24,8 \%)$ e 23 (20,5\% e $21,5 \%)$. Além destas, duas progênies atingiram este desempenho em Anhembi: n. ${ }^{\circ} 19(23,1 \%)$ e 20 (20,1\%), e três progênies na ESALQ: 5 (24,3\%), 11 (22,5\%) e 31 (21,2\%). Quatro das progênies com PO mais alto são originárias do cruzamento Late Giant x Doko (n. ${ }^{\circ}$ $12,13,16,17)$.

A Tabela 15 indica que para NTV o desempenho das progênies variou de 179,7 a 572,5 vagens/planta (média de 349,9 vagens/planta), sendo a média das 
testemunhas 357,9 vagens/planta. Um total de 13 progênies (39,4\%) mostraram maiores produções de vagens. Foram encontradas nove progênies com NTV maiores que a melhor testemunha, Nimame (367,7 vagens/planta): $n .{ }^{\circ} 13$ (572,5 vagens/planta), 17 (517,6 vagens/planta), 11 (448,0 vagens/planta), 28 (446,5 vagens/planta), 12 (410,5 vagens/planta), 14 (406,1 vagens/planta), 31 (387,7 vagens/planta), 5 (380,2 vagens/planta) e 26 (373,8 vagens/planta). Das progênies com menor NTV, cinco apresentaram valores inferiores a 300 vagens/planta: $n 0^{\circ} 1$ (179,2 vagens/planta), 15 (179,7 vagens/planta), 4 (225,8 vagens/planta), 22 (236,8 vagens/planta) e 27 (268,7 vagens/planta). É interessante notar que para NTV, progênies originárias do cruzamento Late Giant x Doko, mostraram-se extremamente produtivas (n. ${ }^{\circ} 11,12,13,14$ e 17), apesar deste cruzamento também incluir uma das progênies menos produtivas ( $\left.\mathrm{n}^{\circ}{ }^{0} 15\right)$.

Comparando-se o desempenho em cada local em relação à média das testemunhas (Tabela 16 ), verifica-se que 38 das 66 progênies $(57,6 \%)$ apresentaram valores menores. Na maioria dos casos, o NTV das progênies atingiu maior valor em Anhembi $(57,6 \%)$ em relação à ESALQ (42,4\%). Das 33 progênies, quatro tiveram desempenhos relativos menores que $-20 \%$ nos dois locais, respectivamente, Anhembi e ESALQ: $n^{\circ} 10(-55,3 \%$ e -28,9\%), 18 (-44,8\% e -48,0\%), $9(-25,5 \%$ e $-48,9 \%)$ e 21 ($21,0 \%$ e $-22,4 \%$ ). Além destas, cinco progênies tiveram desempenhos inferiores a $-20 \%$ em Anhembi: $n .^{\circ} 3$ (-49,5\%), 25 (-40,9\%), 12 (-38,8\%), 7 (-28,2\%) e $6(-24,2 \%)$, outras sete progênies mostraram-se inferiores na ESALQ: n. ${ }^{\circ} 15$ (-55,5\%), 1 (-50,4\%), 4 ($46,8 \%), 27(-34,2 \%), 30(-29,3 \%), 29(-28,1 \%)$ e $22(-25,8 \%)$. Nos melhores desempenhos, apenas uma progênie atingiu valores relativos de NTV superiores a $20 \%$ nos dois locais: n. $^{\circ} 14(30,6 \%$ e 20,8\%). Além destas, seis progênies tiveram desempenho superiores a 20\% em Anhembi: n. ${ }^{\circ} 16$ (39,8\%), 27 (35,2\%), 20 (31,8\%), 15 (27,7\%), 26 (20,8\%), outras seis progênies mostraram-se inferiores na ESALQ: $n .^{0} 13$ (82,8\%), 17 (59,1\%), 7 (37,9\%), 28 (37,7\%), 5 (31,2\%) e 24 (21,4\%).

A Tabela 15 reporta que para produtividade de vagens (PV) das progênies houve variação de $113,0 \mathrm{~g}$ de vagens/planta a $301,1 \mathrm{~g}$ de vagens/planta (média de 208,8g de vagens/planta); a média das testemunhas foi $217,5 \mathrm{~g}$ de vagens/planta. Dez progênies $(30,3 \%)$ mostraram valores relativos menores que a média das testemunhas. Entre as 
progênies avaliadas, cinco mostraram PV acima da melhor testemunha (Céu Azul com $245,4 \mathrm{~g}$ de vagens/planta): $\mathrm{n}^{\circ} 5$ (247,1g de vagens/planta), 12 (277,1g de vagens/planta), 13 (287,9g de vagens/planta), 16 (260,8g de vagens/planta), 17 (301,1g de vagens/planta) e 24 (277,5g de vagens/planta). Destas cinco, quatro progênies se originaram do cruzamento Late Giant $x$ Doko (n. ${ }^{\circ} 12,13,16$ e 17). A progênie n. ${ }^{\circ} 1$ produziu 113,0 g de vagens/planta, produção considerada abaixo de um valor mínimo de $150,0 \mathrm{~g}$ de vagens maduras/planta utilizado como padrão mínimo aceitável.

Comparando-se o desempenho em cada local (Tabela 16), observa-se uma grande amplitude de respostas em relação à média das testemunhas, variação de $-100 \% \mathrm{a}$ $37,9 \%$. Verifica-se que 42 das 66 progênies $(63,6 \%)$ apresentaram valores menores. $\mathrm{Na}$ maioria dos casos, a PV das progênies atingiu maiores valores em Anhembi (51,5\%) em relação a ESALQ (48,5\%). Das 33 progênies, três tiveram desempenhos relativos inferiores a -20\% nos dois locais, respectivamente, Anhembi e ESALQ: n. ${ }^{\circ} 1$ (-44,6\% e $51,9 \%), 22(-37,4 \%$ e $-20,2 \%)$ e $4(-27,4 \%$ e $-30,4 \%)$. Além destas, seis progênies tiveram desempenhos relativos inferiores a $-20 \%$ em Anhembi: $n .^{\circ} 7$ (-100,0\%), 9 ($35,9 \%), 6(-27,3 \%), 15(-27,1 \%), 14(-26,7 \%)$ e $26(-22,3 \%)$; e sete progênies na ESALQ: . $^{\circ} 29$ (-48,9\%), 18 (-37,9\%), 27 (-36,8\%), 8 (-30,2\%), 10 (-28, 2\%), 32 ($26,9 \%)$ e $30(-24,2 \%)$. Considerando-se os melhores desempenhos, três progênies atingiram valores relativos positivos superiores a $20 \%$ nos dois locais, respectivamente, Anhembi e ESALQ: n. $^{\circ} 24$ (32,0\% e 22,5\%), 13 (30,7\% e 34,4\%) e 12 (30,2\% e 24,2\%). Além destas, mais três progênies tiveram desempenhos superiores a 20\% na ESALQ: $n$. ${ }^{\circ}$ $17(61,1 \%), 16(49,4 \%)$ e $5(35,9 \%)$.

\subsubsection{Caracteres relacionados ao tamanho das sementes e tipos de vagens}

A LVV é um caráter em que se mede o tamanho das sementes à partir de uma avaliação visual das vagens de uma planta. Esta metodologia foi desenvolvida por Pacova (1992) e utilizada por Yokomizo (1994), Yokomizo \& Vello (1998) e por Yokomizo (1999). A Tabela 15 reporta que para LVV as notas das progênies variaram de 1,62 a 3,26 (média de 2,79), sendo que a média das testemunhas foi de 2,90. Das 33 
progênies $14(42,4 \%)$ mostraram notas maiores. Foram encontradas 12 progênies com notas superiores a 3,0: n. ${ }^{\circ} 19(3,41), 3(3,26), 30(3,26), 20(3,25), 21(3,24), 16(3,22)$, $10(3,11), 22(3,10), 18(3,09), 12(3,06), 5(3,03)$ e $4(3,01)$; mas nenhuma apresentou nota superior a melhor testemunha (Tamba com 3,55). Cinco progênies obtiveram médias iguais ou inferiores a 2,50: n. ${ }^{\circ} 6(2,50), 7(2,31), 28(2,12), 26(1,90)$ e $14(1,62)$. As notas obtidas foram superiores àquelas coletadas em cruzamentos com Doko, por Pacova (1992), variação de 1,51a 2,28 (média de 1,85) em $F_{3}$; Yokomizo (1994), variação de 1,44 a 3,55 em $F_{5: 4}$; e a Yokomizo (1999), variação de 2,19 a 3,12 em $F_{9: 4}$.

Comparando-se o desempenho em cada local (Tabela 16), em relação à média das testemunhas, verifica-se que 35 das 66 progênies $(53,0 \%)$ apresentaram valores menores. Na maioria dos casos, o LVV das progênies atingiu maiores valores em Anhembi (51,5\%) em relação a ESALQ (48,5\%). Das 33 progênies, sete tiveram desempenhos relativos inferiores de LVV a $-10,0 \%$ nos dois locais, respectivamente, Anhembi e ESALQ: . $^{\circ} 14$ (-51,1\% e -36,9\%), 26 (-40,4\% e -28,4\%), 28 (-23,2\% e $30,1 \%), 8(-20,8 \%$ e $-25,0 \%), 6(-13,4 \%$ e $-13,6 \%), 32$ (-12,7\% e $-11,9 \%)$ e $7(-11,7 \% \%$ e -28,8\%). Além destas, três progênies tiveram desempenhos relativos inferiores a 10,0\% em Anhembi: n. 11 (-56,1\%), 29 (-15,5\%), 31 (-15,1\%) e 33 (-12,1\%); e duas progênies na ESALQ: $n^{\circ} 1(-15,0 \%)$ e $2(-13,5 \%)$. Considerando-se as progênies de maior LVV, apenas a progênie . $^{\circ} 19$ atingiu valor superior a $10,0 \%$ nos dois locais (12,6\% em Anhembi e 22,5\% na ESALQ). Além desta, três progênies tiveram desempenhos relativos superiores a 10,0\% em Anhembi: n. ${ }^{\circ} 20$ (19,2\%), 21 (18,1\%) e 16 (13,3\%), e duas progênies na ESALQ: . $^{\circ} 3$ (17,7\%) e 30 (17,7\%).

O PCS é uma caráter importante para os programas de melhoramento de soja tipo alimento. Isto ocorre porque os tipos hortaliça ou edamame, doce ou kuromame e salada, todos eles incluem preferência por sementes de tamanho grande $(>20,0 \mathrm{~g} / 100$ sementes). A Tabela 15 mostra que o PCS das progênies variou de 17,1 a 25,6g/100 sementes (média de 22,2g/100 sementes); tais valores são relativamente próximos da média das testemunhas $(22,9 \mathrm{~g} / 100$ sementes). Um total de 16 progênies $(48,5 \%)$ mostraram altos valores de PCS, mas apenas a progênie n..$^{\circ} 19$ apresentou PCS superior a $25,0 \mathrm{~g} / 100$ sementes $(25,6 \mathrm{~g} / 100$ sementes). Nenhuma progênie mostrou PCS acima da 
melhor testemunha, Tamba (27,0g/100 sementes). Das piores progênies, apenas cinco mostraram PCS menores que 20g/100 sementes: $\mathrm{n}^{\circ} 14$ (15,2g/100 sementes), 26 (17,1g/100 sementes), 28 (18,6g/100 sementes), 7 (18,8g/100 sementes) e $8(19,2 \mathrm{~g} / 100$ sementes). Os valores de PCS foram superiores a aqueles coletados em cruzamentos com Doko, por Destro (1991) em $F_{2}$, variação de $16,9 g / 100$ sementes a 22,7g/100 sementes (média 20,1g/100 sementes); e por Pacova (1992), variação de 9,8g/100 sementes a $22,7 \mathrm{~g} / 100$ sementes (média $18,7 \mathrm{~g} / 100$ sementes) em $\mathrm{F}_{3}$; todavia, foram inferiores àqueles coletados por Yokomizo (1994), variação de $11,9 \mathrm{~g} / 100$ sementes a 27,9g/100 sementes em $\mathrm{F}_{5: 4}$; e foram semelhantes as estimativas de Yokomizo (1999), variação de $16,7 \mathrm{~g} / 100$ sementes a $26,0 \mathrm{~g} / 100$ sementes em $\mathrm{F}_{9: 4}$.

Comparando-se o desempenho do PCS em cada local em relação à média das testemunhas (Tabela 16), verifica-se que 35 das 66 progênies $(53,0 \%)$ apresentaram valores relativos menores. Na maioria dos casos, os valores de PCS das progênies foram maiores em Anhembi (60,6\%) em relação a ESALQ (39,4\%). Das 33 progênies, seis tiveram PCS relativos inferiores a $-10,0 \%$ nos dois locais, respectivamente, Anhembi e ESALQ: . $^{\circ} 14$ (-39,1\% e -27,9\%), 26 (-27,3\% e -23,1\%), 28 (-15,9\% e -21,4\%), 8 ($15,1 \%$ e $-16,8 \%), 7(-13,5 \%$ e $-22,3 \%)$ e $32(-10,2 \%$ e $-13,7 \%)$. Além destas, duas progênies mostraram PCS relativos inferiores a -10,0\% em Anhembi:.$^{\circ} 11(-34,2 \%)$ e $29(-12,7 \%)$; e somente a progênie $n^{\circ} 1(-11,8 \%)$ na ESALQ. Entre as melhores progênies, nenhuma atingiu valores relativos superiores a 10,0\% nos dois locais; e apenas a progênie $n .^{\circ} 20$ atingiu este desempenho em Anhembi $(10,3 \%)$ e a progênie . $^{\circ}$ 11 na ESALQ (17,4\%).

A \%OL no melhoramento de soja tipo alimento é um fator extremamente importante, pois está relacionada com o sabor e com as características culinárias das sementes, sendo preferido material que contenha baixos teores de óleo nas sementes. A tabela 15 indica que para \%OL, as notas das progênies variaram de 16,7\% a 21,2\% (média de 19,2\%) mostrando valores maiores em relação à média das testemunhas $(19,1 \%)$, um total de 13 das 33 progênies $(39,4 \%)$ mostraram valores menores que a média das testemunhas. Foram encontradas 15 progênies $\left(\mathrm{n}^{\circ}{ }^{\circ} 2,8,11,12,13,14,16,17\right.$, $18,22,26,30,31,32$ e 33) com teores de óleo maiores que a maior testemunha, IAC 
PL-1 (19,8\%) e três progênies (n. $.^{\circ} 1,4$ e 29) com teores de óleo menores que a menor testemunha, Tamba (17,1\%). O maior teor de óleo da testemunha IAC PL-1 em relação às outras testemunhas, provavelmente é devido ao fato desta não ter sido desenvolvida exclusivamente como alimento; tal fato não ocorre com Tamba, desenvolvida para consumo maduro na forma de doce, possuindo, então, baixos teores de óleo e bom sabor, pois elevados teores de óleo sabidamente diminuem a palatabilidade do grão de soja. As notas obtidas foram superiores àquelas coletadas em cruzamentos com Doko por Marega Filho (1999), que trabalhando com progênies de soja tipo alimento em Londrina, obteve variação de $12,0 \%$ a $20,4 \%$ (média $16,6 \%$ ). Em todos cruzamentos comuns a este trabalho e de Marega Filho (1999), como: PI 80.441 x Doko, Late Giant x Doko, Japão 2 x Doko, Aliança Preta x Doko e Tadacha x Doko, os teores de óleo obtidos em Piracicaba foram maiores que os de Londrina. Dados relatados por Howell \& Collins (1957), Teixeira et al. (1979a, 1979b) e Cianzio et al. (1985) mostraram variação nos teores de óleo, proteina, ácidos graxos e carboidratos nas sementes de soja em função da latitude, cultivares, adubação química, anos agrícolas e práticas culturais. Mascarenhas et al. (1981, 1996) e Tanaka et al.(1995) mostraram que o maior teor de óleo é decorrente da interferência da acidez no processo simbiótico de fixação de nitrogênio, pois com o aumento de calcário ocorreu acréscimo no teor de proteínas e um decréscimo nos teores de ácidos graxos componentes do óleo.

Comparando-se o desempenho em cada local em relação à média das testemunhas (Tabela 16), verifica-se que 30 das 66 progênies $(45,4 \%)$ apresentaram valores menores. $\mathrm{Na}$ maioria dos casos, a \%OL das progênies atingiu maior valor em Anhembi (60,6\%) em relação a ESALQ (39,4\%). Das 33 progênies, apenas duas tiveram desempenhos relativos inferiores a $-10 \%$ nos dois locais, respectivamente, Anhembi e ESALQ: . $^{\circ} 4(-13,0 \%$ e $-13,9 \%)$ e $1(-10,3 \%$ e -14,3\%). Além destas, duas progênies tiveram desempenhos relativos inferiores a -10\% em Anhembi: $n^{\circ} 15(-11,9 \%)$ e $6(-$ 10,4\%); outras duas progênies mostraram-se inferiores na ESALQ: 29 (-15,1\%) e 27 ($11,2 \%)$. Nenhuma progênie atingiu valor relativo superior a $10 \%$ nos dois locais; apenas a progênie $n .^{\circ} 22$ atingiu este desempenho relativo na ESALQ $(13,7 \%)$. 
O tipo de vagem produzida pela planta é um fator importante para comercialização da soja tipo edamame (imatura, hortaliça). Vagens vazias ou contendo apenas uma semente depreciam o produto quando comercializadas na forma de vagens presas às hastes ou, então, são descartadas quando embaladas soltas em sacos plásticos ou enlatados. Por isso, prefere-se plantas que produzam o menor número possível de vagens com uma única semente. De acordo com a Tabela 15, a porcentagem de vagens com uma semente (\%V1) nas progênies variou de $9,7 \%$ a $36,5 \%$ (média de $17,8 \%$; abaixo da média das testemunhas, 22,7\%). Apenas três progênies $(9,1 \%)$ mostraram valores maiores: . $^{\circ} 7$ (36,5\%Vl/planta), 29 (24,1\%Vl/planta) e 9 (23,6\%V1/planta). A média geral das testemunhas foi elevada por Tamba, com média muito superior às demais (40,5\%), provavelmente, isto se deve ao fato do cultivar Tamba ser comercializado na forma de grãos maduros, de maneira que não houve seleção quanto ao tipo de vagem. Apenas a progênie n. 14 apresentou \%V1 menor que 10,0\% $(9,7 \% \mathrm{~V} 1 /$ planta $)$.

Comparando-se o desempenho em cada local (tabela 15), observou-se uma grande amplitude de respostas em relação à média das testemunhas, de $-100,0 \%$ a $237,5 \%$. Verifica-se que 61 das 66 progênies $(92,4 \%)$ apresentaram valores negativos para \%V1. Na maioria dos casos, a \%V1 das progênies atingiu maior valor na ESALQ (54,5\%) em relação a Anhembi (45,5\%). Das 33 progênies, dez tiveram desempenhos relativos inferiores a $-30 \%$ nos dois locais, respectivamente, Anhembi e ESALQ: $n .{ }^{\circ} 30$ $(-58,0 \%$ e $-49,4 \%), 13$ (-54,6\% e -37,7\%), 15 (-49,6\% e -39,9\%), 26 (-48,5\% e -36,3\%), $28(-46,8 \%$ e $-34,0 \%), 14(-46,2 \%$ e $-68,9 \%), 4(-36,7 \%$ e $-33,7 \%), 34(-35,8$ e $23,4 \%), 16(-33,6 \%$ e $-38,5 \%)$ e $25(-31,5 \%$ e $-45,95)$. Além destas, sete progênies tiveram desempenhos relativos inferiores a $-30 \%$ em Anhembi: n. ${ }^{\circ} 11$ (-100,0\%), 17 ($43,0 \%), 18(-39,4 \%), 5(-36,5 \%), 33(-35,8 \%), 8(-34,0 \%)$ e $27(-31,0 \%)$; e outras quatro progênies na ESALQ: n. ${ }^{\circ} 2$ (-56,1\%), 20 (-39,6\%), 23 (-34,9\%) e $22(-34,4 \%)$. Apenas cinco progênies atingiram valores relativos positivos para \%V1, tês em Anhembi: n. 7 (237,5\%), 29 (22,9\%) e 21 (5,6\%); e outras duas na ESALQ: n. ${ }^{\circ}$ $(28,4 \%)$ e $19(1,2 \%)$. 
A Tabela 15 também indica que a porcentagem de vagens com duas sementes (\%V2) variou nas progênies de 39,97\% a 79,30\% (média de 63,0\%; próximo da média das testemunhas, $64,5 \%)$. Um total de 14 progênies (42,4\%) mostraram valores maiores de \%V2. Foram encontradas seis progênies superiores a melhor testemunha, Céu Azul (69,3\%V2/planta): n. 13 (79,3\%V2/planta), 15 (72,9\%V2/planta), 16 (72,7\%V2/planta), 24 (72,1\%V2/planta), 20 (71,4\%V2/planta) e 2 (70,5\%V2/planta). Duas progênies tiveram \%V2 inferiores a 50\%V2/planta: n. $^{\circ} 11(43,0 \% \mathrm{~V} 2 /$ planta) e 14 (39,9\%V2/planta). Destaca-se o fato de que duas progênies originárias do cruzamento Late Giant x Doko, mostraram os maiores valores de \%V2 ( . $^{\circ} 13$ e 15$)$ enquanto que outras duas apresentaram os menores valores para este mesmo caráter ( $n^{\circ} 14$ e 11), indicando que há uma grande diversidade dentro deste cruzamento.

Comparando-se o desempenho em cada local, em relação à média das testemunhas (Tabela 16), verifica-se que 30 das 66 progênies $(45,4 \%)$ apresentaram valores menores. Na maioria dos casos, os valores de \%V2 das progênies foram maiores em Anhembi (51,5\%) em relação a ESALQ (48,5\%). Das 33 progênies, apenas duas tiveram desempenhos relativos inferiores a $-20 \%$ nos dois locais, respectivamente, Anhembi e ESALQ: n. 11 (-42,9\% e -24,5\%) e 14 (-36,5\% e -39,8\%). Além destas, três progênies tiveram desempenhos relativos inferiores a -20\% em Anhembi: n. ${ }^{\circ} 7(-64,1 \%)$, 18 (-15,7\%) e 21 (-10,8\%); e quatro progênies na ESALQ: n. ${ }^{\circ} 19(-17,0 \%), 23(-14,2 \%)$, $27(-11,7 \%)$ e $4(-10,8 \%)$. Apenas três progênies atingiram valores relativos superiores a $10 \%$ nos dois locais, respectivamente, Anhembi e ESALQ: . $^{\circ} 13$ (23,2\% e 22,6\%), 15 $(12,6 \%$ e $13,2 \%)$ e $16(12,3 \%$ e 12,8\%). Duas progênies tiveram desempenhos relativos superiores a 10,0\% em Anhembi: n. 24 (19,9\%) e 20 (14,3\%).

Vagens com três ou mais sementes são as preferidas para consumo na forma de edamame; então, devem ser selecionadas progênies que tenham maiores porcentagens destes tipos de vagens. A Tabela 15 indica que para as progênies a porcentagem de vagens com três ou mais sementes por planta $(\% \mathrm{~V} 3)$ variou de $7,2 \% \mathrm{~V} 3 /$ planta a $50,4 \% \mathrm{~V} 3 /$ planta (média de $19,0 \% \mathrm{~V} 3 /$ planta); tais valores são altos se comparados com a média das testemunhas $(12,3 \% \mathrm{~V} 3 /$ planta). Apenas seis progênies $(18,2 \%)$ mostraram valores menores de \%V3 que a média das testemunhas: n. $^{\circ} 7(7,2 \% \mathrm{~V} 3 /$ planta), 24 
(7,9\%V3/planta), 13 (8,5\%V3/planta), 31 (11,4\%V3/planta), 20 (11,5\%V3/planta) e 29 (11,5\%V3/planta). A média geral das testemunhas foi reduzida pelo cultivar Tamba, que mostrou média muito inferior às demais $(4,5 \% \mathrm{~V} 3 /$ planta). Considerando apenas a melhor testemunha, Céu Azul (15,6\%), ainda se tem 25 progênies com \%V3 superiores; destas, duas se destacam, com \%V3 relativos superiores a 40,0\%: n. $^{\circ} 11$ $(45,7 \% \mathrm{~V} 3 /$ planta $)$ e $14(50,4 \% \mathrm{~V} 3 /$ planta), ambas originárias do cruzamento Late Giant $\mathrm{x}$ Doko.

Comparando-se o desempenho em cada local (Tabela 16), observa-se uma grande amplitude de respostas em relação à média das testemunhas, com variação de $100,0 \%$ a $298,9 \%$. Verifica-se que dez das 66 progênies $(15,1 \%)$ apresentaram valores menores. Na maioria dos casos, a \%V3 das progênies atingiu maiores valores na ESALQ (75,8\%) em relação a Anhembi (24,2\%). Das 33 progênies, apenas duas tiveram desempenhos relativos inferiores a $\mathbf{- 2 0 \%}$ nos dois locais, respectivamente, Anhembi e ESALQ: n. $^{\circ} 24(-44,1 \%$ e $-21,7 \%)$ e $13(-12,4 \%$ e -59,14\%). Três progênies tiveram desempenhos relativos inferiores a $-20 \%$ em Anhembi: $n .^{\circ} 7(-100,0 \%), 29(-19,6 \%)$ e 20 (-15,7\%), e duas progênies na ESALQ: n. 17 (-37,9\%) e 31 (-23,4\%). Entre os melhores desempenhos, três progênies atingiram valores relativos superiores a $100 \%$ nos dois locais, respectivamente, Anhembi e ESALQ: n. ${ }^{\circ} 11$ (298,9\% e 231,8\%), 14 $(225,4 \%$ e $438,8 \%)$ e $18(127,3 \%$ e $108,6 \%)$. Apenas a progênie $n^{\circ} 18$ apresentou desempenho relativo superior a $100,0 \%$ em Anhembi (127,3\%), enquanto nove progênies tiveram na ESALQ: n. 23 (186,0\%), 4 (159,4\%), 12 (138,0\%), 10 (127,9\%), 19 (119,6\%), 33 (114,2\%), 27 (110,7\%), 25 (110,2\%) e 32 (110,1\%).

\subsection{Comparação de médias e agrupamento das progênies pelo teste de Scott-Knott}

As comparações e classificações das progênies pelo teste de Scott-Knott são apresentadas na Tabela 17 para os dois locais combinados, sendo as discussões concentradas nas progênies dos melhores grupos e, mais raramente, nas progênies dos 
piores grupos. Embora as análises e classificações tenham sido feitas com dados transformados, a discussão a seguir baseia-se em dados originais.

\subsubsection{Caracteres relacionados ao ciclo da planta}

A análise do número de dias para o florescimento (NDF) dos dois locais combinados (Tabela 17) permitiu a formação de três grupos, sendo que no grupo A, com plantas mais precoces, as médias variaram de 57,0 a 61,2 dias, sendo incluídas cinco progênies (n. ${ }^{\circ} 9,15,22,11$ e 27). O grupo B, intermediário, teve médias de 64,7 a 75,8 dias, incluindo-se 25 progênies e as quatro testemunhas. $\mathrm{O}$ grupo $\mathrm{C}$, com plantas mais tardias, teve médias de 76,7 a 78,5 dias e compreendeu três progênies (n. ${ }^{\circ} 23,25$ e 29). Comparativamente foram obtidos menos grupos em $F_{11: 4}$ do que na geração $F_{3}$, para a qual foram obtidos seis grupos, quando se considera apenas os 40 topocruzamentos com Doko (Pacova, 1992).

A análise do número de dias para a maturidade (NDM) dos dois locais em conjunto (Tabela 17) permitiu a formação de quatro grupos, sendo que no grupo $\mathrm{A}$, com plantas mais tardias, as médias variaram de 154,3 a 162,4 dias, sendo incluídas 11 progênies ( $n .^{\circ} 24,7,25,4,19,23,6,23,31,5,10$ e 29) e a testemunha Tamba. O grupo B teve médias de 143,2 a 151,5 dias, incluindo-se dez progênies e as testemunhas Céu Azul e IAC PL-1. O grupo C teve médias de 133,9 a 142,1 dias, incluindo-se sete progênies e a testemunha Nimame. $\mathrm{O}$ grupo $\mathrm{D}$, com plantas mais precoces, teve médias de 123,4 a 131,5 dias e compreendeu cinco progênies (n. ${ }^{\circ} 22,9,14,15$ e 11). Comparativamente, foram obtidos cinco grupos na geração $F_{3}$ (Pacova, 1992) para os 40 topocruzamentos com Doko; quatro grupos na geração $F_{5: 4}$ (Yokomizo, 1994), para os 40 topocruzamentos com Doko e cinco grupos na geração $\mathrm{F}_{9: 4}$ (Yokomizo, 1999), com 24 progênies originárias de 15 topocruzamentos, sendo 14 com Doko e um com FT-2.

A diversidade observada para NDF e NDM indica de início a possibilidade de obtenção de progênies com diferentes ciclos de maturação, fato este muito valorizado na agricultura modema. Além disso, a diversidade entre NDF e NDM também permite a existência de progênies com período juvenil mais longo do que os parentais exóticos tipo alimento, de maneira a se cumprir um dos objetivos iniciais do programa (Destro, 1991; 
Pacova, 1992). Certamente, genes para período juvenil mais longo presentes no parental adaptado Doko (Kiihl \& Garcia, 1989), devem ter sido transferidos para as progênies e contribuído para ampliar o período juvenil das mesmas, comparativamente aos parentais exóticos tipo alimento.

A análise do período reprodutivo (PR) dos dois locais combinados (Tabela 17) permitiu a formação de apenas dois grupos. No grupo A, formado por progênies com plantas apresentando maior diferença no número de dias entre o NDF e o NDM, as médias variaram de 74,5 a 86,28 dias, sendo incluídas 20 progênies (n. ${ }^{\circ} 20,2,16,26,25$, $30,17,1,23,10,24,6,7,19,27,5,8,31,29$ e 4) e as testemunhas Céu Azul, IAC PL-1 e Tamba. O grupo B teve médias de 59,1 a 73,7 dias, incluindo-se as 13 progênies restantes e a testemunha Nimame. Comparativamente foram obtidos menos grupos em $F_{11: 4}$ do que na geração $F_{3}$, onde se obteve quatro grupos considerando-se apenas os topocruzamentos com Doko (Pacova, 1992).

\subsubsection{Caracteres relacionado à altura da planta e ao acamamento}

A Tabela 17 indica que a análise da altura da planta no florescimento (APF) dos dois locais combinados permitiu a formação de quatro grupos. No grupo A, com plantas mais altas no florescimento, as médias variaram de 79,5 a $92,8 \mathrm{~cm}$, sendo incluídas quatro progênies (n. ${ }^{\circ} 19,24,17$ e 6). O grupo B teve médias de 65,3 cm a 73,3 $\mathrm{cm}$, incluindo 12 progênies. $\mathrm{O}$ grupo $\mathrm{C}$ teve médias de 52,2 a $61,6 \mathrm{~cm}$, incluindo 12 progênies $\mathrm{e}$ as quatro testemunhas. $\mathrm{O}$ grupo $\mathrm{D}$, com plantas mais baixas no florescimento, teve médias de 40,1 a $47,8 \mathrm{~cm}$ e compreendeu cinco progênies (n. ${ }^{\circ} 9,26$, 22, 20 e 27). Comparativamente foram obtidos menos grupos em $F_{11: 4}$ do que na geração $\mathrm{F}_{3}$, onde se obteve cinco grupos, considerando-se apenas os 40 topocruzamentos com Doko (Pacova, 1992).

A análise da altura da planta na maturidade (APM) dos dois locais combinados (Tabela 17) permitiu a formação de quatro grupos, sendo que no grupo $\mathrm{A}$, com plantas mais altas, as médias variaram de 104,7 a $112,5 \mathrm{~cm}$, sendo incluídas cinco progênies (n. ${ }^{\circ}$ 17, 6, 10, 19 e 24). O grupo B teve médias de 90,7 a 94,6 cm, incluindo-se três progênies. $\mathrm{O}$ grupo $\mathrm{C}$ teve médias de 77,7 a $86,1 \mathrm{~cm}$, incluindo-se oito progênies e a 
testemunha Tamba. $\mathrm{O}$ grupo D, com plantas mais baixas, teve médias de 44,8 $\mathrm{cm}$ a 69,0 cm e compreendeu 17 progênies ( $\mathrm{n}^{\circ} 9,26,22,20,27,2,18,15,31,33,21,28,13,8,16$, 11 e 14) e as testemunhas IAC PL-1, Céu Azul e Nimame. Comparativamente foram obtidos menos grupos em $F_{11: 4}$ do que na geração $F_{3}$, onde se obteve sete grupos, considerando-se apenas os topocruzamentos com Doko (Pacova, 1992). Os cruzamentos que deram origem a algumas das progênies mais altas em $F_{11: 4}$ como as progênies $n .^{\circ} 6$ [(KS $473 \times$ SJ2 - F $)$ x Doko], n. ${ }^{\circ} 10$ (Araçatuba x Doko) e n..$^{\circ} 24$ (Aliança Preta x Doko) já mostravam em $F_{3}$ elevada APM. Na geração $F_{5: 4}$, foram obtidos sete grupos (Yokomizo, 1992), sendo que o cruzamento que deu origem à progênie $\mathrm{n}^{\circ} 10$ (Araçatuba x Doko), também se destacou pela elevada APM. Na geração $F_{9: 4}$, foram obtidos cinco grupos (Yokomizo, 1999), destacando-se no grupo A, quatro das cinco progênies classificadas neste trabalho: $\mathrm{n}^{\circ} 6$ \{USP98-06007 - [(KS $\left.473 \times \mathrm{SJ} 2-\mathrm{F}_{2}\right) \times$ Doko]\} , n. ${ }^{\circ} 10$ [USP98-060011 - (Araçatuba x Doko)], n. 17 [USP98-06018 - (Late Giant x Doko)] e n. 24 [USP98-06025 - (Aliança Preta x Doko)].

A análise da diferença na altura da planta entre a APF e a APM (DAP) dos dois locais combinados (Tabela 17) permitiu a formação de quatro grupos. No grupo A, com plantas apresentando maior diferença de altura entre APF e APM, incluiu apenas a progênie $\mathrm{n}^{\circ} 10$, com média de $48,1 \mathrm{~cm}$. O grupo $\mathrm{B}$ teve médias de 23,1 a $28,8 \mathrm{~cm}$, incluindo-se três progênies (n. ${ }^{\circ} 29,17$ e 19). $\mathrm{O}$ grupo $\mathrm{C}$ teve médias de 16,8 a $21,1 \mathrm{~cm}$, incluindo-se sete progênies (n. ${ }^{\circ} 7,30,6,4,3,24$ e 23) e a testemunha Tamba. $O$ grupo $\mathrm{D}$, com plantas de menor DAP, teve médias de 5,6 a 14,6 cm e compreendeu as demais 22 progênies e as testemunhas IAC PL-1, Nimame e Céu Azul.

A obtenção de progênies mais altas (grupos A e B) que as testemunhas pode ser associada tanto com os genes para período juvenil longo provenientes do parental Doko, quanto com os genes para hábito de crescimento (Bermard, 1971).

A análise do acamamento (AC) dos dois locais em conjunto (Tabela 17) incluiu todas as progênies e as testemunhas em um mesmo grupo, apesar da variação de 1,14 a 2,58. Embora o teste $\mathrm{F}$ tenha mostrado a existência de diferenças significativas entre as progênies, o teste de Scott-Knott não foi suficientemente sensível para detectálas entre as médias transformadas. O coeficiente de variação de 10,8\% poder ser 
classificado como médio para o AC. Desta forma pode-se considera que a variação observada $(1,14$ a 2,58) não é de grande magnitude. Também, deve-se considerar que o sistema de cultivo empregado, na forma de plantas individuais, com competição mínima $(80 \mathrm{~cm} \times 80 \mathrm{~cm})$, favorece a ramificação, tende a diminuir a altura e o acamamento das plantas. Além disso, o tutoramento realizado no período de desenvolvimento vegetativo, também pode ter contribuído para diminuir o acamamento. Contrariamente, na geração $\mathrm{F}_{5: 4}$ foram obtidos cinco grupos; considerando-se apenas os 40 topocruzamentos com Doko (Yokomizo, 1994), dez topocruzamentos que ficaram no grupo das plantas mais eretas originaram 14 das 33 progênies avaliadas neste trabalho. Yokomizo (1999), obteve quatro grupos, sendo que no grupo das plantas mais eretas, as progênies n. 9 (USP98-06008), 14 (USP98-06015), 20 (USP98-06021) e 26 (USP98-06027) já haviam se destacado em $\mathrm{F}_{5: 4}$. Apesar de não terem sido encontradas diferenças pelo teste de Scott-Knott, as progênies $n .^{\circ} 26$ e 9 na geração $F_{11: 4}$ também foram as que tiveram menor acamamento.

\subsubsection{Valor agronômico, produtividade de grãos, vagens e de óleo}

Pela Tabela 17, a análise do valor agronômico (VA) dos dois locais combinados permitiu a formação de apenas dois grupos. No grupo $\mathrm{A}$, com plantas de melhor valor agronômico, as médias variaram de 2,83 a 3,41, sendo incluídas 19 progênies (n. ${ }^{\circ} 33,11,14,24,31,28,10,30,32,16,17,4,7,5,13,23,19,18$ e 29$)$ e as testemunhas Céu Azul e Tamba. O grupo B apresentou plantas com VA relativamente menor, com médias de 2,13 a 2,77, incluindo-se as demais 14 progênies e as testemunhas IAC PL-1 e Nimame. Comparativamente na geração $F_{3}$ foram obtidos cinco grupos (Pacova, 1992) e na geração $F_{5: 4}$ quatro grupos (Yokomizo, 1994), considerandose apenas os 40 topocruzamentos com Doko em ambos os trabalhos. Um total de 13 topocruzamentos foram incluídos no grupo de plantas com maior $V A$ em $F_{5: 4}$ (Yokomizo, 1994), incluindo 26 das 33 progênies avaliadas em $F_{11: 4}$, tendo 16 delas sido classificadas no grupo A. Yokomizo (1999) em F9:4, também obteve dois grupos; no grupo A obteve 14 progênies, sendo que delas 11 também estão no grupo A agora formado em $\mathrm{F}_{11: 4}$. 
A análise da produtividade de grãos (PG) dos dois locais combinados (Tabela 17) permitiu a formação de apenas dois grupos. No grupo A, com plantas mais produtivas, as médias variaram de 121,4 a 177,9 g/planta, sendo incluídas 19 progênies (n. ${ }^{\circ} 33,6,20,7,11,31,3,28,5,14,19,2,25,23,16,24,12,17$ e 13 ) e as testemunhas Céu Azul e IAC PL-1. O grupo B com médias de 67,7 a $116 \mathrm{~g} /$ planta, incluiu as demais 14 progênies e as testemunhas Nimame e Tamba. Comparativamente foram obtidos menos grupos em $F_{11: 4}$ do que na geração $F_{3}$, onde se obteve quatro grupos considerando-se apenas os cruzamentos com Doko (Pacova, 1992). Yokomizo (1994) obteve cinco grupos em $\mathrm{F}_{5: 4}$, sendo que alguns cruzamentos incluídos no grupo A também se destacaram em $F_{9: 4}$, mas não em $F_{11: 4}$. Yokomizo (1999) obteve quatro grupos em $\mathrm{F}_{9: 4}$, sendo que cinco progênies foram incluídas no grupo A; quatro delas também foram classificadas no grupo $\mathrm{A}$ deste trabalho, com destaque para progênies originárias do cruzamento Late Giant x Doko [n. 13 (USP98-06014), n. ${ }^{\circ} 16$ (USP9806017) e n..$^{\circ} 17$ (USP98-06018)].

A análise da porcentagem de óleo nas sementes $(\% \mathrm{OL})$ dos dois locais combinados (Tabela 17) permitiu a formação de três grupos. $\mathrm{O}$ grupo $\mathrm{A}$, apresentou plantas apresentando com maior \%OL, as médias variaram de $19,1 \% \mathrm{OL}$ a $21,2 \% \mathrm{OL}$, sendo incluídas 18 progênies ( . $^{\circ} 10,24,20,30,32,16,11,8,33,21,12,13$,18, 14, 2, 17, 9 e 22) e as testemunhas Nimame, Céu Azul e IAC PL-1. O grupo B teve médias de $18,2 \% \mathrm{OL}$ a 18,9 \%OL, incluindo-se dez progênies. $\mathrm{O}$ grupo $\mathrm{C}$ teve médias de 16,5 $\% \mathrm{OL}$ a 17,4 \%OL, incluindo-se cinco progênies (n. ${ }^{\circ} 4,1,29,27$ e 7) e a testemunha Tamba. Deve-se lembrar que para o consumo direto como alimento são desejáveis cultivares de soja com o menor teor de óleo possível nas sementes, com a finalidade de obter produtos com sabor e odor melhores (Taira, 1990; Vello, 1992b; Bernard, 1999).

À semelhança do observado com PG, a análise da produtividade de óleo por planta (PO) dos dois locais em conjunto (Tabela 17) permitiu também a formação de apenas dois grupos. No grupo A, com plantas produtoras de mais de óleo, as médias variaram de 31,8 a 36,6 g óleo/planta, sendo incluídas cinco progênies ( $\mathrm{n}^{\circ}$ 24, 16, 12,17 e 13). O grupo B teve médias de 10,6 a 29,1 g óleo/planta, incluindo-se as demais 28 progênies e as quatro testemunhas. As progênies com menor quantidade de óleo nas 
sementes são mais apropriadas ao uso como soja tipo alimento. Já as progênies produtoras de sementes mais ricas em óleo, podem ser analisadas quanto à composição, para verificar possível uso na produção de alimentos à base de soja industrializados (tofu, misso, extrato de soja, etc.); podem, também, originar genótipos tipo grão para cultivo visando-se uso na indústria de óleo e farelo e, também, podem participar como parentais em programas para ampliação da base genética e melhoramento da soja cultivada.

A análise do número total de vagens (NTV) dos dois locais combinados (Tabela 17) permitiu a formação de apenas dois grupos. No grupo A, formado pelas progênies com maior número de vagens por planta, as médias variaram de 365,0 a 572,5

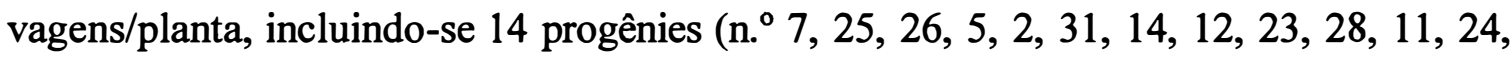
17 e 13) e as testemunhas Nimame e Tamba. O grupo $B$ teve médias de 179,2 a 349,8 vagens por planta, incluindo-se as demais 19 progênies e as testemunhas Céu Azul e IAC PL-1.

A Tabela 17 mostra que a análise do peso de vagens por planta (PV) dos locais combinados permitiu a formação de apenas dois grupos. No grupo A, com plantas mais produtivas em vagens, as médias variaram de 224,7 $\mathrm{g}$ de vagens/planta a $301,1 \mathrm{~g}$ de vagens/planta, sendo incluídas dez progênies (n. ${ }^{\circ} 19,2,25,23,5,16,12,24,13$ e 17) e as testemunhas Céu Azul e IAC PL-1. O grupo B teve médias de 113,0 g de vagens/planta a 214,0 $\mathrm{g}$ de vagens/planta, e incluiu as demais 23 progênies e as testemunhas Nimame e Tamba, cultivares de soja tipo alimento desenvolvidas no Brasil.

\subsubsection{Caracteres relacionados ao tamanho das sementes e tipos de vagens}

A análise da largura visual de vagens (LVV) dos dois locais combinados (Tabela 17) permitiu a formação de três grupos. No grupo A, formado por progênies produtoras de vagens mais largas, as médias variaram de 2,82 a 3,41, sendo incluídas 17 progênies ( $\mathrm{n}^{\circ} 23,27,15,9,13,4,5,12,18,22,10,16,21,20,30,3$ e 19) e as testemunhas Céu Azul, IAC PL-1 e Tamba. O grupo B teve médias de 2,31 a 2,75, incluindo 12 progênies e a testemunha Nimame. $\mathrm{O}$ grupo $\mathrm{C}$, contendo plantas produtoras 
de vagens mais estreitas, teve médias de 1,62 a 2,23, incluindo apenas quatro progênies (n. ${ }^{\circ}$ 14, 26, 28 e 8). Comparativamente foram obtidos menos grupos em $F_{11: 4}$ do que na geração $\mathrm{F}_{3}$, onde se obteve seis grupos, considerando-se apenas os topocruzamentos com Doko (Pacova, 1992). Já Yokomizo (1994) obteve seis grupos em $F_{5: 4}$, com destaque para o cruzamento Japão 1 x Doko, que originou as progênies n. ${ }^{\circ} 19$ (USP98-06020) e n. 18 (USP98-06019), sendo que a primeira apresentando a maior nota de LVV entre as 33 progênies avaliadas em $F_{\text {11:4 }}$. Yokomizo (1999), obteve quatro grupos em $F_{9: 4}$, sendo que cinco progênies foram incluídas no grupo A; duas delas também se classificaram no grupo $A$ na geração $F_{11: 4}$, novamente com destaque para a progênie $n^{\circ} 18$ (USP9806019). A progênie n. 19 (USP98-06020) não foi utilizada em $F_{9: 4}$ por Yokomizo (1999), por falta de sementes; já a progênie USP98-06006 foi descartada devido à baixa germinação das sementes.

A análise do peso de cem sementes (PCS) dos dois locais combinados (Tabela 17) permitiu a formação de quatro grupos. No grupo A, com plantas produtoras de sementes maiores, as médias variaram de 23,5 a 25,6 g/100 sementes, sendo incluídas 13 progênies (n. ${ }^{\circ} 10,9,22,5,15,20,18,12,3,21,30,16$ e 19) e a testemunha IAC PL1 e Tamba. O grupo B teve médias de 20,9 a 23,1 g/100 sementes, incluindo-se 13 progênies e a testemunha Céu Azul. $O$ grupo $C$ teve médias de 18,6 a 20,6 g/100 sementes, incluindo-se cinco progênies. $\mathrm{O}$ grupo $\mathrm{D}$, com plantas produtoras de sementes menores, teve médias de 15,2 a 17,1 g/100 sementes, compreendeu apenas duas progênies (n. ${ }^{\circ} 14$ e 26) e a testemunha Nimame. Considerando-se apenas os topocruzamentos com Doko, obteve-se o mesmo número de quatro grupos em $\mathrm{F}_{11: 4}$, na geração $F_{3}\left(\right.$ Pacova, 1992) e na geração $F_{9: 4}$ (Yokomizo, 1999); todavia, na geração $F_{5: 4}$, foram obtidos três grupos (Yokomizo, 1994). Na geração $F_{9: 4}$ (com quatro progênies nos grupo A) e em $F_{11: 4}$ (com 13 progênies no grupo $A$ ), os destaques foram dois cruzamentos: Japão x Doko, que originou a progênie n. ${ }^{\circ} 19$ (USP98-06020), e Late Giant $x$ Doko, que originou a progênie . $^{\circ} 16$ (USP98-06017), com os valores mais altos de PCS.

A análise da porcentagem de vagens com uma semente (\%V1) dos dois locais em conjunto (Tabela 17) permitiu a formação de dois grupos. No grupo A, 
contendo plantas com maior $\% \mathrm{~V} 1$, as médias variaram de $18,1 \%$ a $36,5 \%$, incluindo-se 12 progênies $\left(\mathrm{n}^{\circ} 3,27,1,12,6,31,10,21,19,9,29\right.$ e 7$)$ e as testemunhas Tamba e Nimame. O grupo B teve médias de 9,7\% a 17,1\%, incluindo-se as demais 21 progênies e as testemunhas Céu Azul e IAC PL-1.

A análise da porcentagem de vagens com duas sementes (\%V2) dos dois locais combinados permitiu a formação de três grupos. No grupo A, com plantas apresentando maior \%V2, as médias variaram de 65,7\% a 79,3\%, incluindo-se 12 progênies (n. ${ }^{\circ} 30,3,26,31,28,17,2,20,24,16,15$ e 13) e as testemunhas Céu Azul, IAC PL-1 e Nimame. O grupo B teve médias de 55,8\% a 64,8\%, incluindo-se 19 progênies e a testemunha Tamba. $\mathrm{O}$ grupo $\mathrm{C}$, com plantas com menor \%V2, teve médias de 39,9\% a 43,0\%, incluindo-se apenas duas progênies (n. ${ }^{\circ} 14$ e 11 ).

A análise da porcentagem de vagens com três ou mais sementes por planta (\%V3) dos dois locais em conjunto (Tabela 17) permitiu a formação de três grupos. No grupo A, com plantas com maior $\% \mathrm{~V} 3$, as médias variaram de $45,7 \%$ a $50,4 \%$, incluindo-se apenas duas progênies ( $\mathrm{n}^{\circ} 14$ e 11 ). O grupo $\mathrm{B}$ teve médias de $18,4 \%$ a $27,1 \%$, incluindo-se 15 progênies. $\mathrm{O}$ grupo $\mathrm{C}$, apresentando plantas com menor \%V3, teve médias de 7,3\% a 17,7\%, incluindo-se 16 progênies ( $\mathrm{n}^{\circ} 7,24,13,31,20,29,16$, $17,15,3,2,6,21,1,9$ e 28$)$ e as quatro testemunhas. Portanto, mais de $50 \%$ das progênies foram classificadas nos grupos $\mathrm{A}$ e $\mathrm{B}$, apresentando maiores \%V3 do que as quatro testemunhas tipo alimento (grupo $\mathrm{C}$ ), fato este altamente promissor para $\mathrm{o}$ desenvolvimento de novos cultivares de soja tipo alimento com sementes grandes.

\subsection{Correlações fenotípicas}

Embora tenha sido possível acrescentar níveis de significância estatística às estimativas de correlações fenotípicas (Tabelas 18 e 19), existe uma tendência entre os melhoristas de plantas de se valorizar mais o sinal; (positivo ou negativo) e a magnitude dos valores, na interpretação aplicada das correlações. Neste sentido, um critério comum é valorizar as estimativas abaixo de $-50 \%$ e acima de $50 \%$.

Este critério baseia-se nas causas genéticas das correlações entre caracteres: a) ligação genética entre os genes que controlam dois caracteres, difícil de ser superado 
(quebrado) quando muito forte (c $\leq 10 \%$ de recombinação), podendo, neste caso, até impedir o aparecimento de recombinantes desejáveis nas gerações filiais de cruzamento; b) pleiotropia, ou seja, o(s) mesmo(s) gene(s) controlam os dois caracteres; neste caso, a possibilidade de obtenção de recombinantes fica restrita à ocorrência de mutações espontâneas e ou induzidas. Quando se trata de ligação, os valores da correlação podem variar de $-100 \%$ a $100 \%$, dependendo da distância genética entre os genes. Já no caso de pleiotropia, a correlação é muito alta, próxima de $-100 \%$ ou de $100 \%$. Portanto, correlações no intervalo de $-50 \%<\mathrm{r}<50 \%$ e $50 \%<\mathrm{r}<100 \%$ são difíceis de serem suplantadas, levando à classificação em caracteres associados negativa e positivamente, respectivamente.

As estimativas de correlações fenotípicas de Pearson para as testemunhas e para as progênies são apresentadas nas Tabelas 18 e 19, respectivamente. Foram considerados dez dos 18 caracteres, sendo um relacionado à planta $(P R)$ e nove caracteres relacionados à semente ou à vagem $(\mathrm{LVV}, \mathrm{PG}, \mathrm{PCS}, \% \mathrm{OL}, \mathrm{NTV}, \% \mathrm{~V} 1$, \%V2, \%V3 e PV). Para esta análise não foram utilizados todos os caracteres, pois correlações entre os caracteres como NDF, APF, NDM, APM, AC e VA tem sido muito pesquisadas, inclusive em gerações anteriores deste mesmo programa por Destro (1991), Pacova (1992), Yokomizo (1994) e Yokomizo (1999). O caráter PO não foi incluído, por ser altamente dependente dos caracteres PG e \%OL (Zimback, 1993; Soldini, 1993; Montaño-Velasco, 1994; Farias Neto, 1995; Laínez-Mejía, 1996; Rocha, 1998; Hamawaki, 1998).

Observa-se que há variações na magnitude das correlações analisadas, entre locais e entre os dois grupos de genótipos (testemunhas e progênies). Este fato concorda com as informações disponíveis na literatura (Yokomizo, 1994; Yokomizo, 1999).

Em geral as correlações mostraram tendências semelhantes quando estimadas ao nível de médias de locais individuais e combinados, nas ocorreram exceções à tendência geral, principalmente na significância das estimativas das correlações.

Nas Tabelas 18 e 19, verifica-se que, para os dois grupos de genótipos, o local Anhembi apresentou maiores magnitudes de estimativas de correlações, 
relativamente ao local ESALQ. Para o grupo das testemunhas, Anhembi apresentou maiores correlações fenotípicas em 23 das 45 combinações dos dez caracteres dois a dois. Para o grupo das progênies, Anhembi mostrou maiores correlações em 29 das 45 combinações.

Observa-se nas Tabelas 18 e 19 um efeito muito pequeno, praticamente desprezível, dos locais sobre as magnitudes das correlações fenotípicas. Entre as testemunhas (Tabela 18) os maiores efeitos de locais ocorreram nas correlações: LVV $\operatorname{NTV}\left(r_{f}=-36,55\right.$ em Anhembi e $r_{f}=22,91$ na ESALQ), PG - NTV $\left(r_{f}=-10,54\right.$ em Anhembi e $r_{f}=45,32$ na ESALQ), PG - \%V3 $\left(r_{f}=46,14\right.$ em Anhembi e $r_{f}=-15,68$ na ESALQ. Entre as progênies (Tabela 19), a concordância entre os locais em termos de correlações fenotípicas foi ainda maior daquela observada entre as testemunhas, não havendo efeito pronunciado de locais em nenhuma das 45 estimativas de correlações.

Contrariamente, existe um efeito relativo pronunciado dos genótipos sobre a magnitude das correlações, pois pelo menos 15 (33\%) das testemunhas exibiram diferenças grandes entre as testemunhas (Tabela 18) e as progênies (Tabela 19), respectivamente, para os dois locais combinados, em porcentagem: PR - LVV $(82,24 * *$ vs. 14,33$), \mathrm{PR}-\mathrm{PCS}\left(81,96^{* *}\right.$ vs. 7,24$), \mathrm{PR}-\% \mathrm{~V} 1$ (70,77** vs. 20,25$), \mathrm{PR}-\% \mathrm{~V} 2$ ($53,89^{* *}$ vs. $\left.18,63^{*}\right), \mathrm{PR}-\% \mathrm{~V} 3\left(-60,34^{* *}\right.$ vs. $\left.-35,87^{* *}\right)$, LVV- \%OL $\left(-46,88^{* *}\right.$ vs. 6,61), LVV - \%V2 (-43,87* vs. 21,36), PG - NTV (39,32* vs. 74,90**), PCS - \%OL ($48,67^{* *}$ vs. 7,99$), \operatorname{PCS}-\% \mathrm{~V} 1$ (45,36* vs. 10,63$)$, PCS - \%V2 (-47,11** vs. $\left.21,60^{*}\right)$, \%OL - \%V1 (-73,49** vs. $-11,16), \% \mathrm{OL}-\% \mathrm{~V} 2$ (71,30** vs. $-0,49), \% \mathrm{OL}-\% \mathrm{~V} 3$ $\left(51,68^{* *}\right.$ vs. 11,41$), \% \mathrm{~V} 2-\% \mathrm{~V} 3\left(20,70\right.$ vs. $\left.-70,61^{* *}\right)$. Este fato aponta a necessidade de se considerar individualmente os genótipos na interpretação das correlações fenotípicas, pelo menos para as 15 combinações de correlações contrastantes antes reportadas.

Algumas correlações fenotípicas podem fornecer interpretações aplicadas muito interessantes para os dois grupos de genótipos. 


\subsubsection{Caracteres não-associados}

Compreende as combinações de caracteres com correlações no intervalo $50 \%<\mathrm{r}<50 \%$, incluindo 29 das 45 recombinações, a saber: PR x PG, PR x NTV, PR x PV, LVV x PG, LVV x \%OL, LVV x NTV, LVV x \%V1, LVV x \%V2, LVV x \%V3, LVV x PV, PG x PCS, PG x \%OL, PG x \%V1, PG x \%V2, PG x \%V3, PCS x \%OL, PCS $x$ NTV, PCS $x \%$ V 1 , PCS $x \%$ V2, PCS $x \%$ V3, PCS $x$ PV, \%OL $x$ NTV, \%OL $x$ PV, NTV x \%V1, NTV x \%V2, NTV x \%V3, \%V1 x PV, \%V2 x PV e \%V3 x PV.

A correlação entre PR e PG mostrou-se correlação negativa e de pequena magnitude, mas significativa para as progênies (-19,39\%), mas não se mostrou significativa para as testemunhas $(0,06 \%)$. Contrariamente, Pacova (1992) obteve correlação entre PR e PG positiva e com alta magnitude (65,0\%).

As correlações entre LVV e PG foram positivas, mas não significativas em nenhum dos grupos de genótipos para os locais combinados, mas foram significativas para testemunhas em Anhembi (53,7\%). Santos (1988) obteve correlação significativa entre estes caracteres da ordem de 28,0\%. Yokomizo (1994) encontrou baixas correlações entre estes caracteres, enquanto que Pacova (1992) estimou correlações negativas e significativas da ordem de $-43,0 \%$. Resultados contrastantes foram encontrados em outros trabalhos. Yokomizo (1999) obteve correlações positivas e significativas da ordem de $44,61 \%$ para progênies e de 28,85 para testemunhas.

Para LVV e \%OL, foram observadas correlações foram altamente contrastantes; enquanto o grupo das testemunhas mostrou correlação negativa e significativa $(-46,88 \%$ para os locais combinados, o grupo das progênies mostrou correlação positiva de baixa magnitude e não-significativa $(6,61 \%$ para locais combinados). Santos (1988), trabalhando com 39 genótipos de soja com sementes grandes, obteve correlações negativas e de baixa magnitude entre estes caracteres ($15,0 \%)$.

Para LVV e NTV, a correlação fenotípica apresentou valores negativos e significativos para progênies (-22,10\% para locais combinados), mas apresentou valores negativos e não-significativos para testemunhas ( $-6,94 \%$ para locais combinados). Para 
testemunhas, a média dos dois locais não alcançou valores negativos maiores, devido ao local ESALQ que apresentou correlação positiva. Correlações negativas de elevada magnitude foram verificadas entre LVV e NTV por Johnson et al. (1955) e Kaw \& Menon (1972). Santos (1988) obteve correlação de -29,0\% significativa ao nível de 5\%. entre estes caracteres.

Correlações fenotípicas entre LVV e \%V1 foram positivas para ambos os grupos de genótipos, mas foram significativas apenas para as testemunhas, média de $47,71 \%$ nos dois locais. Para LVV e \%V2, os resultados foram contrastantes, enquanto para o grupo das testemunhas as correlações foram negativas e significativas, média de 43,73 nos dois locais, para as progênies as correlações foram positivas e significativas, média de $21,36 \%$ nos dois locais. Já para LVV e \%V3, as correlações foram negativas para os dois grupos de genótipos, mas significativas apenas para as progênies, média de $-31,06 \%$ nos dois locais, apesar do local ESALQ Ter apresentado correlação negativa altamente significativa para o grupo de testemunhas, média de $-64,75 \%$. Os resultados indicam uma tendência de quanto maior a LVV, maior o número de vagens com uma semente e menor o número de vagens com três ou mais sementes. Estes resultados foram altamente influenciados pelo comportamento contrastante do cultivar Tamba que apresentou valores médios muito altos para PCS (27,1 g/100 sementes) e para \%V1 $(40,5 \%)$ e muito baixos para \%V3 (4,5\%) (Tabela 14) em relação às outras testemunhas.

As correlações entre PG e PCS mostraram valores positivos, mas não significativos, tanto para o grupo de testemunhas como para o de progênies. Apesar de não-significativa, a correlação encontrada para o grupo das testemunhas foi maior, pois os cultivares utilizados já foram selecionados para maiores médias de PG e PCS, principalmente o cultivar Tamba. Santos (1988), trabalhando com 39 genótipos de sementes grandes, encontrou correlações positivas e de elevada magnitude $(77,1 \%)$. Pacova (1992) encontrou correlações positivas e altamente significativas em topocruzamento para sementes pequenas $(92,0 \%)$, correlações negativas e não significativas entre estes caracteres quando trabalhou com topocruzamento para sementes grandes $(-17,0 \%)$, mas estimou correlações negativas altamente significativas para os parentais utilizados para os topocruzamentos $(-47,0 \%)$. Yokomizo (1994) e Saka 
et al. (1996), trabalhando com progênies de sementes grandes, também obtiveram valores negativas para esta correlação. Estes resultados diferem dos resultados obtidos por Weber \& Moorthy (1952), Johnson et al. (1955), Kaw \& Menon (1972), Santos (1988), Santos et al. (1995) e Yokomizo (1999) que observaram correlações positivas entre o tamanho de sementes e produtividade.

As correlações entre PG e \%OL mostraram valores positivos e significativos para o grupo das testemunhas, media de 37,60\%, e o das progênies (média de 43,04\% nos dois locais). Shorter et al. (1976), Santos (1988), Zimback (1992), Soldini (1993), Montaño-Velasco (1994), Farias Neto (1995) e Laínez-Mejía (1996) obtiveram correlações positivas para estes caracteres, porém de pequena magnitude; todavia, Weber \& Moorthy (1952) e Simpson \& Wilcox (1983) encontraram variações nas estimativas, desde negativas até positivas. Barni et al. (1982) não encontraram efeito do tamanho das sementes sobre a produtividade de soja. Fontes et al. (1980) encontraram apenas correlações fenotípicas negativas.

Para PCS e \%OL, os resultados foram muito contrastantes; enquanto o grupo das testemunhas mostrou correlações negativas e altamente significativas, média de $48,67 \%$ nos dois locais, o das progênies mostrou uma baixa correlação positiva, mas não significativa, média 7,99\% nos dois locais. Tinius et al. (1993) obteve correlações fenotípicas entre tamanho de sementes (PCS) e teor de óleo (\%OL), entre 87,0\% a 97,0\%. Marega Filho (1999), trabalhando com topocruzamentos de soja tipo alimento, obteve correlação fenotípica positiva e significativa entre PCS e \%OL (69,0\%). No entanto, Santos (1988), trabalhando com sementes grandes, também obteve correlações negativas de baixa magnitude $(-28,0 \%)$. Miranda (1994) obteve estimativas negativas para esta correlação $(-24,0 \%$ e $-29,0 \%)$.

A correlação entre PCS e NTV, foi negativa e de pequena magnitude, porém, altamente significativo para o grupo das progênies (-22,8\%). Este valor está pouco acima ao obtido por Santos (1988) para esta correlação, média geral de $-16,0 \%$. A relação inversa entre tamanho de sementes (PCS) e número de vagens (NTV) está de acordo com trabalho de Egli et al. (1978), que afirma que cultivares de sementes 
pequenas necessitam de mais sementes para alcançar o máximo de acúmulo de peso comparativamente com os cultivares de sementes grandes.

A correlação entre PCS e PV mostrou valores de pequena magnitude e não significativos. Para esta correlação os valores encontrados para o grupo das testemunhas sempre foram superiores aos valores encontrados para o grupo das progênies. Santos (1988) encontrou correlações positivas entre PCS e PV da ordem de 60,0\%, altamente significativo, valor bem superior ao encontrado neste trabalho, $24,44 \%$ para as testemunhas e $12,54 \%$ para as progênies.

As correlações entre PV e os caracteres LVV, PR e PCS, mostraram valores de pequena magnitude e não significativos. Para estas três correlações, os valores encontrados para o grupo das testemunhas sempre foram superiores aos valores encontrados para o grupo das progênies. Santos (1988) encontrou correlações positivas entre PCS e PV da ordem de 60,0\%, altamente significativo, valor bem superior aos encontrados neste trabalho, $24,44 \%$ para as testemunhas e $12,54 \%$ para as progênies.

$\mathrm{Na}$ correlação entre \%OL e NTV, foram obtidos valores de magnitudes semelhantes, $24,13 \%$ para o grupo das testemunhas e $23,74 \%$ para o grupo das progênies, porém, foram significativas apenas para o primeiro grupo. No entanto, Santos (1988), encontrou correlações negativas e não-significativas da ordem de $-29,0 \%$.

\subsubsection{Caracteres associados negativamente}

Reúne as combinações com correlações negativas e altas ( $\mathrm{r} \leq-50 \%)$ incluindo sete combinações de caracteres: PR x \%OL, PR x \%V2, PR x \%V3, \%OL x $\% \mathrm{~V} 1, \% \mathrm{~V} 1$ x \%V2, \%V1 x \%V3 e \%V2 x \%V3.

As correlações entre PR e \%OL foram altamente negativas e significativas, tanto para o grupo das testemunhas (-67,70\%) como para o grupo das progênies ($50,89 \%$ ). Weber \& Moothy (1952) estudando três populações de soja, constataram correlações negativas entre estes caracteres em uma delas. Entretanto, resultados contrastantes envolvendo estes caracteres são encontrados na literatura. Wilcox (1985) encontrou correlações positivas, enquanto Zimback (1992) e Montaño-Velasco (1994) 
encontraram correlações fenotípicas negativas de pequena magnitude entre estes caracteres.

Entre PR e \%V1, as correlações encontradas foram positivas e significativas para ambos os grupos, apesar de, as testemunhas apresentaram significância a 5\%, média de $20,25 \%$ nos dois locais, enquanto as progênies apresentaram elevada magnitude e significância a $1 \%$, média de $70,77 \%$ nos dois locais. PR e \%V2 mostraram respostas diferentes; enquanto o grupo das testemunhas mostrou correlação negativa e altamente significativa $(-53,89 \%)$, o grupo das progênies mostrou correlação positiva e significativa (18,63\%). $O$ período reprodutivo mais longo das testemunhas aumenta a proporção de vagens com uma semente, possivelmente, devido a menor disponibilidade de água e nutrientes no final do ciclo.

\subsubsection{Caracteres associados positivamente}

Envolve as recombinações de caracteres com correlações positivas e altas (r $\geq 50 \%$ ), incluindo nove das 45 recombinações, a saber PR x LVV, PR x PCS, PR x \%V1, LVV x PCS, PG x NTV, PG x PV, \%OL x \%V2, \%OL x \%V3 e NTV x PV.

Nas correlações entre $P R$ e LVV os resultados foram altamente contrastantes; enquanto o grupo das testemunhas (Tabela 18) não mostrou significância (média de 14,33\% nos dois locais), o grupo das progênies (Tabela 19) mostrou correlação positiva de elevada magnitude e significância (média de $82,34 \%$ nos dois locais). Entre PR e PCS, as progênies não mostraram significância (média de 7,64\%), mas as testemunhas apresentaram correlação positiva de elevada magnitude e significância (média de $81,96 \%$ nos dois locais). Períodos reprodutivos nas testemunhas, mais ou menos seis dias a mais que nas progênies (Tabela 14), devem ter permitido uma maior granação podendo Ter elevado o tamanho das sementes e por conseqüência das vagens; por outro lado, problemas como, por exemplo, debulha das vagens que amadureceram primeiramente podem ter reduzido a produtividade na colheita. Pacova (1992) obteve para as correlações entre PR e os caracteres LVV e PCS, respectivamente, $36 ; 0 \%:$, sendo que apenas estên última é não-significativa. 
As correlações entre PG e PV foram positivas e de elevada magnitude tanto para o grupo das testemunhas, média de 74,98\%, como para o das progênies, média de $79,18 \%$. Santos (1988) obteve correlação de $97,0 \%$, altamente significativa, para estes mesmos caracteres. Portanto, tem sido alta a correlação entre o peso das vagens com sementes e o peso das sementes após a debulha das vagens. Apesar desta alta correlação, há enormes dificuldades na utilização da PV, pois este necessita que as vagens sejam separadas da planta manualmente, enquanto que para a PG a debulha é feita mecanicamente sem dificuldades.

Entre LVV e PCS, as correlações foram positivas, de elevadas magnitudes e altamente significativas, tanto para o grupo das testemunhas (média de $95,22 \%$ nos dois locais), quanto para as progênies (média de $89,23 \%$ para os dois locais). Como a largura visual de vagens (LVV) está associada diretamente com o peso de cem sementes (PCS), correlações positivas são esperadas, concordando com Frank \& Fehr (1981), Fraser et al. (1982), Shanmugasundaram \& Chung-Ruey (1982), Santos (1988), Pacova (1992), Yokomizo (1994), Yokomizo \& Vello (1998) e Yokomizo (1999). A forte associação entre estes caracteres possibilita a utilização do caráter largura das vagens para prever com segurança o peso de cem sementes (Yokomizo \& Vello, 1998). Este fato facilita muito as avaliações dos genótipos, pois a largura das vagens pode ser avaliada visualmente, evitando-se o trabalho de contagem e pesagem de sementes. Bravo et al. (1980) determinaram que quatro vagens por planta e cinco plantas por parcela, são suficientes para se obter estimativas confiáveis da média da largura das vagens de um determinado genótipo.

As correlações entre PG e NTV foram positivas para os dois grupos, sendo que para as testemunhas (média de 39,32\% nos dois locais) a significância foi a 5\%, e para as progênies (média de $74,90 \%$ nos dois locais) a significância foi a $1 \%$. Isto indica que, para as progênies, a maior produtividade de grãos foi reflexo de um maior produtividade de vagens. Este fato está de acordo com resultados obtidos por Simpson \& Wilcox (1983) em progênies $F_{6}$ e $F_{7}$, que detectaram correlações fenotípicas de elevada magnitude entre produtividade e os números de vagens e de sementes por planta. Para soja tipo alimento, Santos (1988) também obteve correlações significativas e de elevada 
magnitude para estes caracteres (74,0\%). Para soja tipo grão, Gilioli et al. (1979), Rosolém et al. (1983) e Nakagawa et al. (1988) constataram que o componente da produção que mais afetou o rendimento de grãos é o número de vagens por planta.

Finalmente, Santos (1988) encontrou correlação significativa e de elevada magnitude para a correlação entre NTV e PV, média de 73,0\%, valor muito próximo ao agora obtido para o grupo das progênies.

\subsection{Correlações genotípicas}

Para Johnson et al. (1955b) o coeficiente de correlação genotípica fornece uma medida das associações genotípicas entre caracteres e dá uma indicação das características que podem ser consideradas mais importante. $O$ ideal é que a correlação genotípica seja superior à fenotípica. Desta forma, o fenótipo será um indicativo seguro do genótipo, o que proporciona ganhos genéticos indiretos (resposta correlacionada à seleção) com segurança.

$\mathrm{Na}$ Tabela 20 são apresentadas as estimativas das correlações genotípicas para o grupo das progênies, considerando-se os dois locais combinados. Observa-se que 19 entre as 45 correlações apresentaram resultados fora do intervalo esperado ( -100 a +100). Resultados semelhantes, ou seja, fora do intervalo esperado também foram relatados por Destro (1983), Yokomizo (1999) e por Marega Filho (1999) entre vários pares de caracteres. Em geral, este fato tem sido atribuído ao número elevado de estimativas, associado com limitações impostos pelo modelo matemático.

Comparando os resultados da Tabela 20, observa-se que 13 correlações genotípicas, dentro do intervalo esperado, mostraram-se superiores e de mesmo sentido em relação às respectivas correlações fenotípicas. Com exceção de uma correlação genotípica, PCS x \%OL, que apesar da elevada magnitude, mostrou resposta contrária à correlação fenotípica; uma segunda exceção, NTV x PV, mostrou correlação genotípica menor que a correlação fenotípica.

Algumas correlações genotípicas podem fornecer interpretações aplicadas muito interessantes no grupo de progênies. Utilizando-se o mesmo critério discutido para as correlações fenotípicas, com base nas correlações genotípicas também foram 
estabelecidas três classes: caracteres não-associados $(-50 \%<\mathrm{r}<50 \%)$, caracteres associados negativamente $(r \leq-50 \%)$ e caracteres associados positivamente $(r \geq 50 \%)$.

\subsubsection{Caracteres não-associados}

Esta classe inclui 16 das 45 recombinações de caracteres: PR x LVV, PR x PCS, PR x NTV, PR x \%V2, PR x PV, LVV x PG, LVV x \%OL, PG x PCS, PG x \%V1, PCS x \%V1, \%OL x \%V2, NTV x \%V2, NTV x \%V3, \%V1 x \%V3, \%V2 x PV e \%V3 $\mathrm{x}$ PV. Para estes caracteres não-associados, a discussão seguinte deve ser considerada apenas em termos de tendências gerais.

Entre PR e PCS e entre PR e NTV, as correlações genotípicas apresentaram sentido contrário às fenotípicas, respectivamente, $-31,50 \%$ e 7,24\%, e 8,69 e -0,96\%.

As correlações genotípicas entre LVV e os caracteres PG e \%OL, apresentaram sentidos opostos às correlações fenotípicas; para LVV x PG, correlações de $-34,93 \%$ e $2,74 \%$ e para LVV x \%OL, $-33,99 \%$ e $6,61 \%$.

A correlação entre PG e PCS mostrou estimativa de $26,0 \%$ entre estes caracteres. Este resultado concorda com Santos (1988) que obteve correlação de 41,7\%. Pacova (1992) em $F_{3}$, trabalhando com 40 parentais, 57 topocruzamentos de sementes grandes e sete genótipos de sementes pequenas obteve resultados bem divergentes, respectivamente, $-51,0 \%,-27,0 \%$ e $95,0 \%$; portanto, nos dois primeiros grupos, aumento de peso, associou-se a uma diminuição no tamanho das sementes (PCS) para o grupo de sementes grandes. Yokomizo (1999) em $\mathrm{F}_{9: 4}$, trabalhando com topocruzamentos de sementes grandes, obteve correlação de $-44,88 \%$. Trabalhos de diverso autores indicam que esta correlação é indefinida (Johnson et al., 1955; Anand \& Torrie, 1963; Kwon \& Torrie, 1964; Santos et al., 1995), confirmando a classificação como caracteres nãoassociados.

A correlação LVV x \%V3 mostrou estimativa de $-33,99 \%$, indicando que quando há um aumento na LVV, ocorre uma diminuição no número de vagens com três ou mais sementes. Santos (1988), obteve correlação genotípicas para LVV e \%OL da ordem de $-18,0 \%$. 
A correlação \%V1 x \%V3 mostrou estimativas d $-47,67 \%$, indicando que quando há um aumento no número de vagens com três ou mais vagens, ocorre uma diminuição no número de vagens com uma semente. Esta correlação é vantajosa comercialmente, pois aumenta a qualidade da soja para edamame.

As correlações \%V2 x PV e \%V3 x PV, mostraram, respectivamente, estimativas de $42,75 \%$ e $-23,20 \%$. Portanto, com o aumento no peso de vagens, ocorreu um aumento no número de vagens com duas sementes e uma diminuição no número de vagens com três sementes.

\subsubsection{Caracteres associados negativamente}

Nesta classe foram incluídas apenas sete combinações de caracteres: PR $\mathrm{x}$ \%OL, PR x \%V3, LVV x \%V3, PG x \%V3, PCS x \%OL, PCS x \%V3 e \%V2 x \%V3.

As estimativas das correlações genotípicas entre PR e os caracteres \%OL e $\% \mathrm{~V} 3$, apresentaram magnitudes superiores às encontradas para as respectivas correlações fenotípicas. Para PR x \%OL e PR x \%V3, as correlações genotípicas foram, respectivamente, $-63,80 \%$ e $-65,15 \%$. Pacova (1992) obteve para as correlações entre PR e os caracteres LVV, PG e PCS, respectivamente, $46,0 \%, 72,0 \%$ e $1,0 \%$, sendo que apenas este última é não-significativa. Montaño-Velasco (1992) obteve correlação entre PR e \%OL próxima de zero (-1,70\%), indicando baixa correlação genotípica entre estes caracteres.

A correlação entre PCS e \%OL mostrou elevada magnitude, com estimativa

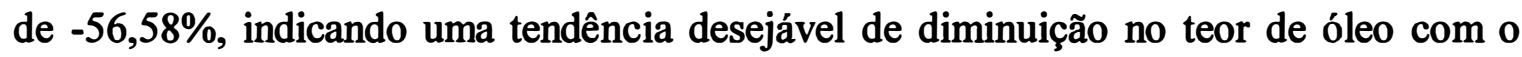
aumento do tamanho da semente. Santos (1988) obteve, para esta mesma correlação, estimativa de $-22,2 \%$. Resultados semelhantes foram obtidos por Byth et al. (1969) e Miranda (1994). Todavia, correlações positivas foram obtidas por Johnson et al. (1955b); Byth et al. (1969), Know \& Torrie (1964), Smith \& Circle (1972); Reddy et al. (1989); Pantalone et al. (1996) e Marega Filho (1999).

A correlação PG x \%V3, mostrou magnitude de $-77,10 \%$. Portanto, com o aumento da produtividade de grãos ocorre uma diminuição no número de vagens com três ou mais sementes. 


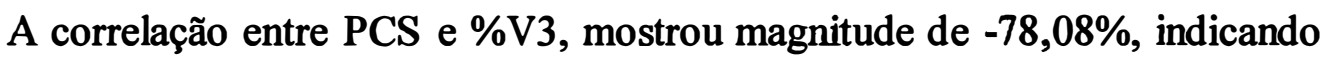
tendência do aumento no tamanho das sementes proporcionar diminuição acentuada no número de vagens com três ou mais sementes. Isto pode ser verificado na testemunha Tamba, que apresentou o maior PCS, maior \%V1 e menor \%V3.

A correlação entre \%V2 x \%V3 mostrou estimativa de $-83,05 \%$, indicando que com o aumento no número de vagens com três ou mais vagens, ocorreu uma diminuição acentuada no número de vagens com duas sementes. Esta correlação é desvantajosa, pois não permite elevar o número de vagens com mais de duas sementes ao mesmo tempo em que se eleva o número de vagens com três ou mais sementes.

\subsubsection{Caracteres associados positivamente}

Esta classe incluiu apenas três combinações de caracteres: LVV $x$ \%V1, \%OL x \%V3 e NTV x PV.

A correlação LVV x PCS mostrou estimativa maior que 100\%. Pacova (1992) em $\mathrm{F}_{3}$, obteve para LVV x PCS estimativa de 82,0\%, em topocruzamentos com Doko, concordando com valores obtido por Yokomizo (1994) em $F_{5: 4}$ e Yokomizo (1999) em F9:4.

A correlação entre \%OL e \%V3 mostrou estimativa de 96,21\%, indicando que o aumento no teor de óleo das sementes foi acompanhado pelo aumento no número de vagens com três ou mais sementes. Para soja do tipo edamame estas correlações são desvantajosas, pois elevados teores de óleo diminuem a palatabilidade do produto. Para a produção de tofu, elevados teores de óleo são desejáveis, juntamente com elevados teores de proteína.

\subsection{Seleção de progênies para usos alimentares específicos}

Para consumo como alimento, a soja deve apresentar características específicas para cada tipo de consumo: salada, edamame, doce, tofu, misso, natto, broto de soja, entre outras. Como se trabalhou apenas com progênies de sementes grandes, o tipo natto e o tipo broto estão automaticamente excluídos. 
Deve-se também considerar que a diferenciação das progênies de acordo com os usos alimentares específicos poderá no futuro ser aperfeiçoado com a obtenção e adição na discussão de dados experimentais sobre caracteres não disponíveis como: teor e qualidade de proteína, qualidade de óleo e análises organolépticas. Todavia, pelo menos preliminarmente, pode-se aceitar que o fato desta pesquisa ter se limitado ao germoplasma com sementes grandes aumenta a possibilidade das progênies produzirem alimentos de bom sabor e aroma. Tal expectativa é verdadeira por que nas sementes grandes a relação entre eixo embrionário e cotilédones é menor e, consequentemente, também deverão ser menores as quantidades relativas de ácido linolênico e de isoflavonóides, substâncias estas que conferem sabor e odor desagradáveis ("beany flavour" ou "feijão cru", características da soja tipo grão com sementes de tamanho médio a pequeno) (Hildebrand et al., 1988).

\subsubsection{Soja tipo salada}

A soja usada na forma de salada envolve grãos maduros cozidos, misturados com outros legumes e consumidos como prato frio.

Para consumo na forma de salada, Yokomizo (1999) utilizou como critérios: PCS e PG da testemunha Nimame como valores mínimos, cor do tegumento amarelo e cor do hilo creme ou marrom. As médias obtidas para os ambientes foram PCS $=17,25$ $\mathrm{g} / 100$ sementes e $\mathrm{PG}=91,0 \mathrm{~g} /$ planta; a média do PCS foi muito próximo ao valor alcançado por Yokomizo (1999) em $\mathrm{F}_{9: 4}$, enquanto que a $\mathrm{PG}$ atingiu o dobro em relação àquela alcançada por este autor.

No caso da produção ser destinada à exportação para mercados consumidores tradicionais como o Japão e outros países orientais, a cor do tegumento amarelo tornou-se primordial; mas, alguns mercados consumidores aceitam grãos de soja de sementes verdes na forma de salada, independentemente da cor do hilo.

A escolha de Nimame como critério é extremamente conveniente, pois o nome do cultivar em japonês significa "grão cozido", indicando possivelmente a forma de consumo como salada. Utilizando o grupo do teste de Scott-Knott que incluiu a testemunha Nimame para PCS e PG mínimos, a seleção salada resultou em nove 
progênies divididas em dois grupos: o primeiro com sementes amarelas, principalmente para exportação, composta por quatro progênies; e um segundo grupo com sementes verdes, para exportação para mercados específicos ou para o mercado interno, por exemplo, em substituição à ervilha, formado por cinco progênies, a partir dos dados das Tabelas 5, 14 e 21 .

\begin{tabular}{|c|c|c|c|c|c|c|c|c|}
\hline \multicolumn{9}{|c|}{ Seleça Salada } \\
\hline \multicolumn{2}{|c|}{ Progênies Selecionadas } & \multirow{2}{*}{\multicolumn{3}{|c|}{ Cruzamentos }} & \multirow{2}{*}{$\begin{array}{c}\text { PCS } \\
g / 100 \mathrm{~s} .\end{array}$} & \multirow{2}{*}{$\begin{array}{c}\text { PG } \\
\text { g/planta }\end{array}$} & \multicolumn{2}{|c|}{ Cor } \\
\hline N. ${ }^{\circ}$ & N. USP & & & & & & tegumento & Hilo \\
\hline \multicolumn{9}{|c|}{ Grupo I - Semente Amarelas } \\
\hline 2 & USP98-06002 & PI 80.441 & $\mathbf{x}$ & Doko & 22,9 & 139,8 & Amarelo fosco & Marrom \\
\hline 5 & USP98-06005 & $(\mathrm{TN \# 4}$ x PI230.970F $7-4)$ & $\mathbf{x}$ & Doko & 23,8 & 130,5 & Amarelo fosco & Creme \\
\hline 7 & USP98-06008 & (64-54 x KS 473 & $\mathbf{x}$ & Doko & 18,8 & 122,8 & Amarelo fosco & Marrom \\
\hline 28 & USP98-06029 & Majos & $\mathbf{x}$ & Doko & 18,6 & 108,4 & Amarelo fosco & Marrom \\
\hline \multicolumn{9}{|c|}{ Grupo 2 - Sementes Verdes } \\
\hline 11 & USP98-06012 & Late Giant & $\mathbf{x}$ & Doko & 22,9 & 126,5 & Amarelo esverdeado & Preto \\
\hline 13 & USP98-06014 & Late Giant & $\mathbf{x}$ & Doko & 22,3 & 177,9 & Verde fosco & Preto/Marrom \\
\hline 19 & USP98-06020 & Japão 1 & $\mathbf{x}$ & Doko & 25,6 & 139,7 & Verde fosco & Preto \\
\hline 20 & USP98-06021 & Japão 2 & $\mathbf{x}$ & Doko & 23,9 & 122,3 & Verde fosco & Preto/Marrom \\
\hline 33 & USP98-06034 & PI 229.320 & $\mathbf{x}$ & Doko & 20,9 & 121,4 & Amarelo fosco & Marrom/Creme \\
\hline
\end{tabular}

Das progênies selecionadas por Yokomizo (1999), apenas USP98-06029 foi novamente incluída nesta seleção, duas progênies foram descartadas por possuírem hilo preto/marrom (USP98-06008 e USP98-06009) e outras duas progênies foram preteridas por apresentarem PG abaixo do grupo de Scott-Knott de Nimame (USP98-06027 e USP98-060031).

Yokomizo (1999) observou que as progênies USP98-06008 e USP98-06009, por apresentarem sementes com hilo preto e marrom, precisavam passar por uma seleção adicional em favor das que possuem hilo marrom. Mas segundo Kiihl ${ }^{1}$ (comunicação pessoal), é possível que uma progênie possua genótipo para hilo preto, mas devido às condições ambientais, acaba apresentando tonalidade mais clara, daí a variação de cores dentro da progênie.

${ }^{1}$ Kiihl, R. S. A. (EMBRAPA. Centro Nacional de pesquisa de Soja, Londrina). Reunião técnica do Serviço Nacional de Proteção de Cultivares, 24 e 25/02/2000. Londrina. 
Para esta seleção as plantas podem ser semeadas da mesma forma que a soja do tipo grão(fileiras contínuas e espaçadas 50 a $60 \mathrm{~cm}$ ); apesar desta prática de cultivo diminuir a produtividade por planta, ela permite um aumento de produção por área, e não altera o tarnanho das sementes, pois este caráter é pouco influenciado pelo ambiente.

\subsubsection{Soja tipo doce}

A soja tipo doce é consumida na forma de grãos maduros rehidratados, cozidos no vapor e recobertos com açúcar ou confeitos. No Japão, este tipo de soja é conhecido como "Kuromame", ou seja, "grão preto". Deste grupo o cultivar padrão conhecido é "Tambaguro Daizu"; no Brasil mais conhecido como Tamba; incluído como testemunha nesta pesquisa, o cultivar Tamba apresentou elevado PCS (27,0 g/100 sementes), tegumento e hilo pretos.

Yokomizo (1999) selecionou progênies que possuem sementes grandes, com tegumento e hilo preto. Para esta seleção, foram usados os mesmos critérios utilizados por este autor, além de produtividade de grãos maior que $100 \mathrm{~g} /$ planta e PCS maior que $20,0 \mathrm{~g} / 100$ sementes, pois nenhuma progênie apresentou PCS maior que Tamba. Desta maneira, a seleção doce resultou em sete progênies selecionadas a partir dos dados das Tabelas 5,17 e 21 .

\begin{tabular}{|c|c|c|c|c|c|c|c|c|}
\hline \multicolumn{9}{|c|}{ Seleção Doce } \\
\hline \multicolumn{2}{|c|}{ Progênies Selecionadas } & \multirow{2}{*}{\multicolumn{3}{|c|}{ Cruzamentos }} & \multirow{3}{*}{$\begin{array}{c}\begin{array}{c}\text { PCS } \\
\mathrm{g} / 100 \mathrm{~s} .\end{array} \\
23,5\end{array}$} & \multirow{3}{*}{$\begin{array}{c}\begin{array}{c}\text { PG } \\
\text { g/planta }\end{array} \\
100,1\end{array}$} & \multicolumn{2}{|c|}{ Cor } \\
\hline N. ${ }^{\circ}$ & N. USP & & & & & & tegumento & Hilo \\
\hline 9 & USP98-06010 & PI 230.977 & $x$ & Doko & & & Preto brilhante & Preto \\
\hline 12 & USP98-06013 & Late Giant & $\mathbf{x}$ & Doko & 24,3 & 167,9 & Preto fosco & Preto \\
\hline 16 & USP98-06017 & Late Giant & $\mathbf{x}$ & Doko & 24,7 & 174,1 & Preto fosco & Preto \\
\hline 17 & USP98-06018 & Late Giant & $\mathbf{x}$ & Doko & 21,5 & 174,1 & Preto brilhante & Preto \\
\hline 22 & USP98-06023 & Aliança Preta & $\mathbf{x}$ & Doko & 23,7 & 108,4 & Preto brilhante & Preto \\
\hline 23 & USP98-06024 & Aliança Preta & $\mathbf{x}$ & Doko & 21,9 & 149,2 & Preto brilhante & Preto \\
\hline 24 & USP98-06025 & Aliança Preta & $\mathbf{x}$ & Doko & 22,4 & 160,6 & Preto fosco & Preto \\
\hline
\end{tabular}

Comparando com resultados de Yokomizo (1999), verifica-se que quatro progênies foram incluídas nas duas seleções: USP98-06013, USP98-06017, USP98- 
06018 e USP98-06025. A progênie USP98-06014 não foi incluída nesta seleção por apresentar PG menor que $100 \mathrm{~g} /$ planta.

Observa-se que as sete progênies selecionadas são originárias de apenas três cruzamentos, sendo três são originárias do cruzamento Late Giant x Doko, e três do cruzamento Aliança Preta x Doko; portanto, este grupo de seleção apresenta base genética bastante estreita.

Para a soja tipo doce, o plantio comercial deve ser realizado em covas, seja através de mudas transplantadas, ou através da semeadura de várias sementes por cova e desbaste para deixar uma única planta por cova (método SHDT, Vello, 1992a); o espaçamento deve ser grande ( $\geq 60 \mathrm{~cm} \times 60 \mathrm{~cm}$ ), a fim de facilitar os tratos culturais e para que as sementes possam crescer sem restrições de nutrientes e de luz. Este tipo de soja é propícia à exportação por se tratar de sementes maduras, que não necessitam de contêiners refrigerados, além de possuir um elevado preço no mercado japonês.

\subsubsection{Soja tipo hortaliça ou edamame}

A soja tipo hortaliça é chamada de edamame no Japão e compreende vagens imaturas (estádio $\mathrm{R}_{6}$ de Fehr \& Caviness, 1977), comercializada na forma de maços de várias plantas desfolhadas e contendo caule, ramos e vagens imaturas. Para exportação as vagens devem ser colhidas verdes, acondicionadas em sacos plásticos à vácuo $\mathrm{e}$ congeladas, necessitando por isso de contêiners refrigerados ou navios frigoríficos; possuem, também, um preço elevado no mercado japonês, que os importa da Austrália, Estados Unidos e principalmente de Taiwan.

Segundo Shanmugasundaram et al. (1989), morfologicamente as vagens devem ser grandes e apresentar pubescência branca, preferencialmente lisas; o hilo deve ser marrom claro ou cinza e as vagens devem apresentar duas ou três sementes; sem restrição para a cor do tegumento. Como padrão de soja tipo hortaliça foi utilizada a testemunha IAC PL-1, por possuir hilo marrom e pubescência cinza, PCS próximo a $25,0 \mathrm{~g} / 100$ sementes e média baixa de \%V1. Uma única progênie classificou-se com características de soja tipo hortaliça, selecionada a partir dos dados das Tabelas 5, 17 e 21. 


\begin{tabular}{|c|c|c|c|c|c|c|c|}
\hline \multicolumn{8}{|c|}{ Seleção hortaliça ou edamame } \\
\hline Progênie Selecionada & & & PCS & PG & $\%$ & & \\
\hline N. USP & \multicolumn{2}{|l|}{ Cruzamento } & $g / 100 \mathrm{~s}$. & g/planta & $(\mathrm{V} 2+\mathrm{V} 3)$ & Hilo & Pubescência \\
\hline USP98-06005 & $(\mathrm{TN} \# 4 \times$ PI230.970F 74$)$ & x Doko & 23,8 & 130,5 & 83,6 & Creme & Cinza \\
\hline
\end{tabular}

O principal fator restritivo para esta seleção foi a necessidade da cor do hilo ser marrom claro ou cinza e ter pubescência branca ou cinza. Esta último caráter é um fator muito importante para o consumidor japonês, uma vez que catálogos japoneses sempre trazem a cor da pubescência em destaque; provavelmente, isto se deve ao fato de que cores escuras de pubescência dariam um aspecto manchado às vagens verdes.

Se os caracteres cor de hilo e da pubescência forem desconsiderados, diversas progênies poderiam ser incluídas no grupo hortaliça ou edamame, por apresentarem elevados valores de PCS, PG e (\%V2 + \%V3). Neste grupo seriam incluídas oito progênies selecionadas a partir dos dados das Tabelas 5, 17 e 21 .

\begin{tabular}{|c|c|c|c|c|c|c|c|c|}
\hline \multicolumn{9}{|c|}{ Seleção hortaliça ou edamame (excluindo cor de hilo e pubescência como restrição) } \\
\hline \multicolumn{2}{|c|}{ Progênies Selecionadas } & \multirow{2}{*}{\multicolumn{2}{|c|}{ Topocruzamentos }} & \multirow{3}{*}{$\begin{array}{c}\begin{array}{c}\text { PCS } \\
\mathrm{g} / 100 \mathrm{~s} .\end{array} \\
23,4\end{array}$} & \multirow{3}{*}{$\begin{array}{c}\begin{array}{c}\text { PG } \\
\text { g/planta }\end{array} \\
127,8\end{array}$} & \multirow{3}{*}{$\begin{array}{c}\begin{array}{c}\% \\
(V 2+V 3)\end{array} \\
81,9\end{array}$} & \multicolumn{2}{|c|}{ Cor } \\
\hline N. ${ }^{\circ}$ & N. USP & & & & & & Hilo & Pubescência \\
\hline 3 & USP98-06003 & (TK35 x Unknown F ) & x Doko & & & & Preto & Marrom \\
\hline 12 & USP98-06013 & Late Giant & x Doko & 24,3 & 167,9 & 79,8 & Preto & Marrom \\
\hline 16 & USP98-06017 & Late Giant & x Doko & 24,7 & 156,4 & 85,4 & Preto & Marrom \\
\hline 18 & USP98-06019 & Japão 1 & x Doko & 24,1 & 111,1 & 83,8 & Preto & Marrom \\
\hline 19 & USP98-06020 & Japão 1 & x Doko & 25,6 & 139,6 & 78,0 & Preto & Cinza \\
\hline 20 & USP98-06021 & Japão 2 & x Doko & 23,9 & 122,3 & 85,0 & Preto & Marrom \\
\hline 22 & USP98-06023 & Aliança Preta & x Doko & 23,7 & 108,4 & 83,3 & Preto & Marrom \\
\hline 30 & USP98-06031 & PI 165.672 & x Doko & 24,3 & 116,4 & 89,5 & Marrom & Marrom \\
\hline
\end{tabular}

Quando se desconsiderou a cor do hilo e da pubescência, a seleção edamame incluiu oito progênies, com destaque para aquelas originárias do cruzamento Late Giant x Doko (USP98-06013 e USP98-06017), que apresentaram PG bem acima da média da seleção. Destaca-se também a progênie USP98-06020 (Japão 1 x Doko) pelo elevado PCS (acima de 25,0g /100 sementes).

Este tipo de soja requer o mesmo tratamento de uma hortaliça, sendo geralmente semeada em canteiros, e transplantadas para covas no campo. Após a granação (estádio $\mathrm{R}_{6}$ de Fehr \& Caviness, 1977), e antes da colheita, as folhas do terço 
superior da planta são removidas para que as vagens fiquem completamente verdes (Konovsky et al., 1994).

\subsubsection{Soja tipo tofu e extrato}

Tanto para a preparação de tofu (coalho ou queijo de soja) quanto para extrato (leite de soja), a soja participa na forma de grãos maduros, cozidos, hidratados e moídos. Taira (1990) encontrou uma alta correlação entre as composições químicas do tofu e do extrato de soja. Segundo Lin et al. (1990) o rendimento do tofu não é afetado pelo tamanho da semente. Bemard (1999), menciona ser desejável que os cultivares apresentem alto teor de proteínas, cor amarela e hilo claro. Como teor de óleo está negativamente correlacionado com o teor de proteína, $\mathrm{r}=-0,60$ em média (Brim, 1973; Marschalek, 1995; Marega Filho, 1999), e que alto teor de óleo também envolve alta concentração do ácido linolênico e, portanto, sabor e odor desagradáveis (Rackis et al., 1970; Della Modesta \& Garrutti, 1982; Azevedo, 1987; Fehr, 1992), o primeiro critério adotado para a seleção de soja tipo tofu e extrato de soja foi o baixo teor de óleo (grupo $\mathrm{D}$ da classificação de Scott-Knott, Tabela 17). Também foram incluídos como requisitos tegumento amarelo e hilo claro. Dessa maneira, a seleção tofu e extrato de soja resultou em sete progênies selecionadas a partir dos dados das Tabelas 5, 17 e 21 .

\begin{tabular}{|c|c|c|c|c|c|c|c|}
\hline \multicolumn{8}{|c|}{ Seleção tofu e extrato de soja } \\
\hline \multicolumn{2}{|c|}{ Progênies Selecionadas } & \multirow{2}{*}{\multicolumn{2}{|c|}{ Cruzamentos }} & \multirow{3}{*}{$\frac{\% O L}{16,7}$} & \multirow{3}{*}{$\begin{array}{c}\begin{array}{c}\text { PG } \\
\text { g/planta }\end{array} \\
67,9\end{array}$} & \multicolumn{2}{|c|}{ Cor } \\
\hline N. ${ }^{\circ}$ & N. USP & & & & & Tegumento & Hilo \\
\hline 1 & USP98-06001 & PI 229.320 & x Doko & & & Amarelo & Marrom \\
\hline 7 & USP98-06008 & $(64-64 \times \mathrm{KS} \mathrm{473)}$ & x Doko & 17,4 & 122,8 & Amarelo fosco & Marrom \\
\hline 29 & USP98-06030 & Majos & x Doko & 16,9 & 98,81 & Amarelo fosco & Marrom \\
\hline
\end{tabular}

Dentro desta seleção, destacou-se a progênie USP98-06008 que apresentou baixo teor de óleo associado a uma boa produtividade. Contrariamente, a progênie USP98-06001 apresentou o mais baixo teor de óleo, mas, também, foi a de mais baixa produtividade entre as 33 progênies avaliadas.

Assim como a soja tipo salada, a soja tipo tofu e extrato também pode ser cultivada como soja tipo grão, uma vez que as características desejáveis para este tịo de 
soja alimento são tegumento amarelo, hilo claro e alto teor de proteína (ou baixo teor de óleo).

\subsection{Considerações finais}

Diferenças encontradas entre médias e correlações em relação às pesquisas de Santos (1988), envolvendo alguns parentais utilizados nos trabalhos subseqüentes, Destro (1991) em $F_{2}$, Pacova (1992) em $F_{3}$, Yokomizo (1994) em $F_{5: 4}$ e Yokomizo (1999) em $\mathrm{F}_{9: 4}$, devem ser causadas por fatores genéticos, uma vez que a contínua seleção realizada ao longo das gerações pesquisadas pelos autores anteriormente citados, melhoraram as qualidades inerentes à soja, resultando ao final do trabalho em progênies selecionadas com elevada produtividade de grãos, boas características de semente e possivelmente características alimentícias desejáveis. Apesar das várias gerações de seleção, as progênies ainda mostraram variabilidade para alguns caracteres, principalmente para aqueles que não tinham sido avaliados anteriormente, o que possibilita ainda encontrar genótipos segregantes. Assim, indica a possibilidade de ganhos com gerações futuras.

Conforme foi discutido ao longo deste trabalho, parte das diferenças encontradas são devidas às condições ambientais, como clima e solo. Além disso, parte das diferenças poderiam ter sido causadas por um fator não avaliado por nenhum trabalho com soja tipo alimento, que são as variações devidas às diferentes densidades de semeadura utilizadas pelos autores anteriormente citados. Santos (1988) utilizou parcelas com uma fileira de 5,0m, com área útil de $4,6 \mathrm{~m}$ e avaliou dez plantas aleatoriamente; Destro (1991), utilizou o SHDT [Single Hill Descent Thinned (Vello 1992a, 1992b)] em parcelas de 12 covas espaçadas 0,60m x 0,60m; Pacova (1992), utilizou o SHD (Single Hill Descent) com parcelas com 12 covas, várias (até 12) plantas por cova, espaçamento de 0,30m entre plantas e 0,60m entre fileiras; Yokomizo (1994), utilizou o SHD (Single Hill Descent) em parcelas com 12 covas, várias (até 12) plantas por cova, espaçamento de 0,50m x 0,50m; e Yokomizo (1999), realizou semeadura em copinhos e transplantes de mudas para parcelas com dez covas de plantas individuais espaçadas $0,50 \mathrm{~m} \times 0,50 \mathrm{~m}$, uma técnica com resultados semelhantes ao SHDT. 
Segundo Urben Filho \& Souza (1993) a combinação da densidade de plantas na fileira de semeadura com o espaçamento entre fileiras define a população de plantas da cultura, a qual influencia algumas características agronômicas da planta de soja, bem como, pode modificar a produtividade de grãos. Lan-Sanchez \& Veloso (1974) e Nakagawa et al. $(1986,1987)$ verificaram que a densidade de plantas influenciou positivamente a altura da planta e a inserção da primeira vagem e, negativamente, o diâmetro e o número de vagens por planta. Apesar disso, Cartter \& Hartwig (1967) verificaram que a cultura da soja é muito pouco afetada por variações na densidade de plantas na fileira de semeadura, já que a planta possui elevada capacidade de compensação e ajuste dos componentes da produtividade.

O fenótipo de cada indivíduo de uma população reflete as influências genéticas e não-genéticas sobre o seu desenvolvimento. As influências não-genéticas são determinadas pelo ambiente, o qual pode estar associado a uma localidade ou a um certo período de tempo (Vernetti et al., 1990). Segundo estes autores, a interação G x E reduz a correlação entre o fenótipo e seu genótipo, restringindo a validade das interferências sobre o seu comportamento, tanto do ponto de vista do comportamento genético como da herança de caracteres quantitativos. Dashiell et al. (1994) sugere que os genótipos não reagem da mesma forma em todas as localidades, possivelmente devido ao ambiente ou à interação G x E. Soares et al. (1995) afirma que ambientes favoráveis permitem maior discriminação entre linhagens, devido favorecer a maximização da variabilidade genética entre elas. Isto explica por que Anhembi mostrou maiores médias entre os 18 caracteres avaliados em relação a ESALQ, embora isto contraste com resultados obtidos por Yokomizo (1999) em $\mathrm{F}_{9: 4}$, pelos quais a ESALQ permitiu melhor diferenciação entre os caracteres.

A seleção das melhores progênies para uso como soja tipo alimento não impede que as mesmas também sejam cultivadas como soja tipo grão. Logicamente, tal utilização dependerá de futuras pesquisas para se avaliar o desempenho das progênies em sistema de cultivo tipo grão (semeadura em fileiras contínuas espaçadas de 50 a 60 $\mathrm{cm}$ ), principalmente no que se refere aos efeitos da interação genótipos $\mathrm{x}$ ambientes. As progênies selecionadas também poderão ser utilizadas como parentais em programas de 
melhoramento de soja tipo grão, no sentido de contribuírem para a ampliação da base genética da soja cultivada (Vello, 1992b), uma vez que os genótipos parentais exóticos tipo alimento aparentemente ainda não contribuíram com genes, pelo menos não intensamente, para os programas de melhoramento de soja tipo grão.

A possibilidade de se cultivar progênies avaliadas na forma de soja tipo grão e ou o emprego das mesmas como parentais para ampliação da base genética da soja cultivada também se aplica para aquelas progênies com menor tamanho de sementes( $<20 \mathrm{~g} / 100$ sementes), mas com alta produtividade de grãos, como é o caso das progênies n. 7 (USP98-06008), n..$^{0} 14$ (USP98-06015) e n. 28 (USP98-06029), caracterizadas na Tabela 17. 


\section{CONCLUSÕES}

Os resultados obtidos suportam as seguintes conclusões:

a) Várias das progênies superiores em $\mathrm{F}_{11: 4}$ já haviam se destacado em gerações anteriores como tipo alimento. Algumas progênies também mostraram potencial para cultivo ou uso como parentais em programas de melhoramento de soja tipo grão.

b) Existe variabilidade genética remanescente entre as progênies para alguns caracteres, o que viabiliza a obtenção de ganhos futuros por meio de seleção.

c) O local Anhembi mostrou-se mais favorável para a diferenciação da maioria dos caracteres, em relação ao local ESALQ.

d) A magnitude e o sinal das correlações entre caracteres não foram influenciados pelas diferenças entre locais, mas foram muito alterados pelos grupos de genótipos (testemunhas e progênies).

e) As correlações genotípicas entre caracteres foram superiores às fenotípicas e permitiram o estabelecimento de três níveis de associações: caracteres nãoassociados PR x LVV, PR x PCS, PR x NTV, PR x \%V2, PR x PV, LVV x PG, LVV x \%OL, PG x PCS, PG x \%V1, PCS x \%V1, \%OL x \%V2, NTV x \%V2, NTV $\mathrm{x} \% \mathrm{~V} 3, \% \mathrm{~V} 1$ x \%V3, \%V2 x PV e \%V3 x PV; caracteres associados negativamente: PR x \%OL, PR x \%V3, LVV x \%V3, PG x \%V3, PCS x \%OL, PCS x \%V3 e \%V2 x $\% \mathrm{~V} 3$; caracteres associados positivamente: LVV x \%V1, \%OL x \%V3 e NTV x PV.

f) Houve eficiência na seleção baseada nas classificações de Scott-Knott, nas médias dos caracteres, e nas características específicas mais relevantes para obtenção de quatro tipos de utilização (salada, doce, hortaliça e tofu/extrato de soja). Para uso como salada, foram formados dois subgrupos; o subgrupo de sementes amarelas, incluiu quatro progênies: USP98-06002, USP98-06005, USP98-06008 e USP9806029; e o subgrupo de sementes verdes, envolveu cinco progênies: USP98-06012, 
USP98-0614, USP98-06020, USP98-06021 e USP98-06034. Para uso como doce, foram selecionadas sete progênies: USP98-06010, USP98-06013, USP98-06017, USP98-06018, USP98-06023, USP98-06024 e USP98-06025. Para uso como hortaliça ou edamame, foram formados dois subgrupos; o subgrupo com sementes de hilo e pubescência claros, incluiu uma única progênie: USP98-06009; e no subgrupo de sementes de hilo e/ou pubescência escuros, foram selecionados oito progênies: USP98-06003, USP98-06013, USP98-06017, USP98-06019, USP98-06020, USP9806021, USP98-06023 e USP98-06031. Para uso como tofu e extrato de soja, a seleção incluiu três progênies: USP98-06001, USP98-06008 e USP98-06030. 


\section{REFERÊNCIAS BIBLIOGRÁFICAS}

ADLERCREUTZ, H. Western diet and western diseases: some hormonal and biochemical mechanism and associations. Scandinavian Journal of Clinic Laboratory Investigation, v.201, p.3-23, 1990. Suplemento 1

ANAND, S. C.; TORRIE, J. H. Heritability of yield and other traits and interrelationships among traits in the $\mathrm{F}_{3}$ and $\mathrm{F}_{4}$ generations of three soybean crosses. Crop Science, v.3, n.6, p.508-511, 1963.

AXELROD, B.; CHEESBROUGH, T. M.; LAAKSO, S. Lipoxigenases in soybean. Methods in Enzymology. v.71, p.441-451, 1981.

AZEVEDO, M. A. Seleção de variedades de soja (Glycine max (L) Merrill) viáveis ao consumo humano. Estudo sobre modificações sensoriais, químicas e nutricionais ocorridas durante o armazenamento. Campinas, 1987, 162p. Dissertação (Mestrado) Faculdade de Engenharia de Alimentos, Universidade Estadual de Campinas.

BAKHIT, R. M.; KELIN, B. P; ESSEX-SORLIE, D.; DAM, J. O.; ERDMAN, J. W. JR; POTTER, S. M. Intake of $25 \mathrm{~g}$ soybean protein with or without soybean fiber alters plasma lipids in men with elevated cholesterol concentrations. Journal of Nutrition, v.124, p.2130-222, 1994.

BARNES, S.; GRUBBS, C.; SETCHELL, K. D. R.; CARLSON, J. Soybeans inhibit mammary tumors in models of breast cancer. In: PRAIZA, M. W.; AESCHBACHER; H.; FELTON, J. S.; SATO, S. (Eds.) Mutagens and Carcinogens in the Diet. New York: Wiley-Liss, 1990. p.239-253.

BARNI, N. A.; GOMES, J. E. da S.; GONÇALVES, J. C. Influência do tamanho de semente, profundidade e densidade de semeadura sobre o rendimento de grãos de soja. In: SEMINÁRIO NACIONAL DE PESQUISA DE SOJA, Brasilia, 1981. Anais. Londrina; CNPSo - EMBRAPA, 1982. p.201-225. 
BARROS, E. G. de; MOREIRA, M. A.; FONTES, E. P. B. Atividades de Lipoxigenases $\mathrm{L}_{1}$ e $\mathrm{L}_{3}$ em cultivares comerciais de soja. Arquivo de Biologia e Tecnologia, v.27, n.3, p.381-386, 1984.

BERNARD, R. L. The inheritance of pod colors in soybeans. Journal of Heredity, v.58, n.4, p.165-168, 1967.

BERNARD, R. L. Two major genes for time of flowering and maturity in soybeans. Crop Science, v.11, p.242-244, 1971.

BERNARD, R. L. The inheritance of appressed pubescence. Soybean Genetics Newsletter, v.2, p.34-36, 1975.

BERNARD, R. L. Genetic improvement of food-type soybeans in the United States and Canada. In: CONGRESSO BRASILEIRO DE SOJA, Londrina, 1999. Anais. Londrina. CNPSo - EMBRAPA, 1999, p.93-98.

BONATO, E. R. Herança do tempo para o florescimento e para a maturidade em variantes naturais de soja [Glycine $\max (\mathrm{L}$.) Merrill]. Piracicaba, 1989. 166 p. Tese (Doutorado) - Escola Superior de Agricultura "Luiz de Queiroz", Universidade de São Paulo.

BONATO, E. R., VELLO, N. A. Aspectos genéticos do tempo para florescimento em variantes naturais de soja. Pesquisa Agropecuária Brasileira, v.34, n.6, p.989-993, 1999a.

BONATO, E. R., VELLO, N. A. $E_{6}$, a dominant gene conditioning early flowering and maturity in soybeans. Genetics and Molecular Biology, v.22, n.2, p.229-232, 1999b.

BRASIL, E. M. Comparação de métodos de controle da interação genótipo $\mathrm{x}$ ambiente em milho (Zea mays L.). Goiânia, 1990. 214p. Dissertação (Mestrado) Universidade Federal de Goiás.

BRAVO, J. A.; FEHR, W. R.; RODRIGUES DE CIANZIO, S. Use of pod width for indirect selection of seed weight in soybeans. Crop Science, v.20, p.507-510, 1980.

BRAVO, J. A.; FEHR, W. R.; RODRIGUES DE CIANZIO, S. Use of small-seeded soybean parents for the improvement of large seeded cultivars. Crop Science, v.21, p.430-432, 1981. 
BRIM, C. A. Quantitative genetics and breeding. In: CALDWELL, B. E. (Ed.) Soybeans: improvement, production and uses. 2.ed. Madison: American Society of Agronomy, 1973. cap. 5, p.155-186.

BRIM, C. A.; BURTON, J. W. Recurrent selection in soybeans. II. Selection for increased percent protein in seeds. Crop Science, v.19, p.494-498, 1979.

BUCKLE, T. S. Restrictions on using soya protein in foods in Latin America and the world. Journal of American Oil Chemistry Society, v.58, p.433-438. 1981.

BURTON, J. W. Quantitative genetics: results relevant to soybean breeding. In: WILCOX, J. R. (Ed.) Soybeans: improvement, production and uses. 2.ed. Madison: American Society of Agronomy, 1987. cap.6, p.211-247.

BUZZEL, R. I. Inheritance of soybean flowering response to fluorescent daylenght conditions. Canadian Journal of Genetics \& Cytology, v.13, p.703-707, 1971.

BUZZELL, R. I.; VOLDENG, H. D. Inheritance of insensitivity to long daylenght. Soybean Genetics Newsletter, v.7, p.26-29, 1980.

BYTH, D. E.; CALDWELL, B. E.; WEBER, C. R. Specific and non-especific index selection in soybeans, Glycine $\max$ (L.) Merrill. Crop Science, v.9, p.702-705, 1969.

CAMACHO, L. H. M. Varianzas genéticas y heredabilidad de características vegetativas y reproductivas de la soya Glycine max (L.) Merrill. Acta Agronomica, v.21, n.4, p.145-152, 1971.

CARRÃO-PANIZZI, M. C. Soja: proteína para milhões. Ciência Hoje, v.6, n.3, p.25$31,1987$.

CARRÃO-PANIZZI, M. C. Breeding soybean for human consumption. In: WORLD SOYBEAN RESEARCH CONFERENCE, 4, Buenos Aires, 1989. Proceedings. Buenos Aires: Associación Argentina de la Soja, 1989. v.2, p.1101-1105.

CARRÃO-PANIZZI, M. C.; DEGAWA, H.; SHIMANUKI, S.; TSUKAMOTO, C. Avaliação da cultivar BRS 155 para processamento de natto. In: CONGRESSO BRASILEIRO DE SOJA, Londrina, 1999. Anais. Londrina. Centro Nacional de Pesquisa de Soja - Embrapa, 1999, p.500.

CARROLL, K. K. Review of clinical studies on cholesterol-lowering response to soy protein. Journal of American Diet Association, v.1, p.820-286, 1991. 
CARTTER, J. L.; HARTWIG, E. E. The management of soybeans. In: NORMAN, A. G. (Ed.) The soybean. New York: Academic press, 1967. p.162-221.

CASSIDY, A., BINGHAM, S., SETCHELL, K. D. R., Biological effect of isoflavones present in soy in premenopausal women; implications for the prevention of breast cancer. American Journal of Clinical Nutrition, v.60, n.3, p.333-340, 1994.

CECON, P. R.; SEDIYAMA, C. S.; SEDIYAMA, T. Herdabilidade e correlações na geração $\mathrm{F}_{3}$ de dezesseis cruzamentos de soja. In: SEMINÁRIO DE PESQUISA DA SOJA, 3, Campinas, 1984a. Anais. Londrina, EMBRAPA/CNPSo, 1984a. p.346358.

CECON, P. R.; SEDIYAMA, C. S.; SEDIYAMA, T.; SILVA, J. C.; LUDWIG, A. Herdabilidade de alguns caracteres em gerações $F_{2}$ de cruzamentos de soja.. In: SEMINÁRIO DE PESQUISA DA SOJA, 3, Campinas, 1984b. Anais. Londrina, CNPSo - EMBRAPA, 1984b. p.338-345.

CHAUHAN, V. S.; SINGH, B. B. Genetic variability and heritability in soybean. Indian Journal of Agricultural Science, v.54, n.4, p.273-276, 1984.

CIANZIO, S. R. de, CAVINS, J. F.; FEHR, W. R. Protein and oil percentage of temperate soybean genotypes evaluated in tropical environments. Crop Science, v.25, p.602-606, 1985.

CRIWELL, J. G.; HUME, D. J. Variation in sensibility to photoperiod among early maturing soybean strains. Crop Science, v.12, p.657-660, 1972.

CROISSANT, G. L.; TORRIE, J. H. Evidence of nonadditive effects and linkage in two hybrid populations of soybeans. Crop Science, v.11, p.675-677, 1971.

CRUZ, C. D. Programa genes: aplicativo computacional em genética e estatística. Viçosa: Imprensa Universitária da UFV, 1997. 442p.

CRUZ, C. D.; REGAZZI, A. J. Interação genótipos x ambientes. In: CRUZ, C. D. \& REGAZZI, A. J. Modelos biométricos aplicados ao melhoramento genético. Viçosa: Imprensa Universitária da UFV, 1994. cap.1, p.1-34.

CRUZ, C. D.; TORRES, R. A. A.; VENCOVSKY, R. An alternative to the stability analysis proposed by Silva and Barreto. Revista Brasileira de Genética, v.12, p.567-580, 1989. 
D’UTRA, G. Soja. Jornal do Agricultor, v.7, p.185-188, 1882. (microfilme).

DAFFERT, F. W. Relatório anual do Instituto Agronômico do Estado de São Paulo. Campinas, 1982. 26p. (mimeografado).

DASHIEL, K. E.; ARIYO, O. J. BELLO, L.; OJO, K. Genotype $x$ environment interaction and simultaneous selection for high yield and stability in soybeans (Glycine max (L.) Merrill). Annals of Applied Biology, v.124, p.133-139, 1994.

DAWANDE, V. B.; THERE, D. N. Effect of seed size on yield in soybean (Glycine $\max ($ L.) Merrill). Journal of Soils and Crops, v.3, n.2, p.144-145, 1993.

DELLA MODESTA, R. C.; GARRUTI, R. S. Estudo sensorial e nutricional de diferentes cultivares de soja de 6 regiões brasileiras. Ciência e Tecnologia de Alimentos, v.2, p.47-56, 1982.

DESTRO, D. Capacidade de combinação de genótipos de soja [Glycine max (L.) Merrill] apropriados para o consumo humano. Piracicaba, 1991. 158p. Tese (Doutorado) - Escola Superior de Agricultura "Luiz de Queiroz", Universidade de São Paulo.

DESTRO, D.; SEDIYAMA, T.; GOMES, J. L. L. Genes qualitativos em soja: alguns comentários e listagem. Viçosa: Imprensa Universitária da UFV. 1990. 67p. (Boletim n. ${ }^{\circ}$ 293).

DESTRO, D.; SEDIYAMA, T.; SILVA, J. C.; SEDIYAMA, C. S.; THIÉBAUT, J. T. L. Estimativas de herdabilidade de alguns caracteres em dois cruzamentos de soja. Pesquisa Agropecuária Brasileira, v.22, p.3, p.291-304, 1987.

DUARTE, J. B.; VENCOVSKY, R. Interação genótipos x ambientes: uma introdução à analise "AMMI". Piracicaba, 1998. 58p.

DUARTE, J. B.; ZIMMERMANN, M. J. de O. Selection of locations for common bean (Phaseolus vulgaris L.) germoplasm evaluation. Revista Brasileira de Genética, v.14, n.3, p.765-770, 1991.

DWYER, J.; GOLDIN, B.; SAUL, N. Tofu and soy drinks contain phytoestrogens. Journal of American Diet Association, v.94, p.739-742, 1994.

EBERHART, S. A.; RUSSELL, W. A. Stability parameters for comparing varieties. Crop Science, v.6, p.36-40, 1966. 
EGLI, D. B. Rate of accumulation dry weight in soybeans and its relationship to yield. Canadian Journal of Plant Science, v.55, p.215-219, 1978.

FALCONER, D. S. Introduction to quantitative genetics. New York: Longman, 1989. 438p.

FAO FAOSTAT Data base e Results. http://www.fao.org/servlet/XteServlet.j...tion.Crops.Primary\&Outputlabel\&Language.

FARIAS NETO, J. T. Potencial de progênies $F_{4: 3}$ e $F_{5: 3}$ derivadas de cruzamentos em cadeia para produção de óleo em soja. Piracicaba, 1995. 150p. Tese (Doutorado) Escola Superior de Agricultura "Luiz de Queiroz", Universidade de São Paulo.

FEHR, W. R.; CAVINESS, C. E. Stages of soybean development. Iowa State University of Science and technology, 1977. 12p. (Special Report, 80).

FEHR, W. R.; WELKW, G. A.; HAMMOND, E. G.; DUVICK, D. N.; CIANZIO, S. R de Inheritance of reduced linolenic acid content in soybean genotypes A16 and A17. Crop Science, v.32, p.903-906, 1992.

FERRIER, L. K. Simple processing of whole soybeans. In: WHIGAHAN, D. K. (ed.) Soybean production, protection and utilization. Illinois, 1975, p.178-187.

FONTES, L. G.; ALMEIDA FILHO, J de, REIS, M. S.; SEDIYAMA, T.; SEDIYAMA, T. Conteúdo de óleo e proteína nos grãos e correlações com algumas características agronômicas de linhagens de soja. Revista Ceres, v.27, n.149, p.17-22, 1980.

FRANK, S. J.; FEHR, W. R. Association among pod dimensions and seed weight in soybeans. Crop Science, v.21, p.547-550, 1981.

FRASER, J.; EGLI, D. B.; LEGGETT, J. E. Pod and seed development in soybean cultivar with differences in seed size. Agronomy Journal, v.74, p.81-85, 1982.

FREIRE FILHO, F . R. Análise genética de um dialelo entre genótipos precoces de soja (Glycine max (L.) Merrill). Piracicaba, 1988. 224p. Tese (Doutorado) - Escola Superior de Agricultura “Luiz de Queiroz”, Universidade de São Paulo.

GILIOLI, J. L. Influência do tamanho da semente sobre algumas características agronômicas da soja. In: SEMINÁRIO NACIONAL DE PESQUISA DE SOJA, 1, Londrina, 1978. Anais. Londrina; CNPSo - EMBRAPA, 1979a. v.2, p.309-315. 
GILIOLI, J. L. Herança do número de dias para a floração e maturação em quatro mutantes naturais em soja (Glycine max (L.) Merrill). Viçosa, 1979b. 42p. Dissertação (Mestrado) - Universidade Federal de Viçosa.

GOLDENBERG, J. B. El empleo de la correlacion en el mejoramento genetico de las plantas. Fitotecnia Latinoamericana, v.5, n.2, p.1-8, 1968.

GOTOH, K. Historical review of soybean cultivation in Japan. Tropical Agriculture Research Series, v.17, p.135-142, 1984.

GRUNDY, S. N.; ABRAMS, J. J. Comparison of actions of soy protein and casein on metabolism of plasma lipoproteins and cholesterol in humans. American Journal of Clinical Nutrition, v.38, p.245-252, 1983.

GUPTA, A. K.; KAPOOR, M.; DEODHAR, A. D. Chemical composition and cooking characteristics of vegetable and grain-type soybeans. Journal of Food Science and Technology, v.13, p.133-137, 1976.

HAMAWAKI, O. T. Potencial de progênies selecionadas em cruzamentos óctuplos de soja com ênfase na produtividade de óleo. Piracicaba, 1998. 127p. Tese (Doutorado) - Escola Superior de Agricultura "Luiz de Queiroz", Universidade de São Paulo.

HAMMOND, E. G. Stability of soybean oil to oxidation. In: SHIBLES, R. (ed.) WORLD SOYBEAN RESEARCH CONFERENCE, 3, 1985. Westview. Proceedings. Westview, 1985. P.251-258.

HAMMOND, E. G.; DUVICK, D. N.; FEHR, W. R.; HILDEBRAND, D. F.; LACEFIELD, E. C.; PFEIFFER, T. W. Rapid screening techniques for lipoxigenases in soybean seeds. Crop Science, Madison, v.32, p.820-821, 1992.

HARRISON, S. A.; BOERMA, H. R.; ASHLEY, D. A. Heritability of canopy-apparent photosyntesis and its relationship to seed yield in soybeans. Crop Science, v.21, p.222-226, 1981.

HARTWIG, E. E. Varietal development. In: CALDWELL, B. E. (Ed.) Soybeans: improvement, production and uses. Madison: American Society of Agronomy. 1973. p.187-210.

HatanaKa, A. The biogeneration of green odor by green leaves. Phytochemistry, v.34, p.1201-1218, 1993. 
HEANEY, R. P., WEAVER, C. M., FITZSIMMONS, M. L. Soybean phytate content: effect on calcium absorption. American Journal of Clinical Nutrition, v.53, p.745747, 1991

HILDEBRAND, D. F.; HYMOWITZ, T. Two soybean genotypes lacking lipoxygenase-1. Journal American Oil Chemistry Society, v.58, p.583-586, 1981.

HILDEBRAND, D. F.; HAMILTON-KEMP, P.; LEGG, C. S.; BOKJANS, G. Plant lipoxygenases: occurrence, properties and possible functions. Current Topics in Plant Biochemistry and Physiology, v.7, p.201-219, 1988.

HINSON, K. Use a long juvenile trait in cultivar development. In: WORLD SOYBEAN RESEARCH CONFERENCE, 4, Buenos Aires, 1989. Proceedings... Buenos Aires: Associación Argentina de la Soja, 1989. v.2, p. 983-987

HIROMOTO, D. M. Parentais exóticos como fonte de genes para precocidade e produtividade da soja [Glycine max. (L.) Merrill]. Piracicaba, 1990. 110p. Dissertação (Mestrado) - Escola Superior de Agricultura "Luiz de Queiroz", Universidade de São Paulo.

HONG, E. H.; KIM, S. D.; HWANG, Y. H. Production and use of and research on soybeans in Korea. Tropical Agriculture Research Series, v.17, p.81-93, 1984.

HOWELL, R. W.; COLLINS, F. I. Factors affecting linoleic and linolenic acid content of soybean oil. Agronomy Journal, v.69, p.481-486, 1957.

HYMOWITZ, T.; COLLINS, F. I.; PANCZNER, J.; WALKER, W. M. Relationship between the content of oil, protein and sugar in soybean seed. Agronomy Journal, v.64, p.613-616, 1972.

IBGE Web site do Instituto Brasileiro de Geografia e Estatística. http://www.ibge.gov/estatistica/indicadores/agropecuária/lspa/defaut.shtm.

JANNACE, P. W.; LERMAN, R. H.; SANTOS, J. I.; VITALE, J. J. Effects of oral soy phosphatidylcholine on phagocytosis, arachidonate concentrations, and killing by human polymorphonuclear leukocytes. American Journal of Clinical Nutrition, v.56 p.599-603, 1992.

JIAN, Y. Y. Situation of soybean production and research in China. Tropical Agriculture Research Series, v.17, p.67-72, 1984. 
JOHNSON, H. W. Breeding for oil and protein in soybeans. Soybeans Digest, v.21, p.73-75, 1961.

JOHNSON, H. W.; ROBINSON, H. F.; COMSTOCK, R. E. Estimatives of genetic and environmental variability in soybeans. Agronomy Journal, v.47, p.314-323, 1955 .

JOHNSON, H. W.; ROBINSON, H. F.; COMSTOCK, R. E. Genotypic and phenotypic correlations in soybeans and their implications in selection. Agronomy Journal, v.47, p.477-483, $1955 b$.

KARAZAWA, T.; TANAKA, M.; UEMURA, T. Anti-atherogenecity of soybean protein. Annals of New York Academy Science, v.672, p.204-214, 1993.

KAW, R. N.; MENON, P. M. Association between yield and components in soybean. Indian Journal of Genetics \& Plant Breeding, v.32, p.276-280, 1972.

KENNEDY, A. R., SZUHAJ, B. F., NEWBERNE, P. M., BILLINGS, P. C. Preparation and production of cancer chemopreventive agent, Bowman-Birk inhibitor concentrate. Nutrition and Cancer, v.19, n.3, p.281-302, 1993.

KIIHL, R. A. S.; GARCIA, A. The use of the long juvenile trait in breeding soybean cultivars. In: CONFERÊNCIA MUNDIAL DE INVESTIGATION IN SOJA, 4, 1989, Buenos Aires. Anais. Buenos Aires: Associación Argentina de la Soja, 1989. p.994-1000.

KIIHL, R. S. A.; MIYASAKA, S.; MASCARENHAS, H. A. A. Contribuição à cultura da soja. O Agronômico, v.23, p.1-9, 1971.

KITAMURA, K. Biochemical characterization of lipoxigenase lacking mutants, L-1less and L-3-less soybeans. Agricultural Biological Chemistry, v.48, p.2339-2346, 1984.

KITAMURA, K. Breedings trials for improving the food processing quality of soybeans. Trends in Food Science Technology, v.4. p.64-67, 1993.

KITAMURA, K.; DAVIES, C. S.; KAIZUMA, N.; NIELSEN, N. C. Genetic analysis of a null-allele for lipoxygenase-3 in soybean seeds. Crop Science, v.23, p.924-927, 1983. 
KIUCHI, Y.; ISHIKAWA, H.; NITTA, N.; SASAKI, T. Collection of crop genetic resources and their characteristics in Iwate Prefecture. I. Characteristics of local soybean varieties. Tohoku Nogyo Kenkyu, v.40, p.139-140, 1987.

KONIECZNY, G.; MUSZYNSKI.; NAWRACALA, J. Variation of morphologic characteristics of soybean genotypes. Soybean Genetics Newsletter, v.21, p.142145, 1994.

KONO, S. Edamame. In: Enciclopédia de horticultura. V.6. Kabocha, endou, inden, soramame, edamame e outros grãos. Tokyo: Nosan Gyoson Bunka Kyokai, 1986. p.412-429.

KONOVSKY, J.; LUMPKIM, T. A. Edamame production and use: a global perspective. In: INTERNATIONAL CONFERENCE SOYBEAN PROCESSING AND UTILIZATION. Gongzhuling, 1990. Abstracts. Gongzhuling, Jilin Province, China, 1990. 12p.

KONOVSKY, J.; LUMPKIN, T. A.; McCLARY, D. Edamame: the vegetable soybean. In: O'ROURKE, A. D. (ed.) Understanding the japanese food and agrimarket: a multifaceted opportunity. Binghanton: Haworth Press, 1994. p.173-181.

KROONENBERG, P. M.; BASFORD, K. E. An investigation of multi-attribute genotype response across environments using three-mode principal component analysis. Euphytica, v.44, n.1-2, p.109-123, 1989.

KWON, S. H.; TORRIE, J. H. Heritability of and interrelationships among traits of two soybean populations. Crop Science, v.4, p.196-198, 1964.

LAÍNEZ-MEJ́A, J. R. Implicações da interação genótipos $\mathrm{x}$ ambientes na seleção de progênies de soja com ênfase nas produtividades de grãos e óleo. Piracicaba, 1996. 145p. Tese (Doutorado) - Escola Superior de Agricultura "Luiz de Queiroz", Universidade de São Paulo.

LAN-SÄNCHEZ, A.; VELOSO, E. J. Efeito do espaçamento e da densidade de plantio, sobre várias características agronômicas na cultura da soja (Glycine max (L.) Merrill), variedade "Viçoja" em Jaboticabal, SP. Científica, v.2. n.2, p.137-148, 1974.

LEE, H. P.; GOURLEY, L.; DUFFY, S. W.; ESTEVE, J.; LEE, J.; DAY, N. E. Dietary effects on breast cancer risk in Singapore. Lancet, v.337 p.1197-1200, 1991. 
LeROY, A. R., FEHR, W. R., CIANZIO, S. R de Introgression of genes for small seed size from Glycine soja into G. max. Crop Science, v,31, p.693-697, 1991.

LIN, B. T.; DE MAM, J. M.; BUZZEL, R. J. Yield and quality of tofu as affected by soybean and soymilk characteristics; calcium sulfate coagulant. Journal of Food Science, v.55, n.4, p.1088-1092, 1111, 1990.

LIU, K. Immature soybeans: direct use for food. Inform, v.7, n.11, p.1217-1223, 1996.

LO, G. S.; GOLDBERG, A. P.; LIM, A.; GRUNDHAUSER, J. J.; ANDERSON, C.; SCHONFELD, G. Soy fiber improves lipid and carbohydrate metabolism in primary hyperlipidemic subjects. Atherosclerosis. v.62, p.239-248, 1983.

LYNCH, S. R.; DASSENKO, S. A.; MORCH, T. A.; BEARD, J. L.; COOK, J. D. Soy protein products and heme iron absorption in human. American Journal of Clinic Nutrition, v.4, p.13-20, 1985.

MACFARLANE, B. J.; VAN DER RIET, E. W.; BOTHWELL, T. H.; BAYNES, R. D.; SIEGENBERT, D.; SCHMIDT, U.; TAL, A.; TAYLOR, J. R. N.; MAYET, F. Effect of traditional oriental soy products on iron absorption. American Journal of Clinical Nutrition, v.51 p.873-880, 1990.

MAREGA FILHO, M. Relações entre os teores de óleo, proteína e tamanho das sementes em soja. Londrina, 1999. 82p. Dissertação (mestrado) - Universidade Estadual de Londrina / Centro Nacional de Pesquisa de Soja - EMBRAPA / Instituto Agronômico do Paraná.

MARSCHALEK, R. Correlações genéticas e fenotípicas entre produção de grãos, teor de proteína e teor de óleo em soja, em vários ambientes. Piracicaba, 1995. 103p. Dissertação (Mestrado) - Escola Superior de Agricultura "Luiz de Queiroz", Universidade de São Paulo.

MASCARENHAS, H. A. A.; QUAGGIO, J. A.; HIROCE, R.; MIRANDA, M. A.C. de, TEIXEIRA, J. P. F. Respostas da soja (Glycine max (L.) Merrill) à aplicação de doses de calcário em latossolo roxo distrófico do cerrado; I. Efeito imediato. In: SEMINÁRIO NACIONAL DE PESQUISA DE SOJA, 2, Brasília, 1981. Anais. Londrina: CNPSo - EMBRAPA, 1981. v.2, p. 742-751. 
MASCARENHAS, H. A. A.; TANAKA, R. T.; GALLO, P. B.; PEREIRA, J. C. V. N. A.; AMBROSANO, G. M. B.; CARMELLO, Q. A. C. Efeito da calagem sobre a produtividade de grãos, óleo e proteína em cultivares precoces de soja. Scientia Agricola, v.53, n.1, p. 164-171, 1996.

McBLAIN, B. A.; BERNARD, R. L. A new gene affecting the time of flowering and maturing in soybeans. Journal of Heredity, v.78, p.160-162, 1987.

MIRANDA, M. C. A. Cultivares de soja para o Estado de São Paulo. In: CÂMARA, G. M. de S.; MARCOS FILHO, J.; OLIVEIRA, E. A. M. de (ed.). SIMPÓSIO SOBRE CULTURA E PRODUTIVIDADE DA SOJA, 1, Piracicaba, 1991. Anais. Piracicaba: FEALQ, 1992. p.109-118.

MIRANDA, M. A. C. Seleção recorrente divergente para peso de sementes e porcentagem de óleo em soja com uso da macho-esterelidade genética. Piracicaba, 1994. 112p. Tese (Doutorado) - Escola Superior de Agricultura "Luiz de Queiroz", Universidade de São Paulo.

MIRANDA, M. C. A. de, MIYASAKA, S.; MASCARENHAS, H. A. A.; ROSSETO, D. Melhoramento da soja no Estado de São Paulo. In: A soja no Brasil Central. Campinas: Fundação Cargill, 1977. p.25-54.

MIRANDA, M. A. C. de, SUASSUNA FILHO, J.; BULISANI, E. A.; MASCARENHAS, H. A. A.; TISSELI FILHO, O.; BRAGA, N. R. Efeito maternal e de genótipo sobre o teor de óleo e tamanho das sementes em sementes $\mathrm{F}_{1}$ de soja In: SEMINÁRIO NACIONAL DE PESQUISA DE SOJA, 3, Campinas, 1984. Anais. Londrina: CNPSo - EMBRAPA, 1984. p. 308-317.

MIYASAKA, S. Contribuição para o melhoramento da soja no Estado de São Paulo. 1958, 48p. Tese (Doutorado) - Escola Superior de Agricultura "Luiz de Queiroz", Universidade de São Paulo.

MIYASAKA, S.; ARAÚJO, P. F. C. Relatório de viagem ao Japão. Campinas, 1973. 30p. (Relatório IAC).

MOHAMED, A. I.; MEBRAHTU, T.; RANGAPPA, M. Nutrient composition and antinutritional factors in selected vegetable soybean (Glycine max [L.] Merrill). Plant Foods for Human Nutrition, v.41, p.89-100, 1991. 
MONTANO-VELASCO, J. C. Análise genética de progênies $F_{3}$ de soja derivadas de cruzamentos em cadeia com ênfase na produção de óleo. Piracicaba, 1994. 115p. Tese (Doutorado) - Escola Superior de Agricultura “Luiz de Queiroz", Universidade de São Paulo.

MOREIRA, M. A.; SEDIYAMA, C. S.; GOMES, J. C.; CHAVES, J. B.; ARAÚJO, E. F.; REZENDE, S. T. Desenvolvimento de cultivares de soja com sementes de melhor qualidade e sabor para alimentação humana. In: BANDEL, G.; PIZZARINIKLEINER, A. A..; AZEVEDO, J. L. (Eds.) SIMPÓSIO INTERNACIONAL NOVOS RUMOS DA GENÉTICA E BIOTECNOLOGIA EM PLANTAS, ANIMAIS E MICRORGANISMOS NA AGROINDÚSTRIA, Piracicaba, 1991. Anais. Piracicaba: Departamento de Genética - ESALQ/USP, 1991. p.57-62.

MORO, G. L.; REIS, M. S.; SEDIYAMA, C. S.; SEDIYAMA, T.; OLIVEIRA, A. B. Correlações entre alguns caracteres agronômicos em soja (Glycine max (L.) Merrill). Revista Ceres, v.39, n.223, p.225-232, 1992.

MOUSAVI, Y.; ADLERCREUTZ, H. Genistein is an effective stimulator of sex hormone-binding globulin production in hepatocarcinoma human liver cancer cells and suppresses proliferation of these cells in culture. Steroids, v.58, p.301-304, 1993.

MUSZYNSKI, A.; JARANOWSKI, J. Interrelations between traits as a basis for estimation of selection value in soybean [Glycine $\max$ (L.) Merrill]. Genetica Polonica, v.24, n.1, p.51-58, 1983.

NAKAGAWA, J.; MACHADO, J. R.; ROSOLEM, C. A. Efeito da densidade de plantio e da época de semeadura na produção e qualidade de sementes de soja. Revista Brasileira de Sementes, v.8, n.3, p.99-112, 1986.

NAKAGAWA, J.; MACHADO, J. R.; ROSOLEM, C. A. Efeito da densidade de plantas no comportamento de cultivares de soja. Científica, v.15, n.1/2, p.23-36, 1987.

NAKAGAWA, J.; ROSOLEM, C. A.; MACHADO, J. R. Efeito da densidade de plantas no comportamento de cultivares de soja, em duas épocas de semeadura. Pesquisa Agropecuária Brasileira, v.23, n.9, p.1003-1014, 1988.

NGUYEN, V. Q. $\quad$ Edamame (vegetable soybean). http://www.rirdc.gov.au/pub/handbook/edamame.html. 
NOGUCHI, A. Recent research and industrial achievement on soybean foods in Japan. In: CONGRESSO BRASILEIRO DE SOJA, Londrina, 1999. Anais. Londrina: CNPSo - EMBRAPA, 1999, p.244-250.

OKUBO, K; IIJIMA, M; KOBAYASH, Y; YOSHIKOSHI, M.; UCHIDA, T.; KUDOU, S. Components responsible for the undesirable taste of soybean seeds. Bioscience and Biotechnology Biochemistry, v.56, p.99-103. 1992.

OMI, N.; AOI, S.; MURATA, K.; EZAWA, K. Evaluating the effect of soybean milk and soybean milk peptide on bone metabolism in the rat model with ovariectomized osteoporosis. Journal of Nutrition Society, v.40, p.201-211, 1994.

ORF, J. H. Breeding soybeans lacking antinutritional factors. In: WORLD SOYBEAN RESEARCH CONFERENCE, 4.; Buenos Aires, 1989. Proceedings. Buenos Aires, Associacion Argentina de la Soja, 1989. p.1091-1100.

PACOVA, B. E. V. Análise genética de progênies segregantes de soja apropriada para o consumo humano. Piracicaba, 1992. 217 p. Tese (Doutorado) - Escola Superior de Agricultura "Luiz de Queiroz", Universidade de São Paulo.

PAKPAENKITVATANA, R.; SAMASUT, R.; TANPHAICHITR, V. The effect of soybean oil intake on lipid status in healthy man. ASA Tech Bulletin, v. HN8, 1989.

PANTALONE, V. R.; BURTON, J. W.; CARTER Jr, T. E. Soybean fibrous root heritability and genotypic correlations with agronomic an seed quality traits. Crop Science, v.36, p.1120-1125, 1996.

PEREIRA, M. G.; SEDIYAMA, T.; SEDIYAMA, C. S.; CASALI, V. W. D.; SILVA, R. F. Eficiência de processos de seleção na obtenção de genótipos de soja agronomicamente superiores. In: SEMINÁRIO NACIONAL DE PESQUISA DE SOJA. Campinas, 1984. Anais Londrina: CNPSo - EMBRAPA, 1984. p.244-250.

PFEIFFER, T. W.; HILDEBRAND, D. F.; TE KRONY, M. D. Agronomic performance of soybean lipoxigenase isolines. Crop Science, v.32, p.357-362, 1992.

PIMENTEL GOMES, F. Análise de grupos de experimentos In: Gomes, F. P. (Ed.) Curso de Estatística Experimental. Piracicaba: Nobel, 1991. 14.ed., cap.8, p168197.

PIPER, C. V.; MORSE, W. J. The Soybean. New York: McGraw Hill, 1923. 310p. 
RACKIS, J. J. Biologically active components. In: SMITH, A. K.; CIRCLE, S. J. Soybeans: Chemistry and Technology. Westport: AVI, 1972. p.158-202.

RACKIS, J. J. Comparison of food value in immature, mature and germinated soybeans. In: TERANISHI, R.; BERRERO-BENITZ, H. (eds.) Quality of fruits and vegetables in North America. Washington: American Chemical Society, 1981. p.183-212.

RACKIS, J. J.; HONIG, D. H.; SESSA, D. J.; STEGGERDA, F. R. Flavor and flatulence factors in soybean protein products. Journal of Agricultural Food Chemistry, v.18, p.977-982, 1970.

RACKIS, J. J.; HONIG, D. H.; SESSA, D. J.; MOSER, H. A. Lipoxigenase and peroxidase activities of soybeans as related to the flavor profile during maturation. Cereal Chemistry, v.49, p.585-597, 1972.

REDDY, P. N.; REDDY, K. N.; RAO, S. K.; SINGH, S. P. Effect of seed size on qualitative and quantitative traits in soybean (Glycine max (L.) Merrill.). Seed Science and Technology, v.17, p.289-295, 1989.

REIS, A. O leite de soja na alimentação de lactantes. Série de Informes Técnicos. Rio de Janeiro: Serviço Especial de Saúde do Ministério da Agricultura, v.5, 1957, 13p.

REIS, B. G. O feijão soja. Rio Grande do Sul: Secretaria da Agricultura. 1956. s.p. (Circular 41).

ROCHA, M. M. Interação genótipos $\mathrm{x}$ locais em linhagens experimentais de soja com diferentes ciclos de maturação. Piracicaba, 1998. 98p. Dissertação (Mestrado) Escola Superior de Agricultura "Luiz de Queiroz", Universidade de São Paulo.

ROCHA, M. M.; VELLO, N. A. interação genótipos e locais para rendimento de grãos de linhagens de soja com diferentes ciclos de maturação. Bragantia, v.58, n.1, p.69$81,1999$.

ROSOLEM, C. A.; SILVÉRIO, J. C. O.; NAKAGAWA, J. Densidade de plantas na cultura da soja. Pesquisa Agropecuária Brasileira, v.18, n.9, p.977-984, 1983.

SAKA, K.; SHIPE, E. R; WALLACE, S. U. Relationship among plant characters in soybean with different seed size. Soybean Genetics Newsletter, v.23, p.225-229, 1996. 
SAKIYAMA, N. S.; SEDIYAMA, T.; SEDIYAMA, C. S.; REIS, M. S. Interação genótipo $\mathrm{x}$ ambiente e seus efeitos na escolha de localidades para avaliação de linhagens de soja (Glycine $\max$ (L.) Merrill). Revista Ceres, v.35, n.201, p.486-493, 1988.

SANCHEZ, A., HORNING, M. C., SHACLICK, G. W., WINGELETH, D. C., HUBBARD, R. W. Changes in levels of cholesterol associated with plasma amino acids in human fed plant proteins Nutrition Report International, v.32, p.10471056, 1985.

SANTOS, A. L. C. Variabilidade entre genótipos de soja (Glycine max (L.) Merrill) nas fases imatura e madura de desenvolvimento. Piracicaba, 1988. $135 \mathrm{p}$. Dissertação (Mestrado) - Escola Superior de Agricultura "Luiz de Queiroz", Universidade de São Paulo.

SANTOS, C. A. F.; REIS, M. S.; SEDIYAMA, C. S.; CRUZ, C. D.; SEDIYAMA, T. Parâmetros genéticos e seleção indireta em progênies $\mathrm{F}_{6}$ de um cruzamento de soja (Glycine max (L.) Merrill). Revista Ceres, v.42, n.240, p.155-166, 1995.

SCHNEEMAN, B. O. Dietary fiber: physiological and chemical methods of analysis and physiological effects. Food Technology, v.40, n.2, p.104, 1986.

SCOTT, A. J., KNOTT, M. A. A cluster method for grouping means in the analysis of variance. Biometrics, v.30, p.507, 1974.

SEDIYAMA, T.; DESTRO, D.; SEDIYAMA, C. S.; TRAGNAGO, J. L.; CARRARO, I. M.; COSTA, A. V. Caracterização de cultivares de soja. Viçosa: Imprensa Universitária da UFV, 1981. 81p. (Boletim n. ${ }^{\circ} 120$ ).

SHANMUNGASUNDARAM, S.; TSOU, T. C. S. Photoperiod and critical duration for flower induction in soybean. Crop Science, v.18, p.598-601, 1978.

SHANMUNGASUNDARAM, S.; CHUNG-RUEY, Y. Screening for immature green soybeans as a vegetable. Soybean Genetícs Newsletter, v.9, p.95-96, 1982.

SHANMUNGASUNDARAM, S.; TSOU, S. C. S.; CHENG, S. H. Vegetable soybeans in the East. In: WORLD SOYBEAN RESEARCH CONFERENCE, 4., Buenos Aires, 1989. Proceedings. Buenos Aires: Associación Argentina de la Soja, 1989. p.19791986. 
SHARMA, O. P.; ADLERCREUTZ, H.; STRANDBERG, J. D.; ZIRKIN, B. R.; COFFEY, D. S; EWING, L. L. Soy of dietary source plays a preventive role against pathogenesis of prostitis in rats. Journal of Steroid Biochemistry and Molecular Biology, v.43, p.557-564, 1982.

SHORTER, R.; BYTH, D. E.; MUNGOMERY, V. E. Estimates of selection parameters associated with protein and oil content on soybean seeds (Glycine max (L.) Merrill). Australian Journal of Agricultural Research, v.28, p.211-222, 1976.

SIMPSON Jr, A. M.; WILCOX, J. R. Genetic and phenotypic associations of agronomic characteristics in four high soybean populations. Crop Science, v.23, p.1077-1081, 1983.

SINCLAIR, T. R; HINSON, K. Soybean flowering in response to the long-juvenile trait. Crop Science, v.32, p.1242-1248, 1992.

SINGH, J. L.; TRIPATHI, S. K.; NEGI, P. S. Note on the effect of seed size on germination, growth and yield of soybean (Glycine max (L.) Merrill). Indian Journal of Agricultural Science, v.42, p.83-86, 1972.

SINGH, M. P.; ANDERSON, J. C. Inheritance of earliness of maturity in soybeans, Glycine max (L.) Merrill. Agronomy Journal, v.41, p.477-483, 1949.

SINGH, T. P.; SINGH, K. B.; BRAR, J. S. Diallel analysis in soybeans. Indian Journal of Genetics and Plant Breeding, v.34, n.3, p.427-432, 1974.

SIRTORI, C. R.; GATTI E.; MANTERO. O,; CONTI, F.; AGRADI, E.; TREMOLI, E.; SIRTORI, M.; FRATERRIGO, L.; TAVAZZI, L.; KRITCHEVSKY, D. Clinical experience with the soybean protein diet in the treatment of hypercholesterolemia. American Journal of Clinical Nutrition, p.32, p.1645-4658, 1979.

SMITH, A. K.; CIRCLE, S. J. Chemical composition of the seed. In: SMITH, A. K.; CIRCLE, S. J. Soybeans: Chemistry and Technology. Wesport: AVI, 1972, p.339-388.

SMITH, A. K.; WATANABE, T.; HASH, A. M. Tofu from japanese and United State soybeans. Food Technology, v.14, n.7, p.332-336. 1960.

SMITH, J. M.; VAN DUYNE, F. O . Other soybeans products. In: Markley (ed.) Soybeans and soybean products, v.2. New York: Interscience, 1951. p.1055-1078. 
SMITH, T. J.; CAMPER, H. M. Effect of seed size on soybean performance. Agronomy Journal, p.67, p.681-684, 1975.

SOLDINI, D. O. Interação genótipos x locais e correlações entre caracteres com ênfase na produtividade de óleo de soja. Piracicaba, 1993. 136p. Dissertação (Mestrado) - Escola Superior de Agricultura "Luiz de Queiroz", Universidade de São Paulo.

SZCZESNIAK, A. S.; KAHN, E. L. Consumer awareness of and attitudes to food texture. I: Adults. Journal of Texture Studies, v.2, p.280-297, 1971.

TAIRA, H. Quality of soybeans for processed foods in Japan. Japan Agricultural Research Quarterly, v.24, n.3, p.224-230, 1990.

TANAKA, R. T.; MASCARENHAS, H. A. A.; D`ÀRCE, M. A. B. R.; GALLO, P. B. Concentração e produtividade de óleo e proteína de soja em função da adubação potássica e da calagem. Pesquisa Agropecuária Brasileira, v.30, n.4, p.463-469, 1995

TEIXEIRA, J. P. F.; MASCARENHAS, H. A. A.; BATAGLIA, O. C. Efeito de cultivares, tipos de solo e práticas culturais sobre a composição quírnica de sementes de soja [Glycine max (L.) Merrill). In: SEMINÁRIO NACIONAL DE PESQUISA DE SOJA, 1, Londrina, 1978. Anais. Londrina: CNPSo - EMBRAPA, 1979a. p.1116.

TEIXEIRA, J. P. F.; MASCARENHAS, H. A. A.; MIRANDA, M. A. C.; BRAGA, N. R. Efeito de localidades, adubação e anos consecutivos de plantio sobre o teor de proteínas em sementes de soja cv. "Santa Rosa". Científica, v,7, n.3.; p.343-346, 1979b.

TEIXEIRA, J. P. F.; RAMOS, M. T. B.; MIRANDA, M. A. C. de, MASCARENHAS, H. A. A. Relação entre os principais constituintes químicos do grão de soja. In: SEMINÁRIO NACIONAL DE PESQUISA DE SOJA, 3, Campinas, 1984. Anais. Londrina: CNPSo - EMBRAPA, 1984.

THORNE, J. C.; FEHR, W.R. Incorporation of high-protein, exotic germoplasm into soybean population by 2 - and 3 - way crosses. Crop Science, v.10, p.652-655, 1970. 
TINIUS, C. N.; BURTON, J. W.; CARTER Jr, T. E. Recurrent selection for seed size in soybean. III. Indirect effects on seed composition. Crop Science, v.33, n.5, p.959962, 1993.

TOLEDO, J. F. F.; KIIHL, R. A. S. Análise do modelo genético envolvido no controle de dia para florescimento em soja. Pesquisa Agropecuária Brasileira, v.17, p.2327, 1982a.

TOLEDO, J. F. F.; KIIHL, R. A. S. Métodos de análise dialélica no modelo genético no controle das características dias para floração e número de folhas trifolioladas em soja. Pesquisa Agropecuária Brasileira, v.17, p.745-755, $1982 \mathrm{~b}$.

TSAI, A. C.; MOTT, E. L.; OWEN, G. M.; BENNICK, M. R.; LO, G. S.; STEINKE, F. S. Effect of soy polysaccharide on gastrointestinal function, nutrient balance, steroid excretion, glucose tolerance, serum lipids and other parameters in humans. American Journal of Clinical Nutrition, v.38, p.504-51 1, 1983.

UNIVERSIDADE DE SÃO PAULO. Centro de Informática Aplicada à Agricultura. Programa SAS; programa de análise estatística (software). Piracicaba: CIAGRI/USP. 2000

VAN RAAIJ, J. M. A.; KATAN, M. B.; WEST, C. E.; HAUTVAST, J. G. A. J. Influence of diets containing casein, soy isolate, and soy concentrate on serum cholesterol and lipoproteins in middle-aged volunteers. American Journal of Clinical Nutrition, v35, p.925-934, 1982.

VELLO, N. A., HIROMOTO, D. M., AZEVEDO FILHO, A. J. B. V. Coefficient of parentage and breeding of Brazilian soybean germoplasm. Revista Brasileira de Genética, v.11, p.679-697, 1988.

VELLO, N. A. Métodos de melhoramento de soja. In: SIMPÓSIO SOBRE A CULTURA E PRODUTIVIDADE DA SOJA, 1991. Piracicaba: Anais da FEALQ, Piracicaba, 1992a, p.41-59.

VELLO, N. A. Ampliação da base genética do germoplasma e melhoramento da soja na ESALQ - USP. In: SIMPÓSIO SOBRE A CULTURA E PRODUTIVIDADE DA SOJA, 1991. Piracicaba: Anais da FEALQ, Piracicaba, 1992b, p.60-81.

VELLO, N. A.; FEHR, W. R.; BAHRENFUS, J. A. genetic variability and agronomic perfomance of soybean populations develop from plant introduction. Crop Science, v.24, p.511-514, 1984. 
VENCOVSKY, R. Componentes da variação fenotípica: Análise em vários ambientes. In: VENCOVSKY, R. \& BARRIGA, P. (Ed.) Genética Biométrica no Fitomelhoramento. Ribeirão Preto: Sociedade Brasileira de Genética, 1992a. cap. 4, p. 233-333.

VENCOVSKY, R Associação entre caracteres. In: VENCOVSKY, R.; BARRIGA, P. (Ed.) Genética Biométrica no Fitomelhoramento. Ribeirão Preto: Sociedade Brasileira de Genética, 1992b. cap. 5, p. 335-434.

VERNETTI, F. J., GASTAL, M. F. C., ZONTA, E. P. Estabilidade fenotípica de cultivares de soja no sudeste do Rio Grande do Sul. Pesquisa Agropecuária Brasileira, v.25, n.11, p.1593-1602, 1990.

WANG, H. L.; MUSTAKAS, G. C.; WOLF, W. J.; WANG, L. C.; HESSELTINE, C. W.; BAGLEY, E. B. Soybeans as human food - unprocessed and simply processed. U.S. Department of Agriculture: Utilization Research Report n. ${ }^{\circ}$ 5. 1979. $54 \mathrm{p}$.

WANG, L. H.; SWAIN, E. W.; KWOLLER, W. F. Effect of soybean varieties on the yield and quality of tofu. Cereal Chemistry, v.60, n.3, p.245-248. 1983.

WATANABE, T.; KISHI, A. The book of soybeans. Tokyo: Japan Publications Inc.; 1984. 190p.

WEAVER, D. B.; WILCOX, J. R. Heritabilities, gains from selection, and genetic correlations for characteristics of soybean grown in two row spacing. Crop Science, v.22, p.625-629, 1982.

WEBER, C. R.; MOOTHY, B. R. Heritable and nonheritable relationship and variability of oil content and agronomic characters in the $F_{2}$ generation of soybean crosses. Agronomy Journal, v.44, p.202-209, 1952.

WILCOX, J. R. Breeding soybeans for improved oil quantity and quality. In: World Soybean Research Conference, 3, Ames, 1985. Proceedings. Boulder: Westview Press, 1985. p.380-386.

YEE, Y. B. The nutritional role of soy in health and disease prevention: a review. http://www.pacweb.net.sg/asa/technica//hn23-1994.html.

YEE, Y. B. Update on the health benefits of soy fiber. http://www.pacweb.net.sg/asa/technical/hn26-1994.html 
YOKOMIZO, G. K. Desempenho e variabilidade de topocruzamentos $\mathrm{F}_{5: 4}$ tipo alimento x tipo grão em soja. Piracicaba, 1994. 121p. Dissertação (Mestrado) - Escola Superior de Agricultura "Luiz de Queiroz", Universidade de São Paulo.

YOKOMIZO, G. K. Interação genótipo $\mathrm{x}$ ambientes em topocruzamentos de soja tipo alimento com tipo grão. Piracicaba, 1999. 170p. Tese (Doutorado) - Escola Superior de Agricultura "Luiz de Queiroz", Universidade de São Paulo.

YOKOMIZO, G. K., VELLO, N. A. Use of pod width as visual score in substitution of one hundred seed weight on vegetable soybean. Soybean Genetics Newsletter, v.25, p.21-22, 1998.

YUYAMA, K. Ensaio de épocas de plantio sobre várias características agronômicas na cultura da soja (Glycine max (L.) Merrill), variedades "Júpiter", 'Prata", "Oriente" e 'Pelicano", em Aripuanã-MT. Acta Amazonica, v.9, n.3, p.419-436, 1979.

ZIMBACK, L. E. D. Cruzamentos em cadeia entre genótipos adaptados e exóticos de soja com ênfase na produção de óleo. Piracicaba, 1992. 178p. Tese (Doutorado) Escola Superior de Agricultura "Luiz de Queiroz", Universidade de São Paulo. 


\section{TABELAS ${ }^{1}$}

'Obs.: as Tabelas 1 a 4 contêm informações que não foram obtidas nesta pesquisa e estão distribuídas no capítulo revisão Bibliográfica. 
Tabela 5. Genealogias das progênies e identificação das testemunhas. Soja: Piracicaba, 1998/1998.

\begin{tabular}{|c|c|c|c|c|c|}
\hline \multirow{2}{*}{$\frac{\text { Progênie }}{1}$} & \multicolumn{2}{|l|}{ N. ${ }^{\circ}$ USP } & \multicolumn{3}{|c|}{ Genealogias } \\
\hline & USP98-06001 & & PI 229.320 & $\mathbf{x}$ & Doko \\
\hline 2 & USP98-06002 & & PI 80.441 & $\mathbf{x}$ & Doko \\
\hline 3 & USP98-06003 & & $\left(\mathrm{TK} \# 5\right.$ x Unknown $\left.\mathrm{F}_{7}\right)$ & $\mathbf{x}$ & Doko \\
\hline 4 & USP98-06004 & & $\left(\mathrm{TK} \# 5\right.$ x Unknown $\left.\mathrm{F}_{7}\right)$ & $\mathbf{x}$ & Doko \\
\hline 5 & USP98-06005 & & $\left(\mathrm{TN} \# 4 \times\right.$ xI $\left.230.970 \mathrm{~F}_{7-4}\right)$ & $\mathbf{x}$ & Doko \\
\hline 6 & USP98-06007 & & $\left(\mathrm{KS} 473 \times \mathrm{SJ} 2-\mathrm{F}_{7}\right)$ & $\mathbf{x}$ & Doko \\
\hline 7 & USP98-06008 & & 64-64 x KS 473 & $\mathbf{x}$ & Doko \\
\hline 8 & USP98-06009 & & TMV & $\mathbf{x}$ & Doko \\
\hline 9 & USP98-06010 & & PI 230.977 & $\mathbf{x}$ & Doko \\
\hline 10 & USP98-06011 & & Araçatuba & $\mathbf{x}$ & Doko \\
\hline 11 & USP98-06012 & & Late Giant & $\mathbf{x}$ & Doko \\
\hline 12 & USP98-06013 & & Late Giant & $\mathbf{x}$ & Doko \\
\hline 13 & USP98-06014 & & Late Giant & $\mathbf{x}$ & Doko \\
\hline 14 & USP98-06015 & & Late Giant & $\mathbf{x}$ & Doko \\
\hline 15 & USP98-06016 & & Late Giant & $\mathbf{x}$ & Doko \\
\hline 16 & USP98-06017 & & Late Giant & $\mathbf{x}$ & Doko \\
\hline 17 & USP98-06018 & & Late Giant & $\mathbf{x}$ & Doko \\
\hline 18 & USP98-06019 & & Japão 1 & $\mathbf{x}$ & Doko \\
\hline 19 & USP98-06020 & & Japão 1 & $\mathbf{x}$ & Doko \\
\hline 20 & USP98-06021 & & Japão 2 & $\mathbf{x}$ & Doko \\
\hline 21 & USP98-06022 & & Yamagataken & $\mathbf{x}$ & Doko \\
\hline 22 & USP98-06023 & & Aliança Preta & $\mathbf{x}$ & Doko \\
\hline 23 & USP98-06024 & & Aliança Preta & $\mathbf{x}$ & Doko \\
\hline 24 & USP98-06025 & & Aliança Preta & $\mathbf{x}$ & Doko \\
\hline 25 & USP98-06026 & & Aliança Preta & $\mathbf{x}$ & Doko \\
\hline 26 & USP98-06027 & & IAC PL-1 & $\mathbf{x}$ & FT-2 \\
\hline 27 & USP98-06028 & & FC $31-665$ & $\mathbf{x}$ & Doko \\
\hline 28 & USP98-06029 & & Majos & $\mathbf{x}$ & Doko \\
\hline 29 & USP98-06030 & & Majos & $\mathbf{x}$ & Doko \\
\hline 30 & USP98-06031 & & PI 165.672 & $\mathbf{x}$ & Doko \\
\hline 31 & USP98-06032 & & Tadacha & $\mathbf{x}$ & Doko \\
\hline 32 & USP98-06033 & & PI 229.320 & $x$ & Doko \\
\hline 33 & USP98-06034 & & PI 229.320 & $\mathbf{x}$ & Doko \\
\hline \multirow[t]{4}{*}{ Testem } & & $\mathrm{T} 1$ & \multicolumn{3}{|c|}{ Céu Azul } \\
\hline & & $\mathrm{T} 2$ & \multicolumn{3}{|c|}{ Nimame } \\
\hline & & T3 & \multicolumn{3}{|c|}{ IAC PL-1 } \\
\hline & & $\mathrm{T} 4$ & \multicolumn{3}{|c|}{ Tamba } \\
\hline
\end{tabular}


旁
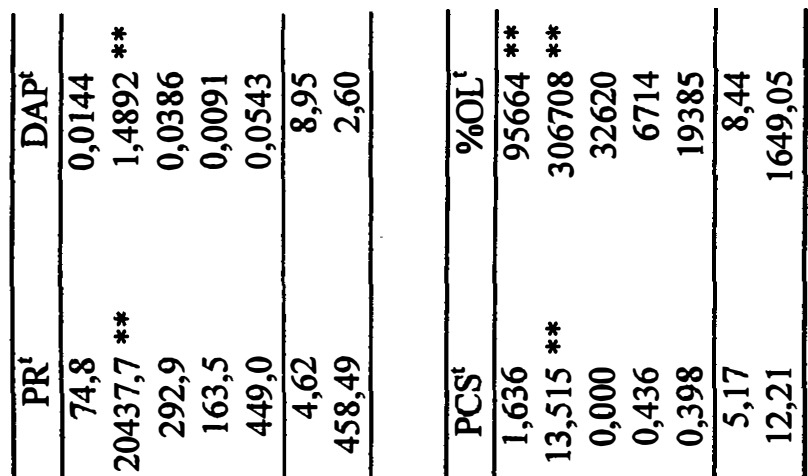

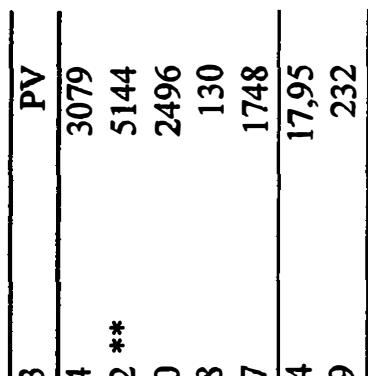

$\infty$

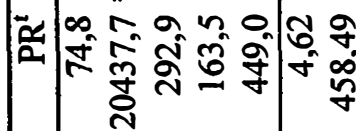

带

ช্

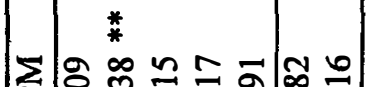

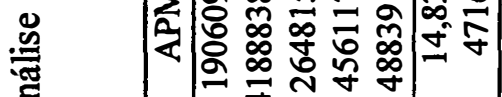

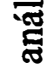

ซึ

.

ช్ำ

魚

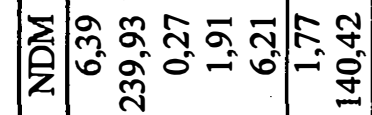

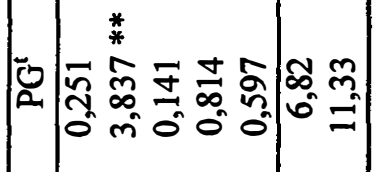

mष

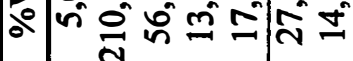

क

(1)

$\stackrel{0}{0}$

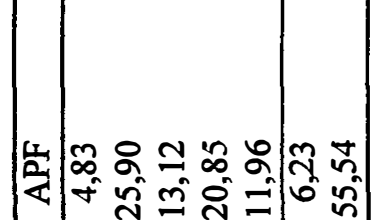

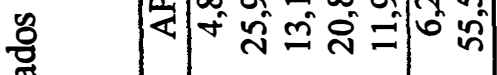

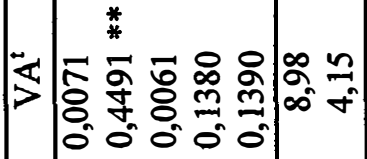

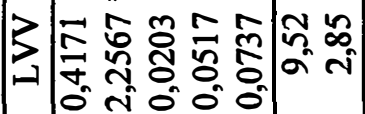

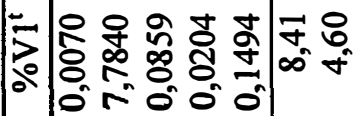

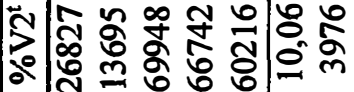
저응

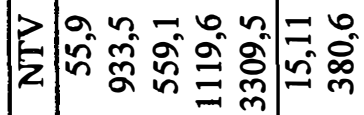

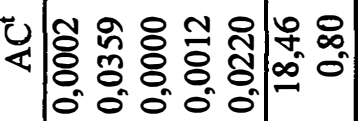

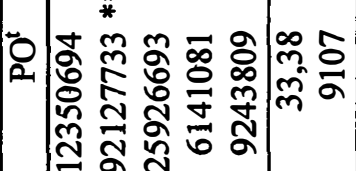

突

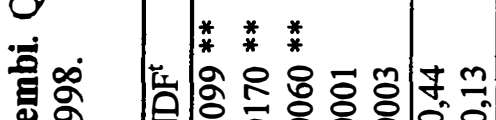

乙 잉 8 0 응

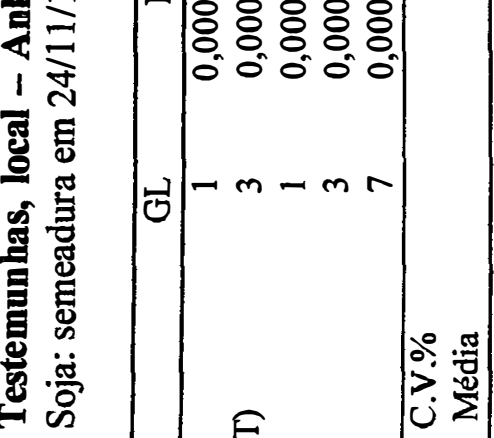

它

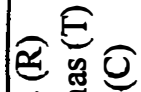

ชิ

$0-m-m n$

进

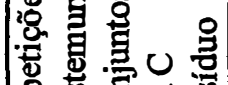

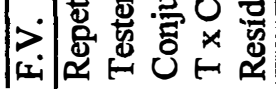

.

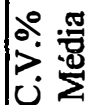

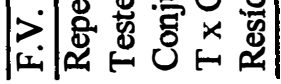

ลี

\&

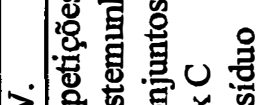

它|

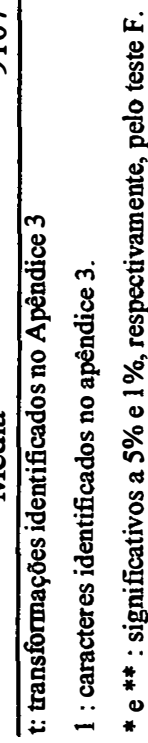


薷

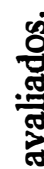

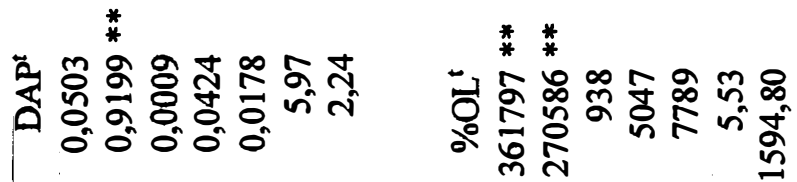

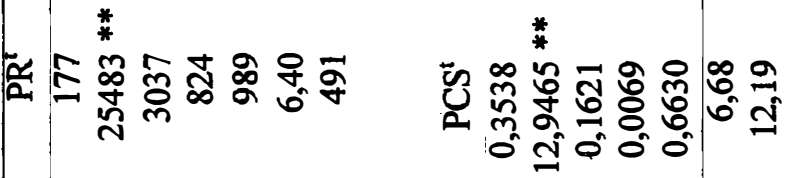

o

爱

8

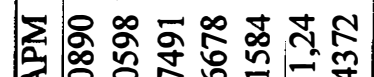

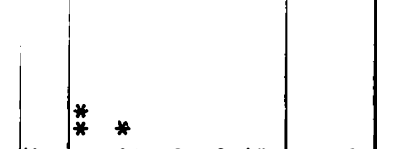

$m=\cong 9$

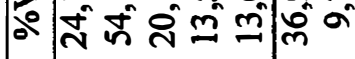

采

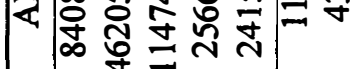

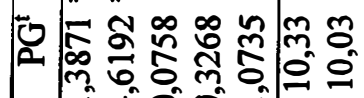

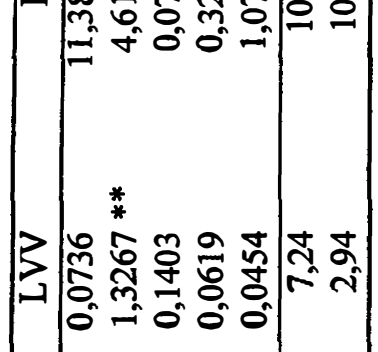

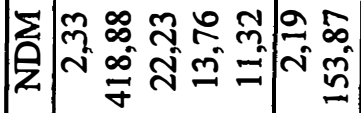

స్

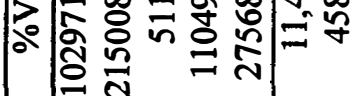

.

ใृ้

.

0

:

岕

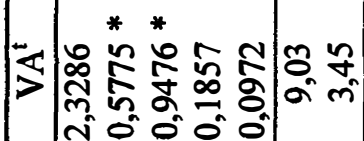

दो

宽

吾

母.

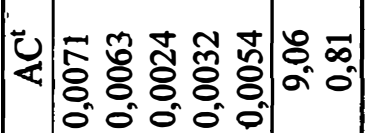

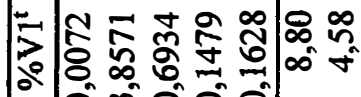

四

응

$1 \equiv$

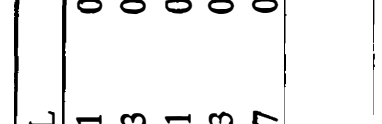

क्ष

总焉

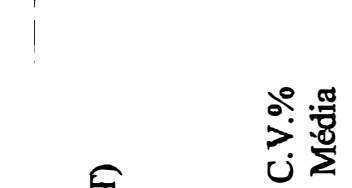

ชู

点

ฉิย

$\rightarrow-m-m r$

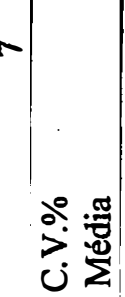

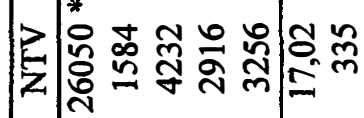
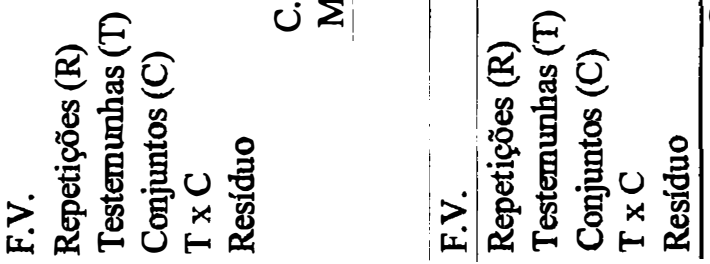

$0-m-m-$ 


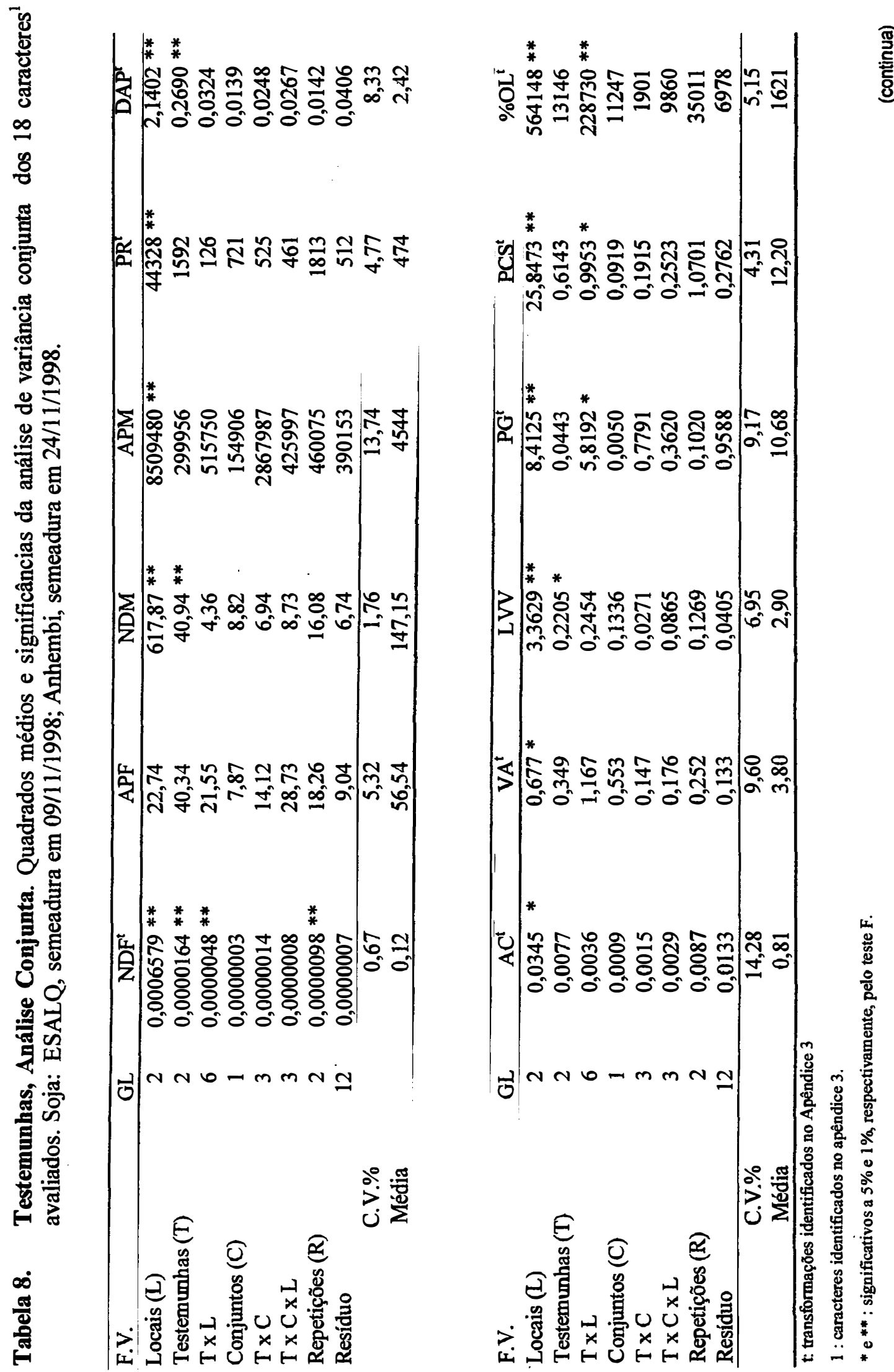




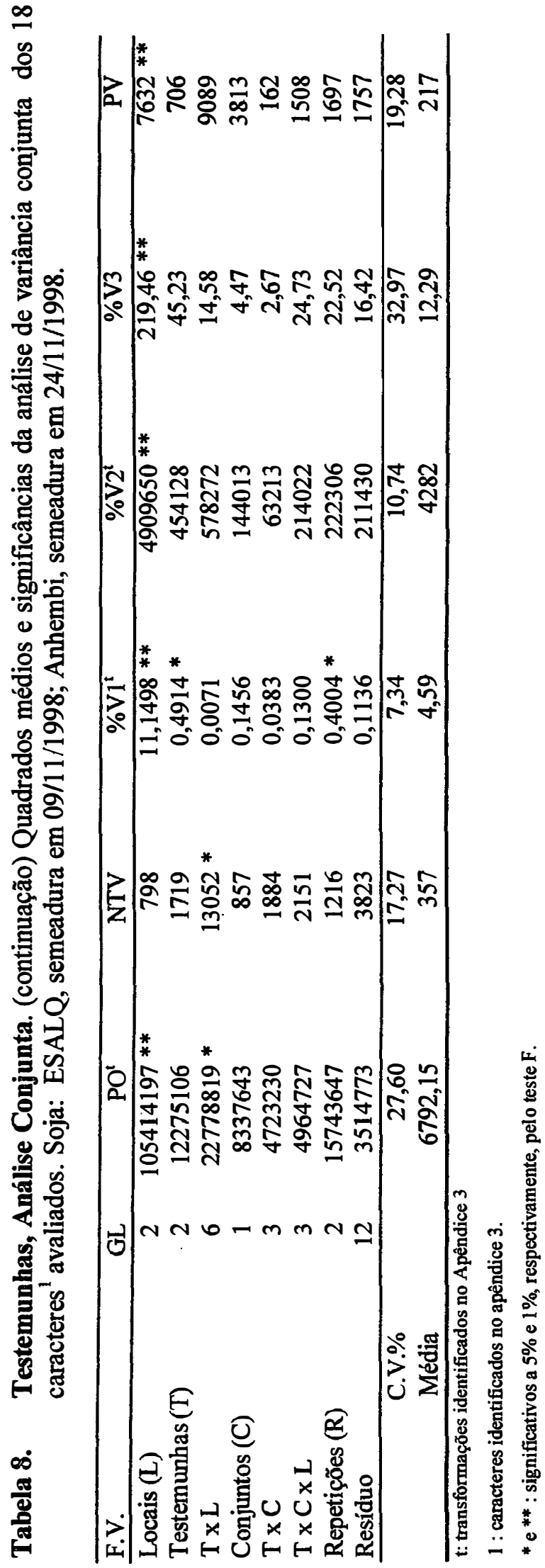




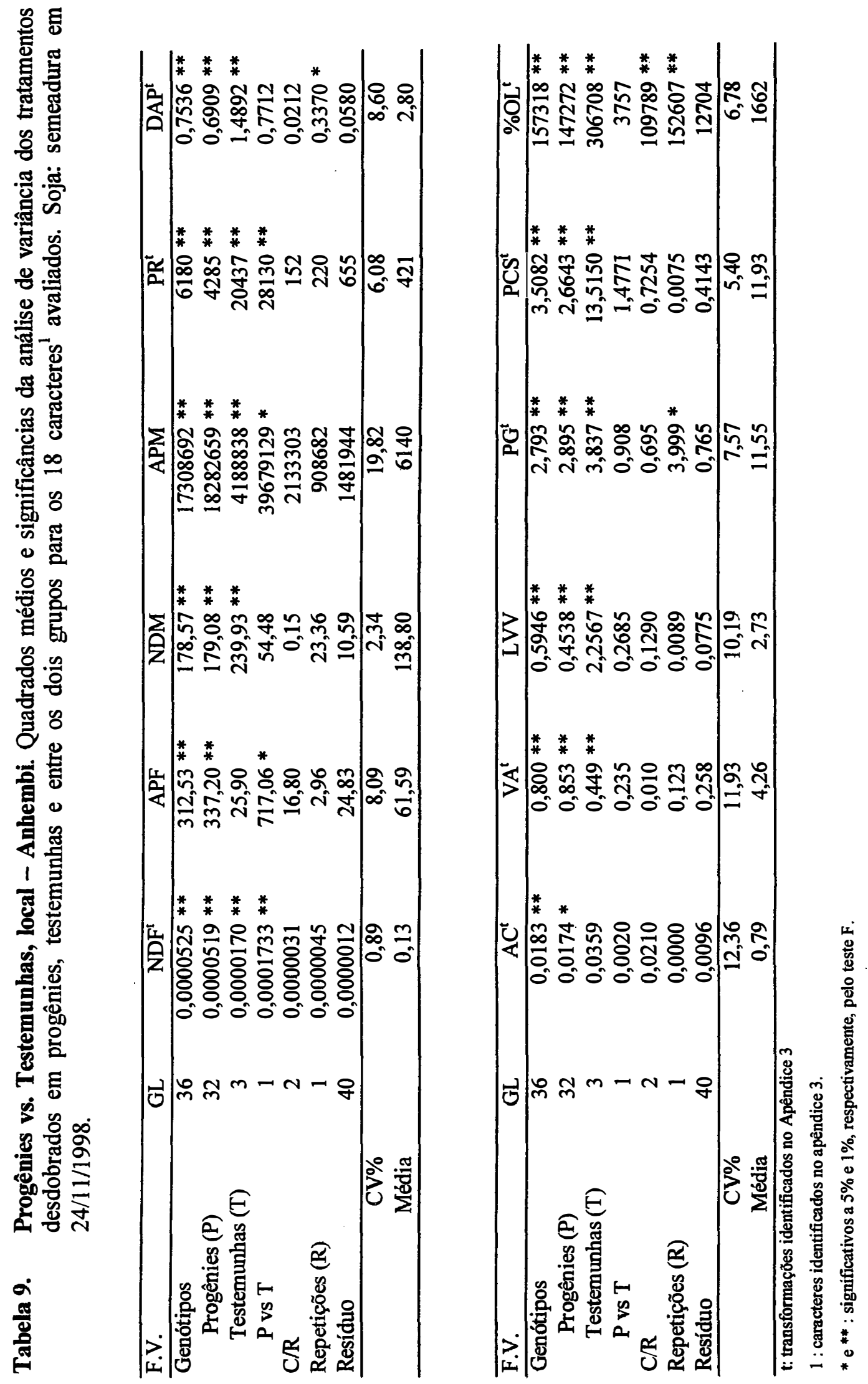




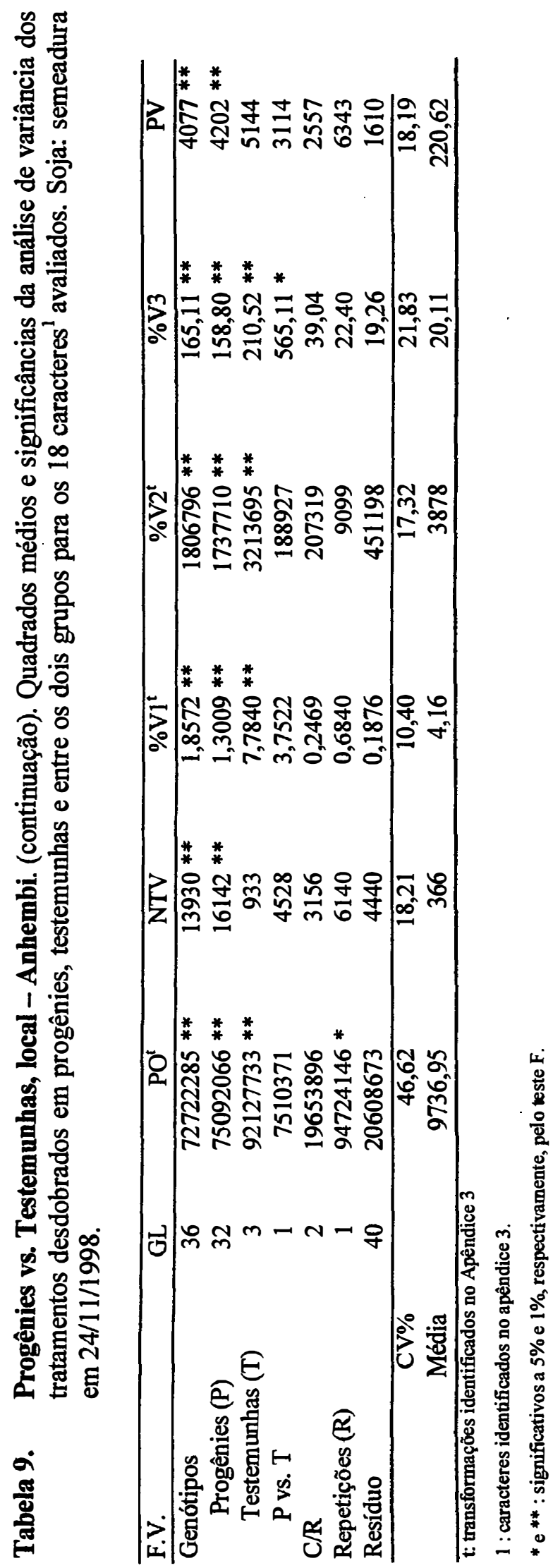




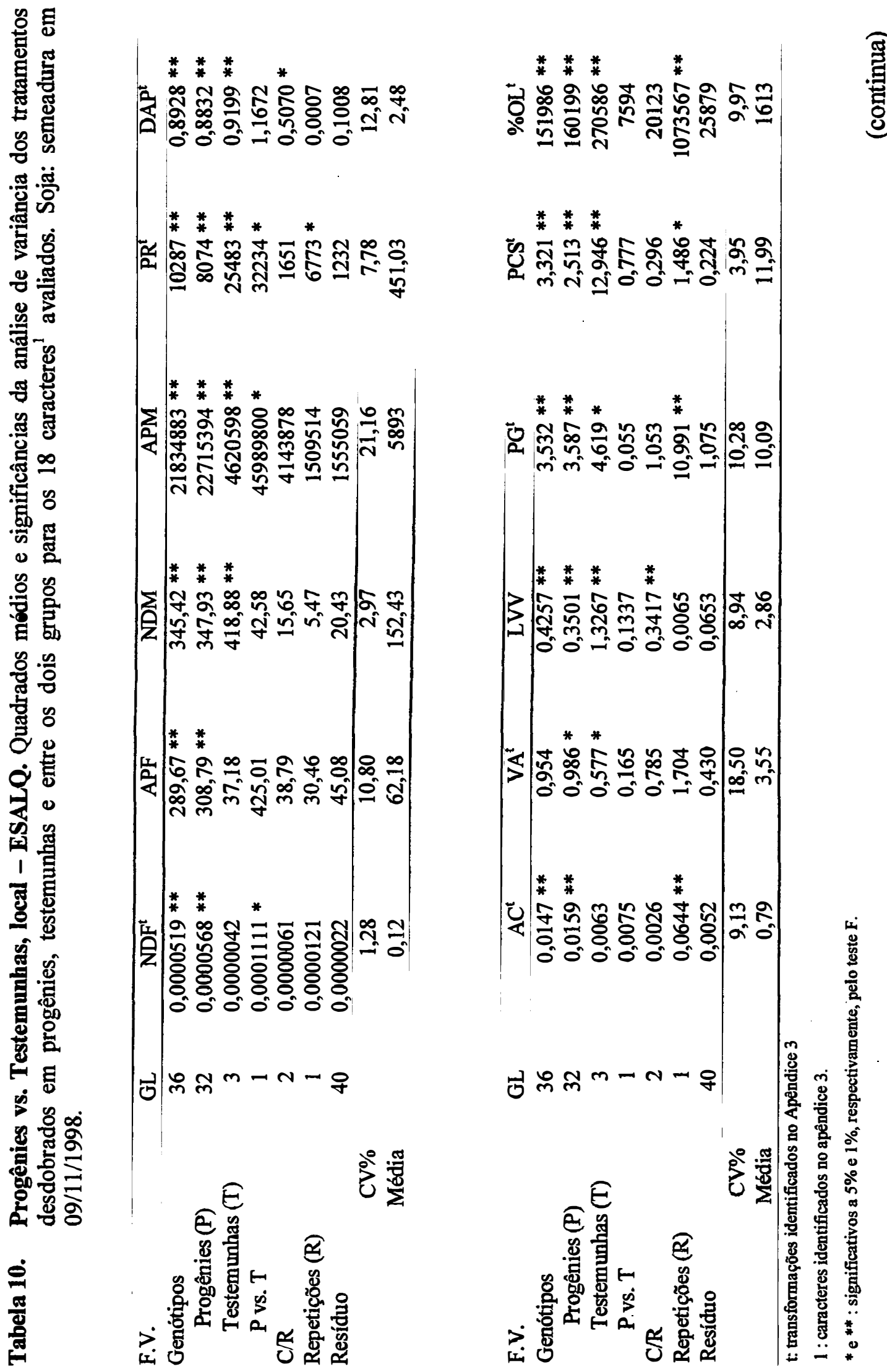




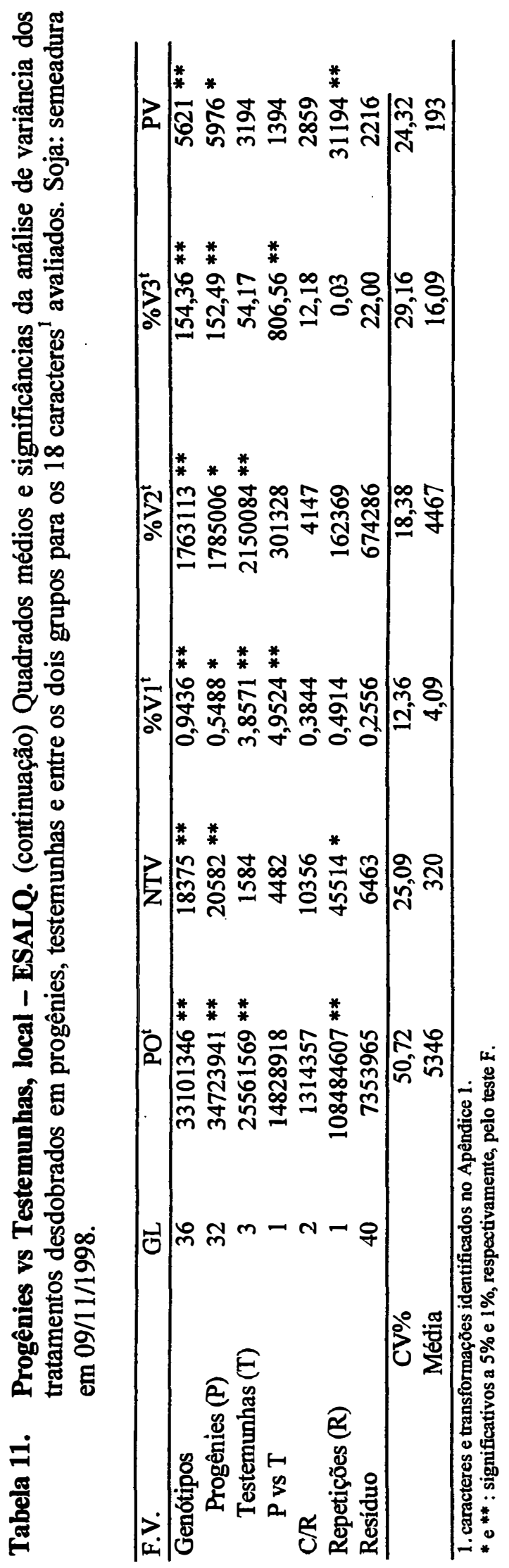




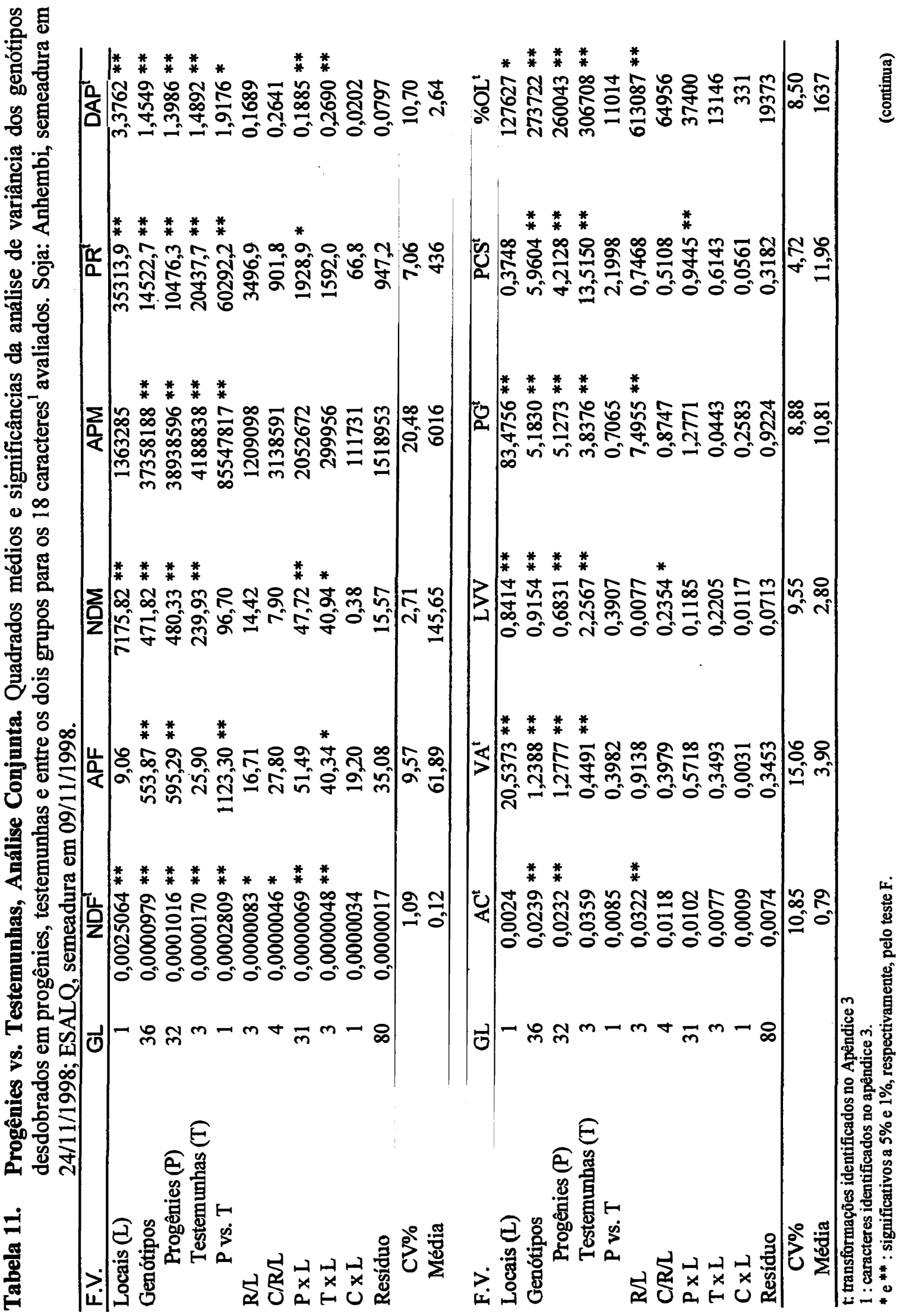




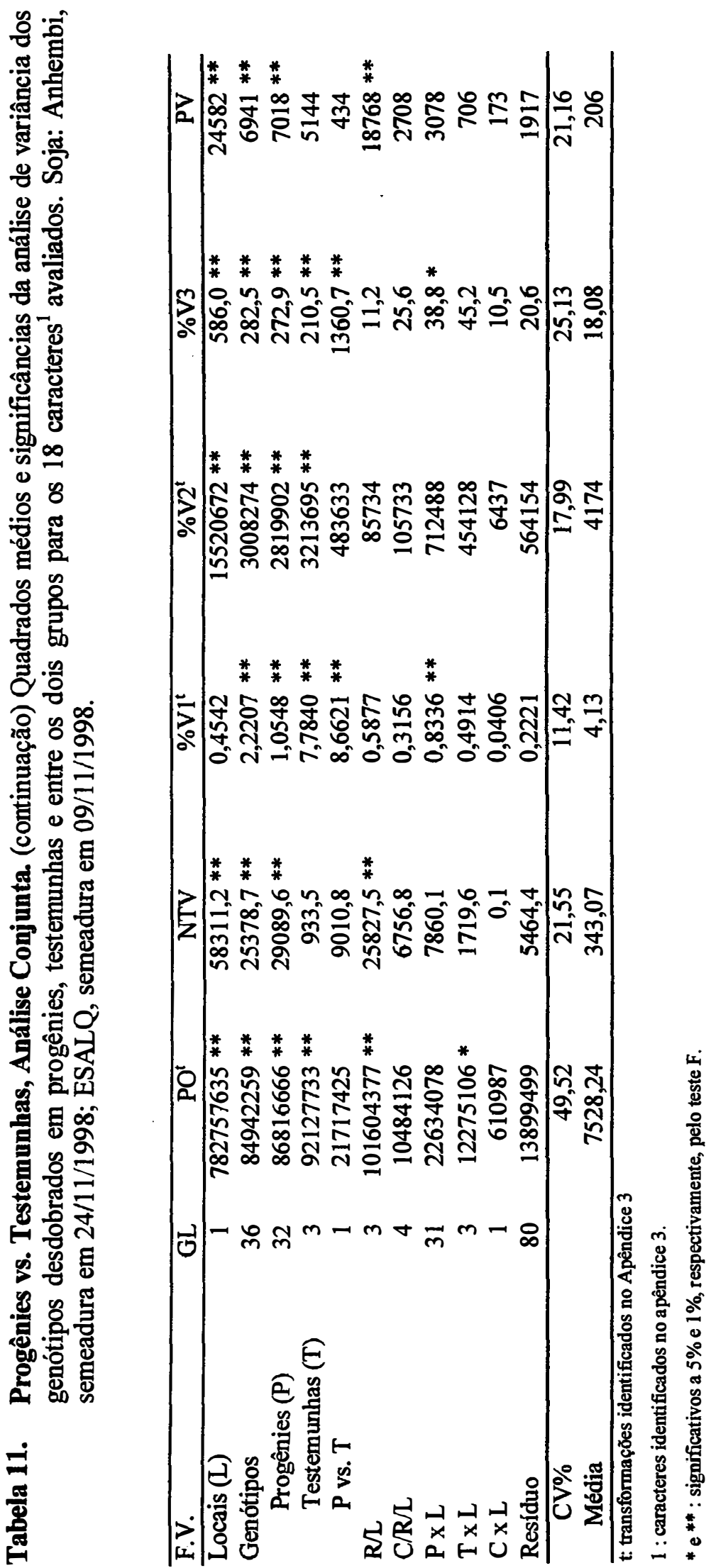




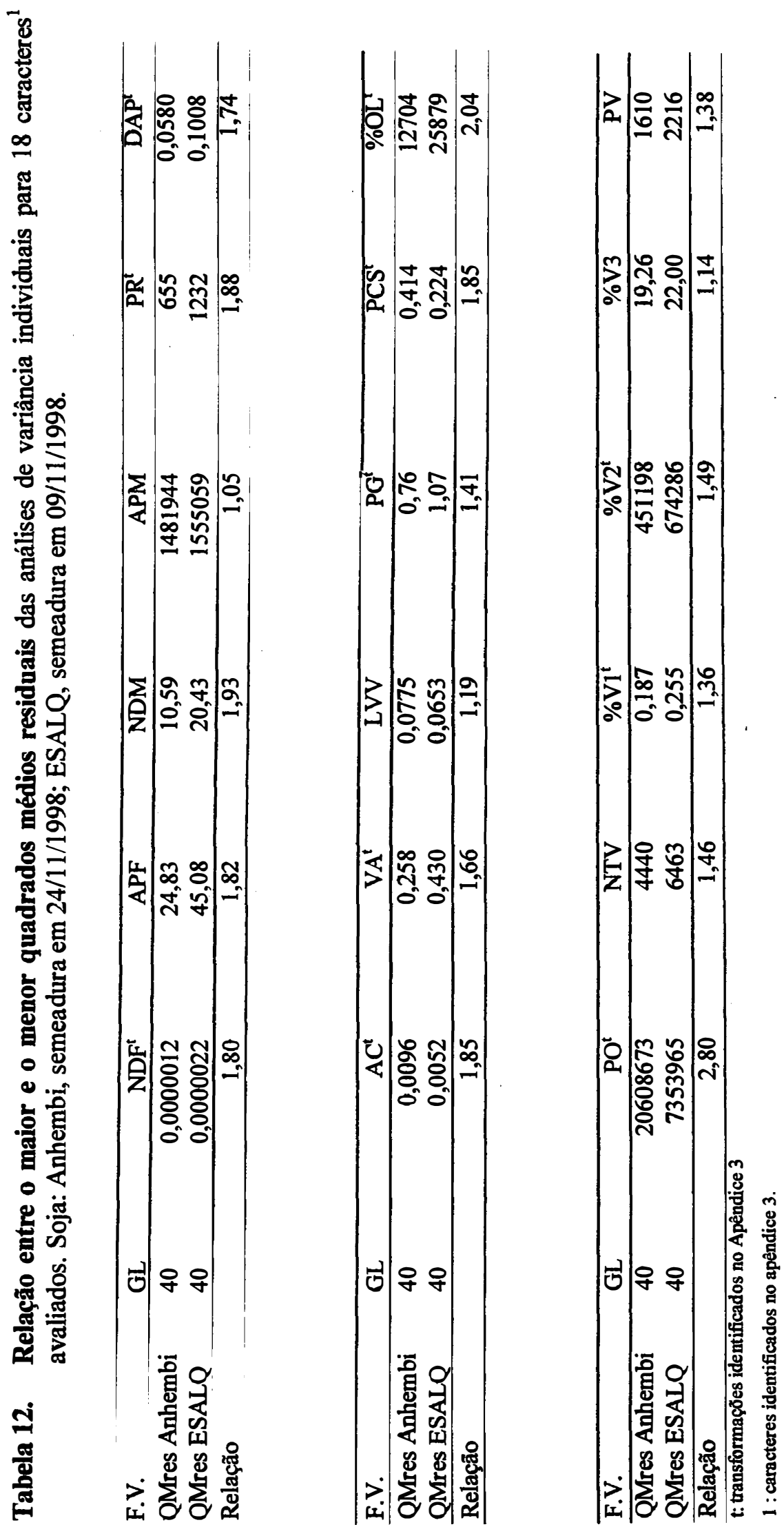




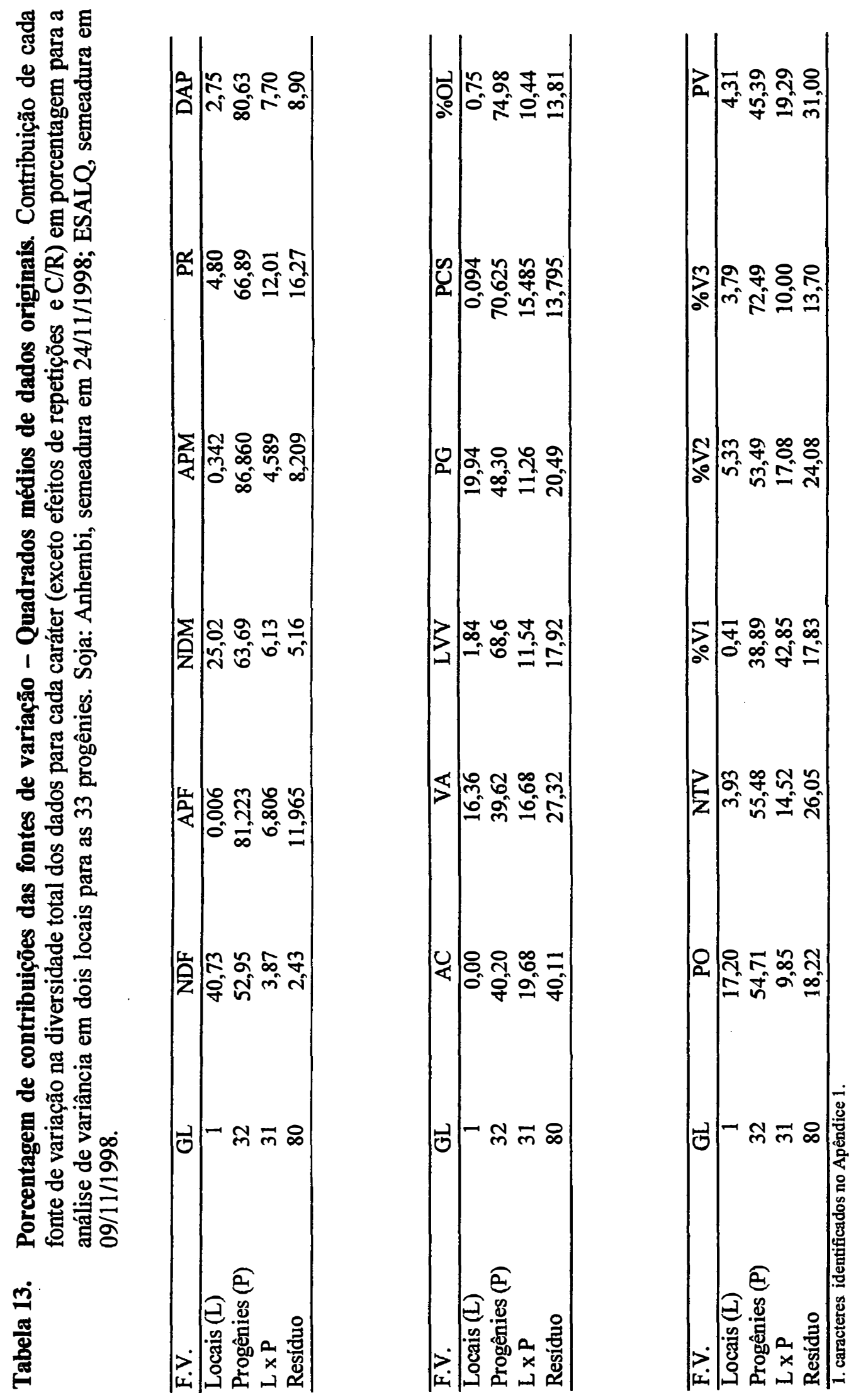




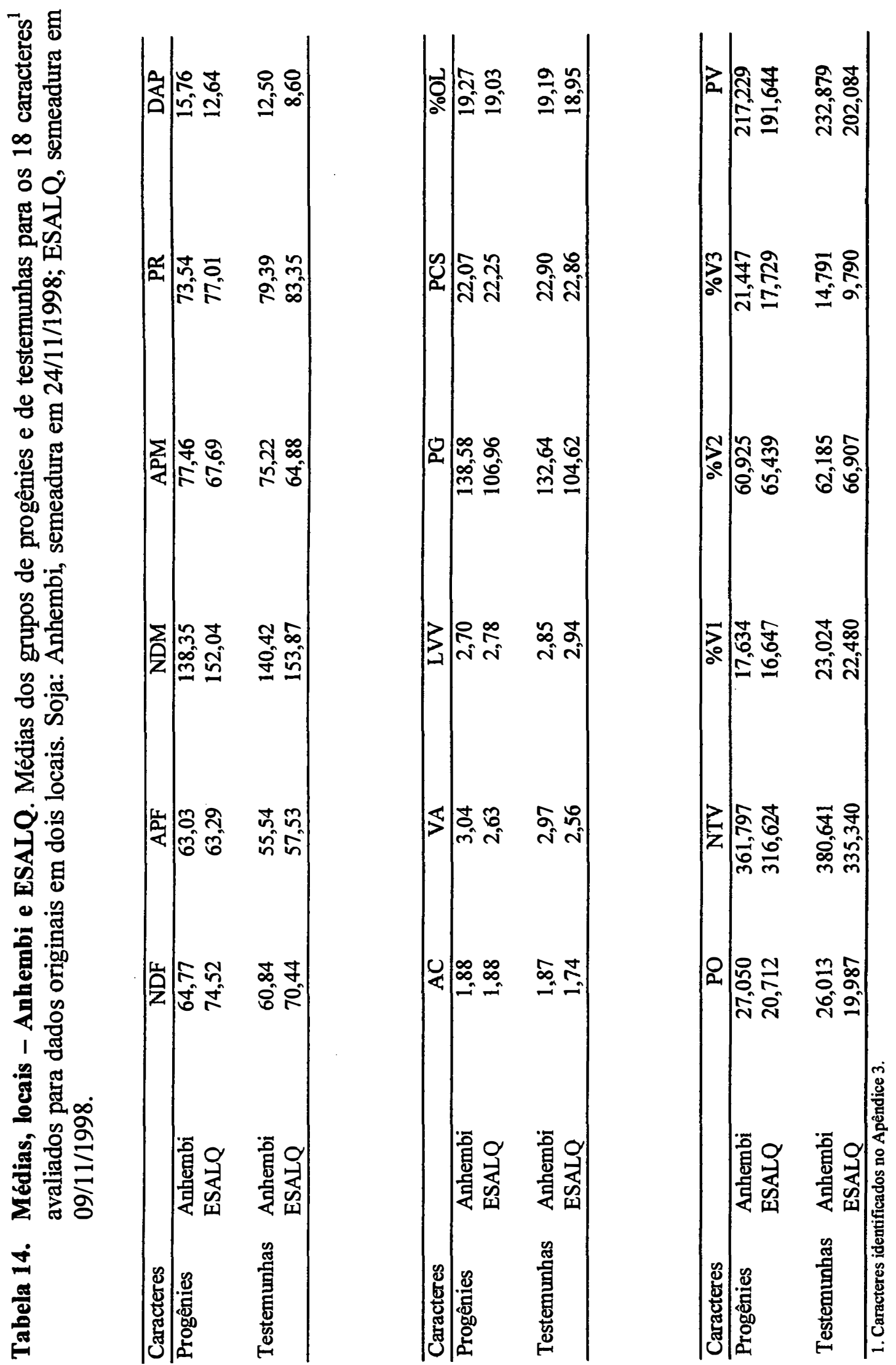


Tabela 15. Médias e Desvios Padrões - Conjunta para dados originais. Médias (m) e desvios padrões (s) das 33 progênies ${ }^{1}$ e das testemunhas para os 18 caracteres $^{2}$ avaliados para dados originais nos dois locais. Soja: Anhembi, semeadura em 24/11/1998; ESALQ, semeadura 09/11/1998.

\begin{tabular}{|c|c|c|c|c|c|c|}
\hline \multirow[t]{2}{*}{ Caracteres } & \multicolumn{2}{|c|}{$\mathrm{NDF}$} & \multicolumn{2}{|c|}{ APF } & \multicolumn{2}{|c|}{ NDM } \\
\hline & $\mathbf{m}$ & $\mathbf{s}$ & $\mathbf{m}$ & $\mathbf{s}$ & $\mathbf{m}$ & $\mathbf{s}$ \\
\hline \multicolumn{7}{|l|}{ Testemunhas } \\
\hline Céu Azul & 66,29 & 5,042 & 55,44 & 3,414 & 144,43 & 7,173 \\
\hline IAC PL-1 & 67,28 & 5,006 & 54,79 & 4,649 & 148,58 & 4,754 \\
\hline Tamba & 63,96 & 6,299 & 58,23 & 5,299 & 158,31 & 10,897 \\
\hline Nimame & 65,05 & 5,045 & 57,71 & 3,306 & 137,26 & 7,754 \\
\hline Médias & 65,65 & 5,348 & 56,54 & 4,167 & 147,15 & 7,645 \\
\hline \multicolumn{7}{|l|}{ Progênies } \\
\hline 1 & 71,39 & 6,020 & 65,80 & 3,040 & 149,29 & 7,645 \\
\hline 2 & 69,47 & 5,359 & 52,16 & 5,329 & 144,52 & 8,136 \\
\hline 3 & 68,64 & 8,848 & 66,52 & 4,977 & 136,83 & 14,044 \\
\hline 4 & 68,44 & 4,446 & 72,75 & 7,425 & 154,69 & 13,845 \\
\hline 5 & 75,63 & 7,386 & 72,04 & 7,710 & 157,92 & 11,288 \\
\hline 6 & 75,82 & 6,578 & 92,83 & 10,013 & 156,35 & 9,643 \\
\hline 7 & 73,75 & 7,630 & 66,78 & 7,151 & 154,42 & 13,359 \\
\hline 8 & 68,14 & 6,395 & 61,58 & 6,893 & 151,13 & 7,800 \\
\hline 9 & 57,03 & 3,682 & 40,11 & 2,218 & 123,98 & 6,775 \\
\hline 10 & 72,08 & 3,928 & 66,16 & 8,488 & 159,88 & 11,502 \\
\hline 11 & 60,75 & 3,182 & 60,50 & 15,548 & 131,50 & 6,874 \\
\hline 12 & 73,65 & 7,165 & 70,77 & 10,332 & 139,05 & 7,685 \\
\hline 13 & 75,10 & 9,758 & 53,87 & 4,997 & 148,27 & 12,822 \\
\hline 14 & 66,55 & 5,641 & 60,11 & 2,922 & 125,67 & 9,394 \\
\hline 15 & 58,64 & 2,847 & 57,05 & 3,270 & 129,41 & 0,646 \\
\hline 16 & 66,11 & 4,648 & 58,57 & 8,266 & 142,12 & 6,189 \\
\hline 17 & 71,61 & 3,964 & 85,58 & 7,803 & 148,87 & 8,479 \\
\hline 18 & 67,66 & 6,355 & 54,20 & 3,238 & 134,53 & 7,056 \\
\hline 19 & 74,29 & 5,820 & 79,53 & 0,837 & 155,14 & 11,657 \\
\hline 20 & 66,37 & 5,475 & 47,35 & 5,713 & 140,91 & 9,801 \\
\hline 21 & 64,68 & 5,356 & 60,35 & 13,080 & 133,89 & 4,138 \\
\hline 22 & 58,66 & 5,999 & 44,83 & 1,841 & 123,45 & 6,592 \\
\hline 23 & 76,70 & 7,083 & 73,28 & 1,484 & 155,31 & 7,961 \\
\hline 24 & 73,34 & 5,725 & 84,31 & 7,030 & 154,28 & 10,981 \\
\hline 25 & 77,70 & 7,125 & 68,86 & 5,234 & 154,52 & 8,117 \\
\hline 26 & 68,73 & 6,176 & 44,05 & 2,842 & 145,50 & 10,962 \\
\hline 27 & 61,17 & 7,600 & 47,80 & 8,281 & 144,52 & 8,196 \\
\hline 28 & 71,76 & 6,125 & 56,68 & 2,577 & 143,25 & 5,640 \\
\hline 29 & 78,49 & 6,977 & 71,51 & 5,682 & 162,43 & 15,103 \\
\hline 30 & 71,86 & 2,584 & 65,07 & 9,017 & 151,52 & 7,159 \\
\hline 31 & 74,70 & 8,007 & 55,61 & 5,139 & 157,86 & 14,092 \\
\hline 32 & 71,58 & 4,668 & 66,49 & 2,420 & 146,17 & 6,328 \\
\hline 33 & 66,58 & 6,840 & 57,67 & 4,007 & 135,26 & 11,317 \\
\hline
\end{tabular}


Tabela 15. Médias e Desvios Padrões - Conjunta para dados originais. (continuação). Médias (m) e desvios padrões (s) das 33 progênies ${ }^{1}$ e das testemunhas para os 18 caracteres ${ }^{2}$ avaliados para dados originais nos dois locais. Soja: Anhembi, semeadura em 24/11/1998; ESALQ, semeadura 09/11/1998.

\begin{tabular}{|c|c|c|c|c|c|c|}
\hline \multirow[t]{2}{*}{ Caracteres } & \multicolumn{2}{|c|}{ APM } & \multicolumn{2}{|c|}{ PR } & \multicolumn{2}{|c|}{ DAP } \\
\hline & $\mathbf{m}$ & s & $\mathbf{m}$ & $\mathbf{s}$ & $\mathbf{m}$ & $\mathbf{s}$ \\
\hline \multicolumn{7}{|l|}{ Testemunhas } \\
\hline Céu Azul & 62,71 & 3,618 & 78,14 & 2,882 & 8,54 & 1,241 \\
\hline IAC PL-1 & 60,22 & 5,739 & 81,26 & 0,988 & 6,27 & 2,693 \\
\hline Tamba & 76,98 & 5,225 & 93,81 & 5,032 & 19,01 & 6,178 \\
\hline Nimame & 65,23 & 4,297 & 72,28 & 5,434 & 8,40 & 1,721 \\
\hline Médias & 66,29 & 4,720 & 81,37 & 3,584 & 10,56 & 2,958 \\
\hline \multicolumn{7}{|l|}{ Progênies } \\
\hline 1 & 80,00 & 8,891 & 77,50 & 3,997 & 14,58 & 5,410 \\
\hline 2 & 59,16 & 8,195 & 75,05 & 3,607 & 7,77 & 2,506 \\
\hline 3 & 86,10 & 6,154 & 67,34 & 4,936 & 19,58 & 5,560 \\
\hline 4 & 90,71 & 9,240 & 86,28 & 9,493 & 17,96 & 2,162 \\
\hline 5 & 81,17 & 7,985 & 82,29 & 4,719 & 9,42 & 1,259 \\
\hline 6 & 110,92 & 11,047 & 80,53 & 3,201 & 17,27 & 7,647 \\
\hline 7 & 81,95 & 10,384 & 80,67 & 7,392 & 16,84 & 3,582 \\
\hline 8 & 67,84 & 5,081 & 82,99 & 1,767 & 7,44 & 1,144 \\
\hline 9 & 44,76 & 6,420 & 66,23 & 4,430 & 5,61 & 3,693 \\
\hline 10 & 108,90 & 15,896 & 79,22 & 8,840 & 48,14 & 11,151 \\
\hline 11 & 68,50 & 16,800 & 67,00 & 0,000 & 8,00 & 4,583 \\
\hline 12 & 78,29 & 12,377 & 68,57 & 9,959 & 10,59 & 3,110 \\
\hline 13 & 67,37 & 1,461 & 73,17 & 3,064 & 13,50 & 3,536 \\
\hline 14 & 69,01 & 3,151 & 59,12 & 3,810 & 10,10 & 5,517 \\
\hline 15 & 63,34 & 6,810 & 70,49 & 2,844 & 7,31 & 3,782 \\
\hline 16 & 68,21 & 6,931 & 76,01 & 1,633 & 9,82 & 2,991 \\
\hline 17 & 112,54 & 7,073 & 77,26 & 4,548 & 26,40 & 4,608 \\
\hline 18 & 62,66 & 5,042 & 66,87 & 3,252 & 8,62 & 5,673 \\
\hline 19 & 108,83 & 5,405 & 81,55 & 6,062 & 28,83 & 5,707 \\
\hline 20 & 54,61 & 6,733 & 74,54 & 5,587 & 8,43 & 1,559 \\
\hline 21 & 67,24 & 13,784 & 69,62 & 4,188 & 8,07 & 3,087 \\
\hline 22 & 49,74 & 2,296 & 66,29 & 3,945 & 10,39 & 7,401 \\
\hline 23 & 93,26 & 7,610 & 78,60 & 3,603 & 21,07 & 8,484 \\
\hline 24 & 104,72 & 10,759 & 80,49 & 4,899 & 20,16 & 6,002 \\
\hline 25 & $\mathbf{7 7 , 7 4}$ & 5,926 & 76,82 & 3,135 & 10,17 & 4,684 \\
\hline 26 & 49,56 & 5,559 & 76,77 & 5,442 & 6,26 & 1,971 \\
\hline 27 & 57,26 & 9,666 & 81,92 & 5,989 & 8,89 & 3,072 \\
\hline 28 & 67,30 & 2,185 & 71,49 & 2,624 & 11,31 & 2,368 \\
\hline 29 & 94,63 & 3,379 & 83,94 & 8,591 & 23,13 & 2,549 \\
\hline 30 & 78,57 & 13,655 & 76,89 & 3,434 & 16,94 & 6,619 \\
\hline 31 & 64,86 & 5,340 & 83,47 & 6,334 & 11,23 & 2,705 \\
\hline 32 & 79,29 & 4,250 & 73,69 & 3,558 & 13,08 & 2,850 \\
\hline 33 & 66,22 & 6,225 & 69,70 & 6,075 & 9,78 & 3,735 \\
\hline
\end{tabular}


Tabela 15. Médias e Desvios Padrões - Conjunta para dados originais. (continuação). Médias (m) e desvios padrões (s) das 33 progênies ${ }^{1}$ e das testemunhas para os 18 caracteres $^{2}$ avaliados para dados originais nos dois locais. Soja: Anhembi, semeadura em 24/11/1998; ESALQ, semeadura 09/11/1998.

\begin{tabular}{|c|c|c|c|c|c|c|}
\hline \multirow[t]{2}{*}{ Caracteres } & \multicolumn{2}{|c|}{$\mathrm{AC}$} & \multicolumn{2}{|c|}{ VA } & \multicolumn{2}{|c|}{ LVV } \\
\hline & $\mathbf{m}$ & $\mathbf{s}$ & $\mathbf{m}$ & $\mathbf{s}$ & $\mathbf{m}$ & $\mathbf{s}$ \\
\hline \multicolumn{7}{|l|}{ Testemunhas } \\
\hline Céu Azul & 1,87 & 0,365 & 2,88 & 0,222 & 2,85 & 0,285 \\
\hline IAC PL-1 & 1,38 & 0,238 & 2,59 & 0,341 & 3,16 & 0,243 \\
\hline Tamba & 1,83 & 0,650 & 2,93 & 0,392 & 3,55 & 0,346 \\
\hline Nimame & 2,13 & 0,363 & 2,68 & 0,455 & 2,02 & 0,324 \\
\hline Médias & 1,80 & $\overline{0,404}$ & 2,77 & 0,353 & 2,90 & 0,300 \\
\hline \multicolumn{7}{|l|}{ Progênies } \\
\hline 1 & 1,55 & 0,529 & 2,36 & 0,586 & 2,55 & 0,135 \\
\hline 2 & 1,41 & 0,257 & 2,46 & 0,461 & 2,68 & 0,336 \\
\hline 3 & 2,12 & 0,907 & 2,77 & 0,255 & 3,26 & 0,257 \\
\hline 4 & 2,14 & 0,229 & 3,12 & 0,505 & 3,01 & 0,231 \\
\hline 5 & 1,56 & 0,280 & 3,15 & 0,396 & 3,03 & 0,310 \\
\hline 6 & 2,36 & 0,601 & 2,73 & 0,185 & 2,50 & 0,319 \\
\hline 7 & 1,57 & 0,283 & 3,15 & 0,516 & 2,31 & 0,393 \\
\hline 8 & 1,90 & 0,366 & 2,49 & 0,399 & 2,23 & 0,102 \\
\hline 9 & 1,32 & 0,338 & 2,16 & 0,395 & 2,90 & 0,122 \\
\hline 10 & 1,90 & 0,232 & 2,94 & 0,744 & 3,11 & 0,229 \\
\hline 11 & 1,83 & 0,722 & 2,83 & 1,041 & 2,42 & 1,127 \\
\hline 12 & 1,91 & 0,169 & 2,75 & 0,383 & 3,06 & 0,165 \\
\hline 13 & 2,50 & 0,000 & 3,25 & 0,354 & 2,95 & 0,071 \\
\hline 14 & 1,97 & 0,410 & 2,84 & 0,210 & 1,62 & 0,335 \\
\hline 15 & 1,80 & 0,528 & 2,67 & 0,474 & 2,88 & 0,237 \\
\hline 16 & 1,96 & 0,557 & 3,07 & 0,225 & 3,22 & 0,108 \\
\hline 17 & 2,56 & 0,350 & 3,11 & 0,152 & 2,70 & 0,137 \\
\hline 18 & 1,84 & 0,354 & 3,34 & 0,702 & 3,09 & 0,413 \\
\hline 19 & 2,20 & 0,348 & 3,28 & 0,224 & 3,41 & 0,251 \\
\hline 20 & 1,75 & 0,450 & 2,57 & 0,506 & 3,25 & 0,287 \\
\hline 21 & 2,02 & 0,635 & 2,77 & 0,668 & 3,24 & 0,209 \\
\hline 22 & 2,25 & 0,814 & 2,57 & 0,164 & 3,10 & 0,263 \\
\hline 23 & 2,12 & 0,441 & 3,27 & 0,253 & 2,82 & 0,279 \\
\hline 24 & 2,58 & 0,500 & 2,88 & 0,426 & 2,75 & 0,217 \\
\hline 25 & 1,73 & 0,210 & 2,74 & 0,216 & 2,68 & 0,223 \\
\hline 26 & 1,14 & 0,089 & 2,13 & 0,607 & 1,90 & 0,275 \\
\hline 27 & 1,40 & 0,384 & 2,44 & 0,245 & 2,85 & 0,371 \\
\hline 28 & 1,87 & 0,676 & 2,94 & 0,333 & 2,12 & 0,177 \\
\hline 29 & 2,26 & 0,247 & 3,41 & 0,350 & 2,67 & 0,468 \\
\hline 30 & 1,96 & 0,748 & 2,95 & 0,233 & 3,26 & 0,346 \\
\hline 31 & 1,91 & 0,212 & 2,89 & 0,273 & 2,65 & 0,298 \\
\hline 32 & 1,58 & 0,441 & 3,01 & 0,409 & 2,54 & 0,143 \\
\hline 33 & 1,54 & 0,263 & 2,83 & 0,760 & 2,65 & 0,294 \\
\hline Médias & 1,91 & & 2,86 & & 2,79 & \\
\hline
\end{tabular}


Tabela 15. Médias e Desvios Padrões - Conjunta para dados originais. (continuação). Médias (m) e desvios padrões (s) das 33 progênies ${ }^{1} \mathrm{e}$ das testemunhas para os 18 caracteres $^{2}$ avaliados para dados originais nos dois locais. Soja: Anhembi, semeadura em 24/11/1998; ESALQ, semeadura 09/11/1998.

\begin{tabular}{|c|c|c|c|c|c|c|}
\hline \multirow[t]{2}{*}{ Caracteres } & \multicolumn{2}{|c|}{ PG } & \multicolumn{2}{|c|}{ PCS } & \multicolumn{2}{|c|}{$\% O L$} \\
\hline & m & $\mathbf{s}$ & $\mathbf{m}$ & $\mathbf{s}$ & $\mathbf{m}$ & $\mathbf{s}$ \\
\hline \multicolumn{7}{|l|}{ Testemunhas } \\
\hline Céu Azul & 134,79 & 23,042 & 22,72 & 1,321 & 19,76 & 0,805 \\
\hline IAC PL-1 & 137,96 & 16,044 & 24,48 & 1,266 & 19,84 & 1,044 \\
\hline Tamba & 110,76 & 36,528 & 27,07 & 2,323 & 17,08 & 0,594 \\
\hline Nimame & 91,04 & 18,536 & 17,25 & 1,188 & 19,59 & 0,661 \\
\hline Médias & 118,64 & 23,537 & 22,88 & 1,525 & 19,07 & 0,776 \\
\hline \multicolumn{7}{|l|}{ Progênies } \\
\hline 1 & 67,68 & 14,471 & 21,15 & 1,186 & 16,73 & 0,907 \\
\hline 2 & 139,81 & 23,813 & 22,98 & 0,514 & 20,69 & 0,124 \\
\hline 3 & 127,77 & 38,650 & 24,35 & 0,965 & 18,90 & 0,460 \\
\hline 4 & 86,27 & 28,743 & 23,09 & 1,546 & 16,51 & 0,675 \\
\hline 5 & 130,47 & 17,897 & 23,84 & 1,161 & 18,16 & 0,474 \\
\hline 6 & 122,13 & 29,870 & 20,60 & 2,092 & 18,18 & 1,249 \\
\hline 7 & 122,76 & 35,485 & 18,79 & 2,863 & 17,37 & 1,028 \\
\hline 8 & 108,16 & 34,316 & 19,23 & 1,131 & 19,99 & 1,181 \\
\hline 9 & 100,08 & 5,120 & 23,50 & 0,577 & 20,90 & 0,570 \\
\hline 10 & 109,52 & 43,197 & 23,50 & 0,689 & 19,14 & 1,571 \\
\hline 11 & 126,52 & 9,495 & 22,92 & 6,903 & 19,99 & 1,454 \\
\hline 12 & 167,87 & 49,137 & 24,31 & 0,840 & 20,19 & 0,508 \\
\hline 13 & 177,91 & 46,188 & 22,33 & 0,828 & 20,32 & 1,029 \\
\hline 14 & 131,88 & 23,156 & 15,22 & 1,509 & 20,67 & 1,096 \\
\hline 15 & 86,89 & 18,243 & 23,95 & 1,272 & 18,53 & 2,051 \\
\hline 16 & 156,41 & 13,487 & 24,73 & 0,472 & 19,85 & 1,200 \\
\hline 17 & 174,13 & 25,295 & 21,50 & 0,684 & 20,81 & 0,615 \\
\hline 18 & 111,10 & 25,629 & 24,11 & 1,316 & 20,45 & 0,472 \\
\hline 19 & 139,66 & 28,817 & 25,60 & 1,369 & 18,69 & 1,420 \\
\hline 20 & 122,32 & 35,605 & 23,99 & 1,722 & 19,46 & 1,174 \\
\hline 21 & 112,67 & 35,480 & 24,36 & 0,738 & 20,11 & 1,131 \\
\hline 22 & 108,38 & 12,726 & 23,71 & 0,992 & 21,23 & 0,400 \\
\hline 23 & 149,16 & 36,554 & 21,96 & 1,128 & 18,57 & 0,636 \\
\hline 24 & 160,62 & 45,719 & 22,43 & 0,382 & 19,46 & 0,914 \\
\hline 25 & 139,89 & 34,644 & 21,58 & 0,802 & 18,59 & 1,258 \\
\hline 26 & 108,59 & 16,358 & 17,11 & 0,731 & 18,85 & 0,601 \\
\hline 27 & 89,57 & 27,505 & 21,78 & 2,044 & 17,14 & 0,996 \\
\hline 28 & 130,35 & 18,656 & 18,61 & 1,056 & 18,32 & 0,592 \\
\hline 29 & 98,81 & 46,692 & 22,55 & 3,114 & 16,94 & 1,360 \\
\hline 30 & 116,36 & 35,168 & 24,65 & 1,218 & 19,49 & 0,835 \\
\hline 31 & 127,20 & 8,881 & 21,77 & 0,870 & 18,85 & 0,750 \\
\hline 32 & 107,54 & 24,148 & 20,14 & 0,967 & 19,62 & 0,919 \\
\hline 33 & 121,37 & 16,876 & 20,89 & 0,298 & 20,01 & 0,702 \\
\hline Médias & 124,20 & & 22,25 & & 19,19 & \\
\hline
\end{tabular}

1. Progênies identificadas na Tabela 5.

2. Caracteres identificados no Apêndice 3.

(continua) 
Tabela 15. Médias e Desvios Padrões - Conjunta para dados originais. (continuação). Médias (m) e desvios padrões (s) das 33 progênies ${ }^{1}$ e das testemunhas para os 18 caracteres ${ }^{2}$ avaliados para dados originais nos dois locais. Soja: Anhembi, semeadura em 24/11/1998; ESALQ, semeadura 09/11/1998.

\begin{tabular}{|c|c|c|c|c|c|c|}
\hline \multirow[t]{2}{*}{ Caracteres } & \multicolumn{2}{|c|}{ PO } & \multicolumn{2}{|c|}{ NTV } & \multicolumn{2}{|c|}{$\% \mathrm{~V} 1$} \\
\hline & $\mathbf{m}$ & $\mathbf{s}$ & $\mathbf{m}$ & $\mathbf{s}$ & m & $\mathbf{s}$ \\
\hline \multicolumn{7}{|l|}{ Testemunhas } \\
\hline Céu Azul & 27,18 & 4,974 & 345,19 & 76,192 & 13,50 & 3,857 \\
\hline IAC PL-1 & 27,88 & 3,654 & 355,27 & 58,879 & 17,81 & 3,384 \\
\hline Tamba & 18,76 & 6,506 & 363,80 & 56,635 & 40,46 & 5,727 \\
\hline Nimame & 18,17 & 4,097 & 367,70 & 57,554 & 19,23 & 2,460 \\
\hline Médias & 23,00 & 4,808 & 357,99 & 62,315 & 22,75 & 3,857 \\
\hline \multicolumn{7}{|l|}{ Progênies } \\
\hline 1 & 10,57 & 2,756 & 179,17 & 43,453 & 18,61 & 3,761 \\
\hline 2 & 29,07 & 4,824 & 380,56 & 46,141 & 13,38 & 4,206 \\
\hline 3 & 24,68 & 7,581 & 302,48 & 105,036 & 18,07 & 3,058 \\
\hline 4 & 14,45 & 4,963 & 225,78 & 63,007 & 14,75 & 2,831 \\
\hline 5 & 23,94 & 4,099 & 380,25 & 76,508 & 16,37 & 2,653 \\
\hline 6 & 23,53 & 6,513 & 301,00 & 45,289 & 20,38 & 3,236 \\
\hline 7 & 21,76 & 7,100 & 365,03 & 205,346 & 36,51 & 35,706 \\
\hline 8 & 22,31 & 8,179 & 325,48 & 65,722 & 16,72 & 3,130 \\
\hline 9 & 20,90 & 0,585 & 201,98 & 57,125 & 23,57 & 10,008 \\
\hline 10 & 20,44 & 8,860 & 345,44 & 139,201 & 21,13 & 4,077 \\
\hline 11 & 25,48 & 2,641 & 448,00 & 69,296 & 11,25 & 8,132 \\
\hline 12 & 33,69 & 9,778 & 410,48 & 116,060 & 20,20 & 4,120 \\
\hline 13 & 36,65 & 11,004 & 572,50 & 57,276 & 12,23 & 2,510 \\
\hline 14 & 27,50 & 5,965 & 406,15 & 112,423 & 9,69 & 4,819 \\
\hline 15 & 16,01 & 4,226 & 179,75 & 94,796 & 12,55 & 1,943 \\
\hline 16 & 32,75 & 3,242 & 341,63 & 77,930 & 14,56 & 0,854 \\
\hline 17 & 36,44 & 5,741 & 517,60 & 76,903 & 17,14 & 7,117 \\
\hline 18 & 22,54 & 5,264 & 237,44 & 75,575 & 16,11 & 5,775 \\
\hline 19 & 26,61 & 6,703 & 330,88 & 87,197 & 22,43 & 7,695 \\
\hline 20 & 24,35 & 8,139 & 319,44 & 41,728 & 15,03 & 2,982 \\
\hline 21 & 22,98 & 7,853 & 300,85 & 80,250 & 21,49 & 5,775 \\
\hline 22 & 23,11 & 2,478 & 236,79 & 62,853 & 16,69 & 3,314 \\
\hline 23 & 27,82 & 6,650 & 428,30 & 76,305 & 16,07 & 2,020 \\
\hline 24 & 31,79 & 9,597 & 460,80 & 112,127 & 16,82 & 1,072 \\
\hline 25 & 25,94 & 5,408 & 368,98 & 88,131 & 13,96 & 4,736 \\
\hline 26 & 20,49 & 2,980 & 373,83 & 130,034 & 13,09 & 2,910 \\
\hline 27 & 15,54 & 4,996 & 268,62 & 64,365 & 18,11 & 2,887 \\
\hline 28 & 23,90 & 3,776 & 446,48 & 44,932 & 13,54 & 2,115 \\
\hline 29 & 17,27 & 8,676 & 331,56 & 137,826 & 24,14 & 6,391 \\
\hline 30 & 22,98 & 7,407 & 300,58 & 83,499 & 10,52 & 3,228 \\
\hline 31 & 23,92 & 2,530 & 387,67 & 28,306 & 20,71 & 4,304 \\
\hline 32 & 21,07 & 5,503 & 349,85 & 62,099 & 13,88 & 3,615 \\
\hline 33 & 24,19 & 3,976 & 349,38 & 88,205 & 16,00 & 3,476 \\
\hline
\end{tabular}


Tabela 15. Médias e Desvios Padrões - Conjunta para dados originais. (continuação). Médias (m) e desvios padrões (s) das 33 progênies ${ }^{1}$ e das testemunhas para os 18 caracteres $^{2}$ avaliados para dados originais nos dois locais. Soja: Anhembi, semeadura em 24/11/1998; ESALQ, semeadura 09/11/1998.

\begin{tabular}{|c|c|c|c|c|c|c|}
\hline \multirow[t]{2}{*}{ Caracteres } & \multicolumn{2}{|c|}{$\%$ V2 } & \multicolumn{2}{|c|}{ \%V3 } & \multicolumn{2}{|c|}{ PV } \\
\hline & $\mathbf{m}$ & $\mathbf{s}$ & $\mathbf{m}$ & $\mathbf{s}$ & $\mathbf{m}$ & $\mathbf{s}$ \\
\hline \multicolumn{7}{|l|}{ Testemunhas } \\
\hline Céu Azul & 69,29 & 4,864 & 15,56 & 6,037 & 245,45 & 59,650 \\
\hline IAC PL-1 & 66,94 & 4,651 & 15,24 & 6,344 & 236,05 & 23,826 \\
\hline Tamba & 55,02 & 5,361 & 4,51 & 1,448 & 212,28 & 60,543 \\
\hline Nimame & 66,93 & 3,646 & 13,84 & 5,110 & 176,15 & 29,862 \\
\hline Média & 64,55 & 4,631 & 12,29 & 4,734 & 217,48 & 43,470 \\
\hline \multicolumn{7}{|l|}{ Progênies } \\
\hline 1 & 64,11 & 1,183 & 17,28 & 4,197 & 113,04 & 41,376 \\
\hline 2 & 70,50 & 2,908 & 16,13 & 1,451 & 229,38 & 39,120 \\
\hline 3 & 66,49 & 6,452 & 16,06 & 3,585 & 200,61 & 58,812 \\
\hline 4 & 59,30 & 3,179 & 25,95 & 1,196 & 154,89 & 30,343 \\
\hline 5 & 64,58 & 5,421 & 18,56 & 3,383 & 247,08 & 42,661 \\
\hline 6 & 63,26 & 5,409 & 16,36 & 2,731 & 167,49 & 39,125 \\
\hline 7 & 56,24 & 29,428 & 7,25 & 6,280 & 194,00 & 50,344 \\
\hline 8 & 64,81 & 4,048 & 18,47 & 4,826 & 166,68 & 32,681 \\
\hline 9 & 58,91 & 11,615 & 17,52 & 5,924 & 214,01 & 137,969 \\
\hline 10 & 57,45 & 7,124 & 22,05 & 4,072 & 208,61 & 83,089 \\
\hline 11 & 43,00 & 10,607 & 45,75 & 18,738 & 212,74 & 27,195 \\
\hline 12 & 61,37 & 8,470 & 18,43 & 8,607 & 277,14 & 39,693 \\
\hline 13 & 79,30 & 3,818 & 8,48 & 6,329 & 287,96 & 23,066 \\
\hline 14 & 39,88 & 4,090 & 50,44 & 2,831 & 185,22 & 49,462 \\
\hline 15 & 72,88 & 5,391 & 14,58 & 5,449 & 165,82 & 38,076 \\
\hline 16 & 72,68 & 3,526 & 12,76 & 2,733 & 260,77 & 52,974 \\
\hline 17 & 68,87 & 11,661 & 13,99 & 13,113 & 301,09 & 50,719 \\
\hline 18 & 56,87 & 7,326 & 27,03 & 8,760 & 166,15 & 48,296 \\
\hline 19 & 55,79 & 5,369 & 21,66 & 2,547 & 224,36 & 58,014 \\
\hline 20 & 71,41 & 3,064 & 11,46 & 1,751 & 211,52 & 29,744 \\
\hline 21 & 61,65 & 8,010 & 16,86 & 4,096 & 197,71 & 58,225 \\
\hline 22 & 62,27 & 12,076 & 21,04 & 9,357 & 153,55 & 46,166 \\
\hline 23 & 56,87 & 4,851 & 27,06 & 4,526 & 243,10 & 66,009 \\
\hline 24 & 72,10 & 4,002 & 7,96 & 3,701 & 277,46 & 50,795 \\
\hline 25 & 63,56 & 7,034 & 23,93 & 4,862 & 232,93 & 20,427 \\
\hline 26 & 66,95 & 5,303 & 19,96 & 7,391 & 173,75 & 51,153 \\
\hline 27 & 58,63 & 1,279 & 23,26 & 3,137 & 159,36 & 36,977 \\
\hline 28 & 68,76 & 2,858 & 17,70 & 4,382 & 200,01 & 32,133 \\
\hline 29 & 64,32 & 6,995 & 11,55 & 0,709 & 175,80 & 89,549 \\
\hline 30 & 65,67 & 4,365 & 23,81 & 3,722 & 198,76 & 57,160 \\
\hline 31 & 67,88 & 6,508 & 11,42 & 4,636 & 199,01 & 24,751 \\
\hline 32 & 63,29 & 5,523 & 22,83 & 2,626 & 177,38 & 37,103 \\
\hline 33 & 62,09 & 7,760 & 21,91 & 6,952 & 203,09 & 36,171 \\
\hline Médias & 63,01 & & 19,01 & & 208,80 & \\
\hline
\end{tabular}


Tabela 16. Progênies em relação à média das testemunhas. Dados originais Desempenho relativo das 33 progênies $^{1}$ em porcentagem da média de testemunha para os 18 caracteres $^{2}$ avaliados para os dois locais. Soja: Anhembi, semeadura em 24/11/1998; ESALQ, semeadura 09/11/1998.

\begin{tabular}{|c|c|c|c|c|c|c|}
\hline \multirow[t]{2}{*}{ Caracteres } & \multicolumn{2}{|c|}{$\mathrm{NDF}$} & \multicolumn{2}{|c|}{$\overline{A P F}$} & \multicolumn{2}{|c|}{ NDM } \\
\hline & Anhembi & ESALQ & Anhembi & ESALQ & Anhembi & ESALQ \\
\hline \multicolumn{7}{|l|}{ Progênies } \\
\hline 1 & 8,94 & 7,26 & 20,62 & 12,27 & 1,99 & 1,11 \\
\hline 2 & 6,62 & 2,32 & 0,15 & $-15,38$ & $-1,50$ & $-2,05$ \\
\hline 3 & 0,91 & 8,57 & 12,52 & 22,61 & $-10,77$ & $-3,58$ \\
\hline 4 & 6,21 & 5,00 & 25,13 & 32,09 & 1,82 & 8,15 \\
\hline 5 & 14,15 & 5,13 & 22,62 & 32,03 & 5,50 & 8,98 \\
\hline 6 & 15,27 & 7,71 & 69,83 & 58,74 & 5,42 & 7,02 \\
\hline 7 & 10,45 & 2,56 & 26,55 & 9,96 & 3,14 & 6,58 \\
\hline 8 & 2,93 & 16,11 & 6,18 & 11,56 & 2,95 & 2,49 \\
\hline 9 & $-10,80$ & 15,69 & $-25,95$ & $-32,07$ & $-15,88$ & $-15,62$ \\
\hline 10 & 13,40 & 13,98 & 13,27 & 20,64 & 6,99 & 10,17 \\
\hline 11 & 3,54 & 4,56 & 2,62 & 8,19 & $-7,42$ & $-14,05$ \\
\hline 12 & 10,86 & $-15,12$ & 37,75 & 13,03 & 1,50 & $-11,90$ \\
\hline 13 & 12,09 & 6,69 & 3,34 & $-12,52$ & $-0,87$ & 2,25 \\
\hline 14 & 1,35 & $-16,96$ & 5,72 & 6,89 & $-16,28$ & $-13,05$ \\
\hline 15 & $-7,32$ & 13,35 & 7,62 & $-5,57$ & $-8,13$ & $-15,63$ \\
\hline 16 & 2,44 & 16,40 & $-7,28$ & 14,09 & $-2,42$ & $-4,33$ \\
\hline 17 & 12,13 & 1,39 & 47,09 & 55,49 & 0,81 & 1,51 \\
\hline 18 & 2,17 & $-13,56$ & $-5,14$ & $-3,15$ & $-8,09$ & $-9,01$ \\
\hline 19 & 13,81 & $-0,78$ & 42,50 & 38,90 & 3,56 & 7,14 \\
\hline 20 & 1,35 & 6,46 & $-19,13$ & $-13,47$ & $-5,29$ & $-3,28$ \\
\hline 21 & $-0,67$ & 3,86 & 25,24 & $-11,13$ & $-6,56$ & $-11,24$ \\
\hline 22 & $-12,00$ & 12,60 & $-20,93$ & $-20,49$ & $-15,88$ & $-16,31$ \\
\hline 23 & 16,74 & 0,90 & 31,93 & 27,37 & 5,77 & 5,34 \\
\hline 24 & 12,63 & $-2,16$ & 62,65 & 36,05 & 3,11 & 6,44 \\
\hline 25 & 17,68 & $-9,46$ & 30,58 & 13,30 & 5,28 & 4,76 \\
\hline 26 & 4,19 & 16,94 & $-17,05$ & $-26,96$ & $-2,64$ & 0,27 \\
\hline 27 & $-10,10$ & 10,92 & $-19,57$ & $-11,49$ & $-0,74$ & $-2,75$ \\
\hline 28 & 9,27 & 18,96 & 1,27 & $-0,74$ & $-1,09$ & $-4,07$ \\
\hline 29 & 19,12 & 5,13 & 33,38 & 19,80 & 6,52 & 13,92 \\
\hline 30 & 14,64 & $-3,98$ & 9,15 & 20,81 & 3,53 & 2,47 \\
\hline 31 & 11,49 & 9,34 & $-6,69$ & 3,22 & 3,97 & 10,30 \\
\hline 32 & 11,09 & 19,95 & 18,46 & 16,77 & 1,15 & $-2,32$ \\
\hline 33 & 0,38 & 15,79 & 4,30 & $-0,21$ & $-9,75$ & $-6,54$ \\
\hline
\end{tabular}


Tabela 16. Progênies em relação à média das testemunhas. Dados originais (continuação). Desempenho relativo das 33 progênies ${ }^{1}$ em porcentagem da média de testemunha para os 18 caracteres $^{2}$ avaliados para os dois locais. Soja: Anhembi, semeadura em 24/1 1/1998; ESALQ, semeadura 09/11/1998.

\begin{tabular}{|c|c|c|c|c|c|c|}
\hline \multirow[t]{2}{*}{ Caracteres } & \multicolumn{2}{|c|}{$\overline{\mathrm{APM}}$} & \multicolumn{2}{|c|}{$\overline{\mathrm{PR}}$} & \multicolumn{2}{|c|}{$\overline{\text { DAP }}$} \\
\hline & Anhembi & ESALQ & Anhembi & ESALQ & Anhembi & ESALQ \\
\hline \multicolumn{7}{|l|}{ Progênies } \\
\hline 1 & 26,41 & 14,71 & $-3,37$ & $-6,08$ & 48,47 & 23,02 \\
\hline 2 & $-3,24$ & $-18,60$ & $-7,50$ & $-8,03$ & $-21,05$ & $-34,13$ \\
\hline 3 & 21,38 & 38,76 & $-19,52$ & $-15,09$ & 57,23 & 126,48 \\
\hline 4 & 27,05 & 47,06 & $-1,27$ & 12,97 & 31,91 & 125,70 \\
\hline 5 & 13,87 & 31,40 & $-0,89$ & 3,04 & $-28,26$ & 14,58 \\
\hline 6 & 55,36 & 79,81 & $-1,88$ & $-0,23$ & $-13,39$ & 175,49 \\
\hline 7 & 31,85 & 15,05 & $-2,21$ & 0,41 & 59,36 & 59,83 \\
\hline 8 & $-0,73$ & 5,56 & 3,21 & 0,82 & $-34,24$ & $-22,70$ \\
\hline 9 & $-26,32$ & $-38,90$ & $-20,80$ & $-16,52$ & $-31,57$ & $-69,00$ \\
\hline 10 & 55,37 & 73,57 & $-0,30$ & $-4,88$ & 358,55 & 352,37 \\
\hline 11 & 3,41 & 4,42 & $-15,61$ & $-19,62$ & 3,93 & $-36,07$ \\
\hline 12 & 28,38 & 7,38 & $-6,34$ & $-24,67$ & 1,53 & $-1,39$ \\
\hline 13 & 1,05 & 2,24 & $-10,57$ & $-9,63$ & $-12,06$ & 85,98 \\
\hline 14 & 5,87 & 2,27 & $-29,60$ & $-25,19$ & 16,70 & $-34,96$ \\
\hline 15 & 2,26 & $-11,45$ & $-8,54$ & $-17,97$ & $-16,06$ & $-52,05$ \\
\hline 16 & $-6,74$ & 12,96 & $-5,91$ & $-7,25$ & $-7,03$ & $-6,86$ \\
\hline 17 & 60,94 & 79,00 & $-7,63$ & $-2,60$ & 117,28 & 197,86 \\
\hline 18 & $-2,18$ & $-8,90$ & $-15,73$ & $-19,82$ & 8,13 & $-56,83$ \\
\hline 19 & 63,73 & 64,64 & $-2,80$ & 3,10 & 145,83 & 212,71 \\
\hline 20 & $-19,49$ & $-15,67$ & $-10,15$ & $-6,74$ & $-23,39$ & $-15,31$ \\
\hline 21 & 11,42 & $-8,97$ & $-9,82$ & $-18,85$ & $-37,64$ & $-3,00$ \\
\hline 22 & $-23,67$ & $-26,32$ & $-18,76$ & $-18,32$ & $-33,19$ & 44,47 \\
\hline 23 & 43,63 & 37,62 & $-2,38$ & $-4,38$ & 91,43 & 111,62 \\
\hline 24 & 61,17 & 54,66 & $-3,95$ & 1,64 & 85,23 & 99,41 \\
\hline 25 & 20,67 & 13,74 & $-3,97$ & $-7,15$ & $-6,23$ & 0,10 \\
\hline 26 & $-20,30$ & $-30,37$ & $-7,66$ & $-3,76$ & $-39,71$ & $-42,05$ \\
\hline 27 & $-17,35$ & $-9,73$ & 6,67 & $-5,06$ & $-9,90$ & $-24,24$ \\
\hline 28 & 0,75 & 2,32 & $-8,80$ & $-15,32$ & 6,71 & 7,84 \\
\hline 29 & 42,53 & 43,01 & $-2,88$ & 8,91 & 79,05 & 177,32 \\
\hline 30 & 5,44 & 32,19 & $-4,74$ & $-6,25$ & 40,90 & 89,03 \\
\hline 31 & $-8,17$ & 4,12 & $-0,45$ & 5,45 & $-9,78$ & 29,80 \\
\hline 32 & 18,31 & 20,99 & $-6,24$ & $-12,50$ & 14,21 & 37,93 \\
\hline 33 & $-2,72$ & 2,62 & $-17,31$ & $-11,53$ & $-10,76$ & $-2,36$ \\
\hline
\end{tabular}


Tabela 16. Progênies em relação à média das testemunhas. Dados originais (continuação). Desempenho relativo das 33 progênies ${ }^{1}$ em porcentagem da média de testemunha para os 18 caracteres $^{2}$ avaliados para os dois locais. Soja: Anhembi, semeadura em 24/11/1998; ESALQ, semeadura 09/11/1998.

\begin{tabular}{|c|c|c|c|c|c|c|}
\hline \multirow[t]{2}{*}{ Caracteres } & \multicolumn{2}{|c|}{$\mathrm{AC}$} & \multicolumn{2}{|c|}{ VA } & \multicolumn{2}{|c|}{ LVV } \\
\hline & Anhembi & ESALQ & Anhembi & ESALQ & Anhembi & ESALQ \\
\hline \multicolumn{7}{|l|}{ Progênies } \\
\hline 1 & $-6,41$ & $-21,99$ & $-6,38$ & $-24,81$ & $-8,52$ & $-15,04$ \\
\hline 2 & $-23,12$ & $-20,56$ & $-5,48$ & $-17,96$ & $-1,31$ & $-13,50$ \\
\hline 3 & 17,55 & 17,93 & 0,12 & $-0,05$ & 7,10 & 17,73 \\
\hline 4 & 8,64 & 29,34 & 18,67 & 5,59 & 3,08 & 4,79 \\
\hline 5 & $-15,00$ & $-11,72$ & 14,77 & 12,09 & 3,39 & 6,05 \\
\hline 6 & 23,01 & 38,92 & $-10,39$ & 8,84 & $-13,45$ & $-13,62$ \\
\hline 7 & $-26,02$ & 1,24 & 12,02 & 15,88 & $-11,69$ & $-28,82$ \\
\hline 8 & $-3,06$ & 14,25 & $-8,42$ & $-11,79$ & $-20,83$ & $-25,02$ \\
\hline 9 & $-26,46$ & $-27,00$ & $-17,59$ & $-26,82$ & $-1,62$ & 1,96 \\
\hline 10 & $-7,55$ & 19,07 & 12,10 & $-0,79$ & 9,03 & 5,90 \\
\hline 11 & $-46,52$ & 29,34 & 34,42 & $-12,28$ & $-56,14$ & 1,96 \\
\hline 12 & 3,91 & 7,78 & 2,74 & $-4,97$ & 9,28 & 1,96 \\
\hline 13 & 33,70 & 43,71 & 17,62 & 16,97 & 1,76 & 1,96 \\
\hline 14 & $-1,95$ & 21,13 & $-6,65$ & 12,79 & $-51,26$ & $-36,88$ \\
\hline 15 & $-25,72$ & 27,54 & 0,82 & $-8,62$ & $-5,45$ & 4,08 \\
\hline 16 & 3,14 & 14,37 & 2,98 & 19,81 & 13,29 & 9,39 \\
\hline 17 & 30,14 & 54,57 & 2,68 & 23,03 & $-9,35$ & $-4,28$ \\
\hline 18 & $-11,42$ & 16,57 & 29,17 & 10,47 & 8,34 & 4,79 \\
\hline 19 & 31,48 & 11,12 & 3,62 & 35,24 & 12,58 & 22,49 \\
\hline 20 & 0,28 & $-6,07$ & $-9,68$ & $-4,62$ & 19,16 & 5,75 \\
\hline 21 & 26,54 & $-3,51$ & 5,62 & $-6,71$ & 18,11 & 5,60 \\
\hline 22 & 16,43 & 33,96 & $-11,79$ & $-2,18$ & 9,66 & 4,69 \\
\hline 23 & $-7,15$ & 43,71 & 15,75 & 20,76 & $-4,48$ & $-0,76$ \\
\hline 24 & 52,46 & 32,68 & 6,53 & 0,60 & $-8,25$ & $-1,84$ \\
\hline 25 & 0,65 & $-9,18$ & $-4,67$ & 3,29 & $-9,35$ & $-5,48$ \\
\hline 26 & $-38,16$ & $-35,67$ & $-13,19$ & $-34,56$ & $-40,42$ & $-28,39$ \\
\hline 27 & $-22,75$ & $-21,99$ & $-13,05$ & $-10,88$ & 5,69 & $-8,97$ \\
\hline 28 & 29,81 & $-24,15$ & $-1,40$ & 14,80 & $-23,24$ & $-30,14$ \\
\hline 29 & 15,88 & 35,50 & 24,62 & 21,14 & $-15,57$ & $-0,47$ \\
\hline 30 & 37,05 & $-21,76$ & 2,92 & 10,78 & 7,46 & 17,73 \\
\hline 31 & 0,28 & 11,77 & $-10,27$ & 21,30 & $-15,08$ & $-1,82$ \\
\hline 32 & $-34,42$ & 11,38 & 4,62 & 13,31 & $-12,69$ & $-11,85$ \\
\hline 33 & $-11,42$ & $-17,61$ & 8,52 & $-5,13$ & $-12,15$ & $-5,12$ \\
\hline
\end{tabular}


Tabela 16. Progênies em relação à média das testemunhas. Dados originais (continuação). Desempenho relativo das 33 progênies ${ }^{1}$ em porcentagem da média de testemunha para os 18 caracteres $^{2}$ avaliados para os dois locais. Soja: Anhembi, semeadura em 24/11/1998; ESALQ, semeadura 09/11/1998.

\begin{tabular}{|c|c|c|c|c|c|c|}
\hline \multirow[t]{2}{*}{ Caracteres } & \multicolumn{2}{|c|}{ PG } & \multicolumn{2}{|c|}{ PCS } & \multicolumn{2}{|c|}{$\% \mathrm{OL}$} \\
\hline & Anhembi & ESALQ & Anhembi & ESALQ & Anhembi & ESALQ \\
\hline \multicolumn{7}{|l|}{ Progênies } \\
\hline 1 & $-41,65$ & $-44,60$ & $-3,35$ & $-11,78$ & $-10,30$ & $-14,31$ \\
\hline 2 & 20,80 & 14,12 & 2,06 & $-1,21$ & 7,44 & 9,62 \\
\hline 3 & 15,56 & $-2,26$ & 6,30 & 6,50 & $-0,33$ & $-1,49$ \\
\hline 4 & $-17,00$ & $-40,33$ & $-0,73$ & 2,59 & $-13,03$ & $-13,86$ \\
\hline 5 & $-2,49$ & 25,79 & 5,74 & 2,61 & $-6,76$ & $-2,79$ \\
\hline 6 & 5,13 & 0,18 & $-9,39$ & $-10,59$ & $-10,39$ & 1,17 \\
\hline 7 & 7,91 & $-2,15$ & $-13,49$ & $-22,29$ & $-7,88$ & $-9,96$ \\
\hline 8 & $-4,37$ & $-14,50$ & $-15,11$ & $-16,78$ & 5,17 & 4,43 \\
\hline 9 & $-24,61$ & $-4,26$ & 3,43 & 1,97 & 9,43 & 9,77 \\
\hline 10 & 7,82 & $-27,34$ & 5,07 & 0,37 & 1,85 & $-1,15$ \\
\hline 11 & 3,46 & 15,80 & $-34,22$ & 17,44 & 3,54 & 5,81 \\
\hline 12 & 51,41 & 28,94 & 7,90 & 4,55 & 3,17 & 8,57 \\
\hline 13 & 58,74 & 38,83 & 0,05 & $-4,88$ & 9,70 & 3,41 \\
\hline 14 & $-11,43$ & 39,81 & $-39,08$ & $-27,92$ & 7,43 & 9,36 \\
\hline 15 & $-37,24$ & $-13,47$ & 1,42 & 7,95 & $-11,86$ & 6,36 \\
\hline 16 & 19,71 & 47,23 & 7,79 & 8,38 & 2,89 & 5,34 \\
\hline 17 & 33,53 & 63,57 & $-5,81$ & $-6,25$ & 9,21 & 9,07 \\
\hline 18 & $-2,11$ & $-11,73$ & 2,78 & 7,95 & 7,11 & 7,34 \\
\hline 19 & 21,64 & 12,76 & 6,76 & 16,99 & 2,78 & $-6,80$ \\
\hline 20 & 14,88 & $-11,82$ & 10,28 & $-0,60$ & 6,42 & $-2,38$ \\
\hline 21 & 2,87 & $-15,04$ & 8,69 & 4,19 & 6,47 & 4,39 \\
\hline 22 & $-13,19$ & $-2,89$ & 4,75 & 2,46 & 8,97 & 13,67 \\
\hline 23 & 29,64 & 20,78 & $-4,69$ & $-3,34$ & $-5,02$ & $-0,15$ \\
\hline 24 & 39,50 & 30,18 & $-0,66$ & $-3,29$ & 4,17 & $-0,06$ \\
\hline 25 & 26,68 & 6,80 & $-6,49$ & $-4,85$ & $-6,84$ & 1,85 \\
\hline 26 & $-14,20$ & $-1,20$ & $-27,27$ & $-23,13$ & $-0,30$ & $-1,97$ \\
\hline 27 & $-14,95$ & $-36,62$ & 0,14 & $-9,76$ & $-9,09$ & $-11,20$ \\
\hline 28 & 5,70 & 15,16 & $-15,95$ & $-21,43$ & $-2,06$ & $-5,79$ \\
\hline 29 & 3,27 & $-42,05$ & $-12,66$ & 9,75 & $-7,35$ & $-15,06$ \\
\hline 30 & 5,30 & $-11,07$ & 6,26 & 9,16 & 4,56 & $-0,17$ \\
\hline 31 & $-4,94$ & 22,63 & $-6,18$ & $-3,51$ & $-0,84$ & $-1,42$ \\
\hline 32 & $-3,79$ & $-16,39$ & $-10,22$ & $-13,74$ & 5,66 & 0,03 \\
\hline 33 & $-1,87$ & 7,60 & $-8,56$ & $-8,84$ & 7,16 & 2,67 \\
\hline
\end{tabular}


Tabela 16. Progênies em relação à média das testemunhas. Dados originais (continuação). Desempenho relativo das 33 progênies $^{1}$ em porcentagem da média de testemunha para os 18 caracteres $^{2}$ avaliados para os dois locais. Soja: Anhembi, semeadura em 24/1 1/1998; ESALQ, semeadura 09/11/1998.

\begin{tabular}{|c|c|c|c|c|c|c|}
\hline \multirow[t]{2}{*}{ Caracteres } & \multicolumn{2}{|c|}{ PO } & \multicolumn{2}{|c|}{ NTV } & \multicolumn{2}{|c|}{$\% \mathrm{V1}$} \\
\hline & Anhembi & ESALQ & Anhembi & ESALQ & Anhembi & ESALQ \\
\hline \multicolumn{7}{|l|}{ Progênies } \\
\hline 1 & $-51,02$ & $-58,04$ & 2,36 & $-50,44$ & $-23,78$ & $-12,52$ \\
\hline 2 & 27,59 & 24,81 & $-2,37$ & 1,95 & $-26,71$ & $-56,07$ \\
\hline 3 & 13,81 & $-1,21$ & $-49,53$ & $-5,63$ & $-17,59$ & $-23,64$ \\
\hline 4 & $-28,76$ & $-48,08$ & $-4,33$ & $-46,83$ & $-36,66$ & $-33,61$ \\
\hline 5 & $-11,49$ & 24,32 & 10,14 & 31,21 & $-36,55$ & $-19,37$ \\
\hline 6 & 3,35 & 0,92 & $-24,21$ & $-5,07$ & $-0,97$ & $-20,11$ \\
\hline 7 & $-1,39$ & $-10,57$ & $-28,21$ & 37,93 & 237,47 & $-29,20$ \\
\hline 8 & 1,87 & $-9,31$ & $-15,80$ & $-13,76$ & $-34,04$ & $-18,82$ \\
\hline 9 & $-19,67$ & 4,55 & $-25,48$ & $-48,97$ & $-20,70$ & 28,45 \\
\hline 10 & 3,14 & $-29,68$ & $-55,34$ & $-28,95$ & $-10,26$ & $-3,97$ \\
\hline 11 & 5,62 & 22,49 & $-4,96$ & 18,98 & $-100,00$ & $-24,38$ \\
\hline 12 & 54,27 & 36,38 & $-38,83$ & 0,13 & $-0,47$ & $-22,21$ \\
\hline 13 & 70,82 & 44,46 & 18,91 & 82,80 & $-54,61$ & $-37,72$ \\
\hline 14 & $-5,91$ & 52,73 & 30,57 & 20,77 & $-46,25$ & $-68,86$ \\
\hline 15 & $-45,74$ & $-10,39$ & 27,46 & $-55,49$ & $-49,62$ & $-39,95$ \\
\hline 16 & 32,74 & 54,98 & 39,76 & 10,93 & $-33,58$ & $-38,46$ \\
\hline 17 & 43,17 & 78,29 & 7,00 & 59,09 & $-43,05$ & $-5,81$ \\
\hline 18 & 2,08 & $-7,34$ & $-44,76$ & $-48,04$ & $-39,36$ & $-18,82$ \\
\hline 19 & 23,06 & 6,10 & $-18,23$ & $-6,44$ & $-4,01$ & 1,20 \\
\hline 20 & 20,06 & $-12,64$ & 31,80 & $-13,19$ & $-28,44$ & $-39,58$ \\
\hline 21 & 7,70 & $-10,26$ & $-21,02$ & $-22,37$ & 5,61 & $-16,96$ \\
\hline 22 & $-7,20$ & 10,50 & $-8,58$ & $-25,82$ & $-19,07$ & $-34,39$ \\
\hline 23 & 20,50 & 21,51 & $-8,64$ & 18,35 & $-23,93$ & $-34,94$ \\
\hline 24 & 42,08 & 33,24 & $-10,32$ & 21,37 & $-25,60$ & $-26,60$ \\
\hline 25 & 16,72 & 7,69 & $-40,93$ & $-1,19$ & $-31,54$ & $-45,92$ \\
\hline 26 & $-16,74$ & $-3,36$ & 20,78 & $-4,45$ & $-48,53$ & $-36,28$ \\
\hline 27 & $-24,69$ & $-42,49$ & 35,19 & $-34,25$ & $-31,04$ & $-9,53$ \\
\hline 28 & 0,68 & 8,07 & 6,83 & 37,72 & $-46,79$ & $-34,05$ \\
\hline 29 & $-6,69$ & $-48,66$ & 12,24 & $-28,06$ & 22,89 & $-11,11$ \\
\hline 30 & 8,31 & $-11,07$ & $-16,79$ & $-29,33$ & $-58,01$ & $-49,40$ \\
\hline 31 & $-9,26$ & 21,23 & 13,26 & 9,89 & $-10,24$ & $-7,70$ \\
\hline 32 & $-1,15$ & $-17,78$ & 10,83 & $-7,53$ & $-34,09$ & $-44,02$ \\
\hline 33 & 2,65 & 8,46 & 6,88 & $-2,45$ & $-35,83$ & $-23,38$ \\
\hline
\end{tabular}


Tabela 16. Progênies em relação à média das testemunhas. Dados origınats (continuação). Desempenho relativo das 33 progênies ${ }^{1}$ em porcentagem da média de testemunha para os 18 caracteres $^{2}$ avaliados para os dois locais. Soja: Anhembi, semeadura em 24/1 1/1998; ESALQ, semeadura 09/11/1998.

\begin{tabular}{|c|c|c|c|c|c|c|}
\hline \multirow[t]{2}{*}{ Caracteres } & \multicolumn{2}{|c|}{$\% \mathrm{~V} 2$} & \multicolumn{2}{|c|}{$\% \mathrm{V3}$} & \multicolumn{2}{|c|}{ PV } \\
\hline & Anhembi & ESALQ & Anhembi & ESALQ & Anhembi & ESALQ \\
\hline \multicolumn{7}{|l|}{ Progênie } \\
\hline 1 & 1,67 & $-2,85$ & 29,98 & 56,62 & $-44,59$ & $-51,98$ \\
\hline 2 & 9,75 & 8,73 & 0,57 & 77,48 & 12,31 & $-2,41$ \\
\hline 3 & 0,75 & 5,12 & 24,23 & 40,45 & $-12,39$ & $-2,42$ \\
\hline 4 & $-5,24$ & $-10,81$ & 79,11 & 159,45 & $-27,41$ & $-30,36$ \\
\hline 5 & 3,56 & $-3,22$ & 35,16 & 74,92 & $-5,76$ & 35,93 \\
\hline 6 & $-5,36$ & 1,14 & 24,07 & 46,83 & $-27,35$ & $-17,96$ \\
\hline 7 & $-64,14$ & 9,42 & $-100,00$ & 11,08 & $-100,00$ & $-4,00$ \\
\hline 8 & $-0,04$ & 0,82 & 53,14 & 45,98 & $-17,42$ & $-30,20$ \\
\hline 9 & 0,75 & $-17,53$ & 29,08 & 62,92 & $-35,90$ & 37,93 \\
\hline 10 & $-7,45$ & $-14,28$ & 47,31 & 127,91 & 16,89 & $-28,24$ \\
\hline 11 & $-42,91$ & $-24,52$ & 298,90 & 231,97 & $-0,39$ & $-4,24$ \\
\hline 12 & 2,17 & $-11,51$ & $-8,39$ & 138,04 & 30,20 & 24,25 \\
\hline 13 & 23,18 & 22,56 & $-12,44$ & $-59,14$ & 30,66 & 34,42 \\
\hline 14 & $-36,48$ & $-39,84$ & 225,38 & 438,81 & $-26,68$ & $-1,18$ \\
\hline 15 & 12,57 & 13,22 & 24,40 & 9,80 & $-27,10$ & $-19,89$ \\
\hline 16 & 12,33 & 12,84 & 0,46 & 8,95 & $-5,66$ & 49,37 \\
\hline 17 & 4,51 & 8,73 & 48,07 & $-37,95$ & 18,81 & 61,07 \\
\hline 18 & $-15,72$ & $-8,34$ & 127,34 & 108,63 & $-11,19$ & $-37,91$ \\
\hline 19 & $-9,81$ & $-17,05$ & 47,50 & 119,61 & 4,52 & 1,60 \\
\hline 20 & 14,28 & 7,24 & $-15,74$ & 6,74 & 0,54 & $-6,52$ \\
\hline 21 & $-10,80$ & 1,38 & 36,69 & 37,89 & $-4,51$ & $-14,37$ \\
\hline 22 & $-6,27$ & $-0,98$ & 56,07 & 94,07 & $-37,36$ & $-20,21$ \\
\hline 23 & $-9,36$ & $-14,25$ & 76,58 & 186,00 & 19,96 & 2,36 \\
\hline 24 & 19,96 & 4,03 & $-44,15$ & $-21,69$ & 32,00 & 22,49 \\
\hline 25 & 1,85 & $-4,66$ & 49,76 & 162,68 & 3,66 & 11,07 \\
\hline 26 & 0,69 & 6,54 & 72,66 & 47,00 & $-22,35$ & $-17,53$ \\
\hline 27 & $-6,45$ & $-11,69$ & 75,43 & 110,16 & $-17,97$ & $-36,82$ \\
\hline 28 & 7,34 & 5,78 & 41,98 & 47,09 & $-13,58$ & $-1,64$ \\
\hline 29 & $-3,79$ & 2,85 & $-19,61$ & 14,40 & 6,65 & $-48,91$ \\
\hline 30 & 1,85 & 1,63 & 82,55 & 110,67 & 4,90 & $-24,17$ \\
\hline 31 & 2,92 & 7,24 & 3,67 & $-23,39$ & $-10,03$ & $-6,72$ \\
\hline 32 & $-3,78$ & $-0,23$ & 68,97 & 111,10 & $-11,09$ & $-26,91$ \\
\hline 33 & 0,30 & $-7,63$ & 54,49 & 114,25 & $-12,52$ & 0,19 \\
\hline
\end{tabular}


Tabela 17. Médias ${ }^{1}$ (m) e classificações ${ }^{2}$ (SK). Médias e classificações (SK) pelo teste de Scott-Knott das 33 progênies ${ }^{3}$ e quatro testemunhas avaliadas com base na média de repetições para os 18 caracteres avaliados ${ }^{4}$ para os dois locais. Soja: Anhembi, semeadura em 24/11/1998; ESALQ, semeadura 09/11/1998.

\begin{tabular}{|c|c|c|c|c|c|c|c|c|c|c|c|}
\hline \multirow[t]{2}{*}{ Caracteres } & \multicolumn{2}{|c|}{$\overline{\text { NDF }}$} & $\overline{\mathrm{APF}}$ & \multicolumn{2}{|c|}{ NDM } & \multicolumn{2}{|c|}{$\overline{\mathrm{APM}}$} & \multicolumn{2}{|c|}{ PR } & \multicolumn{2}{|c|}{$\overrightarrow{D A P}$} \\
\hline & $\mathbf{m}$ & SK & SK & $\mathbf{m}$ & SK & $\mathbf{m}$ & SK & $\mathbf{m}$ & SK & $\mathbf{m}$ & SK \\
\hline \multicolumn{12}{|l|}{ Testemunhas } \\
\hline Céu Azul & 66,29 & B & 55,44 & 144,43 & B & 62,71 & D & 78,14 & $\mathbf{A}$ & 8,54 & D \\
\hline IAC PL-1 & 67,28 & B & 54,79 & 148,58 & B & 60,22 & D & 81,26 & $\mathbf{A}$ & 6,27 & D \\
\hline Tamba & 63,96 & B & 58,23 & 158,31 & $\mathbf{A}$ & 76,98 & C & 93,81 & $\mathbf{A}$ & 19,01 & C \\
\hline Nimame & 65,05 & B & 57,71 & 137,26 & $\mathrm{C}$ & 65,23 & D & 72,28 & B & 8,40 & D \\
\hline \multicolumn{12}{|l|}{ Progênies } \\
\hline 1 & 71,39 & B & $65,80 \mathrm{~B}$ & 149,29 & B & 80,00 & $\mathbf{C}$ & 77,50 & $\mathbf{A}$ & 14,58 & D \\
\hline 2 & 69,47 & B & $52,16 \mathrm{C}$ & 144,52 & B & 59,16 & D & 75,05 & $\mathbf{A}$ & 7,77 & D \\
\hline 3 & 68,64 & B & 66,52 B & 136,83 & C & 86,10 & $\mathbf{C}$ & 67,34 & B & 19,58 & C \\
\hline 4 & 68,44 & B & 72,75 B & 154,69 & $\mathbf{A}$ & 90,71 & B & 86,28 & $\mathbf{A}$ & 17,96 & C \\
\hline 5 & 75,63 & B & 72,04 B & 157,92 & $\mathbf{A}$ & 81,17 & C & 82,29 & $\mathbf{A}$ & 9,42 & D \\
\hline 6 & 75,82 & B & $92,83 \mathrm{~A}$ & 156,35 & $\mathbf{A}$ & 110,92 & $\mathbf{A}$ & 80,53 & $\mathbf{A}$ & 17,27 & C \\
\hline 7 & 73,75 & B & $66,78 \mathrm{~B}$ & 154,42 & $\mathbf{A}$ & 81,95 & C & 80,67 & $\mathbf{A}$ & 16,84 & C \\
\hline 8 & 68,14 & B & $61,58 \mathrm{C}$ & 151,13 & B & 67,84 & D & 82,99 & $\mathbf{A}$ & 7,44 & D \\
\hline 9 & 57,03 & $\mathbf{A}$ & $40,11 \mathrm{D}$ & 123,98 & D & 44,76 & D & 66,23 & B & 5,61 & D \\
\hline 10 & 72,08 & B & $66,16 \mathrm{~B}$ & 159,88 & $\mathbf{A}$ & 108,90 & $\mathbf{A}$ & 79,22 & A & 48,14 & $\mathbf{A}$ \\
\hline 11 & 60,75 & $\mathbf{A}$ & $60,50 \mathrm{C}$ & 131,50 & D & 68,50 & D & 67,00 & B & 8,00 & D \\
\hline 12 & 73,65 & B & 70,77 B & 139,05 & C & 78,29 & C & 68,57 & B & 10,59 & D \\
\hline 13 & 75,10 & B & $53,87 \mathrm{C}$ & 148,27 & B & 67,37 & D & 73,17 & B & 13,50 & D \\
\hline 14 & 66,55 & B & $60,11 \mathrm{C}$ & 125,67 & D & 69,01 & D & 59,12 & B & 10,10 & D \\
\hline 15 & 58,64 & $\mathbf{A}$ & $57,05 \mathrm{C}$ & 129,41 & D & 63,34 & D & 70,49 & B & 7,31 & D \\
\hline 16 & 66,11 & B & $58,57 \mathrm{C}$ & 142,12 & C & 68,21 & D & 76,01 & $\mathbf{A}$ & 9,82 & D \\
\hline 17 & 71,61 & B & $85,58 \mathrm{~A}$ & 148,87 & B & 112,54 & $\mathbf{A}$ & 77,26 & $\mathbf{A}$ & 26,40 & B \\
\hline 18 & 67,66 & B & $54,20 \mathrm{C}$ & 134,53 & C & 62,66 & D & 66,87 & B & 8,62 & D \\
\hline 19 & 74,29 & B & 79,53 A & 155,14 & $\mathbf{A}$ & 108,83 & $\mathbf{A}$ & 81,55 & $\mathbf{A}$ & 28,83 & B \\
\hline 20 & 66,37 & B & 47,35 D & 140,91 & C & 54,61 & D & 74,54 & $\mathbf{A}$ & 8,43 & D \\
\hline 21 & 64,68 & B & $60,35 \mathrm{C}$ & 133,89 & C & 67,24 & D & 69,62 & B & 8,07 & D \\
\hline 22 & 58,66 & A & $44,83 \mathrm{D}$ & 123,45 & D & 49,74 & D & 66,29 & B & 10,39 & D \\
\hline 23 & 76,70 & $\mathbf{C}$ & $73,28 \mathrm{~B}$ & 155,31 & $\mathbf{A}$ & 93,26 & B & 78,60 & $\mathbf{A}$ & 21,07 & C \\
\hline 24 & 73,34 & B & $84,31 \mathrm{~A}$ & 154,28 & $\mathbf{A}$ & 104,72 & $\mathbf{A}$ & 80,49 & A & 20,16 & C \\
\hline 25 & 77,70 & C & $68,86 \mathrm{~B}$ & 154,52 & $\mathbf{A}$ & 77,74 & C & 76,82 & $\mathbf{A}$ & 10,17 & D \\
\hline 26 & 68,73 & B & $44,05 \mathrm{D}$ & 145,50 & B & 49,56 & D & 76,77 & $\mathbf{A}$ & 6,26 & D \\
\hline 27 & 61,17 & A & $47,80 \mathrm{D}$ & 144,52 & B & 57,26 & D & 81,92 & A & 8,89 & D \\
\hline 28 & 71,76 & B & $56,68 \mathrm{C}$ & 143,25 & B & 67,30 & D & 71,49 & B & 11,31 & D \\
\hline 29 & 78,49 & C & $71,51 \mathrm{~B}$ & 162,43 & $\mathbf{A}$ & 94,63 & B & 83,94 & $\mathbf{A}$ & 23,13 & B \\
\hline 30 & 71,86 & B & $65,07 \mathrm{~B}$ & 151,52 & B & 78,57 & C & 76,89 & $\mathbf{A}$ & 16,94 & C \\
\hline 31 & 74,70 & B & $55,61 \mathrm{C}$ & 157,86 & $\mathbf{A}$ & 64,86 & D & 83,47 & $\mathbf{A}$ & 11,23 & D \\
\hline 32 & 71,58 & B & 66,49 В & 146,17 & B & 79,29 & C & 73,69 & B & 13,08 & D \\
\hline 33 & 66,58 & B & $57,67 \mathrm{C}$ & 135,26 & C & 66,22 & D & 69,70 & B & 9,78 & D \\
\hline
\end{tabular}

1. Médias não transformadas de até 36 plantas para as progênies (9 covas/repetição x 2 ambientes) e de até 72 plantas para as testemunhas ( 9 covas/repetição $\times 2$ repetições $\times$ e conjuntos $\times 2$ ambientes)

2. Médias seguidas de mesma letra não diferem pelo método de grupamento de Scott-Knott a 5\% de significâncica.

3. Progênies identificadas na Tabela 5.

4. Caracteres identificados no Apêndice 3. 
Tabela 17. Médias ${ }^{1}$ (m) e classificações ${ }^{2}$ (SK). (continuação). Médias e classificações (SK) pelo teste de Scott-Knott das 33 progênies ${ }^{3}$ e quatro testemunhas avaliadas com base na média de repetições para os 18 caracteres avaliados ${ }^{4}$ para os dois locais. Soja: Anhembi, semeadura em 24/11/1998; ESALQ, semeadura 09/11/1998.

\begin{tabular}{|c|c|c|c|c|c|c|c|c|c|c|c|c|}
\hline \multirow[t]{2}{*}{ Caracteres } & \multicolumn{2}{|c|}{ AC } & \multicolumn{2}{|c|}{ VA } & \multicolumn{2}{|c|}{ LVV } & \multicolumn{2}{|l|}{ PG } & \multicolumn{2}{|l|}{ PCS } & \multicolumn{2}{|c|}{$\% \mathrm{OL}$} \\
\hline & m & $\overline{\mathrm{SK}}$ & $\mathbf{m}$ & SK & $\mathbf{m}$ & SK & $\mathbf{m}$ & SK & m & SK & $\mathbf{m}$ & SK \\
\hline \multicolumn{13}{|l|}{ Testemunhas } \\
\hline Céu Azul & 1,87 & $\mathbf{A}$ & 2,88 & $\mathbf{A}$ & 2,85 & $\mathbf{A}$ & 134,79 & $\mathbf{A}$ & 22,72 & B & 19,76 & $\mathbf{A}$ \\
\hline IAC PL-1 & 1,38 & $\mathbf{A}$ & 2,59 & B & 3,16 & $\mathbf{A}$ & 137,96 & $\mathbf{A}$ & 24,48 & $\mathbf{A}$ & 19,84 & $\mathbf{A}$ \\
\hline Tamba & 1,83 & $\mathbf{A}$ & 2,93 & $\mathbf{A}$ & 3,55 & $\mathbf{A}$ & 110,76 & B & 27,07 & $\mathbf{A}$ & 17,08 & C \\
\hline Nimame & 2,13 & $\mathbf{A}$ & 2,68 & B & 2,02 & B & 91,04 & B & 17,25 & D & 19,59 & $\mathbf{A}$ \\
\hline \multicolumn{13}{|l|}{ Progênies } \\
\hline 1 & 1,55 & $\mathbf{A}$ & 2,36 & B & 2,55 & B & 67,68 & B & 21,15 & B & 16,73 & C \\
\hline 2 & 1,41 & $\mathbf{A}$ & 2,46 & B & 2,68 & B & 139,81 & $\mathbf{A}$ & 22,98 & B & 20,69 & A \\
\hline 3 & 2,12 & $\mathbf{A}$ & 2,77 & B & 3,26 & $\mathbf{A}$ & 127,77 & $\mathbf{A}$ & 24,35 . & $\mathbf{A}$ & 18,90 & B \\
\hline 4 & 2,14 & $\mathbf{A}$ & 3,12 & $\mathbf{A}$ & 3,01 & $\mathbf{A}$ & 86,27 & B & 23,09 & B & 16,51 & C \\
\hline 5 & 1,56 & $\mathbf{A}$ & 3,15 & $\mathbf{A}$ & 3,03 & A & 130,47 & $\mathbf{A}$ & 23,84 & $\mathbf{A}$ & 18,16 & B \\
\hline 6 & 2,36 & $\mathbf{A}$ & 2,73 & B & 2,50 & B & 122,13 & $\mathbf{A}$ & 20,60 & C & 18,18 & B \\
\hline 7 & 1,57 & $\mathbf{A}$ & 3,15 & $\mathbf{A}$ & 2,31 & B & 122,76 & $\mathbf{A}$ & 18,79 & C & 17,37 & C \\
\hline 8 & 1,90 & $\mathbf{A}$ & 2,49 & B & 2,23 & C & 108,16 & B & 19,23 & C & 19,99 & A \\
\hline 9 & 1,32 & $\mathbf{A}$ & 2,16 & B & 2,90 & $\mathbf{A}$ & 100,08 & B & 23,50 & $\mathbf{A}$ & 20,90 & $\mathbf{A}$ \\
\hline 10 & 1,90 & $\mathbf{A}$ & 2,94 & $\mathbf{A}$ & 3,11 & $\mathbf{A}$ & 109,52 & B & 23,50 & $\mathbf{A}$ & 19,14 & $\mathbf{A}$ \\
\hline 11 & 1,83 & $\mathbf{A}$ & 2,83 & $\mathbf{A}$ & 2,42 & B & 126,52 & $\mathbf{A}$ & 22,92 & B & 19,99 & A \\
\hline 12 & 1,91 & A & 2,75 & B & 3,06 & $\mathbf{A}$ & 167,87 & $\mathbf{A}$ & 24,31 & $\mathbf{A}$ & 20,19 & A \\
\hline 13 & 2,50 & $\mathbf{A}$ & 3,25 & $\mathbf{A}$ & 2,95 & $\mathbf{A}$ & 177,91 & $\mathbf{A}$ & 22,33 & B & 20,32 & A \\
\hline 14 & 1,97 & $\mathbf{A}$ & 2,84 & $\mathbf{A}$ & 1,62 & C & 131,88 & $\mathbf{A}$ & 15,22 & D & 20,67 & $\mathbf{A}$ \\
\hline 15 & 1,80 & $\mathbf{A}$ & 2,67 & B & 2,88 & $\mathbf{A}$ & 86,89 & B & 23,95 & $\mathbf{A}$ & 18,53 & B \\
\hline 16 & 1,96 & $\mathbf{A}$ & 3,07 & $\mathbf{A}$ & 3,22 & $\mathbf{A}$ & 156,41 & $\mathbf{A}$ & 24,73 & $\mathbf{A}$ & 19,85 & $\mathbf{A}$ \\
\hline 17 & 2,56 & $\mathbf{A}$ & 3,11 & A & 2,70 & B & 174,13 & $\mathbf{A}$ & 21,50 & B & 20,81 & $\mathbf{A}$ \\
\hline 18 & 1,84 & $\mathbf{A}$ & 3,34 & $\mathbf{A}$ & 3,09 & $\mathbf{A}$ & 111,10 & B & 24,11 & $\mathbf{A}$ & 20,45 & $\mathbf{A}$ \\
\hline 19 & 2,20 & $\mathbf{A}$ & 3,28 & $\mathbf{A}$ & 3,41 & $\mathbf{A}$ & 139,66 & $\mathbf{A}$ & 25,60 & $\mathbf{A}$ & 18,69 & B \\
\hline 20 & 1,75 & $\mathbf{A}$ & 2,57 & B & 3,25 & $\mathbf{A}$ & 122,32 & $\mathbf{A}$ & 23,99 & $\mathbf{A}$ & 19,46 & $\mathbf{A}$ \\
\hline 21 & 2,02 & $\mathbf{A}$ & 2,77 & B & 3,24 & $\mathbf{A}$ & 112,67 & B & 24,36 & $\mathbf{A}$ & 20,11 & A \\
\hline 22 & 2,25 & $\mathbf{A}$ & 2,57 & B & 3,10 & $\mathbf{A}$ & 108,38 & B & 23,71 & $\mathbf{A}$ & 21,23 & $\mathbf{A}$ \\
\hline 23 & 2,12 & $\mathbf{A}$ & 3,27 & A & 2,82 & $\mathbf{A}$ & 149,16 & $\mathbf{A}$ & 21,96 & B & 18,57 & B \\
\hline 24 & 2,58 & $\mathbf{A}$ & 2,88 & A & 2,75 & B & 160,62 & $\mathbf{A}$ & 22,43 & B & 19,46 & A \\
\hline 25 & 1,73 & $\mathbf{A}$ & 2,74 & B & 2,68 & $\mathbf{B}$ & 139,89 & $\mathbf{A}$ & 21,58 & B & 18,59 & B \\
\hline 26 & 1,14 & $\mathbf{A}$ & 2,13 & B & 1,90 & C & 108,59 & B & 17,11 & D & 18,85 & B \\
\hline 27 & 1,40 & $\mathbf{A}$ & 2,44 & B & 2,85 & $\mathbf{A}$ & 89,57 & B & 21,78 & B & 17,14 & C \\
\hline 28 & 1,87 & $\mathbf{A}$ & 2,94 & A & 2,12 & C & 130,35 & $\mathbf{A}$ & 18,61 & $\mathbf{C}$ & 18,32 & B \\
\hline 29 & 2,26 & $\mathbf{A}$ & 3,41 & $\mathbf{A}$ & 2,67 & B & 98,81 & B & 22,55 & B & 16,94 & C \\
\hline 30 & 1,96 & $\mathbf{A}$ & 2,95 & $\mathbf{A}$ & 3,26 & $\mathbf{A}$ & 116,36 & B & 24,65 & $\mathbf{A}$ & 19,49 & $\mathbf{A}$ \\
\hline 31 & 1,91 & $\mathbf{A}$ & 2,89 & A & 2,65 & B & 127,20 & A & 21,77 & B & 18,85 & B \\
\hline 32 & 1,58 & $\mathbf{A}$ & 3,01 & $\mathbf{A}$ & 2,54 & B & 107,54 & B & 20,14 & C & 19,62 & $\mathbf{A}$ \\
\hline 33 & 1,54 & $\mathbf{A}$ & 2,83 & A & 2,65 & B & 121,37 & $\mathbf{A}$ & 20,89 & B & 20,01 & A \\
\hline
\end{tabular}

1. Médias não transformadas de até 36 plantas para as progênies $(9$ covas/repetiçáo $\times 2$ ambientes) e de até 72 plantas para as testemunhas ( 9 covas/repetição $\times 2$ repetiç̃es $x$ e conjuntos $\times 2$ ambientes)

2. Médias seguidas de mesma letra não diferem pelo método de grupamento de Scott-Knott a $5 \%$ de significâncica.

3. Progênies identificadas na Tabela 5.

4. Caracteres identificados no Apêndice 3.

(continua) 
Tabela 17. Médias ${ }^{1}$ (m) e classificaçōes ${ }^{2}$ (SK). (continuação). Médias e classificações (SK) pelo teste de Scott-Knott das 33 progênies ${ }^{3}$ e quatro testemunhas avaliadas com base na média de repetições para os 18 caracteres avaliados ${ }^{4}$ para os dois locais. Soja: Anhembi, semeadura em 24/11/1998; ESALQ, semeadura 09/11/1998.

\begin{tabular}{|c|c|c|c|c|c|c|c|c|c|c|c|c|}
\hline \multirow[t]{2}{*}{ Caracteres } & \multicolumn{2}{|c|}{ PO } & \multicolumn{2}{|c|}{ NTV } & \multicolumn{2}{|c|}{$\% \mathrm{~V} 1$} & \multicolumn{2}{|c|}{$\% \mathrm{~V} 2$} & \multicolumn{2}{|c|}{ \%V3 } & \multicolumn{2}{|l|}{ PV } \\
\hline & $\mathbf{m}$ & SK & m & SK & $\mathbf{m}$ & SK & $\mathbf{m}$ & SK & $\mathbf{m}$ & $\overline{\mathbf{S K}}$ & $\mathbf{m}$ & SK \\
\hline \multicolumn{13}{|l|}{ Testemunhas } \\
\hline Céu Azul & 27,18 & B & 345,19 & B & 13,50 & B & 69,29 & $\mathbf{A}$ & 15,56 & $\mathbf{C}$ & 245,45 & $\mathbf{A}$ \\
\hline IAC PL-1 & 27,88 & B & 355,27 & B & 17,81 & B & 66,94 & $\mathbf{A}$ & 15,24 & C & 236,05 & $\mathbf{A}$ \\
\hline Tamba & 18,76 & B & 363,80 & $\mathbf{A}$ & 40,46 & $\mathbf{A}$ & 55,02 & B & 4,51 & C & 212,28 & B \\
\hline Nimame & 18,17 & B & 367,70 & A & 19,23 & $\mathbf{A}$ & 66,93 & $\mathbf{A}$ & 13,84 & $\mathbf{C}$ & 176,15 & B \\
\hline \multicolumn{13}{|l|}{ Progênies } \\
\hline 1 & 10,57 & B & 179,17 & B & 18,61 & $\mathbf{A}$ & 64,11 & B & 17,28 & C & 113,04 & B \\
\hline 2 & 29,07 & B & 380,56 & $\mathbf{A}$ & 13,38 & B & 70,50 & $\mathbf{A}$ & 16,13 & $\mathbf{C}$ & 229,38 & $\mathbf{A}$ \\
\hline 3 & 24,68 & B & 302,48 & B & 18,07 & $\mathbf{A}$ & 66,49 & $\mathbf{A}$ & 16,06 & C & 200,61 & B \\
\hline 4 & 14,45 & B & 225,78 & B & 14,75 & B & 59,30 & B & 25,95 & B & 154,89 & B \\
\hline 5 & 23,94 & B & 380,25 & $\mathbf{A}$ & 16,37 & B & 64,58 & $\mathbf{B}$ & 18,56 & B & 247,08 & $\mathbf{A}$ \\
\hline 6 & 23,53 & B & 301,00 & B & 20,38 & $\mathbf{A}$ & 63,26 & $\mathbf{B}$ & 16,36 & C & 167,49 & B \\
\hline 7 & 21,76 & B & 365,03 & $\mathbf{A}$ & 36,51 & $\mathbf{A}$ & 56,24 & B & 7,25 & C & 194,00 & B \\
\hline 8 & 22,31 & B & 325,48 & B & 16,72 & B & 64,81 & B & 18,47 & B & 166,68 & B \\
\hline 9 & 20,90 & B & 201,98 & B & 23,57 & $\mathbf{A}$ & 58,91 & B & 17,52 & C & 214,01 & B \\
\hline 10 & 20,44 & B & 345,44 & B & 21,13 & $\mathbf{A}$ & 57,45 & B & 22,05 & B & 208,61 & B \\
\hline 11 & 25,48 & B & 448,00 & $\mathbf{A}$ & 11,25 & B & 43,00 & C & 45,75 & $\mathbf{A}$ & 212,74 & B \\
\hline 12 & 33,69 & $\mathbf{A}$ & 410,48 & $\mathbf{A}$ & 20,20 & $\mathbf{A}$ & 61,37 & B & 18,43 & B & 277,14 & $\mathbf{A}$ \\
\hline 13 & 36,65 & $\mathbf{A}$ & 572,50 & $\mathbf{A}$ & 12,23 & B & 79,30 & A & 8,48 & C & 287,96 & $\mathbf{A}$ \\
\hline 14. & 27,50 & B & 406,15 & $\mathbf{A}$ & 9,69 & B & 39,88 & C & 50,44 & $\mathbf{A}$ & 185,22 & B \\
\hline 15 & 16,01 & B & 179,75 & B & 12,55 & B & 72,88 & $\mathbf{A}$ & 14,58 & C & 165,82 & B \\
\hline 16 & 32,75 & $\mathbf{A}$ & 341,63 & B & 14,56 & B & 72,68 & $\mathbf{A}$ & 12,76 & C & 260,77 & A \\
\hline 17 & 36,44 & $\mathbf{A}$ & 517,60 & $\mathbf{A}$ & 17,14 & B & 68,87 & $\mathbf{A}$ & 13,99 & C & 301,09 & $\mathbf{A}$ \\
\hline 18 & 22,54 & B & 237,44 & B & 16,11 & B & 56,87 & B & 27,03 & B & 166,15 & B \\
\hline 19 & 26,61 & B & 330,88 & B & 22,43 & $\mathbf{A}$ & 55,79 & B & 21,66 & B & 224,36 & $\mathbf{A}$ \\
\hline 20 & 24,35 & B & 319,44 & B & 15,03 & B & 71,41 & $\mathbf{A}$ & 11,46 & C & 211,52 & B \\
\hline 21 & 22,98 & B & 300,85 & B & 21,49 & $\mathbf{A}$ & 61,65 & B & 16,86 & C & 197,71 & B \\
\hline 22 & 23,11 & B & 236,79 & B & 16,69 & B & 62,27 & $\mathbf{B}$ & 21,04 & B & 153,55 & B \\
\hline 23 & 27,82 & B & 428,30 & A & 16,07 & B & 56,87 & B & 27,06 & B & 243,10 & $\mathbf{A}$ \\
\hline 24 & 31,79 & $\mathbf{A}$ & 460,80 & $\mathbf{A}$ & 16,82 & B & 72,10 & $\mathbf{A}$ & 7,96 & C & 277,46 & $\mathbf{A}$ \\
\hline 25 & 25,94 & B & 368,98 & $\mathbf{A}$ & 13,96 & B & 63,56 & B & 23,93 & B & 232,93 & $\mathbf{A}$ \\
\hline 26 & 20,49 & B & 373,83 & $\mathbf{A}$ & 13,09 & B & 66,95 & $\mathbf{A}$ & 19,96 & B & 173,75 & B \\
\hline 27 & 15,54 & B & 268,62 & B & 18,11 & A & 58,63 & B & 23,26 & B & 159,36 & B \\
\hline 28 & 23,90 & B & 446,48 & A & 13,54 & B & 68,76 & $\mathbf{A}$ & 17,70 & C & 200,01 & B \\
\hline 29 & 17,27 & B & 331,56 & B & 24,14 & $\mathbf{A}$ & 64,32 & B & 11,55 & C & 175,80 & B \\
\hline 30 & 22,98 & B & 300,58 & B & 10,52 & B & 65,67 & $\mathbf{A}$ & 23,81 & B & 198,76 & B \\
\hline 31 & 23,92 & B & 387,67 & $\mathbf{A}$ & 20,71 & $\mathbf{A}$ & 67,88 & $\mathbf{A}$ & 11,42 & C & 199,01 & B \\
\hline 32 & 21,07 & B & 349,85 & B & 13,88 & B & 63,29 & B & 22,83 & B & 177,38 & B \\
\hline 33 & 24,19 & B & 349,38 & B & 16,00 & B & 62,09 & B & 21,91 & B & 203,09 & B \\
\hline
\end{tabular}

1. Médias não transformadas de até 36 plantas para as progênies ( 9 covas/repetição $\times 2$ ambientes) e de até 72 plantas para as testemunhas ( 9 covas/repetição $\times 2$ repetições $\times$ e conjuntos $\times 2$ ambientes)

2. Médias seguidas de mesma letra não diferem pelo método de grupamento de Scott-Knott a $5 \%$ de significancica.

3. Progênies identificadas na Tabela 5.

4. Caracteres identificados no Apêndice 3. 
Tabela 18. Correlações Fenotípicas - Testemunhas. Correlações fenotípicas em porcentagem entre os caracteres período reprodutivo (PR), largura visual de vagens (LVV), peso de cem sementes (PCS), porcentagem de óleo (\%OL), número total de vagens (NTV), porcentagem de vagens com 1 semente $(\% \mathrm{~V} 1)$, porcentagem de vagens com 2 sementes (\%V2), porcentagem de vagens com 3 ou mais vagens $(\% \mathrm{~V} 3)$ e peso de vagens $(\mathrm{PV})$ ao nível de parcelas experimentais, dentro do grupo das quatro testemunhas para cada local e para os dois locais em conjunto. Soja: Anhembi, semeadura em 24/11/1998; ESALQ, semeadura 09/11/1998.

\begin{tabular}{|c|c|c|c|c|c|c|c|c|c|c|}
\hline Caracteres & & LVV & $\mathrm{PG}^{\mathrm{t}}$ & $\mathrm{PCS}^{2}$ & $\% \mathrm{OL}^{\mathrm{T}}$ & NTV & $\overline{\% V I}^{i-}$ & $\% \overline{2} 2^{-}$ & $\%$ V3 & PV \\
\hline \multirow[t]{3}{*}{$\overrightarrow{P R}^{i}$} & Anhembi & $80,75^{* *}$ & 32,65 & $84,21 * *$ & $-67,52 * *$ & $-9,27$ & $70,00 * *$ & $-77,99^{* *}$ & $-48,79$ & 30,99 \\
\hline & ESALQ & $89,18 * *$ & $-1,01$ & $85,07 * *$ & $-67,92 * *$ & 9,64 & $79,87 * *$ & $-59,30 *$ & $-75,33 * *$ & 2,52 \\
\hline & 2 locais & $82,24 * *$ & 0,06 & $81,96^{* *}$ & $-67,70 * *$ & $-6,28$ & 70,77 ** & $-53,89 * *$ & $-60,34 * *$ & 7,46 \\
\hline \multirow[t]{3}{*}{ LVV } & Anhembi & & $53,70 *$ & $98,92 * *$ & $-46,39$ & $-36,55$ & 35,96 & $-52,96 *$ & $-15,57$ & 27,35 \\
\hline & ESALQ & & 26,45 & $92,50 * *$ & $-47,64$ & 22,91 & 68,45 & $-45,09$ & $-64,75 * *$ & 26,30 \\
\hline & 2 locais & & 30,70 & $95,22 * *$ & $-46,88 * *$ & $-6,94$ & $47,71 * *$ & $-43,73 *$ & $-31,88$ & 23,10 \\
\hline \multirow[t]{3}{*}{$P^{t}$} & Anhembi & & & $56,06 *$ & 19,76 & $-10,54$ & $-34,09$ & 7,42 & 46,14 & 47,99 \\
\hline & ESALQ & & & 17,05 & $50,88 *$ & 45,32 & $-14,58$ & 34,69 & $-15,68$ & $90,81 * *$ \\
\hline & 2 locais & & & 30,06 & $37,60 *$ & $39,32 *$ & $-20,48$ & 2,60 & 30,78 & $74,98 * *$ \\
\hline \multirow[t]{3}{*}{$\mathrm{PCS}^{t}$} & Anhembi & & & & $-46,04$ & $-29,71$ & 36,90 & $-54,24 *$ & $-15,95$ & 32,18 \\
\hline & ESALQ & & & & $-51,92 * *$ & 7,97 & $57,78 * *$ & $-45,45$ & $-59,19 *$ & 18,75 \\
\hline & 2 locais & & & & $-48,67 *$ & $-6,48$ & $45,36 *$ & $-47,11 * *$ & $-29,12$ & 24,44 \\
\hline \multirow[t]{3}{*}{$\% \mathrm{OL}^{\mathrm{t}}$} & Anhembi & & & & & 10,83 & $-80,32 * *$ & $84,34 * *$ & $60,92 *$ & 21,94 \\
\hline & ESALQ & & & & & 7,97 & $-67,41 * *$ & $75,78 * *$ & 41,96 & 43,78 \\
\hline & 2 locais & & & & & 23,74 & $-73,49 * *$ & $71,30 * *$ & $51,68 * *$ & 34,33 \\
\hline \multirow[t]{3}{*}{ NTV } & Anhembi & & & & & & $-10,77$ & 5,64 & 12,63 & 16,94 \\
\hline & ESALQ & & & & & & 30,83 & $-7,50$ & $-16,80$ & 48,58 \\
\hline & 2 locais & & & & & & 10,00 & $-14,93$ & 13,18 & $42,73 *$ \\
\hline \multirow[t]{3}{*}{$\% \mathrm{~V}^{\mathrm{t}}$} & Anhembi & & & & & & & $-85,38 * *$ & $-89,90 * *$ & $-5,66$ \\
\hline & ESALQ & & & & & & & $-79,16 * *$ & $-58,25 *$ & $-4,29$ \\
\hline & 2 locais & & & $=$ & & & & $-77,49 * *$ & $-73,32 * *$ & $-4,60$ \\
\hline \multirow[t]{3}{*}{$\% \mathrm{~V} 2^{t}$} & Anhembi & & & & & & & & $54,74^{*}$ & $-13,72$ \\
\hline & ESALQ & & & & & & & & 13,59 & 23,89 \\
\hline & 2 locais & & & & & & & & 20,70 & $-6,57$ \\
\hline \multirow[t]{3}{*}{$\% \mathrm{~V} 3$} & Anhembi & & & & & & & & & 21,45 \\
\hline & ESALQ & & & & & & . & & & $-12,82$ \\
\hline & 2 locais & & & & & & & & & 18,29 \\
\hline
\end{tabular}

t: transformações identificados no Apêndice 3

1 : caracteres identificados no apêndice 3.

* e** : significativos a $5 \%$ e $1 \%$, respectivamente. 
Tabela 19. Correlações Fenotípicas - Progênies. Correlações fenotípicas em porcentagem entre os caracteres período reprodutivo (PR), largura visual de vagens (LVV), peso de cem sementes (PCS), porcentagem de óleo (\%OL), número total de vagens (NTV), porcentagem de vagens com 1 semente $(\% \mathrm{~V} 1)$, porcentagem de vagens com 2 sementes (\%V2), porcentagem de vagens com 3 ou mais vagens (\%V3) e peso de vagens (PV) ao nível de parcelas experimentais, dentro do grupo das 33 progênies para cada local e para os dois locais em conjunto. Soja: Anhembi, semeadura em 24/11/1998; ESALQ, semeadura 09/11/1998.

\begin{tabular}{|c|c|c|c|c|c|c|c|c|c|c|}
\hline Caracteres & & LVV & $\mathrm{P} \bar{G}^{\prime}$ & $\mathrm{PCS}^{\mathrm{i}}$ & $\% \mathrm{OL}^{t}$ & NTV & $\% \mathrm{V1}^{\mathrm{t}}$ & $\% 2^{\mathrm{i}}$ & \%V3 & PV \\
\hline \multirow[t]{3}{*}{$\overrightarrow{\mathbf{P R}^{\mathrm{I}}}$} & Anhembi & 16,21 & 4,40 & 14,89 & $-51,53 * *$ & $-0,86$ & $27,24^{*}$ & 11,69 & $-38,58 * *$ & 18,28 \\
\hline & ESALQ & 8,21 & $-19,10$ & 0,59 & $-50,45 * *$ & 7,17 & 19,64 & 14,42 & $-29,09 *$ & $-5,89$ \\
\hline & 2 locais & 14,33 & $-19,39 *$ & 7,24 & $-50,89 * *$ & $-0,96$ & $20,25 *$ & $18,63 *$ & $-35,87 * *$ & $-2,68$ \\
\hline \multirow[t]{3}{*}{ LVV } & Anhembi & & 20,73 & $95,54 * *$ & 9,51 & $-19,95$ & 15,76 & $25,41 *$ & $-38,57 * *$ & $21,09 *$ \\
\hline & ESALQ & & 0,17 & $82,86^{* *}$ & 6,17 & $-20,59$ & 13,43 & 12,05 & $-18,99$ & 15,06 \\
\hline & 2 locais & & 2,74 & $89,23 * *$ & 6,61 & $-22,10^{*}$ & 13,89 & $21,36 *$ & $-31,06 * *$ & 14,62 \\
\hline \multirow[t]{3}{*}{$P^{t}$} & Anhembi & & & 20,20 & $32,44 * *$ & $73,07^{* *}$ & 7,18 & 20,50 & $-22,35$ & $85,42 * *$ \\
\hline & ESALQ & & & $-2,76$ & $54,15 * *$ & $77,38 * *$ & $-19,05$ & 11,33 & 3,44 & 76,60 ** \\
\hline & 2 locais & & & 6,00 & $43,04^{* *}$ & $74,90 * *$ & $-1,50$ & 1,53 & 1,41 & $79,18 * *$ \\
\hline \multirow[t]{3}{*}{$\mathrm{PCS}^{\mathrm{t}}$} & Anhembi & & & & 9,12 & $-17,99$ & 4,75 & $39,43 * *$ & $-42,12 * *$ & 21,17 \\
\hline & ESALQ & & & & 7,52 & $-27,48 *$ & 19,72 & 3,92 & $-13,36$ & 5,97 \\
\hline & 2 locais & & & & 7,99 & $-22,80 * *$ & 10,63 & $21,60 *$ & $-28,23 * *$ & 12,54 \\
\hline \multirow[t]{3}{*}{$\% \mathrm{OL}^{\mathrm{t}}$} & Anhembi & & - & & & $33,01 * *$ & $-14,11$ & 4,55 & 10,95 & 24,25 \\
\hline & ESALQ & & & & & 14,88 & $-0,95$ & 0,08 & 8,63 & $42,80^{* *}$ \\
\hline & 2 locais & & & & & $24,13 * *$ & $-11,16$ & $-0,49$ & 11,41 & 36,41 ** \\
\hline \multirow[t]{3}{*}{ NTV } & Anhembi & & & & & & $-12,81$ & 13,10 & 2,88 & $81,87 * *$ \\
\hline & ESALQ & & & & & & $-14,30$ & 23,68 & $-8,83$ & $61,18^{* *}$ \\
\hline & 2 locais & & & & & & $-11,74$ & 12,81 & 0,67 & $70,77 * *$ \\
\hline \multirow[t]{3}{*}{$\% \mathrm{VI}{ }^{t}$} & Anhembi & & & & & & & $-39,43 * *$ & $-51,46 * *$ & 15,49 \\
\hline & ESALQ & & & & & & & $-26,49 *$ & $-61,24 *$ & 15,52 \\
\hline & 2 locais & & & & & & & $-33,49 * *$ & $-40,45^{* *}$ & 15,27 \\
\hline \multirow[t]{3}{*}{$\% \mathrm{~V} 2^{t}$} & Anhembi & & & & & & & & $-57,45 * *$ & 22,25 \\
\hline & ESALQ & & & & & & & & $-80,38 * *$ & 4,49 \\
\hline & 2 locais & & & & & & & & $-70,61 * *$ & 6,05 \\
\hline \multirow[t]{3}{*}{$\% \mathrm{~V} 3$} & Anhembi & & & & & & & & & $-28,16 *$ \\
\hline & ESALQ & & & & & & & & & $-10,96$ \\
\hline & 2 locais & & & & & & & & & $-12,99$ \\
\hline
\end{tabular}

t: transformaçôes identificados no Apêndice 3

1 : caracteres identificados no apêndice 3.

* $e^{* *}$ : significativos a $5 \%$ e $1 \%$, respectivamente. 
Tabela 20. Correlações Genotipícas. Correlações genotípica em porcentagem entre os caracteres período reprodutivo (PR), largura visual de vagens (LVV), peso de cem sementes (PCS), porcentagem de óleo (\%OL), número total de vagens (NTV), porcentagem de vagens com 1 semente $(\% \mathrm{~V} 1)$, porcentagem de vagens com 2 sementes (\%V2), porcentagem de vagens com 3 ou mais vagens (\%V3) e peso de vagens (PV) ao nível de parcelas experimentais, dentro do grupo das progênies para os dois locais. Soja: Anhembi, semeadura em 24/11/1998; ESALQ, semeadura 09/11/1998.

\begin{tabular}{|c|c|c|c|c|c|c|c|c|c|}
\hline Caracteres & LVV & $\overline{P G^{t}}$ & $\overline{\text { PCS }^{t}}$ & $\% \mathrm{OL}^{\mathrm{t}}$ & NTV & $\% \mathrm{V1}^{\mathrm{t}}$ & $\% \mathrm{~V} 2^{t}$ & $\% \mathrm{~V} 3$ & PV \\
\hline$\overline{P^{T}}$ & 7,28 & $>100$ & $-31,50$ & $-63,80$ & 8,69 & $<100$ & 5,65 & $-65,15$ & $-15,28$ \\
\hline LVV & & $-34,93$ & $>100$ & $-33,99$ & $<100$ & 59,99 & $<100$ & $-80,78$ & $<100$ \\
\hline$P^{t}$ & & & 26,05 & $>100$ & $<100$ & $-34,44$ & $>100$ & $-77,10$ & $>100$ \\
\hline $\mathrm{PCS}^{t}$ & & & & $-56,58$ & $<100$ & 27,82 & $<100$ & $-78,08$ & $<100$ \\
\hline$\% \mathrm{OL}^{\mathrm{t}}$ & & & & & $>100$ & $<100$ & 20,27 & 96,21 & $>100$ \\
\hline NTV & & & & & & $>100$ & $-10,95$ & $-1,03$ & 61,22 \\
\hline$\% V 1^{t}$ & & & & & & & $>100$ & $-47,67$ & $>100$ \\
\hline$\% V 2^{t}$ & & & & & & & & $-83,05$ & 42,75 \\
\hline \%V3 & & & & & & & & & $-23,20$ \\
\hline
\end{tabular}

t: transformaçð̃es identificados no Apêndice 3

1 : caracteres identificados no apêndice 3. 
Tabela 21. Identificação de Genótipos. Identificação de cores (flor, tegumento da semente, hilo, vagem e pubescência) de cada genótipo. Soja: Anhembi, semeadura 24/11/1998; ESALQ, semeadura 09/11/1998.

\begin{tabular}{|c|c|c|c|c|c|}
\hline Caracteres & $\begin{array}{c}\text { Corda } \\
\text { Flor } \\
\end{array}$ & $\begin{array}{c}\begin{array}{c}\text { Cor do tegumento da } \\
\text { semente }\end{array} \\
\end{array}$ & $\begin{array}{c}\text { Cor do } \\
\text { hilo }\end{array}$ & $\begin{array}{l}\text { Cor da } \\
\text { Vagem }\end{array}$ & $\begin{array}{c}\text { Cor da } \\
\text { pubescência }\end{array}$ \\
\hline \multicolumn{6}{|l|}{ Testemunhas } \\
\hline Céu Azul & Roxa & Amarelo Fosco & Marrom & Cinza & Marrom \\
\hline IAC PL-1 & Roxa & Amarelo Fosco & Marrom & Cinza & Cinza \\
\hline Tamba & Roxa & Preto & Preto & Marrom & Marrom \\
\hline Nimame & Roxa & Amarelo Fosco & Marrom & Cinza & Cinza \\
\hline \multicolumn{6}{|l|}{ Progênies' } \\
\hline 1 & Branca & Amarelo & Marrom & Marrom & Marrom \\
\hline 2 & Roxa & Amarelo Fosco & Marrom & Cinza & Marrom \\
\hline 3 & Roxa & Verde Fosco & Preto & Marrom & Marrom \\
\hline 4 & Roxa & Verde Fosco & Preto & Marrom & Marrom \\
\hline 5 & Roxa & Amarelo Fosco & Creme & Cinza & Cinza \\
\hline 6 & Roxa & Amarelo Fosco & Preto & Marrom & Marrom \\
\hline 7 & Roxa & Amarelo Fosco & Marrom & Marrom & Marrom \\
\hline 8 & Roxa & Amarelo Fosco & Marrom & Marrom & Marrom \\
\hline 9 & Roxa & Preto Brilhante & Preto & Cinza & Cinza \\
\hline 10 & Branca & Amarelo Fosco & Preto & Cinza & Marrom \\
\hline 11 & Roxa & Amarelo esverdeado & Creme & Cinza & Marrom \\
\hline 12 & Roxa & Preto Fosco & Preto & Cinza & Marrom \\
\hline 13 & Branca & Preto Fosco & Preto & Cinza & Cinza \\
\hline 14 & Roxa & Verde Fosco & Preto & Cinza & Cinza \\
\hline 15 & Branca & Preto Fosco & Preto & Cinza & Marrom \\
\hline 16 & Roxa & Preto Fosco & Preto & Cinza & Marrom \\
\hline 17 & Roxa & Preto Brilhante & Preto & Cinza & Marrom \\
\hline 18 & Roxa & Verde Fosco & Preto & Marrom & Marrom \\
\hline 19 & Roxa & Verde Fosco & Preto & Marrom & Marrom \\
\hline 20 & Branca & Verde Fosco & Preto & Cinza & Cinza \\
\hline 21 & Roxa & Verde Fosco & Preto & Cinza & Marrom \\
\hline 22 & Roxa & Preto Brilhante & Preto & Marrom & Marrom \\
\hline 23 & Roxa & Preto Brilhante & Preto & Marrom & Marrom \\
\hline 24 & Roxa & Preto Fosco & Preto & Marrom & Marrom \\
\hline 25 & Roxa & Amarelo Fosco & Preto & Marrom & Marrom \\
\hline 26 & Branca & Armarelo Brilhante & Marrom & Cinza & Cinza \\
\hline 27 & Roxa & Amarelo Fosco & Preto & Cinza & Marrom \\
\hline 28 & Branca & Amarelo Fosco & Marrom & Cinza & Cinza \\
\hline 29 & Branca & Amarelo Fosco & Marrom & Marrom & Marrom \\
\hline 30 & Roxa & Amarelo Fosco & Marrom & Cinza & Marrom \\
\hline 31 & Roxa & Marrom Brilhante & Marrom & Marrom & Cinza \\
\hline 32 & Roxa & Amarelo Fosco & Marrom & Cinza & Marrom \\
\hline 33 & Roxa & Amarelo Fosco & Creme ou Marrom & Cinza & Cinza \\
\hline
\end{tabular}

1. Identificação das progênies na Tabela 
APÊNDICES 
Apêndice 1. Dados Climáticos - ESALQ. Médias e totais de insolação, precipitação, umidade relativa, vento máximo, vento médio, temperatura máxima, média e mínima da evaporação durante o período de permanência dos ensaios no campo. Soja. ESALQ, semeadura 09/11/1998.

\begin{tabular}{ccccccc}
\hline Insolação Precipi- Umidade & Vento & Vento & Temper. Temper. Temper. Evapo- \\
H/D & tação & Relativa & Máximo \\
$\mathrm{Mm}$ & $\%$ & $\mathrm{~m} / \mathrm{s}$ & $\begin{array}{c}\text { Médio } \\
\mathrm{Km} / \mathrm{h}\end{array}$ & $\begin{array}{c}\text { Máxima Minima } \\
{ }^{\circ} \mathrm{C}\end{array}{ }^{\circ} \mathrm{C}$ & $\begin{array}{c}\text { Média ração } \\
{ }^{\circ} \mathrm{C}\end{array}$ \\
\hline
\end{tabular}

Novembro/1998

$\begin{array}{rrrrrrrrrr}\text { Média } & 7,8 & 0,9 & 77 & 9,7 & 9,3 & 30,0 & 16,4 & 23,2 & 6,11 \\ \text { Total } & 233,8 & 26,6 & 2298 & 289,7 & 278,2 & 901,2 & 493,4 & 697,3 & 183,32\end{array}$

Dias de chuva:

5

Dezembro/1998

$\begin{array}{rrrrrrrrrr}\text { Média } & 6,1 & 9,4 & 82 & 8,7 & 6,3 & 30,0 & 19,2 & 24,6 & 5,91 \\ \text { Total } & 188,0 & 292,6 & 2545 & 268,7 & 195,0 & 930,2 & 595,4 & 762,8 & 183,22\end{array}$

Dias de chuva:

19

Janeiro/1999

$\begin{array}{rrrrrrrrrr}\text { Média } & 4,9 & 12,3 & 88 & 8,7 & 5,4 & 30,6 & 20,4 & 25,5 & 6,04\end{array}$

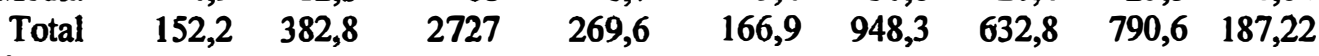

Dias de chuva:

21

Fevereiro/1999

\begin{tabular}{rrrrrrrrrr} 
Média & 5,4 & 7,1 & 90 & 8,7 & 5,6 & 30,7 & 20,1 & 25,4 & 5,29 \\
Total & 150,4 & 198,3 & 2520 & 244,3 & 158,0 & 860,4 & 561,5 & 711,0 & 148,04 \\
chuva: & 19 & & & & & & & & \\
\hline
\end{tabular}

Dias de chuva:

Março/1999

\begin{tabular}{rrrrrrrrrr} 
Média & 7,7 & 6,8 & 81 & 7,9 & 7,7 & 31,4 & 19,0 & 25,2 & 5,36 \\
$\begin{array}{r}\text { Total } \\
\text { chuva: }\end{array}$ & 238,8 & 210,8 & 2503 & 246,1 & 237,7 & 973,9 & 588,5 & 781,2 & 166,07 \\
\hline
\end{tabular}

Dias de chuva:

Abril/1999

\begin{tabular}{rrrrrrrrrr} 
Média & 8,1 & 3,0 & 81 & 7,9 & 7,0 & 28,5 & 15,2 & 21,9 & 4,21 \\
Total & 242,6 & 89,0 & 2421 & 237,4 & 211,4 & 855,7 & 456,1 & 655,9 & 126,33 \\
\hline
\end{tabular}

Dias de chuva:

Maio/1999

\begin{tabular}{rrrrrrrrrr} 
Média & 7,4 & 1,7 & 79 & 7,3 & 7,3 & 25,4 & 11,2 & 18,3 & 3,07 \\
Total & 230,8 & 51,3 & 2445 & 226,1 & 227,3 & 788,1 & 346,5 & 567,3 & 95,14 \\
\hline
\end{tabular}

Fonte: Estação climática da ESALQ - Piracicaba (dados 1998-1999). 
Apêndice 2 Escala de notas visuais aplicado sobre a largura visual das vagens (LVV) de soja.

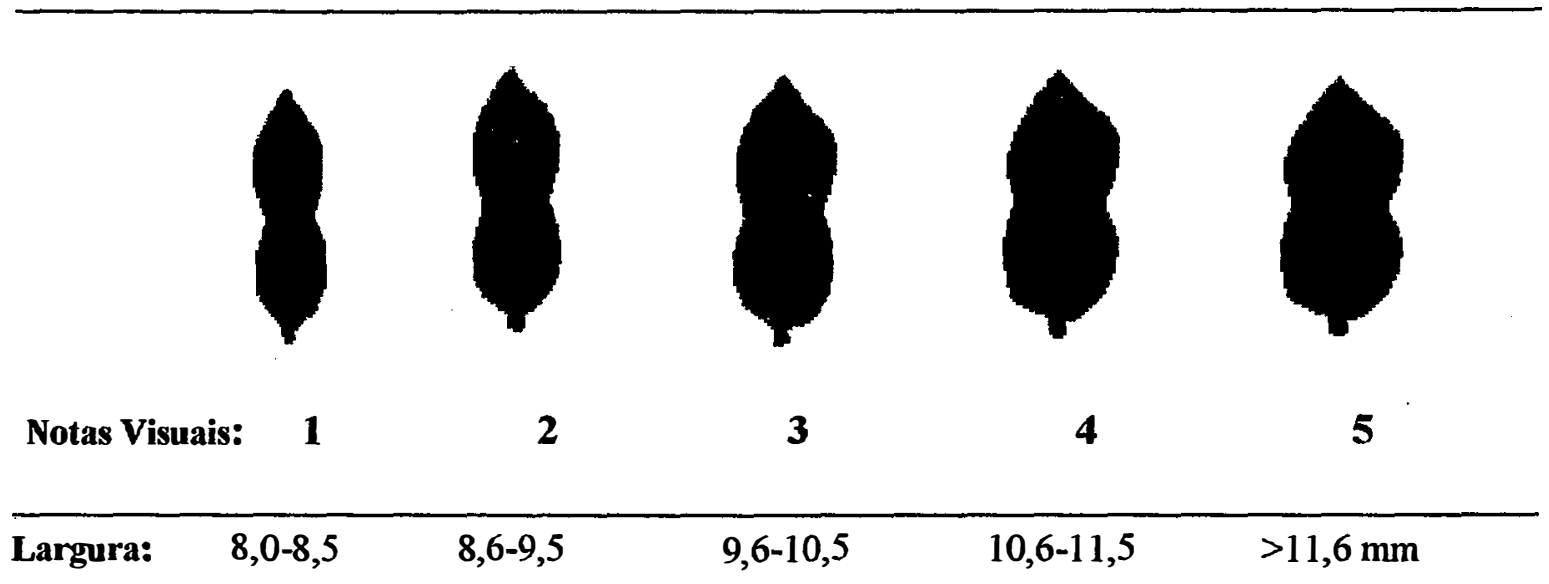

Fonte: Yokomizo \& Vello (1998). 
Apêndice 3. Identificação dos caracteres avaliados e respectivas transformações.

NDF - número de dias para o florescimento, transformado em $1 / \sqrt{x}$;

APF - altura da planta na maturidade, em centímetros;

NDM - número de dias para a maturidade;

APM - altura da planta na maturidade, em centímetros, transformado em $x^{2}$;

PR - período reprodutivo, transformado em $x^{1,4}$;

DAP - diferença na altura da planta durante o periodo reprodutivo, em centimetros, transformado em $x^{0,4}$;

AC - acamamento, avaliado por escala de notas visuais, variando de nota 1 (planta ereta) até 5 (planta totalmente deitada), transformada em $1 / \sqrt{x}$;

VA - valor agronômico, avaliado por escala de notas visuais variando de nota 1 (planta ruim) até 5 (planta ótima), transformada em $x^{1,3}$;

LVV - largura visual das vagens maduras, através de uma escala de notas, variando de nota 1 (vagens muito estreitas) até 5 (vagens muito largas);

PG - produtividade de grãos maduros, em gramas/planta, transformada em $\sqrt{x}$

PCS - peso de cem sementes maduras, em gramas/100 sementes, transformada em $x^{0,8}$

\%OL - teor de óleo (\%) nas sementes, transformada em $x^{2,5}$;

PO - produtividade de óleo, em gramas/planta, transformada em $x^{2,7}$;

NTV - número total de vagens maduras produzidas em plantas individuais;

$\% V 1$ - porcentagem de vagens maduras com uma semente produzida em plantas individuais, transformada em $\sqrt{x}$;

\%V2 - porcentagem de vagens maduras com duas sementes produzidas em plantas individuais, transformada em $x^{2}$;

\%V3 - porcentagem de vagens maduras com três ou mais sementes produzidas em plantas individuais;

PV - produtividade de vagens maduras, em gramas/planta. 